UNIVERSIDADE DE SÃO PAULO

FACULDADE DE FILOSOFIA, LETRAS E CIÊNCIAS HUMANAS

DEPARTAMENTO DE CIÊNCIA POLÍTICA

\title{
A DEMOCRACIA FEDERATIVA BRASILEIRA E O PAPEL DO SENADO NO AJUSTE FISCAL DOS ANOS 90
}

\section{Marcello Simão Branco}

Tese apresentada ao Programa de Pós-Graduação do Departamento de Ciência Política da Faculdade de Filosofia, Letras e Ciências Humanas da Universidade de São Paulo, para obtenção do título de Doutor em Ciência Política.

Orientador: Prof. Dr. Fernando Limongi 
UNIVERSIDADE DE SÃO PAULO

FACULDADE DE FILOSOFIA, LETRAS E CIÊNCIAS HUMANAS

DEPARTAMENTO DE CIÊNCIA POLÍTICA

\title{
A DEMOCRACIA FEDERATIVA BRASILEIRA E O PAPEL DO SENADO NO AJUSTE FISCAL DOS ANOS 90
}

\author{
Marcello Simão Branco
}


Aos meus pais Olivério e Luísa e em memória do Prof. Dr. Eduardo Kugelmas. 


\section{Agradecimentos}

Há um certo lugar-comum entre os estudantes de pós-graduação de que depois da obtenção do mestrado, o doutorado não seria tão difícil, pois já haveria sido obtida uma experiência básica sobre o processo de pesquisa e metodologia de um trabalho acadêmico. Não posso falar pelos demais, mas minha experiência não corrobora esta afirmação. Em primeiro lugar o doutorado é um trabalho maior e mais ambicioso, que exige mais dedicação (ainda) do que o mestrado. Em segundo lugar pesa sobre o doutorado os imprevistos do tempo do curso. Se quatro anos é um período suficiente para o trabalho, é longo o bastante para acontecer muitas coisas paralelas na vida pessoal do pesquisador. Realmente não dá para saber como um projeto como este vai terminar - se é que vai pois muitos fatos ocorrem, alguns capazes de mudar o rumo dos acontecimentos.

No meu caso particular, o principal deles foi a morte inesperada do meu orientador, o Prof. Dr. Eduardo Kugelmas, em novembro de 2006. Cultivava com ele uma relação de amizade e foi também uma perda intelectual significativa. A começar do fato de que me orientou no mestrado e o tema desta tese, por exemplo, ter sido sugestão sua. Os anos de convivência foram muito produtivos e acredito que este trabalho o deixaria satisfeito.

Agradeço primeiramente aos meus pais pela compreensão e apoio sobre esta opção de carreira, às vezes uma tanto estranha para eles, já que eu havia trilhado a de jornalista antes.

A seguir ao Prof. Dr. Fernando Limongi que assumiu a tarefa de minha orientação e em apenas dez meses mostrou-se interessado e sério no trabalho que fizemos, obrigando-me a me esforçar continuamente para torná-lo mais claro e robusto em seus métodos e argumentos. Agradeço-lhe tanto pela parte acadêmica, como pela disposição e apoio em um momento difícil desta caminhada.

O doutorado é o momento principal de uma trajetória iniciada na Faculdade de Filosofia, Letras e Ciências Humanas da USP, desde o início da graduação em Ciências Sociais em 1989. O ambiente intelectual sempre foi estimulante, a começar pela boa infra-estrutura, a exigência de parâmetros de qualidade e uma rica pluralidade de posições em busca do conhecimento, a quem devo minha própria formação como pesquisador. Em especial agradeço aos professores e funcionários do Departamento de Ciência Política, sempre acessíveis e prestativos, por permitir o meu acesso à pósgraduação e o aprimoramento de meus estudos. 
O Conselho Nacional de Desenvolvimento Científico e Tecnológico (CNPq) foi importante mais uma vez, pois financiou estes anos de jornada, sem os quais teria sido impossível chegar até o final. Deixo uma lembrança também à equipe do Centro de Documentação e Informação (CEDI) da Câmara dos Deputados, pelo auxílio importante sobre como achar informações no interior dos sites da Câmara e do Senado.

Demais amigos e colaboradores merecem ser citados pois efetivamente me ajudaram, seja com palavras de incentivo e interesse, seja dedicando parte de seu tempo em valiosas dicas e informações de pesquisa e na procura de livros de difícil acesso, inclusive fora do país, sem os quais este trabalho não teria o mesmo resultado. Meu obrigado a Ana Luíza Backes, Andrea Freitas, Carla Carvalho, Cesar Silva, Humberto Dantas e demais colegas da Escola de Formação Política, Iris de Oliveira, Ivo Luiz Heinz, Jacqueline Teixeira Kawauche, Kelicler Toledo, Lúcia Rodrigues, Roberto de Sousa Causo e Rossana Arouck Damasceno.

Uma realizão coletiva, como se vê, requisito indispensável a todo trabalho intelectual que se digne como honesto em sua realização e propósito, mas que em última análise tem apenas a mim mesmo como o responsável pelos erros e acertos apresentados. 


\section{Resumo}

Este trabalho discute o federalismo do ponto de vista de suas relações com o regime político democrático. Se o argumento de Alfred Stepan (1999) é de que o federalismo constrange as decisões do centro nacional e por isso seria anti-democrático, contrapõem-se uma visão consociativa, no qual o federalismo é visto como importante para integrar minorias dentro de sociedades eminentemente heterogêneas. A referência aqui é o trabalho de Arend Lijphart (2003).

A democracia federativa brasileira é o campo de análise empírico, por meio de uma de suas instituições federativas, o Senado Federal. Examinamos os efeitos da desproporcionalidade desta casa com os da Câmara dos Deputados, a partir das possibilidades eventuais de vetos às propostas de emendas à Constituição. E a partir daí analisamos o governo de Fernando Henrique Cardoso (1995-2002), por causa de seu caráter reformista, através de emendas constitucionais, a maior parte delas com impacto federativo. E se dentre estas emendas, as de caráter fiscal são as mais recorrentes, pesquisamos o papel do Senado no processo de ajuste fiscal deste governo, primeiro com relação à renegociação das dívidas estaduais e em segundo nas votações nominais do Fundo Social de Emergência (FSE) e suas renovações. Com isso procuramos verificar se, como e em que situações o Senado atuaria em defesa dos interesses dos estados (e regiões) que representa ou cooperaria com os intereses do governo, por meio dos partidos políticos.

\section{Palavras-chave:}

Federalismo; democracia; senado federal; Fernando Henrique Cardoso; ajuste fiscal. 


\begin{abstract}
This work discusses federalism from the standpoint of its relationship with the democratic political regime. If the viewpoint of Alfred Stepan (1999) is that federalism constrains decisionmaking at the national center, thus becoming anti-democratic, a consociative view is opposed: federalism would be important for the integration of minorities within eminently heterogeneous societies. In this work, the reference will be the work of Arend Lijphart (2003).

The Brazilian federative democracy is the empirical field of analysis, through its federative institutions, the Federal Senate. We examine the effects of the disproportionallity of that body in relation to the Chamber of Deputies, manifest in the eventual possibilities of vetoes to proposed amendments to the Constitution, and we analyze the administration of Fernando Henrique Cardoso (1995-2002), because of its reformist character, through constitutional amendments, most of them with federative impact. Since among those amendments, the fiscal-related ones are the most recurrent, we have researched the role of the Senate in the process of fiscal adjustment made by that administration, firstly in relation to the renegotiation of state-debts, and secondly in relation to nominal voting concerning Fundo Social de Emergência (FSE, or Emergency Social Fund) and its extensions. With that we have tried to verify whether, how and in which situations the Senate would be acting on behalf of the interest of the States (and regions) that the Senate represents, or whether it would cooperate with the interests of the administration, through party politics.
\end{abstract}

\title{
Key Words:
}

Federalism; democracy; federal senate; Fernando Henrique Cardoso; fiscal adjustment. 


\section{Sumário}

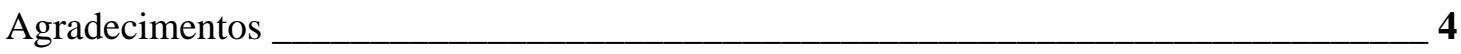

Resumo ___ 6

Abstract __ 7

Índice ___ 9

Índice das tabelas _______ 12

Introdução ___ 15

Capítulo $1+19$

Capítulo $2 \ldots 42$

Capítulo $3 \ldots 63$

Capítulo 4

Conclusão ___ 154

Referências Bibliográficas ___ 159

Anexos ___ 166 


\section{Índice}

Introdução 15

Capítulo 1: Efeitos institucionais entre federalismo e democracia 19

Definição e modelos de origem 21

Regimes políticos 24

Democracia com federalismo 27

Dois modelos de representação democrática 34

Conclusões 40

Capítulo 2: Representação federativa e o caso brasileiro 42

Características do bicameralismo 43

Representação federativa no caso brasileiro 46

Simetria e vetos através das emendas constitucionais 54

Conclusões 60

Capítulo 3: O governo reformista de Fernando Henrique Cardoso 63

Antecedentes, o novo contexto e o Plano Real 64

Emendar para governar 72

Reformas federativas por via constitucional 76

Do perfil das emendas de tema federativo 83

Ajuste fiscal e políticas sociais

Conclusões 95

Capítulo 4: A atuação do Senado Federal no processo de ajuste fiscal dos anos 90 97

O contexto descentralizador 99

Ajuste fiscal: dívidas dos estados e fundos fiscais 101

Os estados e seus bancos deficitários 116

Papel do Senado 
Fundo de Estabilização Fiscal 1

Fundo de Estabilização Fiscal 2

130

Desvinculação das Receitas da União

137

Conclusão: ao invés de veto, há cooperação com o governo

147

Conclusões 154

Referências Bibliográficas 159

Anexos 166

1 - Propostas de emendas constitucionais aprovadas no governo de Fernando Henrique Cardoso (1995-2002) 166

Primeiro mandato (1995-1998) 166

Segundo mandato (1999-2002) 170

2 - Textos integrais das emendas constitucionais relativas ao Fundo Social de Emergência e suas renovações 176

Emenda Constitucional de Revisão n.1 - 1994 176

Emenda Constitucional n. 10 - 1996 179

Emenda Constitucional n. 17 - 1997 182

Emenda Constitucional n. $27-2000$ 184

3 - Senado Federal do Brasil: Legislaturas 50 ${ }^{\mathrm{a}}$. e 51 ${ }^{\mathrm{a}}$. (1995-2003) 186

Senadores titulares na 50a . legislatura (1995-1999) por partido 186

Senadores ex-suplentes na $50^{\mathrm{a}}$. legislatura (1995-1999) por partido 188

Senadores titulares na 50 ${ }^{\mathrm{a}}$. legislatura (1995-1999) por região 190

Senadores ex-suplentes na 50ª legislatura (1995-1999) por região 193

Senadores titulares na $51^{\mathrm{a}}$. legislatura (1999-2003) por partido 195

Senadores ex-suplentes na $51^{\mathrm{a}}$. legislatura (1999-2003) por partido 197 
Senadores titulares na 51 ${ }^{\mathrm{a}}$. legislatura (1999-2003) por região

Senadores ex-suplentes na $51^{\text {a }}$. legislatura (1999-2003) por região 202

4 - Votação dos senadores nas emendas constitucionais de tema fiscal por ordem al-

fabética 204

Emenda Constitucional de Revisão n.1 (Fundo Social de Emergência) 204

Emenda Constitucional n.10 (Fundo de Estabilização Fiscal) 207

Emenda Constitucional n.17 (Fundo de Estabilização Fiscal 2) 209

Emenda Constitucional n.27 (Desvinculação das Receitas da União) 213 


\section{Índice das tabelas}

\section{Capítulo 2}

Tabela 2.1 - Representação dos Estados na Câmara dos Deputados 48

Tabela 2.2 - Representação dos Estados no Senado Federal 50

Tabela 2.3 - Desproporcionalidade de representação legislativa federal brasileira por região 53

Tabela 2.4 - Situações possíveis de veto na Câmara dos Deputados para propostas de emendas à Constituição com a representação atual 56

Tabela 2.5 - Situações possíveis de veto na Câmara dos Deputados para propostas de emendas à Constituição com a representação proporcional corrigida 57

Tabela 2.6 - Situações possíveis de veto no Senado Federal para propostas de emendas à Constituição 58

\section{Capítulo 3}

Tabela 3.1 - Emendas constitucionais aprovadas (1992-2006) por área temática 79

Tabela 3.2 - Emendas à Constituição (1992-2006) aprovadas por cada governo segundo sua autoria 80

Tabela 3.3 - Emendas constitucionais aprovadas pela Câmara e Senado segundo a posição política 82

Tabela 3.4 - Emendas constitucionais nos governos FHC de tema federativo por sua área 85

Tabela 3.5 - Emendas constitucionais aprovadas por área temática segundo sua autoria nos governos FHC 86

Tabela 3.6 - Emendas constitucionais federativas aprovadas por área temática nos governos FHC segundo sua autoria 87 


\section{Capítulo 4}

Tabela 4.1 - Votação em primeiro turno do Congresso Nacional da Emenda Constitucional de Revisão no. 1 (relativa ao FSE) - 9/2/1994 104

Tabela 4.2 - Votação em primeiro turno do Congresso Nacional da Emenda Constitucional de Revisão no. 1 (relativa ao FSE), do ponto de vista das regiões do país 106

Tabela 4.3 - Votação em segundo turno do Congresso Nacional da Emenda Constitucional de Revisão no. 1 (relativa ao FSE) - 24/2/1994 107

Tabela 4.4 - Votação em segundo turno do Congresso Nacional da Emenda Constitucional de Revisão no. 1 (relativa ao FSE), do ponto de vista das regiões do país 108

Tabela 4.5 - Votação em primeiro turno dos senadores da Emenda Constitucional de Revisão no. 1 (relativa ao FSE) - 9/2/1994 111

Tabela 4.6 - Votação em segundo turno dos senadores da Emenda Constitucional de Revisão no. 1 (relativa ao FSE) - 24/2/1994 112

Tabela 4.7 - Resultado da votação em primeiro turno dos senadores da Emenda Constitucional de Revisão no. 1 (relativa ao FSE), do ponto de vista das regiões do país 113 Tabela 4.8 - Votação em segundo turno dos senadores da Emenda Constitucional de Revisão no. 1 (relativa ao FSE), do ponto de vista das regiões do país 113

Tabela 4.9 - Votação em primeiro turno do Senado Federal da Emenda Constitucional no. 10 (relativa ao FEF) - 13/2/1996 126

Tabela 4.10 - Votação em primeiro turno do Senado Federal da Emenda Constitucional no. 10 (relativa ao FEF), do ponto de vista das regiões do país 127

Tabela 4.11 - Votação em segundo turno do Senado Federal da Emenda Constitucional no. 10 (relativa ao FEF) - 29/2/1996 128

Tabela 4.12 - Votação em segundo turno do Senado Federal da Emenda Constitucional no. 10 (relativa ao FEF), do ponto de vista das regiões do país 129 
Tabela 4.13 - Votação em primeiro turno do Senado Federal da Emenda Constitucional no. 17 (relativa ao FEF 2) - 5/11/1997 132

Tabela 4.14 - Votação em primeiro turno do Senado Federal da Emenda Constitucional no. 17 (relativa ao FEF 2), do ponto de vista das regiões do país 133

Tabela 4.15 - Votação da Emenda n.o 1 (de Redação), do Senado Federal da Emenda Constitucional no. 17 (relativa ao FEF 2) - 5/11/1997 134

Tabela 4.16 - Votação da Emenda n.o 1 (de Redação), do Senado Federal da Emenda Constitucional no. 17 (relativa ao FEF 2), do ponto de vista das regiões do país 134

Tabela 4.17 - Votação em segundo turno do Senado Federal da Emenda Constitucional no. 17 (relativa ao FEF 2) - 19/11/1997 135

Tabela 4.18 - Votação em segundo turno do Senado Federal da Emenda Constitucional no. 17 (relativa ao FEF 2), do ponto de vista das regiões do país 136

Tabela 4.19 - Votação em primeiro turno do Senado Federal da Emenda Constitucional no. 27 (relativa a DRU) - 23/2/2000 141

Tabela 4.20 - Votação em primeiro turno do Senado Federal da Emenda Constitucional no. 27 (relativa a DRU), do ponto de vista das regiões do país 142

Tabela 4.21 - Votação em segundo turno do Senado Federal da Emenda Constitucional no. 27 (relativa a DRU) - 15/3/2000 143

Tabela 4.22 - Votação em segundo turno do Senado Federal da Emenda Constitucional no. 27 (relativa a DRU), do ponto de vista das regiões do país 144

Tabela 4.23 - Número de votações nominais nas emendas 10, 17 e 27 152 


\section{Introdução}

Vivemos numa época marcada pelo valor maior da democracia como maneira de organizar politicamente a sociedade. O que pode parecer óbvio à primeira vista é, na verdade, resultado de lutas dramáticas em nossa história contemporânea, que nos levou a este bom termo.

Se podemos partir deste acordo básico quanto ao tipo de regime político mais justo, seguro e civilizado, os meios e as regras para organizar internamente as instituições e as leis suscitam mais controvérsia, pois retratam as particularidades e problemas de uma dada sociedade em um dado país.

O caso do Brasil é ilustrativo. O regime é democrático e está estruturado em um sistema político que procura dar conta das contradições e desafios que o país busca superar desde longa data. Como por exemplo, a integração socioeconômica de um território imenso e desigualmente ocupado.

E em parte para traduzir esta e outras características, o país adotou o federalismo a partir de 1891 com a promulgação da primeira Constituição republicana. Aliás, tanto a forma de governo, como o tipo de divisão interna do Estado faziam parte de duas das três principais bandeiras políticas desde a segunda metade do século XIX, ao lado do abolicionismo.

É verdade que alguns questionam a implantação do federalismo como sendo menos uma motivação para integrar os entes numa federação mais equilibrada, do que como uma maneira de fortalecer os estados mais fortes em relação à União e aos outros estados mais fracos, em termos políticos e econômicos. (Carvalho, 1993). O período histórico de então, a República Velha, de fato concentrou o poder em São Paulo e Minas Gerais sendo, talvez, o de desiguldade mais explícita na federação vigente no país.

De qualquer maneira podemos afirmar que desde o início de seu funcionamento o federalismo brasileiro procurou traduzir a profunda desigualdade regional, seja para agravá-lo em algumas épocas por concentrar o poder em poucos estados, seja para minorá-lo em outras, ao procurar equilibrar mais o poder dentro do arranjo instituído, ora com mecanismos de fortalecimento da União ou com métodos de escolha mais democráticos. 
Não é o caso de escrevermos um histórico do federalismo brasileiro através de seu funcionamento nos diferentes períodos da República - aliás, marcada por seguidas rupturas institucionais -, mas chamar a atenção para o fato de que os desafios sob os quais ele nasceu continuam influenciando em boa medida a agenda política do país neste início de século XXI.

Nesta linha este trabalho tem por objetivo entender alguns destes aspectos do federalismo brasileiro, em especial com a democracia, tomando como campo principal de análise as ações e as características do Senado Federal, a casa legislativa que representa os estados no Congresso Nacional.

A inspiração intelectual vem do artigo de Alfred Stepan (1999), que recolocou nos estudos comparados de Ciência Política a relação pouco trabalhada entre o regime político democrático e uma das instituições possíveis de adoção em seu interior, o federalismo. E o contexto desta aproximação ocorre, em grande medida, como um rescaldo da ampla literatura sobre as transições democráticas, que foram vividas por vários países em desenvolvimento a partir de meados dos anos 80 do século passado. Pois o que o autor procura analisar é que consequiências pode trazer o federalismo, partindo-se do princípio de que estas novas democracias estão em processo de reconstrução de suas instituições sob uma nova ordem constitucional.

Isso porque Stepan argumenta que as instituições federativas restringem a capacidade de ação do governo nacional, o que poderia dificultar a agenda de reformas e, mais que isso, expressar um conteúdo anti-democrático, pois atenderia a desejos de minorias regionalmente representadas, seja nos governos locais, seja no Legislativo nacional. Este argumento, que será problematizado ao longo do trabalho em contraposição com uma visão mais consensual da democracia serve como ponto de partida e suporte à pesquisa empírica que procurará verificar em que medida pode eventualmente ocorrer para o caso brasileiro. Nesse sentido o debate subjacente envolve a discussão de vários aspectos relacionados com a democracia e o federalismo, organizados da seguinte maneira nos capítulos.

No primeiro são discutidos os principais pontos entre a democracia e o federalismo, começando pela dificuldade de definição da forma federada de divisão do poder, das motivações para a sua adoção e os reflexos posteriores entre uma sociedade mais homogênea ou heterogênea. A democracia é vista como uma garantia para o funcionamento pleno do federalismo, baseado no binômio do constitucionalismo e das eleições. A partir daí são analisados os modelos majoritário e con- 
sensual de democracia, no interior dos países federativos. Pois esta última discussão problematiza em termos normativos os questionamentos de Stepan, recolocando-os sob um prisma inverso, a de que uma democracia federativa está baseada numa sociedade que valoriza a diversidade na unidade e, por isso, assim justifica um centro nacional contraposto pelo poder dos membros que a compõe.

O segundo capítulo é mais específico, ao tratar inicialmente das características mais importantes do bicameralismo - uma instituição legislativa presente na maior parte das federações - e em especial para o caso brasileiro. Primeiro com relação ao processo legislativo, ao verificar a extensão do poder entre a Câmara dos Deputados e o Senado Federal, e em segundo explorando a controversa questão da desproporcionalidade no Legislativo nacional, ampliando a discussão para o Senado, o que é pouco comum na literatura dedicada a este assunto. O caminho é o da clivagem básica que demarca a desigualdade regional do país, entre as regiões mais pobres, menos povoadas e sobrerepresentadas do Norte, Nordeste e Centro-Oeste de um lado e as regiões mais ricas, mais povoadas e sub-representadas do Sudeste e do Sul, de outro.

Através da análise dos números mínimos para o veto de uma Proposta de Emenda à Constituição (PEC) - por causa da maior substância das questões, inclusive do ponto de vista federativo e da equivalência do poder entre as duas casas - verificamos se, como e em que situações as três regiões sobre-representadas fazem valer seus interesses sobre as regiões sub-representadas. Como será mostrado, a despeito da dupla desproporcionalidade - Câmara mais Senado - os mecanismos consociativos de representação comum às federações podem operar de forma concreta, se eventualmente acionados, no caso brasileiro.

Nesse sentido, a partir do capítulo terceiro entramos na análise empírica do trabalho. Dentre os governos pós-1985, o mais longo foi o do presidente Fernando Henrique Cardoso (1995-2002). Através de seus dois mandatos a economia nacional foi reorganizada, com o fim da inflação de dois dígitos mensais e com um grande programa de reformas do Estado. Para levar à frente o segundo aspecto, o mecanismo utilizado foi o das emendas à Constituição. Assim, analisamos as características deste governo a partir destas mudanças, em especial aquelas com impacto federativo, que foram a maioria. Aprofundamos a questão, subdividindo os tipos de emendas de efeito federativo, constatando que as de caráter fiscal foram as que mais ocorreram. Como se verá, este fato demonstra o perfil e os rumos das reformas, que procurou alterar, entre outras questões, o equilíbrio político entre os estados e a União. 
O quarto capítulo aprofunda esta última sentença, tendo como foco o papel desempenhado pelo Senado Federal no processo duplo de ajuste fiscal, o da renegociação das dívidas dos bancos estaduais e o da criação do Fundo Social de Emergência (FSE) e suas renovações. No caso das dívidas estaduais, isso será mostrado por meio da análise de como aconteceram as negociações entre o governo federal e os estados dentro do Congresso Nacional e no caso dos fundos, através de cada uma das votações nominais das emendas constitucionais que os aprovaram. Esta análise do Senado procurará mostrar fundamentalmente de que forma atuou, ou seja, se é possível constatar se defendeu mais os interesses dos estados ou foi mais cooperativo com os interesses da União, através do apoio dos partidos políticos.

Enfim, mesmo levando-se em conta o poder de veto alocado no Senado a favor das regiões menos desenvolvidas e admitindo-se as consequiências deletérias para a maioria democrática que isso representa, na prática é possível verificarmos se isto pode eventualmente acontecer numa situação concreta? Os resultados nos dará subsídios para interpretarmos o Senado como uma casa de maior ou menor importância federativa, especialmente nos casos analisados que - como se verá alteraram de forma significativa a relação de força entre os estados e a União.

Para além da dicotomia 'centralização-descentralização', tradicional nos estudos do federalismo no Brasil, a linha analítica proposta neste trabalho é enfocar o funcionamento da democracia federativa brasileira do ponto de vista da representação política e da instituição legislativa federativa, o Senado, com a intenção de acrescentar este ângulo ao vasto e complexo debate sobre o sistema político democrático brasileiro. 


\section{Capítulo 1}

\section{Efeitos institucionais entre federalismo e democracia}

O federalismo é uma instituição especifica para a divisão interna do poder político. Existe uma ampla discussão em torno de suas origens, definições, desenvolvimento e características. Mas a relação principal que buscamos refere-se apenas com o regime político democrático, ou mais especificamente da relação entre federalismo e democracia. Pouco abordado tanto dentro das fileiras dos estudiosos do federalismo, como da teoria democrática, mais recentemente ganhou algum relevo com os trabalhos de Alfred Stepan (1999, 2002, 2004a, 2004b). Contudo, se o ressurgimento deste debate é importante por enriquecer e aproximar os dois campos de estudo até então relativamente distantes, faz-se oportuno ir além e problematizar alguns dos principais argumentos defendidos por este autor, que encerra mesmo uma idéia própria do que seja uma federação e uma democracia.

Stepan concebe a reflexão das federações que operam no interior de regimes democráticos a partir de uma premissa geral. A de que, por definição, todas as federações limitam o poder do centro, que representa o demos nacional. Desta maneira, tornaria mais difícil a execução de mudanças políticas por parte do governo nacional, podendo se tornar uma instituição de caráter antidemocrático.

Ao contrário o federalismo também é visto com uma instituição que promove objetivos de convivência comum de grupos políticos, sociais e de recorte nacionalista dentro de um mesmo Estado. Ajudaria a desconcentrar o poder, tanto do ponto de vista do poder político, como das relações

entre os entes e proteger setores minoritários da sociedade. Promoveria a diversidade no interior de uma unidade e expressaria, nesse sentido, uma idéia democrática.

Então por que podemos entender o federalismo como um mecanismo de restrição de vontade de maiorias, protegendo certos grupos ou demandas minoritárias, de uma forma anti-democrática? Subjaz no interior destas duas visões interpretativas de uma mesma instituição política, concepções diferentes do que se entende por democracia, em termos de sua representação eletiva e da distribuição de poder dentro do arranjo instituído. Aqui será útil a análise dos chamados dois modelos de democracia, o majoritário e o consensual, de Arend Lijphart (2003). 
Como veremos, esta reabertura do debate entre o federalismo e a democracia situa-se no contexto das chamadas novas democracias, de meados dos anos 80 do século passado para cá, em que estes países - e em especial os de arranjo federativo - tiveram de institucionalizar o novo regime e recontruir suas instituições e o próprio modelo de Estado sob pressão das idéias neoliberais, tão influentes no período. Assim, Stepan procura interpretar estas novas democracias federativas, do ponto de vista dos possíveis efeitos deste arranjo institucional em regimes políticos em formação. A intenção é situar este debate e suas conseqüências, principalmente do ângulo normativo.

Trataremos de forma breve as dificuldades inerentes à uma definição de federalismo, suas origens e diferentes objetivos de suas soluções. De saída apontamos que é difícil uma definição, por causa das grandes variações institucionais internas em cada um deles e as diferentes maneiras em que ele é aplicado na prática. Em parte esta variação está vinculada às motivações de sua origem, como os três modelos que serão expostos, primeiro daqueles que unem o que estava separado (come together), depois o que separa em partes o centralizado (hold together) e ainda aquele que une de forma impositiva sob o formato federal (put togheter). Pois cada um destes modelos de origem revela em boa parte as diferenças posteriores entre eles.

E para além destas distinções, o regime democrático seria uma garantia ao pleno funcionamento e manutenção de uma federação. Desta maneira, discutimos o federalismo sob vigência de uma democracia e de um regime autoritário, procurando extrair as diferenças entre os regimes políticos e mostrar a importância da democracia.

A partir deste ponto, o debate concentra-se entre os argumentos anti-federativos (e majoritários) de Stepan e aqueles consociativos (e favoráveis aos arranjos federativos), por parte de Lijphart. Se o primeiro autor entende que o federalismo limita o poder do centro em tomar decisões, afetando com isso o interesse de maiorias, o segundo autor a vê no sentido de incluir os vários grupos distintos numa sociedade, procurando aumentar a representação para uma maioria maior, em tese, mais propícia à divisões internas e à valorização da diversidade.

O debate será reconstituído tendo por referência empírica o caso brasileiro, objeto deste trabalho. E é isso que será realizado nos capítulos posteriores - principalmente o três e o quatro -, quando analisaremos o federalismo brasileiro atual durante os governos reformistas de Fernando Henrique Cardoso (1995-2002) e, mais detidamente, os efeitos das negociações políticas em torno 
de aspectos do ajuste fiscal, como a renegociação das dívidas dos estados e o Fundo Social de Emergência (FSE) e suas renovações.

\section{Definição e modelos de origem}

Em termos históricos é possível identificar o surgimento do que hoje entendemos por federalismo no fim do século XVIII, com a promulgação da Constituição dos Estados Unidos. Todos os sistemas federativos posteriores, de alguma forma, teriam como referência o modelo criado pelos americanos. O fato é que nos séculos XIX e XX o número de países que adotaram esta forma de divisão interna de poder aumentou muito. Talvez devido ao êxito dos Estados Unidos e também ao fim do período de domínio colonial por parte dos países europeus, o que teria ensejado a criação de sistemas federativos nos países recém-libertos em praticamente todas as partes do globo, da América Latina para a África e da Ásia para a Oceania. Segundo William Riker (1993), as novas federações surgiram principalmente nas ex-colônias do então Império Britânico.

O federalismo é uma das instituições políticas mais difíceis de uma definição precisa. Mesmo assim podemos entender o federalismo como uma forma de organização do Estado nacional caracterizada pela dupla autonomia territorial do poder político, na qual se distinguem duas esferas autônomas de poder: uma central, que constitui o governo federal, e outra descentralizada, que constitui os governos membros, sendo que ambas têm poderes únicos e concorrentes para governar sobre o mesmo território e as mesmas pessoas. ${ }^{1}$ Para que este arranjo de divisão de poder seja seguro em sua manutenção e dinâmico em seus princípios, ele deve ter garantias constitucionais, pelo primeiro aspecto e ter vigência política em um regime democrático, por outro.

A tentativa de construção de uma tipologia sólida e amplamente aceita ainda está em curso entre seus estudiosos e há um caminho longo a ser percorrido, porque o federalismo não é em si mesmo um regime político - tal qual uma democracia ou um autoritarismo -, mas uma instituição que opera no interior de um regime. Daí, em tese, se prestaria a uma variedade de experimentos maiores, de acordo com as especificidades de cada país que o aplica.

O significado etimológico do termo 'federal' é derivado do latim foedus, que significa pacto. Essencialmente, é um arranjo federal, uma parceria, estabelecida e regulada por um pacto, em que

\footnotetext{
${ }^{1}$ Algumas poucas federações possuem tripla autonomia territorial, isto é, os municípios também são entes federativos, mesmo que com menos funções, poderes e representação que os estados. Refiro-me ao Brasil, a partir da Constituição de 1988, à Índia, com boa parte de governos locais dentro dos estados com status federativo e à Bélgica, depois da reforma constitucional de 1992.
} 
as conexões internas traduzem um tipo especial de poder entre os parceiros, baseada no reconhecimento mútuo da integridade de cada um e no esforço continuado de favorecer uma unidade especial entre eles. Pois embora este sentido etimológico também possa ser reivindicado para as alianças e confederações, ele é mais apropriado para o federalismo contemporâneo, pois nele as unidades que pactuam, embora mantenham sua identidade, se reúnem em torno de um novo centro de poder comum a todos. E que retém uma única soberania sobre todo o território.

O exemplo histórico dos Estados Unidos facilita a compreensão. Quando as 13 colônias originais se tornaram independentes em 1776 inicialmente haviam se estabelecido como Estados livres, regidos por leis próprias. Para defenderem interesses comuns, resolveram em 1781, formar uma Confederação, mantendo cada um dos 13 estados uma plena independência política entre si e associando-se apenas em algumas questões de comum acordo entre eles.

A partir dos trabalhos da Convenção da Filadélfia em 1787 ganhou corpo a idéia de os Estados livres se tornarem membros de um único país que os reunisse. Pois assim teriam uma defesa militar mais segura e integrada e a possibilidade de expandir o poder político-territorial. Nascia o que Riker (1964) chama de 'federalismo centralizado', ou seja, com instituições que atuam sobre todos os membros, com prevalência em questões que sejam comuns. Ainda segundo este autor, o que existia antes era um 'federalismo periférico', na verdade um outro nome para o que se conhece como aliança ou confederação. A partir da criação desde federalismo centralizado, ele seria um paradigma para todas as formações federativas posteriores. Podemos afirmar, contudo, que não sempre pelas mesmas razões.

Mas não é o que defende Riker. Para ele todos os sistemas federais se originaram por uma razão: uma barganha entre as partes interessadas, baseadas em duas condições: 1) aumento do controle sobre o território, para uma possível expansão militar ou diplomática e 2) a proteção que cada unidade que forma o pacto deseja para se defender de uma agressão militar ou participar dela conjuntamente com as demais. Estas duas precondições podem ser resumidas, na condição de expansão do território e de proteção militar. (Riker, 1964:13). ${ }^{2}$

Entretanto, com a generalização do seu argumento para todos os casos de formação de sistemas federativos, o problema é que nem sempre a, digamos, receita, dá certo. As motivações e as

\footnotetext{
${ }^{2}$ Numa obra posterior, em 1975, o autor passa a considerar também a motivação baseada na 'ameaça interna', para justificar a criação do que ele nomeia de federalismo centralizado.
} 
realidades de outros países podem e geralmente são diferentes. E ainda que em algum nível (ou em alguns casos) a barganha militar tenha sido importante para a criação de um federalismo, mesmo neste caso ela é diferente do modelo original, pois a realidade específica é outra.

Marta Arretche (2001) aponta que o problema da generalização do argumento da barganha com fins militares para outros países, é que toma como base metodológica o princípio de que "a versão moderna do Estado federativo foi uma invenção norte-americana e, portanto, qualquer interpretação da natureza dos Estados federativos deveria ser construída por referência às instituições políticas inventadas pela Convenção da Filadélfia”. (Arretche, 2001:24).

Alfred Stepan (1999) concorda com ela. Pois a barganha de Riker é o que ele chama de coming together, ou seja, a união de partes anteriormente separadas em um único e novo corpo central na forma federativa. Ao modelo de Riker, ele propõe ao menos mais dois, o holding together e o putting together, no qual, se a motivação militar ainda possa ser postulada, ela é apenas mais uma e não necessariamente a principal ou a única para a formação de um estado federativo.

O segundo modo de formação federativa, o holding together procura manter unido um território já existente. Delega poderes e autonomia às suas partes constituintes, desconcentra o poder do centro, para permitir que todas as partes mantenham sua existência e identidade própria e, ao mesmo tempo, integrem um único Estado que os reúne. Esta é uma interpretação básica para o caso dos países com diferenças multinacionais. Um Estado com duas ou mais nações em seu interior. A adoção do federalismo neste caso cumpre um papel de manutenção da existência de um país, bem como confere proteção às minorias que o compõe. Em casos como este, "as unidades subnacionais não eram estados independentes cuja soberania prévia lhes conferia um poder de barganha, que pudesse ser comparável a trajetória dos estados norte-americanos, o que implicou que os governos regionais tivessem menos soberania e menos poder de barganha em relação ao governo central." (Idem, 2001:26).

Pode existir também uma variação, no sentido de um Estado criado para ser habitado por diferentes etnias dentro de um só território. Além de compartilhar com o aspecto nacionalista do modelo holding together, para Stepan esta variação estaria mais próxima de um outro modo de criar uma federação, o que ele chama de putting together. O caso aqui é o de uma nação mais poderosa do que outras, que as incorpora de forma impositiva em um novo Estado, num formato federativo. 
O autor dá o exemplo da União Soviética, quando a Rússia incorporou ao seu domínio vários países eslavos e asiáticos, que faziam fronteiras com o seu território.

Temos, então, três maneiras em que os estados federais podem ser formados, mas mesmo que a ameaça militar possa estar ausente como motivo principal, ela pode, em tese, servir de necessidade também nos dois outros casos apresentados por Stepan. Países e nações intimidados ou ameaçados de sanções ou invasões, podem decidir por uma união federativa para sua defesa comum, mesmo que eles tenham suas próprias diferenças étnicas, linguísticas ou religiosas. Adiante veremos como estas concepções diferentes de formação do arranjo federativo estão ligadas com as críticas que fez Stepan às federações como mais ou menos limitadores do poder do centro nacional.

\section{Regimes políticos}

Como vimos, em todos os atributos definidores do federalismo e na operacionalização de cada um de seus modelos de formação estão embutidos os princípios democráticos. Pois na apresentação de uma definição de federalismo ressaltei que é necessário que o pacto que lhe deu forma, tenha como um dos seus pressupostos a representação política eletiva, o que por extensão, nos conduz à democracia.

Um dos principais defensores da importância da democracia para o funcionamento dos mecanismos federativos e sua garantia, é Stepan (1999). É possível democracias sem federalismo. Mas não o contrário.

O autor chega a conceituar o federalismo em consonância com a democracia. Como se o sistema federativo dependesse deste tipo de regime político para existir ou ser minimamente operativo. Edward Gibson (2004) situa esta vinculação no que ele chama de 'escola democrática' de interpretação do federalismo. ${ }^{3}$ Desta forma, "o federalismo é visto como intimamente conectado com a prática democrática, a partir de uma perspectiva que vê o governo local como mais 'responsivo'aos cidadãos individuais do que os governos nacionais, ou como uma proteção contra a usurpação de um governo central." (Gibson: 2004:11).

\footnotetext{
${ }^{3}$ A outra escola de interpretação do federalismo, de acordo com este autor, é a da 'eficiência'. Vem da influência de teorias econômicas e fiscais do federalismo, especialmente a partir do trabalho de Charles Tiebout (1956), que defendeu a relevância da competição entre os níveis de governo para a provisão eficaz e a distribuição de bens e serviços.
} 
Stepan procura analisar o que poderíamos chamar de 'democracia federativa', com uma interpretação da perspectiva do regime político e não da divisão interna de poder. Em outras palavras, como funcionam os regimes democráticos que tem entre uma de suas instituições operadoras do sistema político, o federalismo. Talvez seja possível dizer que ao adotar esta linha ele não queira polemizar quanto à possibilidade de existência do federalismo fora do regime democrático, pois ele está voltado às características das democracias federativas.

Desta forma, para ele "os sistemas políticos democráticos só devem ser considerados como federativos se atenderem a dois critérios. Primeiro, o Estado deve conter subunidades políticas territoriais, cujo eleitorado seja constituído pelos cidadãos dessas unidades; além disso a Constituição deve garantir a essas unidades soberania na elaboração de leis e de políticas. Segundo, deve haver uma unidade política de âmbito nacional, que contenha o poder legislativo eleito por toda a população do Estado, e à qual caiba, por garantia constitucional, a competência soberana para legislar e formular políticas em determinadas matérias.” (Stepan, 1999:202).

Nota-se que esta definição não é essencialmente diferente daquela proposta no início deste capítulo. O que muda é o enfoque. Pois se a primeira parte de uma perspectiva do federalismo com democracia, a de Stepan enfatiza a democracia com federalismo.

Neste particular cabe uma rápida observação sobre as nuances democráticas, digamos assim, da definição de federalismo de Stepan. Chama a atenção, quando ele diz que o Legislativo nacional deve ser eleito pelas populações das unidades federativas, mas tal afirmação sugere que o sistema de governo seja parlamentarista, ao não sublinhar a fonte do poder Executivo. Embora Stepan esteja se referindo às democracias com federações, cabe um acréscimo de que, caso o sistema de governo seja presidencialista, o eleitorado de cada unidade federativa se converte em um só para eleger um governante para todo o Estado.

Talvez seja possível atribuir a Stepan o mérito de incluir o federalismo dentro da teoria democrática, pois é espantosa a pouquíssima importância ou mesmo ausência de qualquer teorização a esse respeito em obras de autores influentes como Riker (1964) e Ivo Duchacek (1970), entre outros. $^{4}$ Isso é estranho, se consideramos que a própria construção da federação americana, levou em conta a questão da representação eletiva, a diferenciando de forma engenhosa, com uma fonte popu-

\footnotetext{
${ }^{4}$ No índice remissivo da obra principal de Riker (1964), a palavra 'democracia' não aparece. Já na obra de Duchacek (1970) ela surge apenas uma vez, discutida em duas páginas, numa obra de 370.
} 
lar e outra territorial. Além do complemento dos checks and balances, controle entre os poderes, para que nenhum possa ir além de suas atribuições e usurpar os outros ou mesmo as unidades constituintes de uma federação. Ou seja, na própria idéia de federalismo está embutida uma fonte de soberania popular.

Em uma democracia, teoricamente, todos os mecanismos responsáveis pelo funcionamento de uma federação podem ser realizados e de forma segura. Isso porque a fonte de legitimidade do pacto federal é uma Constituição promulgada por representantes eleitos pelos cidadãos. Além disso, os governantes dos poderes Executivo e Legislativo em nível nacional (no caso do sistema de governo ser presidencialista) ou apenas do Legislativo em nível nacional (no caso do sistema de governo ser parlamentarista) e em nível estadual - e em alguns países também em nível municipal são periodicamente escolhidos por meio de eleições, o que lhes garante legitimidade para executar os instrumentos federativos, garantidos no texto constitucional. A garantia de soberania interna de cada membro da federação é dupla, pois está escrita na Constituição e tem respaldo político popular. 5

Já em um regime político autoritário há uma centralização discricionária do poder político, gerando uma situação de desigualdade entre os entes federados. Os princípios federativos até podem estar presentes na Constituição, mas na ausência de eleições em nível nacional e/ou estadual, a legitimidade dos governantes é limitada e, portanto, sujeita a critérios políticos autoritários. Mesmo o texto constitucional pode ser alterado em função dos interesses políticos dos detentores de poder, colocando em risco a própria permanência da federação.

Em termos históricos regimes políticos não-democráticos funcionaram sob um formato legal federativo. Os exemplos são vários, como os casos do Brasil durante a ditadura militar (1964-1985), o México, durante as décadas em que esteve sob a hegemonia do Partido Revolucionário Institucional (PRI) - de 1929 a 2000 -, e até mesmo um regime totalitário como a União Soviética (19171991), talvez o maior exemplo da compreensão de um federalismo formal, muito longe de existir concretamente.

Desta forma, ainda que uma federação só possa ter segurança em uma democracia, ela pode operar no interior de um regime não-democrático, levando-se em conta todas as suas restrições de

\footnotetext{
5 Para Preston King (1982) o que garante a especificidade do pacto federativo é o que ele chama de 'entrelaçamento' entre o governo nacional e os governos membros e a segurança de cada um deles baseada no constitucionalismo.
} 
ordem representativa e sua insegurança em termos constitucionais. Até é possível em termos conceituais que definamos uma federação segundo o seu funcionamento em uma democracia. Mas em termos analíticos esta opção corre o risco de pecar por outro formalismo, isto é, não do arranjo federativo, mas do tipo de regime político, não trazendo muita vantagem na interpretação de um caso concreto. Ou seja, podemos realizar uma análise de uma federação vivendo sob uma ditadura, procurando entender até que ponto os seus mecanismos e características continuam operativos, sem afrouxarmos a relação conceitual que deve existir entre uma federação e uma democracia. ${ }^{6}$

Como se vê, o tipo de regime político é fundamental para entendermos como uma federação funciona. Até que ponto suas instituições, garantias constitucionais e agentes políticos têm, de fato, meios de tornar concretos os seus pressupostos. Pois agora é o momento de verificarmos de que maneira os diferentes arranjos federativos influem nas características e no funcionamento de um regime democrático.

\section{Democracia com federalismo}

De acordo com Arretche "a partir de meados dos anos 80 [do século passado] produziu-se um deslocamento na agenda de pesquisas norte-americanas sobre o federalismo: de um debate centrado nas especificidades dos estados federativos vis-a-vis os estados unitários e confederações, para um debate centrado no impacto do federalismo sobre a autoridade dos governos centrais, particularmente sua capacidade de mudar o status quo, produzir inovações e implementar reformas políticas." (Ibidem, 2001:27).

Esta mudança de enfoque ocorreu, em parte, por causa da crise dos Estados de bem-estar social, por um lado, estimulados por uma agenda de reformas neoliberais. E de outro, à necessidade de reformar e reconstruir as instituições políticas. No primeiro caso, para os países economicamente desenvolvidos; no segundo caso, para vários dos países recém-democratizados. Estes com o desafio duplo de também levarem em conta a diminuição do tamanho do Estado, segundo a mesma receita neoliberal, muito influente no período. ${ }^{7}$

\footnotetext{
${ }^{6}$ Em um de seus últimos escritos sobre federalismo, Riker (1993) passou a considerar a relação desta instituição com o tipo de regime político, ressaltando a importância da democracia.

${ }^{7}$ Stepan (1999) justifica seu interesse neste tema em resposta ao argumento de Riker (1975), de que o federalismo seria uma instituição de pouca importância dentro de uma democracia, já que o interesse dos cidadãos americanos estaria voltado a questões nacionais e o sistema partidário teria prevalência no jogo político.
} 
Em consonância com este 'deslocamento na agenda das pesquisas', Stepan aproveita para recolocar o federalismo no seio de uma teoria da democracia e, por extensão, avaliar seus eventuais efeitos no processo de produção e execução de políticas por parte do governo nacional.

Nesse sentido, o argumento central de Stepan é que as federações democráticas tendem a restringir as possibilidades de alteração do status quo, porque a autonomia dos governos locais funciona no sentido de dispersar o exercício da prática política, aumentando o poder de veto de grupos minoritários. Em suma, as federações seriam limitadoras do poder do centro, que representa o demos nacional em contrapartida com os demos de cada unidade federal - chamados de demoi.

Neste ponto ficam mais claras as motivações do autor em reexaminar o argumento kikeriano da barganha para o modelo americano que seria 'exportável' para as outras federações criadas posteriormente. Ao destrinchar e subdividir o modelo de Riker - renomeado de coming together (unir o que estava separado) -, há a intenção de mostrar que nem todas as federações seguiram o método americano, tendo como efeito, diferentes razões e formas de construir uma federação, que seria mais ou menos restritiva ao poder central.

Seria possível imaginar um continuum entre uma federação com alta restrição do demos para uma de baixa restrição, que tornaria possível "abrir a categoria analítica histórica do federalismo a uma série de distinções empíricas e conceituais impossíveis de se fazer se apenas agrupamos todos os sistemas federativos em uma categoria única de 'federalismo centralizado'." (Ibidem, 1999:211). O que o autor pretende é desmembrar um conceito já definido como distintivo, o federalismo proposto por Riker, colocando os Estados Unidos não mais como uma referência, mas como um dos extremos deste novo continuum, por causa das características institucionais de formação centralizada deste país.

As democracias federativas restringem o poder central por quatro razões. Primeiro, porque restringem o poder do centro, devido ao poder duplicado de ao menos duas esferas de governo, impedindo a execução de uma agenda inteiramente aberta, além de inibir o poder dos próprios cidadãos. Segundo, porque o demos tem limitações verticais, isto é, de ao menos duas esferas diferentes de governo, e limitações horizontais, por causa do bicameralismo. Terceiro, as constituições podem vincular as próximas gerações aos compromissos dos fundadores, pois é preciso uma supermaioria para modificá-las. E a quarta razão é que, devido à complexidade e detalhismo das constituições, é 
preciso de tribunais que interpretem e se reportem às suas controvérsias, exercendo, na prática, uma função legislativa.

A partir destas quatro razões básicas é possível encontrar muitas variações entre as democracias federativas no grau de restrição que impõem. Desta forma, muitas federações são forjadas com o intuito de ampliar o poder do demos (do centro), dentro dos limites do arranjo federativo. Por isso é que Stepan aponta uma 'deficiência analítica' na concepção de Riker, devido à sua dicotomia entre um federalismo periférico e outro centralizado - que seria o verdadeiro federalismo. Contudo, se existe uma deficiência de análise, creio que ela não está nesta dicotomia - que pode ser questionada apenas em termos nominais, se tanto -, mas sim no paradigma, ao imaginar que o tal 'federalismo centralizado' ao feitio americano, servisse de inspiração e cópia para as federações criadas depois. O que é interessante na análise de Stepan é a possibilidade de destrinchamento do federalismo centralizado, a partir de uma gradação que saia de uma comparação com outros sistemas de divisão interna de poder e siga para uma outra que enfatiza o quanto uma federação pode restringir ou ampliar o poder do demos.

Stepan procura tornar mais claro a construção do conceito de restrição ou ampliação do demos ao ressaltar o que já é conhecido, ou seja, a variação institucional entre sistemas democráticos federativos, que tem como efeito uma grande quantidade de práticas e regras decisórias contidas nas constituições. Estas características de poder espalhado e difuso, contrariaria o chamado princípio democrático de igualdade do voto - 'uma pessoa, um voto'.

Também há os chamados padrões paraconstitucionais - voltados à operação prática do jogo político -, que podem diminuir ou exaberbar os limites impostos à capacidade de formulação de políticas de uma maioria nacional. "Enquanto cada um desses fatores tem um impacto na capacidade de legislar do demos, o mais importante é como interagem de modo a impedir sistematicamente a capacidade de uma maioria potencial para alterar ou favorecer o status quo ou facilitar - dentro dos limites das áreas constitucionalmente garantidas dos direitos das unidades territoriais -, a capacidade de uma maioria criar decisões de alcance nacional que considere necessárias para a qualidade da democracia e a eficácia do processo de elaboração de políticas.” (Ibidem, 1999:218). 
Para aprofundar o seu argumento, além das razões acima expostas, o autor apresenta e discute quatro variáveis institucionais. As três primeiras contidas nas constituições e a quarta, exógena, o sistema partidário. ${ }^{8}$

"Variável 1: O grau de super-representação da câmara territorial [câmara alta].

Proposição: Quanto maior é a super-representação dos estados menos populosos (e, conseqüentemente, a sub-representação dos estados mais populosos), maior é o potencial restritivo do senado.

"Variável 2: A 'abrangência das políticas’ formuladas pela câmara territorial.

Proposição: Quanto maior é a 'abrangência de políticas' formuladas pela câmara que representa o princípio territorial, maior é o seu potencial para limitar a competência legislativa da câmara que representa o princípio da população.

"Variável 3: O grau em que a Constituição confere poder de elaborar políticas às unidades da federação.

Proposição: Quanto maior é a extensão da competência para elaborar políticas que a Constituição retira da alçada legislativa do governo central, mais restringido fica o demos.

"Variável 4: O grau de nacionalização do sistema partidário em suas orientações e sistemas de incentivos.

Proposição: Quanto mais disciplinados são os partidos políticos cujos sistemas de incentivos, principalmente no que diz respeito à indicação de candidatos, privilegiam os interesses do conjunto da sociedade em relação aos interesses locais e provinciais, mais os partidos nacionais têm condições de atenuar as características inerentemente limitadoras do federalismo." (Ibidem, 1999:218-219).

As duas primeiras variáveis estão ligadas ao bicameralismo, uma instituição legislativa comum às federações. A primeira variável sobre a representação política e a segunda sobre a extensão do poder da câmara alta. Já a terceira e a quarta variável relacionam-se mais propriamente com um caráter institucional mais centralizado ou descentralizado, no sentido da amplitude de poderes para os legislativos das unidades federais e quanto o sistema partidário tem uma lógica e um funcionamento mais nacional ou regional.

\footnotetext{
${ }^{8} \mathrm{Na}$ verdade, esta quarta variável é, ao invés, uma consequiência do sistema institucional.
} 
Na primeira variável a questão é a da característica da representação da câmara alta. Ela tem como princípio representar os territórios que compõe uma federação - ou mesmo um estado unitário em alguns casos. Desta forma, se contrapõe com o princípio da câmara baixa, que representa a população de cada unidade territorial que compõe a federação. Enquanto o número de eleitos para a câmara baixa segue um princípio proporcional à população de cada unidade, na câmara alta, ela tem um número igual de representantes para todas as unidades federativas ou regionais. Como a população está distribuída de forma desigual no interior de um país, há unidades mais populosas do que outras. A consequiência destes dois fatos, nos leva a uma desproporção de representação, com as unidades mais populosas sub-representadas e as menos populosas sobre-representadas.

Esta desproporção seria anti-democrática, pois conferiria 'pesos' diferentes aos cidadãos das unidades, com vantagem para aqueles residentes nas unidades menos populosas. Os interesses das minorias teriam o potencial de restringir os das unidades mais populosas. Em federações, este princípio tem como origem os Estados Unidos, que procurou proteger os interesses dos estados menores em comparação com o maior poderio político dos estados mais populosos. Esta igualdade de representação estaria no cerne do pacto que consagrou a federação, ao conceber um mesmo status a todos os estados - que, aliás, eram politicamente independentes antes de aderirem à união, no modelo descrito acima como coming together.

Embora Stepan tenha consciência das motivações que justificaram a sobre-representação nas câmaras altas, ele a questiona, especialmente no caso dela possuir poderes legislativos equivalentes e métodos de seleção diferentes à da câmara baixa. Nos termos de Lijphart (2003), o bicameralismo forte (simétrico e incongruente) é uma característica comum aos sistemas federativos. Enquanto nos sistemas unitários, o bicameralismo - quando ocorre -, é fraco (assimétrico e com congruência de representação), pois o poder maior está na câmara baixa.

Um problema adicional para esta restrição ao demos provocada pela câmara alta nas federações é que, além dela, também as câmaras baixas apresentam índices de desproporcionalidade. Desta forma, a restrição aos interesses da maioria estaria presente nas duas câmaras legislativas federais. ${ }^{9}$

\footnotetext{
${ }^{9}$ As várias implicações desta questão serão discutidas no próximo capítulo, principalmente para o caso brasileiro.
} 
A Variável 2, já implicitamente apresentada nas linhas acima, explora a questão do poder equivalente da câmara alta em relação à câmara baixa. Com poderes simétricos, a câmara alta limitaria 'a competência legislativa da câmara que representa o princípio da população'. Esta característica é comum nos sistemas federativos, embora por razões diferentes para cada país. E nas chamadas federações multinacionais - com divisões étnicas, religiosas ou linguísticas -, é onde mais têm sido aplicado, pois seria um componente importante para incluir e proteger os grupos minoritários no sistema político do país.

Neste caso o argumento de restrição ao demos teria de ser relativizado, pois não se teria em questão uma federação mononacional, mas multinacional. Para Stepan, neste caso, esta configuração mais consociativa seria justificável. Contudo, neste caso, como ficaria o princípio majoritário da igualdade do voto? Retomaremos esta questão daqui a pouco.

Na Variável 3, o poder de restrição ao demos está localizado no grau de amplitude legislativa conferida aos legislativos dos membros da federação, especialmente em áreas não cobertas pelo governo federal. Esta peculiaridade tiraria poderes do centro e fortaleceria os interesses regionais, quer dizer, de minorias territorialmente localizadas. Também pode ser o caso - dependendo do país -, das unidades regionais terem poder de veto em mudanças na Constituição - como no caso dos Estados Unidos. Neste caso, o caráter restritivo ao demos é mais acentuado.

Se as três primeiras variáveis são constitucionais, a Variável 4 é aquela relativa a uma instituição política periférica, que pode ou não depender do federalismo, o sistema partidário. Riker (1964) argumenta que a operação concreta do sistema partidário prevalece às instituições federativas, tornando-as mais fracas, pois os interesses e lealdades dos agentes políticos é mais nacional (alocadas nos partidos) do que regional.

Desta maneira, esta característica afetaria o caráter nacionalmente mais centralizado ou regionalmente descentralizado dos grupos políticos que atuam numa configuração federativa. Partidos que chegam ao poder nacional com maioria nas casas legislativas ou liderando uma coalizão, em ambos os casos, com disciplina nas votações, além de uma ideologia relativamente homogênea têm uma força de centralização, ainda mais se também ocupam postos executivos e entre os legislativos de ao menos uma parte das unidades regionais. Mas o federalismo, em si mesmo, contrapõe mecanismos de poder próprios às suas unidades regionais, estabelecendo uma espécie de equilíbrio com os interesses nacionais. É preciso levar em conta também que em países com sistemas multipartidá- 
rios e fortes elites regionais, o federalismo mantém-se e tende a ser partidariamente descentralizado. E se falarmos de uma federação multinacional, ainda haverá os partidos regionais, além dos partidos nacionais também terem de levar em consideração os interesses das regiões que compõe o país.

Se de um lado há mecanismos centralizadores na própria idéia de partidos políticos - partes com propostas para o todo -, por outro há os mecanismos descentralizadores na idéia de federalismo - diversidade na unidade -, o que tensiona o sistema político em direções ora mais voltado ao demos nacional, ora mais aos demoi de cada região.

Uma observação adicional a estas variáveis propostas é que elas tomam as divisões políticas do ponto de vista espacial, territorial. Os interesses politicos dos grupos relevantes que disputam o poder dentro de um país estaria localizado, principalmente no interior de cada subunidade. Talvez apenas os partidos políticos seriam uma instituição que contrabalançaria esta tendência, por cruzar os interesses das regiões com os interesses da nação em seu conjunto. Mas mesmo neste caso, a condição analítica proposta por Stepan é de fundo territorial.

Talvez esta linha de interpretação seja mais promissora nos casos das chamadas federações multinacionais - holding together - nos quais os interesses de grupos minoritários sejam mais sensíveis de serem atendidos politicamente. Mas isto apenas no caso destas minorias estarem localizadas espacialmente, o que não é sempre o caso. Podemos aceitar o argumento de que um Estado construído no formato federativo compartilhe de valores que ressalte esta maneira de dividir internamente o poder, ou seja, principalmente em bases territoriais. Para seguirmos King (1982), abrigariam sociedades que valorizam a diversidade dentro de uma unidade comum que as reúne. ${ }^{10}$ Mas mesmo dentro desta concepção temos de levar em conta que as demandas dentro de qualquer corpo político, seja ele federativo ou não, apresentam interesses e conflitos de ordem não espacial, mas de fundo ideológico, econômico e social, dentre os mais importantes. E que eles estão imiscuídos entre si, numa dada configuração institucional, no caso do federalismo, com demandas tão sensíveis ou mais do que os de recorte territorial, que é a dimensão tratada em especial por Stepan e outros teóricos do federalismo.

Feita esta ressalva, creio que a opção metodológica de se priorizar a fonte de poder político localizada no território é válida dentro de uma análise institucional das características de uma de-

\footnotetext{
${ }^{10}$ Este autor diferencia de forma sugestiva o federalismo de uma federação. O primeiro estaria relacionado com uma ideologia e seus valores. E a segunda com sua maneira de funcionar e seus arranjos institucionais.
} 
mocracia federativa. Pois o poder político está dividido em termos territoriais e o legislativo - especialmente a câmara baixa nacional -, tem sua base de representação nas unidades que compõe a federação. $^{11}$

Uma segunda observação é que o modelo de democracia que Stepan defende é o majoritário, da regra da maioria. Nesse sentido ele é um anti-federalista, pois questiona os pressupostos da forma federada de divisão do poder político que é, em si, diferente da regra majoritária.

Maria Hermínia Tavares de Almeida (2001) faz uma crítica aos argumentos anti-federativos de Stepan. Para ela, "nem todos os critérios utilizados pelo autor para classificar as federações segundo as restrições que impõem à igualdade política são claros. Enquanto os dois primeiros dizem respeito diretamente à violação do princípio de 'a cada cidadão um voto', definidor da democracia, os dois últimos parecem sustentar-se em duas premissas mais discutíveis do ponto de vista da normatividade democrática. A primeira é que, em qualquer circunstância e para qualquer assunto, o demos nacional tem precedência sobre os demoi das unidades subnacionais. A segunda é que todas as decisões, qualquer que seja o seu escopo, afetam o conjunto dos cidadãos da nação, razão pela qual, sempre que forem tomadas por um subconjunto territorialmente delimitado dos eleitores, podem ser interpretados como decisões de minoria que limitam o poder da maioria. As duas premissas implicam negar a existência de problemas, interesses e aspirações territorialmente circunscritos que podem ser tratados no âmbito em que se manifestam. Finalmente - e esta é a objeção mais séria -, ao avaliar a relação entre federalismo e democracia, Stepan toma partido por um modelo de democracia majoritária, como se fosse a única possibilidade aceitável do ponto de vista normativo."12 (Almeida, 2001:18-19).

\section{Dois modelos de representação democrática}

Esta última afirmação nos encaminha para uma discussão sobre estes dois modelos de democracia, o majoritário e o consensual dentro do contexto do federalismo.

A interpretação majoritária da democracia - predominante na teoria democrática -, leva em conta dois princípios básicos e, em tese, irrefutáveis. 1) o voto tem o mesmo valor para cada cidadão e 2) entre aqueles que concorrem a um cargo eletivo, o que obtiver a maior soma de votos é de-

\footnotetext{
${ }^{11}$ A câmara alta compartilha do mesmo princípio, mas é que nem sempre a fonte de poder dos senadores é eletiva.

12 A ênfase é minha.
} 
clarado o vencedor. Um regime democrático para ser aceito como tal precisa realizar de forma concreta, no mínimo, estes dois princípios. ${ }^{13}$

Uma das consequiências do também chamado modelo Westminster - numa referência ao nome da casa do parlamento britânico -, é que ele pode gerar o governo da maior minoria - se o grupo vencedor não atingir a maioria absoluta do eleitorado -, com prevalência sobre os votos das menores minorias que somados, resultaria na maioria do eleitorado. Esta seria uma forma de problematizar este modelo, mostrando-o não tão democrático assim.

Para Lijphart, "a interpretação majoritária da definição básica de democracia é que esta significa 'governo pela maioria do povo'. Ela afirma que as maiorias devem governar e que as minorias devem fazer oposição. (...) O governo pela maioria e o padrão 'governo versus oposição', que este pressupõe, podem ser interpretados como antidemocráticos, por se tratar de princípios de exclusão. O principal pressuposto da democracia é que todos aqueles afetados por uma decisão devem ter a oportunidade de participar do processo que a originou, quer diretamente, quer através de representantes escolhidos. Sua segunda implicação é que a vontade da maioria deve prevalecer. Se isto quer dizer que os partidos vitoriosos podem tomar todas as decisões governamentais, e que os perdedores devem limitar-se a criticar, porém não a governar, os dois significados são incompatíveis: excluir grupos perdedores da participação nos processos decisórios é uma nítida violação do principal pressuposto da democracia. (...) [Teríamos o chamado] 'governo pelo povo””. (Idem, 2003:51).

Mesmo neste padrão de situação governa, oposição critica, existe um campo aberto para que os grupos perdedores possam fazer valer a sua voz e/ou os seus interesses. Se a situação governa para todos ela, em tese, tem de ouvir e levar em conta, as demandas da oposição. Seria o que Lijphart chama de um 'governo para o povo'. Além disso dependerá do desenho institucional, das regras constitucionais, do número de partidos, da forma de divisão interna do Estado, e do horizonte eleitoral, que pode recolocar a oposição de hoje, no governo amanhã.

Lijphart não deixa de indicar este último motivo, o das eleições, além de afirmar também que nas sociedades mais homogêneas, por seus partidos não apresentarem divergências profundas,

\footnotetext{
${ }^{13}$ É possível dizer que o primeiro está vinculado à extensão do voto (sufrágio universal) e o segundo aos grupos políticos que disputam o poder. Ou seja, as duas dimensões da poliarquia, tal como formulada por Robert Dahl (1972 [1997]).
} 
eles se mantém em uma posição de centro no espectro ideológico. Neste cenário o modelo majoritário teria mais chance de canalizar e estruturar as demandas dos grupos políticos.

Stepan parece não considerar que nas democracias majoritárias o demos poderia ser restrito, caso ele representasse a maior minoria eleita e não a maioria absoluta do eleitorado. Assim, mesmo em uma democracia majoritária unitária existiria a possibilidade do demos sofrer restrições mas, curiosamente, estando localizado fora do governo que o representa. Então, não seria apenas o federalismo o único responsável pelo potencial de restrição ao governo do centro mas também o modelo de democracia adotado.

É interessante observar que se para Stepan o federalismo limita o poder do centro, para os federalistas o intuito foi outro ao defenderem a adoção da federação nos Estados Unidos. James Madison n'Os Artigos Federalistas interpretou a formação da Constituição americana como fortalecedora do governo nacional, restringindo, desta forma, o poder das maiorias regionalmente localizadas, tendo como foco o poder excessivo dos legislativos estaduais. O objetivo foi dotar o governo nacional de instrumentos institucionais e políticos para melhor governar o país, que estava muito disperso. Como observa King (1982), os federalistas defenderam o fortalecimento do centro, mas com mecanismos de equilíbrio, como os freios e contrapesos, baseados na separação dos poderes e, mais importante, numa base de representação popular.

Nota-se duas visões sobre o poder das maiorias. A de Stepan prioriza a representação, baseada numa visão majoritária da democracia. Assim, uma federação enfraquece o poder do centro, pois ele é dividido - ou contrabalançado - com os poderes alocados regionalmente. E a de Madison enfoca os mecanismos institucionais capazes de tornar o Executivo nacional mais capaz frente aos poderes alocados nos estados. E, por extensão, haveria um enfraquecimento dos interesses de maiorias alocadas regionalmente.

É preciso considerar também o quanto uma sociedade está dividida quanto a seus objetivos politicos e sua identidade como nação. Talvez a maior crítica para a adoção do modelo majoritário seja nos países com problemas de nacionalidade, tais como língua, religião e etnia. Para Lijphart, em sociedades multinacionais, "as medidas políticas defendidas pelos principais partidos tendem a divergir de modo mais intenso e, freqüentemente, a fidelidade dos eleitores é mais rígida, reduzindo as chances de que os pricipais partidos venham a alternar-se no poder.” (Ibidem, 2003:52). Nestas sociedades é provável que esteja ausente - ou seja mais difícil - uma flexibilidade necessária, caso 
ela adote o modelo majoritário. Poderia ser vivenciada a chamada tirania da maioria. Pois, "sob tais condições, a prevalência da regra da maioria não apenas será antidemocrática, mas também perigosa, uma vez que as minorias que têm seu acesso ao poder sistematicamente negado irão sentir-se excluídas e discriminadas, podendo perder o senso de lealdade ao regime”. (Ibidem, 2003:52). ${ }^{14}$

Ao invés, especialmente em estados multinacionais, seria adequado um tipo de regime democrático que incluísse as minorias, estimulasse o consenso e não a oposição. Desta forma seria possível ampliar a maioria governante, em vez de se satisfazer com uma pequena maioria ou mesmo uma maior minoria. Este seria o princípio básico do chamado modelo consociativo de democracia, defendido especialmente por Lijphart. E que poderia ser adotado também para países menos divididos, mais homogêneos, ainda que com peculiaridades de heterogeneidades outras, como de fundo socioeconômico, por exemplo.

Em suma, o ponto fulcral do modelo consensual é a prevalência da vontade da maior parte das pessoas. Não difere substancialmente do princípio do modelo majoritário, ao concordar que o governo da maioria é melhor do que o da minoria. O que os diferem é que o consociativismo considera a exigência de uma maioria como um requisito mínimo. Nos dizeres de Lijphart, "em vez de se satisfazer com mínimas maiorias, ele busca ampliar o tamanho das mesmas. Suas regras e instituições visam a uma ampla participação no governo e a um amplo acordo sobre as políticas que este deve adotar. O modelo majoritário concentra o poder político nas mãos de uma pequena maioria, e muitas vezes, mesmo, de uma maioria simples (plurality), em vez de uma maioria absoluta ao passo que o modelo consensual tenta compartilhar, dispersar e limitar o poder de várias maneiras. Uma outra diferença, relacionada a esta última, é que o modelo majoritário de democracia é exclusivo, competitivo e combativo, enquanto o modelo consensual se caracteriza pela abrangência, a negociação e a concessão." (Ibidem, 2003:18).

Tudo bem, estas características, digamos, valorativas, os diferenciam, mas é preciso qualificar os casos concretos, além de considerar que os modelos não são puros e que estes atributos encontrados em um, podem eventualmente ser identificados em um outro modelo também, a depender de uma configuração institucional específica e dos objetivos dos grupos políticos que agem sobre um determinado contexto.

\footnotetext{
${ }^{14}$ Esta situação também pode ser vivenciada nos casos de sistemas políticos que impedem ou tornam muito difícil a alternância no poder, mesmo dentro das regras democráticas, podendo levar à ameaça de manutenção da democracia. Ver Linz e Stepan (1999).
} 
Pois se Stepan argumenta que as federações democráticas têm uma característica de restrição ao poder do centro (que representa o demos), baseado no modelo majoritário, é preciso ponderar que ao considerarmos esta mesma federação sob um ponto de vista consociativo, esta pretensa restrição precisa ser melhor refletida. Pois nesta visão o federalismo não é necessariamente - ou sempre - um demolimitador. Pode ser visto como um ampliador dos vários demoi que somados compõe o demos. Uma sociedade que adota a forma federada, tem em mente a divisão, a dispersão, a limitação de uma autoridade central, porque vê a sociedade como eminentemente variada em seus objetivos, ainda que assentadas em bases e motivações alocadas de forma politicamentre territorial. Talvez esta territorialidade como fonte de representação política é o que cause questionamento pois, como já apontado, os interesses políticos não estão somente concentrados em termos espaciais, mas sim difusos entre todas as unidades políticas que formam uma federação, sejam as de caráter regional, seja a de caráter nacional. Pois se estamos pensando as federações em regimes democráticos este elemento é central para as características de representação de um sistema político. ${ }^{15}$

Mesmo ressaltando as virtudes de um sistema mais aberto à diversidade dos grupos de poder no interior do território, seja por motivos culturais e/ou de extensão geográfica, King (1993) qualifica a democracia em federações como 'incompleta', pois violaria o princípio básico da igualdade de voto entre os cidadãos. Para ele o que é distintivo numa federação é "a forma como está assegurada a soberania da representação legislativa federal da população, mais do que qualquer processo de decisão judicial ou do poder executivo." (King, 1993:95). Isso porque, o princípio da igualdade dos cidadãos estaria 'desgastado' onde a igualdade de representação estivesse misturada em duas fontes distintas, a da câmara baixa e da câmara alta. Pois, "numa democracia o princípio básico é o direito do cidadão votar em bases iguais. Numa federação, vista como um tipo particular de democracia, é distintivo que a representação de regiões é de alguma maneira entrelaçada. Nas federações é adequado e desejável que tais sistemas não estabeleçam de forma clara que eles incorporam (necessária e inevitavelmente) algum grau de desigualdade entre os cidadãos das diferentes regiões." (Idem, 1993:100-101). Ou seja, se a democracia em federações concebe um tipo especial de representação (o consociativo), ele teria de ser o menos desigual possível.

\footnotetext{
${ }^{15}$ E esta questão da representação alocada nas subunidades territoriais é, afinal, constituinte do modo de ser de uma federação, não apenas por razões de ordem nacionalista, mas também por causa do tamanho do país. Uma das características mais comuns nas federações é a relação que estabelece com o tamanho do território. Assim, a maior parte dos países com grandes extensões físicas estão organizados na forma federativa. A razão mais apontada para a adoção é a suposta facilidade maior de administração do país em seu conjunto, vasto em proporções e com recursos naturais e/ou populacionais espalhados. As chamadas federações mononacionais - ou seja sem grandes recortes culturais internos -, se encaixariam em geral nesta peculiaridade. Países como Argentina, Austrália, Brasil e Estados Unidos, entre outros. E podemos lembrar também de países como o Canadá, Índia e Rússia, de grande território e recorte multinacional.
} 
Por esta via, poderíamos estabelecer uma aproximação com o argumento de Stepan, no qual as federações demos enabling seriam mais democráticas? Ora, mas este diálogo dos dois autores está baseado no modelo majoritário de democracia, que prioriza o interesse do governo nacional sobre os governos regionais.

Pois se uma federação é um arranjo institucional que demarca um tipo 'especial'de divisão e representação do poder, procurando antes incluir do que excluir, o tal demos constraining não seria, necessariamente, anti-democrático, mas antes voltado à busca da estabilidade e do consenso dentro de um sistema político. Poderíamos dizer que esta maior dificuldade de mudança do status quo gera decisões políticas mais compartilhadas entre o demos e os demoi e, por extensão, entre o governo e a oposição, tanto em nível nacional, como regional. Uma das dificuldades apontadas para os sistemas unitários, inclusive, é sua maior rigidez decisória, ou seja, um nível de governo hierarquicamente mais poderoso que os demais - do nacional para o regional -, o que poderia provocar mais instabilidade nas políticas aplicadas e na própria manutenção do regime político ou na união do país como um único Estado.

Stepan, assim como outros autores já discutidos neste texto, observa que existem mecanismos constitucionais que protegem as minorias nas federações. Em suas palavras: "Para evitar que o povo ou demos aprove leis majoritárias que poderiam violar os direitos das minorias, por exemplo, quase todas as democracias modernas têm uma Constituição que protege os direitos fundamentais dos cidadãos enquanto indivíduos e uma suprema corte com a prerrogativa constitucional de declarar nulas e sem efeito leis aprovadas pela legislatura caso, segundo a opinião da corte, tais leis violem a Constituição”. (Stepan, 2002:274). O que está embutido em seu argumento é que se as minorias já estão 'protegidas', as federações não precisariam concentrar tantos recursos de poder em suas unidades regionais.

O que ocorre é que Stepan se concentra prioritariamente nas restrições baseadas na representação, mas numa federação a fonte de poder - difuso por definição -, das unidades regionais não se localiza apenas neste aspecto, mas como aponta o mesmo autor - ao apresentar as variáveis três e quatro - também nos seus poderes executivo e legislativo, além das características do sistema de partidos. 


\section{Conclusões}

Vimos neste texto uma ampla consideração sobre as relações políticas e institucionais da democracia com um tipo particular de divisão de poder interno, o federalismo. A começar das dificuldades em defini-lo e das diferentes formas em que ele se originou e desenvolveu-se, ora mais voltados ao fortalecimento de uma união interna contra agressões externas, ora com questões nacionalistas.

E para além destas distinções, o regime político democrático seria uma garantia ao pleno funcionamento e manutenção de uma federação. Assim é que Stepan procura recolocar o tema do federalismo dentro do debate de uma teoria da democracia, ao analisar principalmente quais as características das democracias federativas. Mas a partir de uma concepção própria de democracia - a majoritária - e dos efeitos que o federalismo opera no sentido de torná-la mais ou menos efetiva.

Só é possível que concordemos com o argumento de Stepan se nos vincularmos totalmente à concepção de democracia que ele defende. Aquela da igualdade estrita do voto e da regra da maioria, do vencedor leva tudo, com a oposição perdedora ficando ausente do poder. Nesse sentido, Stepan poderia ser classificado como um intérprete anti-federalista do federalismo.

Um modelo de democracia contrário ao majoritário é defendido por Lijphart, o consociativo. Este, em princípio não discorda dos princípios majoritários, principalmente o da vitória da maioria que vence uma disputa eleitoral. Mas concebe a democracia não em termos de uma maioria simples, mas da maior maioria possível, com o objetivo de incluir no processo político de governo a maior parte dos grupos existentes na sociedade. Dentro desta visão, o federalismo não seria antidemocrático, mas o mais adequado para canalizar politicamente aos vários postos de poder, os diferentes grupos existentes no interior de uma sociedade, especialmente aqueles recortados com problemas graves de identificação e convivência no interior de um mesmo território. Mas este não é o caso de todas as federações. Naquelas com ausência de problemas de ordem nacionalista, o argumento de Stepan é, no mínimo, passível de ser considerado como interessante para a análise de como os grupos estão representados no legislativo federal e se, a partir daí, possa ocorrer situações demos constraining. O caso de países como Argentina, Brasil e Estados Unidos estaria mais próximo deste caso, embora eles também apresentem clivagens internas. No caso brasileiro, por exemplo, elas estariam centradas na desigualdade regional, principalmente de ordem socioeconômica. 
Mas tal clivagem justificaria um desenho institucional que, em tese, poderia vir a restringir o demos?

No fundo o que está no subtexto deste debate entre um federalismo mais nacional ou centralizado (demos enabling) e um federalismo mais regional ou descentralizado (demos constraining) é a relação entre representação e autoridade, entre legitimidade e governo, da fonte do poder com a extensão deste poder no exercício de cada instituição que compõe uma democracia. E em especial, no caso deste capítulo, do federalismo.

Acredito que nesse sentido os constrangimentos apontados por Stepan seguem uma linha de interpretação negativa, de como dificultam a governabilidade do poder Executivo, principalmente em nível nacional. É como se a estrutura institucional prejudicasse o desempenho da democracia quando, ao invés, ela foi criada em conseqüência dela. Pois é dada muita ênfase à capacidade de governar em detrimento da importância da qualidade da representação. E mesmo quando esta é pensada no sentido de ser aperfeiçoada é para melhorar a governabilidade. Numa democracia, creio, a fonte de poder é popular. Portanto, a questão da representação política é a base para um posterior processo de alianças das forças políticas com o intuito de melhor governar um país.

De acordo com este argumento o objetivo seguinte é tentar compreender melhor esta relação entre a representação e a extensão do poder no interior de uma federação, tomando como meio de análise uma das instituições representativas que dão 'garantias' ao seu funcionamento, o bicameralismo. E, mais especificamente, na casa legislativa federativa, a chamada câmara alta. Ou por centrarmos a análise no caso brasileiro, chamando-a pelo seu nome, Senado Federal. 


\section{Capítulo 2}

\section{Representação federativa e o caso brasileiro}

No capítulo anterior discutimos a questão da representação política em federações democráticas e sua dualidade, consagrada no poder Legislativo bicameral, com a câmara baixa representando a população e a câmara alta as unidades territoriais que formam um país em seu conjunto. Desta maneira iremos discutir novamente esta questão, mas sem retornar aos conceitos que já foram abordados. A intenção é avançar, tendo em perspectiva o caso da representação federativa brasileira.

Inicialmente faremos uma breve exposição sobre algumas das principais características do bicameralismo, especialmente com relação aos possíveis efeitos legislativos entre uma câmara e outra e de como elas diferem e são mais ou menos efetivas, a partir da extensão dos seus poderes e dos critérios para a escolha dos seus representantes. Esta seção serve de introdução à questão principal a ser discutida neste capítulo e mesmo nos posteriores, procurando situar o campo analítico em que atuam as duas câmaras legislativas, especialmente para o caso brasileiro.

Tendo por base uma pergunta já problematizada no capítulo um, qual seja, se a câmara alta é uma casa federativa ou anti-democrática, tentaremos entender como esta indagação se aplica ao Senado Federal brasileiro, por meio do perfil de sua representação igualitária, a extensão de suas atribuições e seu poder de veto potencial. E se estas características podem ser discutidas tanto em seus próprios termos, como de maneira mais profícua na relação que estabelece com a Câmara dos Deputados, para averiguarmos como o Senado opera em comparação com a outra câmara, tanto do ponto de vista representativo, como dos poderes das duas casas.

Do ponto de vista da representação faremos uma reflexão sobre os possíveis efeitos da dupla desproporcionalidade existente no Legislativo federal. Este problema, que é recorrente nos regimes democráticos e em especial nos de estrutura federativa, tem bases históricas sólidas no caso do Brasil, pois remonta ainda ao período monárquico, antes até da República e da Federação. Esta é uma característica consociativa para a justificativa de um federalismo existente em um país territorialmente grande e desigual em termos políticos, econômicos e de distribuição de sua população.

Nesse sentido, de que maneira a igualdade representativa no Senado - que produz alta sobrerepresentação a favor das regiões Norte, Nordeste e Centro-Oeste - e a proporcionalidade distorcida 
na Câmara dos Deputados - que favorece a região Norte e prejudica o estado de São Paulo - pode influir nos resultados da legislação produzida pelo Congresso brasileiro?

E nesta questão da equivalência de poderes entre as casas, priorizaremos as propostas de emendas à Constituição, iniciativas que visam a alterá-la. O fato de escolhermos este caminho é que, como veremos, por este meio o Senado, em tese, tem poderes equivalentes de atuação legislativa em relação à Câmara dos Deputados. E além disso as emendas representam uma mudança substantiva, que demanda mais deliberação e busca de consenso.

\section{Características do bicameralismo}

Em geral, a literatura dedicada ao estudo do bicameralismo tem procurado ir além de um argumento convencional de que a existência de uma segunda câmara é vista como tendo pouco impacto sobre o relacionamento entre a legislatura e o poder Executivo. No sistema presidencialista, o Executivo é eleito diretamente e não precisa do apoio político do legislativo para sobreviver. Nos sistemas parlamentaristas, no qual o governo precisa do apoio político do parlamento para manterse, este apoio é medido quase exclusivamente na popularidade da câmara baixa, que é onde geralmente o governo é formado.

George Tsebelis e Jeannete Money (1997) reconhecem que a influência do bicameralismo não é muito fácil de ser percebida, pois a legislação pode ser enviada de uma casa para outra e ser mudada sem que haja sinal de desacordo, mas postulam que, em primeiro lugar, o bicameralismo torna mais difícil a mudança do status quo. Pois se no unicameralismo uma legislação pode ser conseguida por uma maioria simples ou absoluta em um única casa, no bicameralismo é preciso que a maioria seja conseguida em mais de uma casa, sendo que - em alguns casos - ambas podem vir a ter poder de veto, além do governo ter de formar maioria em duas casas, ao invés de uma. Em segundo lugar, o bicameralismo reduz as possibilidades de desacordo entre os legisladores, ou dos partidos nas câmaras para uma dimensão privilegiada, que tem de ser acordada entre eles. Terceiro, a existência de uma segunda câmara muda os efeitos legislativos mesmo que esta câmara não tenha poder de veto, e mesmo se elas são politicamente similares à primeira câmara. Finalmente, as instituições que regulam a resolução de controvérsias entre as duas câmaras afetam os resultados legislativos. Os autores sintetizam: “as instituições bicamerais reduzem o 'ciclo' de problemas associados com as legislaturas unicamerais. (...) [Pois] dividindo a legislatura em dois grupos distintos e requerendo maiorias concorrentes de ambos os grupos, eles podem reduzir o número de alternativas que uma maioria prefere.” (Tsebelis e Money, 1997:38-39). 
Além desses fatores, a mera presença de uma segunda câmara cria a possibilidade de um controle de qualidade ou de temperança sobre uma dada decisão política. Este controle em primeiro lugar é preventivo, pois sabendo que alguma coisa será examinada, quem a produziu tomará mais cuidado. Em em segundo lugar, existe um sistema para corrigir eventuais erros depois que eles tenham sido cometidos. Em suma, é uma casa que se constitui fundamentalmente para revisar as decisões da câmara baixa.

Para tornar mais claro em termos conceituais como as diferenças entre as duas câmaras são importantes, recorramos ao trabalho de Lijphart (2003). Assim, existem seis diferenças básicas entre as câmaras legislativas (a baixa e a alta), subdivididas em dois conjuntos de três, as menos e as mais importantes, no sentido de determinar a importância institucional do bicameralismo.

A primeira é que as câmaras altas têm menos membros que as câmaras baixas, com variações quanto ao tamanho maior ou menor de cada um. No Brasil, por exemplo, temos 513 deputados federais e 81 senadores.

A segunda é que os mandatos nas câmaras altas tendem a ser mais longos. Os períodos nas câmaras baixas oscilam entre dois e cinco anos e os das câmaras altas, de quatro a nove anos. No Brasil, temos quatro anos para os deputados e oito para os senadores.

A terceira é a eleição de forma alternada da câmara alta. Ou seja, geralmente na metade do mandato, há uma renovação de metade ou um terço do número de membros. No Brasil, temos eleições de quatro em quatro anos, renovando em uma rodada um terço e na outra dois terços. Isso porque, temos três senadores por estado.

Já as características mais importantes do ponto de vista institucional estariam relacionadas com a força ou fraqueza do bicameralismo. Entre elas o primeiro aspecto consistiria nos poderes constitucionais formais de que dispõem as duas câmaras. O padrão geral é que as câmaras altas costumam ser subordinadas às câmaras baixas. O Brasil, ao lado de países também federais como os Estados Unidos e a Suíça e unitários, como a Colômbia e a Itália, estariam entre aqueles em que os poderes das duas câmaras seriam aproximadamente iguais.

Um segundo aspecto institucional relevante estaria relacionado com o método de seleção dos membros. Todas as câmaras baixas dos países democráticos são eleitas pelo voto direto dos eleitores, 
porém, na maior parte das câmaras altas são eleitos de forma parcial ou integralmente indireta, com um índice expressivo de $63,16 \% .{ }^{16} \mathrm{O}$ argumento geral é que os senados não eleitos diretamente carecem de legitimidade democrática para a tomada de decisões, vindo daí a influência política da eleição popular. Ao contrário, a eleição direta na câmara alta pode, até certo ponto, compensar seu poder limitado, em termos constitucionais.

Tendo por base estes dois critérios os poderes constitucionais formais e a legitimidade democrática, os bicameralismos podem ser classificados como simétricos ou assimétricos. "Câmaras simétricas são aquelas que dispõem de poderes constitucionais iguais, ou apenas moderadamente desiguais, e de legitimidade democrática. As câmaras assimétricas são extremamente desiguais nesses aspectos." (Lijphart, 2003:235).

Já o terceiro aspecto importante - e o sexto no conjunto -, é que as câmaras altas podem ser eleitas por métodos diferentes, ou com o objetivo de sobre-representar certas minorias. Se assim for, as duas câmaras diferem em sua composição, e podem ser chamadas de incongruentes. Os exemplos mais recorrentes são daquelas câmaras altas que atuam como câmaras federais e sobre-representam as menores unidades componentes de uma federação, especialmente quando existe igualdade de representação.

Desta forma, Lijphart estipula três categorias principais para o bicameralismo. O bicameralismo forte, o meio-forte - ou moderado - e o fraco. "O bicameralismo forte caracteriza-se tanto pela simetria quanto pela incongruência. No bicameralismo meio-forte, falta um desses dois elementos. Essa categoria é dividida em duas subclasses, na dependência de ser a simetria ou a incongruência o elemento que falta. (...) A terceira categoria é o bicameralismo fraco, no qual as câmaras são tanto assimétricas quanto congruentes." (Idem, 2003:239). ${ }^{17}$

\footnotetext{
${ }^{16}$ Porcentual calculado a partir da Tabela 1.1 de Samuel Patterson e Anthony Mughan, 1999a:6-8.

${ }^{17} \mathrm{Na}$ verdade, Lijphart inclui o unicameralismo como uma quarta categoria. Mas é um equívoco, já que não há duas câmaras para serem comparadas.
} 
Em resumo:

\begin{tabular}{|l|c|c|}
\hline & CONGRUÊNCIA & INCONGRUÊNCIA \\
\hline SIMETRIA & Meio-Forte & Forte \\
\hline ASSIMETRIA & Fraco & Meio-Forte \\
\hline
\end{tabular}

Na maior parte dos países federativos, o bicameralismo se caracteriza pela simetria de poder com incongruência de representação (forte) ou assimetria de poder com incongruência de representação (meio-forte). O mais relevante no caso presente é de que forma, a partir desta, digamos, tipologia, podemos entender o caso do bicameralismo brasileiro. Stepan (1999) e Mariana Llanos (2002) defendem que o caso brasileiro seria o de um bicameralismo simétrico e incongruente. Se do ponto de vista da representação não há o que discordar, em relação à força de ambos no exercício do processo legislativo o ponto não é tão claro, como procuraremos mostrar.

\section{Representação federativa no caso brasileiro}

Os estudos sobre os diferentes tipos de sistemas eleitorais têm mostrado que todos eles apresentam níveis de desproporcionalidade em sua representação para a câmara baixa. Não há uma tradução democrática entre a proporção dos habitantes de um distrito e seu respectivo número de representantes. Lijphart (2003) afirma que este problema é mais acentuado nos sistemas eleitorais majoritários em governos parlamentaristas e majoritários e proporcionais nos governos presidencialistas. Ou seja, o parlamentarismo baseado em um sistema eleitoral proporcional seria o que sofreria menos com este

problema. Subentende-se, então, que a questão da distribuição dos representantes de acordo com a população de seu distrito teria a ver tanto com as características dos sistemas eleitorais, como do sistema de governo ou com o tipo de divisão interna de um estado.

Em todo caso, como já discutimos no capítulo anterior, esta questão nos remete ao modelo de democracia que um dado país adota, se de perfil mais majoritário ou consociativo. E esta decisão está vinculada a razões diversas, como desde a formação original de um país, até o grau de heterogeneidade cultural existente no seu interior. Nesse sentido, as federações estariam mais próximas do modelo consociativo e por adotar o sistema bicameral, teriam de conjugar em seus critérios de representação duas fontes distintas, uma mais eminentemente majoritária e outra consociativa. A primeira relacionada à representação da população na câmara baixa - proporcional à população de cada distrito eleitoral -, e a segunda à representação das unidades políticas internas que formam o conjunto da federação, na câmara alta - de representação igualitária, na maior parte dos casos. Teríamos assim, a equivalência 
do princípio 'uma pessoa, um voto' para 'um estado, um voto', o que estabeleceria uma certa tensão entre dois princípios diferentes, em nome de uma sociedade mais diversificada, como uma federação.

Pois se esta dualidade é compreensível e justificável não haveria, teoricamente, uma razão normativa para a existência de desproporcionalidade na câmara baixa, pois caberia a ela contrapor a sobre-representação da câmara alta. Contudo, os sistemas eleitorais têm estabelecido uma representação proporcional imperfeita na câmara baixa duplicando, por assim dizer, a questão da sobrerepresentação.

Nesse sentido, vamos observar como está representada a população brasileira na Câmara dos Deputados e os estados no Senado Federal. O número total de deputados federais é, como já visto, de 513, alocados de acordo com o número de representantes específicos de cada unidade federativa (estado), baseados em sua população. Porém, não tem existido um mecanismo de revisão do número de representantes por causa da mudança populacional de cada estado o que, somado ao número mínimo de oito (piso) e o máximo de 70 (teto), confere à Câmara um grau de desproporcionalidade, prejudicando especialmente o estado mais populoso, São Paulo, com um déficit de 42 representantes. (Nicolau, 1997; Oliveira, 2004; Soares e Lourenço, 2004). ${ }^{18}$

\footnotetext{
${ }^{18}$ Arlindo Fernandes de Oliveira (2004) explica que não tem havido uma mudança no número de representantes por cada estado a cada nova eleição, por causa das discussões na Assembléia Nacional Constituinte sobre a criação do estado de Tocantins. É que Goiás protestou que seria prejudicado. "Por esse motivo, em negociação política, foi acrescido ao Ato das Disposições Constitucionais Transitórias, o $\S 2^{\circ}$ do art. $4^{\circ}$, pelo qual é assegurada a irredutibilidade da atual representação dos Estados e do Distrito Federal na Câmara dos Deputados. [grifo do autor]. Embora o legislador constituinte tenha inscrito esse dispositivo no ADCT, para torná-lo aplicável apenas à eleição subseqüente, de tal maneira que os parlamentares goianos aceitassem a criação do estado de Tocantins, o Tribunal Superior Eleitoral conferiu a esse texto a condição de norma permanente, o que engessou a representação de todos os estados na Câmara e converteu em letra morta a competência que a Constituição e a Lei Complementar n. 78, de 1993, conferem ao próprio TSE para, com base em dados fornecidos pelo IBGE, alterar, um ano antes das eleições, o número de representantes de cada estado na Câmara dos Deputados." (Oliveira, 2004:35).
} 
Tabela 2.1 - Representação dos Estados na Câmara dos Deputados.

\begin{tabular}{|c|c|c|c|c|c|c|c|}
\hline Estados & $\begin{array}{c}\text { População } \\
\text { (2005) }\end{array}$ & $\begin{array}{c}\text { \% em re- } \\
\text { lação ao } \\
\text { total da } \\
\text { população } \\
\text { do país }\end{array}$ & $\begin{array}{c}\text { Representação } \\
\text { Atual (A) }\end{array}$ & $\begin{array}{c}\% \text { em } \\
\text { relação } \\
\text { a A } \\
\text { (A') }\end{array}$ & $\begin{array}{c}\text { Representação } \\
\text { Proporcional } \\
\text { (B) }\end{array}$ & $\begin{array}{c}\% \text { em } \\
\text { relação } \\
\text { a B } \\
\left(B^{\prime}\right)\end{array}$ & $\begin{array}{c}\text { Diferença } \\
\text { (A-B) }\end{array}$ \\
\hline Acre & 669.736 & 0,36 & 8 & 1,55 & 2 & 0,39 & +6 \\
\hline Amazonas & 3.232 .330 & 1,75 & 8 & 1,55 & 9 & 1,75 & -1 \\
\hline Amapá & 594.587 & 0,32 & 8 & 1,55 & 1 & 0,19 & +7 \\
\hline Pará & 6.970 .586 & 3,78 & 17 & 3,31 & 19 & 3,70 & -2 \\
\hline Rondônia & 1.534 .594 & 0,83 & 8 & 1,55 & 4 & 0,78 & +4 \\
\hline Roraima & 391.317 & 0,21 & 8 & 1,55 & 1 & 0,19 & +7 \\
\hline Tocantins & 1.305 .728 & 0,71 & 8 & 1,55 & 4 & 0,78 & +4 \\
\hline $\begin{array}{l}\text { Região } \\
\text { Norte }\end{array}$ & 14.698 .878 & 7,98 & 65 & 12,67 & 40 & 7,80 & +25 \\
\hline Alagoas & 3.015 .912 & 1,64 & 9 & 1,75 & 9 & 1,75 & 0 \\
\hline Bahia & 13.815 .334 & 7,50 & 39 & 7,60 & 40 & 7,79 & -1 \\
\hline Ceará & 8.097 .276 & 4,40 & 22 & 4,29 & 22 & 4,29 & 0 \\
\hline Maranhão & 6.103 .327 & 3,31 & 18 & 3,51 & 17 & 3,31 & +1 \\
\hline Paraíba & 3.595 .886 & 1,95 & 12 & 2,34 & 10 & 1,95 & +2 \\
\hline Pernambuco & 8.413 .593 & 4,57 & 25 & 4,87 & 24 & 4,68 & +1 \\
\hline Piauí & 3.006 .885 & 1,64 & 10 & 1,95 & 9 & 1,95 & +1 \\
\hline $\begin{array}{l}\text { Rio Grande } \\
\text { do Norte }\end{array}$ & 3.003 .087 & 1,63 & 8 & 1,55 & 8 & 1,55 & 0 \\
\hline Sergipe & 1.967 .791 & 1,07 & 8 & 1,55 & 5 & 0,97 & +3 \\
\hline $\begin{array}{l}\text { Região } \\
\text { Nordeste }\end{array}$ & 51.019 .091 & 27,70 & 151 & 29,43 & 144 & 28,07 & +7 \\
\hline $\begin{array}{l}\text { Distrito Fe- } \\
\text { deral }\end{array}$ & 2.333 .108 & 1,27 & 8 & 1,55 & 6 & 1,17 & +2 \\
\hline Goiás & 5.619 .917 & 3,05 & 17 & 3,31 & 15 & 2,92 & +2 \\
\hline $\begin{array}{l}\text { Mato Gros- } \\
\text { so }\end{array}$ & 2.803 .274 & 1,52 & 8 & 1,55 & 8 & 1,55 & 0 \\
\hline
\end{tabular}




\begin{tabular}{|l|c|c|c|c|c|c|c|}
\hline $\begin{array}{l}\text { Mato Gros- } \\
\text { so do Sul }\end{array}$ & 2.264 .468 & 1,23 & 8 & 1,55 & 6 & 1,17 & +2 \\
\hline $\begin{array}{l}\text { Região } \\
\text { Centro- } \\
\text { Oeste }\end{array}$ & $\mathbf{1 3 . 0 2 0 . 7 6 7}$ & $\mathbf{7 , 0 7}$ & $\mathbf{4 1}$ & $\mathbf{7 , 9 9}$ & $\mathbf{3 5}$ & $\mathbf{6 , 8 2}$ & $\mathbf{+ 6}$ \\
\hline $\begin{array}{l}\text { Espírito } \\
\text { Santo }\end{array}$ & 3.408 .365 & 1,85 & 10 & 1,95 & 9 & 1,75 & +1 \\
\hline $\begin{array}{l}\text { Minas Ge- } \\
\text { rais }\end{array}$ & 19.237 .450 & 10,44 & 53 & 10,33 & 54 & 10,53 & -1 \\
\hline $\begin{array}{l}\text { Rio de Ja- } \\
\text { neiro }\end{array}$ & 15.383 .407 & 8,35 & 46 & 8,97 & 43 & 8,38 & +3 \\
\hline São Paulo & 40.442 .795 & 21,96 & 70 & 13,64 & 112 & 21,83 & -42 \\
\hline $\begin{array}{l}\text { Região Su- } \\
\text { deste }\end{array}$ & $\mathbf{7 8 . 4 7 2 . 0 1 7}$ & $\mathbf{4 2 , 6 0}$ & $\mathbf{1 7 9}$ & $\mathbf{3 4 , 8 9}$ & $\mathbf{2 1 8}$ & $\mathbf{4 2 , 5 0}$ & $\mathbf{- 3 9}$ \\
\hline Paraná & 10.261 .856 & 5,57 & 30 & 5,85 & 29 & 5,65 & +1 \\
\hline $\begin{array}{l}\text { Rio Grande } \\
\text { do Sul }\end{array}$ & 10.845 .087 & 5,89 & 31 & 6,04 & 31 & $\mathbf{6 , 0 4}$ & 0 \\
\hline $\begin{array}{l}\text { Santa Cata- } \\
\text { rina }\end{array}$ & 5.866 .568 & 3,19 & 16 & 3,12 & 16 & 3,12 & 0 \\
\hline Região Sul & $\mathbf{2 6 . 9 7 3 . 5 1 1}$ & $\mathbf{1 4 , 6 4}$ & $\mathbf{7 7}$ & $\mathbf{1 5 , 0 1}$ & $\mathbf{7 6}$ & $\mathbf{1 4 , 8 1}$ & $\mathbf{+ 1}$ \\
\hline $\begin{array}{l}\text { Total } \\
\mathbf{1 8 4 . 1 8 6 . 2 6 4}\end{array}$ & $\mathbf{1 0 0 , 0 0}$ & $\mathbf{5 1 3}$ & $\mathbf{1 0 0 , 0 0}$ & $\mathbf{5 1 3}$ & $\mathbf{1 0 0 , 0 0}$ & $\mathbf{0}$ \\
\hline
\end{tabular}

Fontes: Elaboração própria a partir do site do Instituto Brasileiro de Geografia e Estatística (www.ibge.br) e Soares e Lourenço, 2004.

A tabela acima nos mostra como estão representados em termos numéricos os 26 estados da federação mais o Distrito Federal, divididos em suas respectivas regiões. A análise em pormenor da situação de cada um dos estados e das regiões em particular não é o nosso interesse aqui, mesmo porque já existem trabalhos sobre isso, principalmente nos últimos anos (Nicolau, 1997; Oliveira, 2004; Soares e Lourenço, 2004).

Cabe destacar o principal, contudo, que é o alto grau de sobre-representação da região Norte com cerca de apenas $8 \%$ da população nacional - que deveria ter 25 deputados a menos $(4,88 \%$ a 
mais do correto) e a sub-representação na região Sudeste - com expressivos 42,6\% da população, quase a metade do país -, que deveria ter 39 deputados a mais (7,90\% a menos do que o correto). No primeiro caso, a alta desproporção concentra-se nos estados com baixa população, o Acre, Amapá, Rondônia, Roraima e Tocantins, que juntos têm 28 deputados a mais, com apenas 6,8\% da população brasileira. Já na região Sudeste, o problema está concentrado em um único estado, São Paulo, que concentra quase $22 \%$ da população do país, com a já citada falta de 42 deputados (menos 8,19\% do correto).

Tabela 2.2 - Representação dos Estados no Senado Federal.

\begin{tabular}{|l|c|c|c|}
\hline Estados & $\begin{array}{c}\text { População } \\
\mathbf{( 2 0 0 5 )}\end{array}$ & $\begin{array}{c}\text { \% em relação ao } \\
\text { total da população } \\
\text { do país }\end{array}$ & Representantes \\
\hline Acre & 669.736 & 0,36 & 3 \\
\hline Amazonas & 3.232 .330 & 1,75 & 3 \\
\hline Amapá & 594.587 & 0,32 & 3 \\
\hline Pará & 6.970 .586 & 3,78 & 3 \\
\hline Rondônia & 1.534 .594 & 0,83 & 3 \\
\hline Roraima & 391.317 & 0,21 & 3 \\
\hline Tocantins & 1.305 .728 & 0,71 & $\mathbf{2 1}(\mathbf{2 5 , 9 2 \% )}$ \\
\hline Região Norte & $\mathbf{1 4 . 6 9 8 . 8 7 8}$ & $\mathbf{7 , 9 8}$ & 3 \\
\hline Alagoas & 3.015 .912 & 1,64 & 3 \\
\hline Bahia & 13.815 .334 & 7,50 & 3 \\
\hline Ceará & 8.097 .276 & 4,40 & 3 \\
\hline Maranhão & 6.103 .327 & 3,31 & 3 \\
\hline Paraíba & 3.595 .886 & 1,95 & $\mathbf{2 7}$ \\
\hline Pernambuco & 8.413 .593 & 4,57 & 3 \\
\hline Piauí & 3.006 .885 & 1,64 & 3 \\
\hline Rio Grande do & 3.003 .087 & 1,63 & 3 \\
\hline Norte & & & 3 \\
\hline Sergipe & $\mathbf{5 1 . 0 1 9 . 0 9 1}$ & $\mathbf{2 7 , 7 0}$ & 3 \\
\hline Região Nordeste & & 3 \\
\hline
\end{tabular}

\footnotetext{
${ }^{19}$ Esta é a porcentagem de senadores por região em relação ao número total da casa.
} 


\begin{tabular}{|c|c|c|c|}
\hline Distrito Federal & 2.333 .108 & 1,27 & 3 \\
\hline Goiás & 5.619 .917 & 3,05 & 3 \\
\hline Mato Grosso & 2.803 .274 & 1,52 & 3 \\
\hline $\begin{array}{l}\text { Mato Grosso do } \\
\text { Sul }\end{array}$ & 2.264 .468 & 1,23 & 3 \\
\hline $\begin{array}{l}\text { Região Centro- } \\
\text { Oeste }\end{array}$ & 13.020 .767 & 7,07 & $12(14,81 \%)$ \\
\hline Espírito Santo & 3.408 .365 & 1,85 & 3 \\
\hline Minas Gerais & 19.237 .450 & 10,44 & 3 \\
\hline Rio de Janeiro & 15.383 .407 & 8,35 & 3 \\
\hline São Paulo & 40.442 .795 & 21,96 & 3 \\
\hline Região Sudeste & 78.472.017 & 42,60 & $12(14,81 \%)$ \\
\hline Paraná & 10.261 .856 & 5,57 & 3 \\
\hline Rio Grande do Sul & 10.845 .087 & 5,89 & 3 \\
\hline Santa Catarina & 5.866 .568 & 3,19 & 3 \\
\hline Região Sul & 26.973 .511 & 14,64 & $9(11,12 \%)$ \\
\hline Total & 184.186 .264 & 100,00 & $81(100 \%)$ \\
\hline
\end{tabular}

Fontes: Elaboração própria a partir do site do Instituto Brasileiro de Geografia e Estatística (www.ibge.br) e Soares e Lourenço, 2004.

O Senado, como já vimos, é constituído por 81 representantes eleitos por maioria simples, três por estado e pelo Distrito Federal, com mandato de oito anos, duas legislaturas, com renovação por um terço e dois terços a cada quatro anos. Aqui também existe desproporcionalidade, devido à representação igualitária de todas as unidades da federação, independentemente de características díspares como, por exemplo, população e tamanho do território.

Já que o Brasil é uma federação e o Senado tem por função representar os estados de forma paritária, em princípio não haveria maiores razões para nos deter na tabela acima. Como ressalta Ana Backes (1998), a força deste raciocínio normativo é tão grande em nosso pensamento institucional, que tem impedido que se examine mais de perto, primeiro as funções que de fato exerce o Senado - inclusive as de caráter não-federativo - e em segundo, que se possa questionar se a subrepresentação da população de alguns estados no Senado não venha a ter repercussões negativas sobre a tomada de decisões que representem a vontade da maioria da população do país. 
Em termos de distribuição da população e da concentração da riqueza, é comum a clivagem entre as três regiões menos populosas e mais pobres - Norte, Nordeste e o Centro-Oeste (com participação no PIB de 25,1\%) - , e as duas regiões mais desenvolvidas e populosas, o Sudeste e o Sul (com uma participação no PIB de 74,9\%). ${ }^{20}$ As três primeiras regiões tem 60 representantes sob uma base populacional de $42,75 \%$ e as outras duas regiões 21 representantes em relação a 57,24\%. ${ }^{21}$

Isso porque, em termos históricos, o problema principal é de povoamento, quer dizer, uma profunda concentração populacional no Sul e no Sudeste, mediana no Nordeste e pálida no CentroOeste e no Norte e que provoca efeitos na distribuição de riqueza entre as regiões. Aqui se coloca em relevância a problemática da distribuição do poder político em termos regionais. Não é um problema contemporâneo, é da história brasileira ainda no tempo do Império, a grande desigualdade de poder entre as regiões.

Uma das razões aventadas para a dupla desproporcionalidade de representação no Congresso Nacional é que ela diminuiria a fraqueza das regiões mais subdesenvolvidas e menos povoadas com relação às de maior desenvolvimento econômico e de maior população. Argumento historicamente questionável por, entre outras razões, não ter permitido de fato um maior equilíbrio nas decisões políticas no país, concentrada especialmente na região Sudeste. ${ }^{22}$

Em todo caso, corrigir as distorções na Câmara dos Deputados e torná-la mais proporcional, reduziria-se, em tese, a expressão da sobre-representação no Senado. E talvez cabesse ao Senado não ter sua representação igualitária questionada - como quer Backes -, mas ter menos atribuições do que tem. Em suma, esta última posição é a defendida por Stepan (1999), que, como já vimos, tem uma visão que prioriza o modelo majoritário de democracia. Richard Snyder e David Samuels (2004) seguem o mesmo caminho, mas recolocando a questão do ponto de vista da câmara baixa: "embora uma longa tradição federalista reconheça o valor de uma legislatura bicameral, com uma câmara alta representando o princípio igualitário do território, uma situação que requer um nível

\footnotetext{
${ }^{20}$ A fonte dos índices do Produto Interno Bruto (PIB) é do IBGE, 2005 (www.ibge.gov.br).

${ }^{21}$ Nicolau (1997) questiona esta clivagem alegando que existe contrastes de ordem populacional e socioeconômica dentro de cada região. Embora faça sentido, vamos manter a análise com esta clivagem básica nos atendo aos seus aspectos gerais, até porque as diferenças entre de um lado Norte, Nordeste e Centro-Oeste e Sudeste e Sul de outro, são grandes.

${ }^{22}$ Maurício Puls (2002) argumenta que a sub-representação histórica de São Paulo e Minas Gerais na Câmara dos Deputados nunca os incomodou e ajudou a manter a unidade territorial do país. A principal razão é que estes dois estados exerceram o poder de fato - na história republicana - por meio da Presidência. Dos 28 presidentes, retire-se os sete militares não eleitos. Pois dos 21 civis eleitos, São Paulo assumiu 10 vezes o cargo e Minas seis vezes. Além disso, Minas já teve 10 vice-presidentes do país. É um campo de interpretação interessante e que mereceria ser mais explorado, mas foge ao alcance deste trabalho.
} 
significativo de desproporcionalidade, há um consenso de que ao menos uma câmara deve conceder o mesmo peso do voto aos cidadãos. Portanto, não existe qualquer justificação normativa para a desproporcionalidade na câmara baixa." (Snyder e Samuels, 2004:132).

O problema estaria situado em um Senado excessivamente poderoso e/ou em uma Câmara dos Deputados que duplica a sobre-representação do Senado? Será mesmo que se a Câmara fosse mais proporcional isto teria algum efeito de controle democrático sobre as ações federativas do Senado? Estas perguntas nos remetem a uma reflexão sobre se estas distorções têm conseqüências para as decisões tomadas. É como diz Backes: "no Congresso de hoje, que decisões poderiam ser diferentes caso o modelo adotado fosse mais próximo da proporcionalidade?” (Backes, 1998:14). A próxima tabela apresenta um quadro geral, ao somar os representantes nas duas câmaras.

Tabela 2.3 - Desproporcionalidade de representação legislativa federal brasileira por região.

\begin{tabular}{|l|c|c|c|c|c|c|}
\cline { 3 - 7 } \multicolumn{2}{c|}{} & \multicolumn{2}{c|}{ Câmara dos Deputados (CD) } & $\begin{array}{c}\text { Senado Fede- } \\
\text { ral (SF) }\end{array}$ & \multicolumn{2}{c|}{ CD + SF } \\
\hline Região & $\begin{array}{r}\text { \% da popu- } \\
\text { lação por } \\
\text { região } \\
\mathbf{( 2 0 0 5 )}\end{array}$ & $\begin{array}{c}\text { Situação atu- } \\
\text { al (1) }\end{array}$ & $\begin{array}{c}\text { Com propor- } \\
\text { cionalidade (2) }\end{array}$ & Igualdade (I) & $\mathbf{1}+$ I & $\mathbf{2}+1$ \\
\hline Norte & 7,98 & 65 & 40 & 21 & 86 & 61 \\
\hline Nordeste & 27,70 & 151 & 144 & 27 & 178 & 171 \\
\hline Centro- & 7,07 & 41 & 35 & 12 & 53 & 47 \\
\hline Oeste & 42,60 & 179 & 218 & 12 & 191 & 230 \\
\hline Sudeste & 14,64 & 77 & 76 & 9 & 86 & 85 \\
\hline Sul & & & & & & \\
\hline
\end{tabular}

Fontes: Elaboração própria a partir do site do Instituto Brasileiro de Geografia e Estatística (www.ibge.br) e Soares e Lourenço, 2004.

Procuramos adicionar o número de representantes das regiões nas duas casas legislativas. Existe uma correção de desproporção apenas na Câmara, pois parte-se do princípio de que o Senado deve ser equivalente em sua representação. Desta forma, vemos nas duas últimas colunas que o grau 
de desproporção é mais favorável à região Norte e mais desfavorável à região Sudeste, o que só reforça o que já havia sido constatado quando analisamos a tabela 2.1.

A pergunta acima formulada sobre a possibilidade de maior controle da Câmara - por causa da correção de sua proporcionalidade - sobre o Senado também fica no campo das hipóteses mas, de qualquer maneira, tem de lidar com o fato de que as minorias das regiões menos populosas podem vetar a passagem de legislação sem grande dificuldade no Senado. Para entendermos um pouco melhor como isso pode acontecer temos de levar em conta como opera o bicameralismo brasileiro com relação ao processo legislativo e a conseqüente extensão dos poderes de cada casa, especialmente com relação às emendas constitucionais, teoricamente, o aspecto mais sensível do ponto de vista federativo.

\section{Simetria e vetos através das emendas constitucionais}

Existe um consenso na literatura de que o bicameralismo brasileiro é forte, além da incongruência, os poderes das casas são equivalentes (ou simétricos). De forma sintética para os fins a que nos propomos, cabe diferenciar três tipos de atividades entre as duas câmaras no processo legislativo brasileiro. 1) Das sessões conjuntas; 2) dos projetos de lei e 3) das propostas de emendas constitucionais.

As sessões conjuntas acontecem em duas situações, primeiro numa análise de um veto presidencial a um projeto de lei aprovado pelas duas casas do Congresso, e segundo na votação de leis orçamentárias propostas pelo Executivo. ${ }^{23}$ Em boa parte dos países bicamerais, em situações como estas as duas câmaras tornam-se uma só. Mas o caso brasileiro é diferente, pois cada câmara conserva sua identidade na hora de votar (Backes, 1998; Llanos, 2002). Ou seja, contam-se os votos separadamente em cada casa. E se uma delas tiver menos votos que o necessário, a matéria em questão é rejeitada. Em tese, portanto, é mais fácil tanto uma aprovação como uma rejeição por parte do Senado, pois ele tem menos membros que a Câmara.

Com relação aos projetos de lei de origem legislativa, eles podem ser iniciados nas duas casas. Uma casa introduz, delibera e aprova um projeto. Em seguida envia para a outra casa, que o aprova totalmente e o projeto é promulgado. Ou então, se propor alterações, o projeto volta à casa iniciadora. E ainda se reprovar o projeto por inteiro ele é arquivado. Após a volta do projeto da segunda casa para a primeira casa, esta pode aprovar o projeto sem incluir as alterações propostas pela segunda casa. Ou

\footnotetext{
${ }^{23}$ De acordo com o parágrafo terceiro do artigo 57 da Constituição. Vale lembrar que este método também era usado para a votação de medidas provisórias até setembro de 200. Com a promulgação da emenda constitucional 32, a tramitação das medidas provisórias deixou de ter lugar em Sessão Conjunta do Congresso Nacional. A tramitação das medidas provisórias passou a utilizar um rito próprio, um misto de tramitação seqüencial e conjunta.
} 
seja, existe uma vantagem da casa iniciadora, embora ela corra o risco do projeto ser rejeitado por inteiro pela segunda casa, o que daria por encerrado a chance de aprovação do projeto. Assim, embora a casa iniciadora conserve uma vantagem, a segunda casa tem poder total de veto, o que lhe dá um poder de barganha considerável.

Este mesmo processo de ida e vinda entre uma câmara e outra (chamado de navette ou shuttle, pela literatura internacional) acontece quando o projeto vem fora do Congresso, ou seja, do Executivo, do Superior Tribunal Federal, dos Tribunais Superiores ou da iniciativa popular. Mas aqui há uma assimetria entre as duas casas. Pois todos estes projetos de lei são iniciados obrigatoriamente na Câmara dos Deputados. Isso significa que a palavra final sobre os projetos cabe a esta casa. Embora, como já vimos, o Senado retém o poder de rejeição integral para si, o que daria por arquivado um dado projeto. Dizendo de outra forma, o Senado não decide sobre o conteúdo final de um projeto aprovado. Mas pode rejeitá-lo.

Mas a mais provável simetria entre as duas casas e, por conseguinte, um maior poder para o Senado, acontece quando a discussão é em nível de mudança da Constituição. ${ }^{24}$ Podem propor emendas ao texto constitucional a Câmara dos Deputados - com um pedido de no mínimo 1/3, 171 membros - o Senado Federal - também por 1/3, 27 membros -, o Executivo e mais da metade das Assembléias Estaduais. Como veremos no próximo capítulo, tem sido o Executivo e depois a Câmara e o Senado os proponentes das várias alterações desde a promulgação da atual Constituição de 1988.

A entrada de uma Proposta de Emenda Constitucional (PEC) pode ocorrer nas duas casas. Se para a votação de um projeto de lei e demais votações é necessária a aprovação por maioria absoluta de votos em um turno em cada casa - 257 na Câmara e 41 no Senado -, a proposta é votada nas duas casas em dois turnos, sendo preciso que $60 \%$ dos integrantes de cada casa a aprove. Mais exatamente, 308 deputados e 49 senadores. ${ }^{25}$ E se em qualquer destas votações a proposta não alcançar o índice mínimo, ela é rejeitada, não cabendo recurso da outra casa. Portanto, cada uma destas quatro rodadas é decisiva e é preciso que se atinja a maioria qualificada. Além disto não há limite para o número de vezes que a emenda pode ser apreciada por cada casa.

\footnotetext{
${ }^{24}$ É partindo desta simetria legislativa e considerando a, em tese, maior substância das questões tratadas, que priorizamos a análise dos vetos a seguir pela maioria qualificada exigida numa emenda constitucional. As situações de aprovacão de maioria absoluta $(50,01 \%)$, presentes em votações ordinárias não serão abordadas.

${ }^{25}$ Para além das votações nominais, a PEC antes tramita em comissões especialmente criadas para analisá-las, seguindo as regras do Regimento Interno de cada casa. Assim, na Câmara há a Comissão de Constituição e Justiça e Cidadania (CCJC) e a Comissão Especial. E no Senado há apenas a CCJC. No capítulo quatro, as funções e os efeitos destas comissões serão vistas em detalhes.
} 
Para evitar que tal quorum seja atingido, entretanto, é preciso o oposto, isto é, que $40,01 \%$ dos votos sejam contrários a uma emenda. Em um Congresso marcado por índices elevados de desproporcionalidade, faz-se oportuno verificar numericamente como estas situações poderiam ocorrer.

Tabela 2.4 - Situações possíveis de veto na Câmara dos Deputados para propostas de emendas à Constituição com a representação atual.

\begin{tabular}{|l|c|c|c|c|}
\hline Região & Representantes & \% do total & $\begin{array}{r}\text { Número para } \\
\text { o veto de 206 }\end{array}$ & $\begin{array}{c}\text { do ve- } \\
\text { to }\end{array}$ \\
\hline Norte & 65 & 12,67 & -141 & 31,55 \\
\hline Nordeste & 151 & 29,43 & -55 & 73,30 \\
\hline $\begin{array}{l}\text { Centro- } \\
\text { Oeste }\end{array}$ & 41 & 7,99 & -165 & 19,90 \\
\hline Sudeste & 179 & 34,89 & -27 & 86,89 \\
\hline Sul & 77 & 15,01 & -129 & 37,38 \\
\hline São Paulo & 70 & 13,69 & -136 & 33,98 \\
\hline
\end{tabular}

Fontes: Elaboração própria.

Vemos na tabela acima que as duas regiões que mais se aproximam de uma situação de veto são a Sudeste $(86,89 \%)$ e a Nordeste $(73,3 \%)$, justamente as duas mais populosas - a primeira com $42,6 \%$ e a segunda com $27,7 \%$. Devido ao problema da má alocação dos representantes em seus estados, somando-se a região Nordeste (com uma desproporção de apenas 1,36\%), com a região Norte $(4,88 \%)$ já seria atingido o veto com uma margem de 4,85\%. Já com relação à região Centro-Oeste $(1,17 \%)$, o veto não seria conseguido, ficando em 6,8\% aquém do necessário. Obviamente, somando as três regiões, o veto na Câmara dos Deputados seria conseguido com uma folga de $24,75 \%$.

Uma união das duas regiões mais desenvolvidas do país, com 74,9\% do PIB, 57,24\% da população e um índice de sub-representação de 7,6\% na Sudeste e sobre-representação de 0,2\% na Sul, atingiria o veto com um índice favorável de $24,27 \%$. Ora, praticamente o mesmo das três regiões menos desenvolvidas e sobre-representadas do país. Numa hipotética situação de aliança, tanto das regiões mais pobres, como das mais ricas seria possível bloquear uma emenda constitucional. Isso mostra que, a despeito da desproporção favorável às regiões Norte, Nordeste e Centro-Oeste, as regiões Su- 
deste e Sul têm meios de afirmar seus interesses, caso eles possam eventualmente existir. Por fim, colocamos São Paulo na tabela, devido ao seu alto índice de sub-representação $(8,19 \%)$. O estado sozinho representa pouco mais de um terço do necessário para vetar uma emenda à Constituição.

Tabela 2.5 - Situações possíveis de veto na Câmara dos Deputados para propostas de emendas à Constituição com a representação proporcional corrigida.

\begin{tabular}{|l|c|c|c|c|}
\hline Região & Representantes & \% do total & $\begin{array}{c}\text { Número para } \\
\text { o veto de 206 }\end{array}$ & \% do veto \\
\hline Norte & 40 & 7,80 & -166 & 19,42 \\
\hline Nordeste & 144 & 28,07 & -62 & 69,90 \\
\hline $\begin{array}{l}\text { Centro- } \\
\text { Oeste }\end{array}$ & 35 & 6,82 & -171 & 16,99 \\
\hline Sudeste & 218 & 42,50 & +12 & 105,83 \\
\hline Sul & 76 & 14,81 & -130 & 36,89 \\
\hline São Paulo & 112 & 21,83 & -94 & 54,37 \\
\hline
\end{tabular}

Fontes: Elaboração própria.

Pois continuemos com São Paulo no início da interpretação desta tabela. Com a proporcionalidade exata, o estado mais rico $(33,4 \%$ do PIB) e mais populoso $(21,96 \%)$ teria pouco mais da metade do necessário para o veto $(54,37 \%)$ e representaria dentro de sua região, também praticamente metade dos votos, com 51,37\%.

Já o concerto da região Nordeste com a Norte, representaria 10,68\% menos que o necessário para um veto. Somando estas duas regiões com a Centro-Oeste, teríamos um índice de 6,31\% além do necessário para o veto. De outro lado, a região Sudeste poderia vetar sozinha, com uma margem de $5,83 \%$. Em resumo, o mais significativo desta tabela 2.5 , que mostra a correção da representação proporcional, é, de um lado, que a soma das três regiões mais sub-desenvolvidas continuaria permitindo um situação de veto. E de outro, que a região Sudeste poderia vetar sozinha, com metade dos votos de um único estado, uma emenda à Constituição na Câmara. 
Tabela 2.6 - Situações possíveis de veto no Senado Federal para propostas de emendas à Constituição.

\begin{tabular}{|l|c|c|c|c|}
\hline Região & Representantes & \% do total & $\begin{array}{c}\text { Número para } \\
\text { o veto de 33 }\end{array}$ & \% do veto \\
\hline Norte & 21 & 25,92 & -12 & 63,64 \\
\hline Nordeste & 27 & 33,34 & -6 & 81,82 \\
\hline $\begin{array}{l}\text { Centro- } \\
\text { Oeste }\end{array}$ & 12 & 14,81 & -21 & 36,36 \\
\hline Sudeste & 12 & 14,81 & -21 & 36,36 \\
\hline Sul & 9 & 11,12 & -24 & 27,27 \\
\hline
\end{tabular}

Fontes: Elaboração própria.

Chegamos agora ao Senado. Aqui a possibilidade de veto é muito maior, primeiro por causa do tipo de representação - que é igualitária - e segundo por causa da distribuição irregular do número de estados por regiões. Para termos uma idéia mais precisa do quadro representativo em termos comparativos, as regiões Norte, Nordeste e Centro-Oeste somam 60 senadores $(74,07 \%)$ e as regiões Sudeste e Sul têm 21 (25,93\%). As três primeiras regiões possuem 42,76\% da população nacional e as duas últimas regiões, 57,24\%. Temos visto que de acordo com a Constituição, é preciso a aprovação de $3 / 5$ (60\%) dos senadores para aprovar uma PEC. Portanto, é necessário o voto de 49 senadores. Em termos aritméticos nem seria preciso a concordância das três regiões para impedir a aprovação de uma emenda. Pois se tomarmos por região, bastaria os 21 votos da região Norte (com 7 estados), mais 12 da região Nordeste (4 estados) - digamos que os senadores dos estados menos $\operatorname{populosos}^{26}$ - para termos o número de veto mínimo de 33 senadores. Neste caso, é possível que representantes de apenas $13,96 \%$ da população brasileira decidam sobre uma matéria constitucional. Mas este número pode ser ainda menor, caso escolhamos os 11 estados menos populosos, que não por coincidência estão nas três regiões mais sobre-representadas. ${ }^{27}$ Neste caso, o número seria de 10,79\% em condições de vetar uma mudança constitucional, em oposição a representantes de $89,21 \%$ da população brasileira.

\footnotetext{
${ }^{26}$ Os estados menos populosos do Nordeste são o Sergipe (1.967.791), Rio Grande do Norte (3.003.087), Piauí (3.006.885) e Alagoas (3.015.912). (IBGE, 2007).

${ }^{27}$ Estes estados são: Região Norte: Acre, Amapá, Rondônia, Roraima e Tocantins. Região Nordeste: Sergipe, Rio Grande do Norte e Piauí. Região Centro-Oeste: Distrito Federal, Mato Grosso e Mato Grosso do Sul.
} 
Mesmo com números tão expressivos a favor de uma minoria no Senado, o poder das regiões Norte, Nordeste e Centro-Oeste para aprovar uma proposta de alteração da Constituição não ocorre na Câmara dos Deputados, pois com seus votos somados, teríamos 257, ou seja, ficaria faltando $51(16,56 \%)$ para conseguir chegar a 308 votos. Quer dizer, poderiam aprovar na casa federativa, mas não na casa popular. Já as regiões Sudeste e Sul não poderiam reagir no Senado para evitar a aprovação de uma PEC de interesse das outras regiões, pois seus votos somados perfazem apenas 21, 12 a menos que o necessário para vetar.

As regiões Sudeste e Sul têm mais dificuldades de alterarem o status quo a seu favor, porque em minoria nas duas casas do Congresso não teriam como aprovar uma emenda apenas com a soma dos votos de suas regiões. E se observarmos novamente a tabela 2.5 , veremos que nem com a representação proporcional corrigida isto seria possível, pois a soma dos votos das duas regiões dá o total de 294, 14 menos que o mínimo para alcançar os dois terços.

A possível chance de manifestação de vontade destas duas regiões poderia ser efetiva na Câmara dos Deputados, no caso de bloquear o interesse das três regiões menos desenvolvidas em alterar o status quo. Como vimos na tabela 2.4, a soma dos votos dos deputados do Sudeste e do Sul conseguiria vetar uma emenda constitucional. Com isso, sabendo que uma dada proposta foi aprovada pelas três regiões ou mesmo pelos 11 estados menos populosos, estes deputados vetariam a proposta com a soma dos seus votos. E nem precisariam antecipar-se ao Senado, pois necessariamente teriam duas oportunidades de voto na Câmara dos Deputados.

Com isso, a questão de uma federação demos constraining - como criticada por Stepan (1999) - deve ser relativizada. Pois, se de um lado, os estados menos desenvolvidos podem aprovar a mudança constitucional no Senado, não podem fazê-lo por si mesmos na Câmara. O poder real destas três regiões é para vetar o interesse das outras duas regiões em mudar a Constituição, em ambas as casas. Por outro lado, se as regiões Sudeste e Sul não podem por si mesmas mudar a Constituição, podem vetar uma alteração que contrarie seus interesses em ao menos uma das casas, a Câmara dos Deputados.

Desta maneira, o princípio segundo o qual a proporcionalidade da câmara baixa compensa ou equilibra a representação paritária da câmara alta, mantém-se na democracia federativa brasileira, mesmo com os índices de sobre-representação existentes na Câmara dos Deputados. Pois, se as regiões Norte, Nordeste e Centro-Oeste tem o poder de juntas aprovar e vetar no Senado, as regiões 
Sudeste e Sul podem vetar na Câmara dos Deputados. Há mais poder para as regiões Norte, Nordeste e Centro-Oeste, mas não de maneira suficiente para mudarem por si mesmas o status quo a seu favor. Já as outras duas regiões, se não podem manifestar um poder proativo, podem fazê-lo do ponto de vista reativo.

\section{Conclusões}

Iniciamos este capítulo com uma breve exposição sobre alguns aspectos dos efeitos legislativos dos sistemas bicamerais e a relevância, por vezes não considerada, da câmara alta, bem como suas características, em termos de expressão dos seus poderes e os critérios para sua representação.

A partir desta exposição, abordamos a relação entre as duas casas legislativas brasileiras, pela breve análise do processo legislativo mostrando que - ao contrário do que parte dos analistas postula - o bicameralismo brasileiro não é perfeitamente simétrico e incongruente, mas sim moderadamente assimétrico e incongruente. A diferença a favor da Câmara dos Deputados é que por ela inicia-se uma ampla proposta de mudança legislativa vinda de fora, especialmente do poder Executivo, que é quem protagoniza a própria produção legislativa no país. Se entra primeiro nela, caso o Senado não vete, é ela quem tem a palavra final, podendo, inclusive, desconsiderar o que eventualmente possa ter sido alterado pelo Senado, inclusive em questões de âmbito federativo.

E finalmente, a questão principal tratada neste capítulo foi a característica e os possíveis efeitos da igualdade de representação no Senado - com alta sobre-representação a favor das regiões menos populosas - em consonância com a proporcionalidade distorcida da Câmara dos Deputados que prejudica a região Sudeste e, em especial, seu estado mais populoso.

Tomamos como ponto privilegiado de análise comparativa os números mínimos para aprovação e veto de uma emenda à Constituição, do ponto de vista de uma clivagem entre as três regiões menos ricas e mais sobre-representadas: Norte, Nordeste e Centro-Oeste e as duas regiões mais ricas e sub-representadas, Sudeste e Sul. Com isso, procuramos responder se 1) o Senado pode vetar qualquer mudança, agindo contra o interesse da maioria e 2) caso a Câmara tivesse sua proporcionalidade corrigida, poderia evitar o poder de veto do Senado.

No primeiro caso, vimos que o Senado, de fato, tem poder de vetar qualquer alteração constitucional, alocada nas três regiões acima citadas. Mas, de outra parte, observamos algo que é pouco notado, de que o eventual interesse destas regiões de mudar uma legislação de nível constitucional, 
só pode ocorrer se houver concordância da Câmara. E nesta casa, estas regiões não tem maioria suficiente, mesmo que já estejam sobre-representadas. Já as regiões Sudeste e Sul não formam maioria em nenhuma das duas casas, mas podem, se for o caso, evitar uma mudança que lhes possa prejudicar agindo na Câmara. Assim sendo, é preciso relativizar este poder destas três regiões no Senado, porque se elas podem de fato vetar, não tem o poder unilateral de aprovar algo que seja de seu interesse mais próximo ou em contraposição aos das duas outras regiões.

No segundo caso, vimos que a somatória dos votos das três regiões mais sub-desenvolvidas continuaria permitindo um situação de veto no Senado. Mas o dado novo - e não surpreendente - é que a região Sudeste poderia vetar sozinha - com metade dos votos de um único estado, o de São Paulo -, uma emenda à Constituição na Câmara. Ou seja, se o poder desta região seria reposto em sua dimensão real em relação às outras, por outro acentuaria ou tornaria mais explícito em termos representativos o alto grau de desigualdade existente no interior da federação brasileira. Se por um lado defende-se a correção da representação em termos mais proporcionais, pois isso seria mais justo do ponto de vista democrático, por outro acentuaria as desigualdades no arranjo federativo do país.

Em síntese, há duas questões de fundo relacionadas: Primeiro, é aceitável que as minorias tenham uma sobre-representação, mas não a ponto de impedir a maioria de tomar decisões. Vimos acima que tal fato - ao menos em parte - ocorre, pois para as três regiões mais sobre-representadas aprovarem mudanças constitucionais precisam da concordância das outras duas regiões em situação oposta na Câmara. E em segundo, uma proporcionalidade numericamente corrigida poderia levar a uma tirania dos estados mais populosos em relação aos menos populosos. Vimos pelos resultados da tabela 2.5 que a região mais populosa do país poderia vetar sozinha uma mudança na Constituição. De certa forma, esta última sentença reforça o argumento daqueles que entendem que a desproporção de representação na Câmara é menos problemática do que se imagina e estaria de encontro com uma solução mais consociativa e integradora para o perfil desigual em termos populacionais e econômicos da democracia federativa brasileira.

No fundo, este debate sobre o poder de aprovação e/ou veto das regiões sobre ou subrepresentadas reflete a questão do equilíbrio que deve haver em um sistema representativo, não existindo nem a situação de tirania da maioria e nem de veto da minoria. Wanderley Guilherme dos Santos (1987) foi pioneiro em explorar este aspecto da democracia brasileira: "não é suficiente que um sistema seja representativo, no sentido de distribuir poder parlamentar tão aproximadamente igual ao poder eleitoral dos partidos - garantindo aí a representação das diversas correntes de opini- 
ão. É necessário, ademais, que as minorias parlamentarmente representadas não sejam esmagadas pela maioria, nem por outro lado, tenham condições de impedir a maioria de governar. $\mathrm{O}$ equilíbrio entre o direito da minoria à representação e audiência parlamentares e o direito da maioria ao governo não-despótico é a regra de ouro (...) para a operação de qualquer sistema representativo, que será tanto mais justo quando mais equilibrado for." (Santos, 1987:77). ${ }^{28}$

Nesse sentido, veremos nos próximos dois capítulos como os embates políticos em torno de uma base democrática sob um formato federativo e - portanto - consociativo - foram concretamente vividos no governo de Fernando Henrique Cardoso, o primeiro em tempos de democracia a lograr uma sucessão, manter-se oito anos no poder e transmitir o cargo de forma democrática a um candidato de um partido de oposição. Pois se este governo é significativo em termos democráticos, também é do ponto de vista de sua agenda transformadora do Estado brasileiro, com ênfase nas relações da União com os estados, ou seja, de amplo impacto federativo. E o caminho institucional trilhado por este governo foi exatamente as várias propostas de emenda à Constituição, o que dá prosseguimento aos temas que temos tratado até aqui, com a ênfase especial no papel do Senado no processo, como será visto no capítulo quatro, quando será abordada a questão do ajuste fiscal da década de 90.

\footnotetext{
${ }^{28}$ Chama a atenção, contudo, que em seu estudo entre 1946 e 1982, o autor só tenha considerado para análise a Câmara dos Deputados, embora tenha afirmado que o bicameralismo brasileiro - pelo menos no período de 1946-1964 - fosse forte. Santos conclui que havia equilíbrio entre o poder de aprovação das maiorias e veto das minorias, mas ao deixar de fora o Senado torna suas conclusões questionáveis, como observa Backes, 1998.
} 


\section{Capítulo 3}

\section{O governo reformista de Fernando Henrique Cardoso}

Apesar de ser o quarto mandato presidencial do país desde a volta da democracia em 1985, e de ser o segundo a chegar ao poder pelo voto direto, o governo de Fernando Henrique Cardoso é especialmente importante em comparação com os anteriores, tanto do ponto de vista políticoinstitucional, como do econômico.

Em primeiro lugar, Fernando Henrique Cardoso liderou a criação e implementação do Plano Real - ainda sob o governo anterior, de Itamar Franco (1992-1994), na condição de ministro da Fazenda -, que finalmente debelou o vigoroso processo inflacionário que o país vivia desde o início dos anos 80. E por meio do êxito deste plano de estabilização econômica, em boa medida, se elegeu presidente da República, assumindo com grande apoio político e popular, um governo que seria marcado por seu processo de reformas estruturais do Estado brasileiro.

Neste capítulo procuraremos, inicialmente, situar do ponto de vista federativo, o contexto em que surgiu este governo, desde a gênese que tornou possível a transição, os primeiros anos do novo regime democrático - marcado por uma preponderância política dos interesses dos governadores estaduais em relação ao governo federal - até as dificuldades de enfrentamento da crise econômica. O momento em que o Plano Real foi posto em prática representa uma mudança nas posições relativas de poder entre os atores, neste caso, entre os governadores de estado - daqui em diante menos poderosos - e a União, mais fortalecida.

Desta maneira, o objetivo principal deste capítulo é caracterizar a agenda do governo Fernando Henrique Cardoso e como ela esteve relacionada com as questões federativas, através das reformas via emendas constitucionais. Por meio delas, em boa medida, houve mudanças no interior do federalismo brasileiro, tal como concebido na Constituição de 1988. Pois se uma das características mais fortes do processo constituinte foi exatamente o caráter descentralizador do Estado federativo, o governo de Fernando Henrique Cardoso procurou reorganizá-lo à luz das novas necessidades de estabilização da economia, do novo momento político que lhe era favorável e do enfrentamento de uma ampla pauta de demandas sociais, presentes no próprio texto constitucional. 
Como a ênfase neste trabalho é o aspecto federativo, faremos uma diferenciação entre os tipos de emendas constitucionais aprovadas, ou seja, suas áreas temáticas, separando-as em institucionais, econômicas e federativas. Cada uma delas será justificada em sua especificidade e importância, no sentido de abordarmos com mais detalhes as reformas constitucionais de perfil federativo.

E dentro deste tema, abordaremos também dois aspectos-chave da agenda reformista deste governo e que afetou diretamente a federação: 1) o aspecto fiscal, no qual reformas caminharam no sentido de alterar o equilíbrio entre as unidades federativas, a favor da União e 2) o caráter de indução e condicionamento das políticas sociais que restringiu a autonomia decisória dos estados e municípios.

\section{Antecedentes, o novo contexto e o Plano Real}

Durante os anos 80 o Brasil viveu dois processos paralelos, um político e outro econômico. De um lado, uma transição política longa, iniciada em 1982 com a volta da eleição dos governadores de Estado, que culminaria com a eleição indireta de um civil e o fim do domínio militar em 1985. Depois a promulgação da Constituição de 1988 e a eleição de um presidente em 1989 teria, em termos institucionais, levado o processo a bom termo e devolvido o país na trilha da democracia. De outro, uma crise econômica grave, iniciada com o crescimento da dívida externa, o aumento do déficit público e uma inflação de dois dígitos mensais, que ficava maior a cada novo governo e novos fracassos de seguidos planos econômicos.

Do ponto de vista do federalismo, estes primeiros anos de redemocratização foram marcados pelo ressurgimento da força política dos governadores em relação ao Executivo federal. A origem desta situação tem sua gênese na própria crise do regime militar que, em linhas gerais, foi marcada por uma grande preponderância do governo federal em relação aos governos subnacionais.

Assim, durante a ditadura militar o federalismo brasileiro passa por três períodos distintos e complementares. De 1964 a 1974 está muito enfraquecido, por causa da enorme concentração do poder no governo federal. Em termos políticos há o fim das eleições estaduais e nacionais para o Executivo e a criação do bipartidarismo. Em termos militares, o Exército assume o controle das polícias estaduais civis e militares e as secretarias estaduais de segurança. Em em termos fiscais, ocorre uma concentração da maioria dos impostos para o governo federal, com pouca autonomia para os estados e municípios. Pela Constituição de 1967, de 14 impostos do sistema tributário nacional, 10 são definidos como de atribuição da União. Muitos impostos não são mais repassados para os esta- 
dos e municípios. E os que são, estão condicionados obrigatoriamente em áreas definidas pelo governo federal. (Sallum, Jr.,1996).

Tirando as condições para o exercício autônomo dos poderes estaduais, o governo federal orienta as políticas regionais, quer por seus próprios organismos, quer pela moldagem das administrações dos estados. Mesmo assim, a manutenção de alguns procedimentos democráticos para selecionar periodicamente os quadros políticos, ainda que de forma distorcida pelo bipartidarismo 'artificial' e a ausência de disputa para os cargos executivos em nível nacional e estadual, abriu a possibilidade de uma mudança deste padrão.

Desta maneira, uma segunda fase do federalismo sob o regime militar ocorre depois do crescimento eleitoral da oposição nas eleições legislativas de 1974. Com o aumento expressivo no número de deputados e senadores do Movimento Democrático Brasileiro (MDB) e a ascensão ao poder presidencial do General Ernesto Geisel a ditadura passa a viver um segundo momento, em que a palavra de ordem é uma liberalização do regime. Do ponto de vista das relações federais, os centros de poder estaduais ocupam uma posição mais importante no processo de abertura do regime.

Isto culmina no terceiro momento, com a volta do multipartidarismo em 1979 e das eleições para governador em 1982, que sinaliza o começo do fim do regime militar, especialmente depois do desempenho eleitoral da oposição, que conquista os governos dos estados de São Paulo, Minas Gerais e Rio de Janeiro, os três principais do país. ${ }^{29}$ Somado a este novo quadro político partilhado entre generais ditadores e governadores eleitos, o Brasil passa por uma crise econômica grave, com alta da inflação e da dívida externa. Há também o contexto internacional, que é favorável à queda dos regimes autoritários nos países em desenvolvimento. Este conjunto de fatores torna a ditadura mais frágil e permite o processo de transição que levou o Brasil de volta à democracia em 1985.

Este contexto sinaliza que as instituições federativas emergem de um período de latência. Gibson (2004) situa o momento de forma genérica para os países federativos que passaram por processos de mudança de regime ou institucional, e o Brasil compartilha deste cenário. Para este autor, “as instituições federais geralmente são ativadas por mudanças exógenas do sistema como um todo,

\footnotetext{
${ }^{29}$ Em um texto em que compara as transições políticas do Brasil e da Espanha, Juan Linz (1983) foi, creio, o primeiro a designar a situação brasileira com o neologismo de 'diarquia'. Com isso queria dizer que com a eleição dos governadores em 1982 o regime autoritário brasileiro vivia com duas esferas diferentes de legitimidade. A primeira, imposta, ditatorial, sem respaldo eletivo. E a segunda, subnacional, pluralizada com situação e grupos opositores concorrendo ao poder de forma eletiva, democrática, mesmo no interior de um regime nacionalmente autoritário.
} 
via mudança de regime político, mudança nas leis eleitorais ou outros 'choques'externos (...) Uma vez adotadas, as instituições federais com frequiência têm vida própria, acelerando um processo de descentralização além do que os formuladores políticos intencionaram, ou mudando arenas e recursos de competição política e mobilização." (Gibson, 2004:9). Claro que há nuances entre um país e outro mas, para ficarmos no caso brasileiro, a argumentação de Gibson está basicamente correta.

Como a estrutura do Estado brasileiro é federativa, podemos considerar - assim como nas demais federações -, que os seus dois principais veto players em relação ao governo federal são os governadores de estado e os senadores. Os primeiros, por serem os principais mandatários de um ente subnacional, eleitos democraticamente e com poderes políticos e legais próprios. Já os segundos, são os representantes dos entes subnacionais na arena de decisão legislativa federal, contando com uma casa exclusiva para atuarem, assim como uma série de atribuições e poderes, alguns dos quais específicos de sua função, como no caso brasileiro.

Neste período de mudança de regime é oportuno destacar o papel exercido pelos governadores. ${ }^{30}$ Assim, seguindo o argumento de Fernando Abrucio (1998), "a crise do regime autoritário abriu portas para que novos atores ascendessem no cenário político, entre os quais os mais importantes foram os governadores e os líderes políticos regionais. Tal fato se explica primeiro pela redemocratização ter começado, de fato, por uma eleição estadual e não por uma disputa no plano nacional, como foi típico nas 'novas democracias'que se constituíam à época. (...) Sobretudo com a vitória das oposições em 1982, o sistema político se reconstruía ‘de baixo para cima'”. (Abrucio, 1998:22).

Este mesmo autor denominou o modelo autoritário acima descrito de 'unionista', por seu óbvio caráter centralizador e autoritário. A partir de sua crise e inviabilidade, o novo contexto da transição forjou dois fenômenos duplos, que ele chama de 'federalismo estadualista' e 'ultrapresidencialismo estadual'.

O federalismo de viés estadualista pode ser explicado como aquele no qual os estados se fortaleceram sem no entanto estabelecerem coalizões hegemônicas de poder no plano nacional para reconstruir o Estado e o sistema político. E este fortalecimento, além dos fatores eleitorais e de enfraquecimento do poder presidencial que se instaura no poder através de uma eleição indireta, é alimentado pelas características do jogo político no interior dos estados. O fenômeno é nomeado por

\footnotetext{
${ }^{30}$ Já com relação aos senadores, eles serão abordados de forma empírica no próximo capítulo.
} 
Abrucio, de 'ultrapresidencialismo estadual', por apresentar três características principais: (1) o controle do Executivo do processo decisório em toda a sua extensão; (2) os outros Poderes não constituírem checks and balances sobre o Executivo e (3) o governador ser o principal centro das decisões do governo, não havendo um grau de dispersão de poder como no nível federal na relação entre presidente e ministros.

No 'federalismo estadualista', a estrutura de divisão interna do Estado brasileiro favoreceu os governadores e a lógica política estadual. Desta maneira, os governadores conseguiram acomodar seus interesses em torno do novo federalismo, montado na Constituição de 1988. Para Abrucio (1998), depois da criação deste 'federalismo estadualista', os governadores só atuaram em conjunto de forma defensiva, para garantir os ganhos obtidos. Entre as principais características deste momento político do país, temos:

- A lógica das disputas eleitorais é 'estadualizada', pois as eleições para os governos dos estados acontecem junto com as eleições legislativas estaduais e federais, nos anos de 1982, 1986 e 1990.

- Os governadores não atuavam de forma coordenada e cooperativa. Ao contrário, prevalecia uma conduta individualista e não-cooperativa.

- Os governadores não estabeleciam relações de cooperação com o governo federal.

- Os presidentes têm dificuldades em formar coalizões para governar. Um sistema político em formação, com vários partidos e baixa institucionalização no plano nacional, em contrapartida com presença forte em alguns estados.

- Crise econômica grave, com inflação alta, déficit público elevado e juros altos da dívida externa.

- Aumento dos repasses de recursos fiscais na Constituinte em 13\%.

- Os bancos estaduais também se tornam fonte de 'recursos protegidos'para os governadores.

- Influência dos governadores no Congresso Nacional a qualquer mudança federativa que lhes é desfavorável, criando dificuldades para o governo federal.

Este momento mais favorável aos governadores de estado no interior da federação brasileira, não colaborou quer para o enfrentamento da crise econômica quer para a própria institucionalização do novo regime democrático. No primeiro aspecto, porque os governos subnacionais comportaramse de forma prejudicial em relação aos interesses nacionais, com políticas próprias e desvinculadas 
dos objetivos nacionais, tornando mais difícil o combate aos problemas econômicos. No segundo aspecto, porque teriam tornado mais difícil a implementação de uma agenda nacional do governo federal, por causa de sua influência junto aos parlamentares federais.

Para Brasilio Sallum Jr. (2003) a conclusão deste processo paralelo representaria, este sim, o fim da transição iniciada em 1982. Por um lado é compreensível o ponto em que o autor quer chegar: uma espécie de conjunção político-econômica que deu rosto a um novo período histórico. Por outro lado, do ponto de vista estritamente político - como usualmente tratado pela Ciência Política - a transição é identificada como iniciada em 1982 e completada em dois momentos decisivos e complementares, a Constituição de 1988 e a eleição presidencial de 1989.

Como estamos tratando da contextualização de um processo político-econômico, faz sentido adotarmos esta linha de abordagem que chamaria de estruturalista e não apenas políticainstitucional. Assim, a eleição de Fernando Henrique Cardoso representou um momento de inflexão do país, tanto do ponto de vista político, como do econômico.

Podemos apontar que os parâmetros acima listados sobre o 'federalismo estadualista' começam a desvanecer. Se não, vejamos:

- A eleição presidencial de 1994 foi a primeira casada do novo período democrático. Quer dizer, foi realizada ao mesmo tempo que as eleições para os governos estaduais, e as de deputado e senador em nível federal e deputados em nível estadual. Esta mudança do calendário eleitoral - que permanece até hoje - não é um fator secundário, pois influenciou a lógica da disputa eleitoral. Seus candidatos em nível estadual e nacional e as coligações e alianças partidárias conseqüentes, tiveram uma transferência de uma lógica de disputa regional para uma nacional, para o principal cargo em disputa. Diríamos que o eixo político-eleitoral do jogo de poder no interior da federação redirecionou-se para o centro.

- Os governadores seguem atuando de forma não cooperativa entre si, aumentando o grau de competitividade, principalmente na área fiscal.

- Os governadores passam a, gradativamente, estabelecer vínculos de colaboração com o governo federal, em algumas áreas chave de política social, como a educação e saúde. 
- O presidente é eleito com o apoio de uma coalizão ampla em termos de divisão de poder ministerial e conseqüente apoio partidário no Congresso, formada inicialmente pelo PSDB, PFL, PMDB e PTB.

- A crise econômica é enfrentada com um ajuste fiscal e o Plano Real.

- Os estados mantém os níveis de transferência fiscal estabelecidos na Constituição de 1988, mas o FSE desvincula $20 \%$ do que seria repassado a eles, para uso da União.

- Os bancos estaduais sofrem intervenção, com sua posterior privatização, transformação em agência de fomento ou extinção. Isso, sem dúvida, tira um recurso importante dos governos estaduais.

- O Executivo federal, além da montagem de uma coalizão grande e disciplinada, passa a exercer - como nenhum outro governo pós-1988 -, os poderes legislativos garantidos pela Constituição. Podemos dizer que tanto a formação da coalizão, como o exercício pleno dos poderes veio em decorrência da orientação para o centro da eleição. Pois, "ao contrário dos outros pleitos ocorridos na redemocratização, o presidente eleito teve significativa influência na formação da Câmara dos Deputados e nas governadorias. Isso aumentou a possibilidade de o presidente formar um bloco político para implementar reformas e até reconstruir um novo pacto político hegemônico.” (Abrucio, 1998:220).

É importante destacar - ainda que de forma breve - que o substrato que permitiu a própria concepção e implementação do Plano Real e seu posterior êxito sob um novo governo é a constatação de que o país não poderia viver indefinidamente sob inflação e que era preciso debelá-la. Sallum Jr. (2003) argumenta que foi criado um consenso no país naquele momento de que não era mais possível viver indefinidamente sob os efeitos da inflação, pois poderia comprometer o próprio futuro do país.

O desvanecimento destes parâmetros que tornou forte o 'federalismo estadualista' nos primeiros anos da redemocratização, mostra que além deste consenso em torno de uma idéia central, houve algumas razões de ordem política e institucional. Para além da já citada mudança do calendário eleitoral, a aprovação do Fundo Social de Emergência - ainda sob o governo de Itamar Franco, em fevereiro de 1994 -, deu início a um processo de ajuste fiscal que impulsionou o Plano Real, 
posto em funcionamento alguns meses depois. ${ }^{31}$ E o êxito inicial do plano permitiu a eleição de Fernando Henrique Cardoso no mesmo ano.

Desta maneira, o argumento de Abrucio (1998) sobre as feições de um federalismo estadualista e com características predatórias não explica de forma satisfatória este novo contexto a partir do êxito do Plano Real. Ou não da mesma maneira, pois como veremos no próximo capítulo, o pendor predatório poderia, agora, funcionar a favor dos interesses da União.

O Plano Real representou uma conjuntura crítica, uma mudança fulcral na posição relativa dos atores políticos e sociais em relação aos instrumentos de poder e às preferências. Para Kugelmas e Sola (2000), este fato "muda expressivamente a correlação de forças entre governo federal e estados, graças a um conjunto de fatores. A vitória sobre a ameaça hiperinflacionária e a eleição do novo presidente fez renascer com redobrada legitimidade a clássica tradição brasileira de presidência forte, esmaecida durante a crise que derrubou o presidente Collor. A linha mestra do novo governo era a de consolidar o processo de estabilização, o que significava o combate aos desequilíbrios fiscais e, mais a longo prazo, um ambicioso projeto de superação do velho modelo nacionaldesenvolvimentista, sintetizado na expressão 'superação da era Vargas'. Assim, reforma profunda do aparato estatal e integração competitiva na ordem econômica internacional globalizada passam a ser as palavras de ordem." (Kugelmas e Sola, 2000:71). E como observam ainda Couto e Abrucio (2003), coube à liderança do presidente Fernando Henrique Cardoso um papel central, ao montar e manter por praticamente dois mandatos uma coalizão partidária capaz de realizar alterações na estrutura anterior, segundo os objetivos perseguidos por ele e seus aliados.

Esta interpretação nos leva a afirmar que - antes de mais nada - houve uma mudança no caráter das composições políticas. Antes deste governo, as coalizões formadas mostraram-se muito instáveis quando aos seus apoios, objetivos e permanência. Vemos, por exemplo, que no governo de Fernando Collor de Mello (1990-1992), a dificuldade inicial já partia do próprio presidente, pertencente a um partido pequeno - o Partido da Reconstrução Nacional (PRN) -, formado apenas para que ele concorresse à Presidência e com representação inexpressiva no Congresso. Nos dois anos e seis meses em que permaneceu no poder ocorreram três montagens de coalizões, sendo que até o

\footnotetext{
${ }^{31}$ A aprovação do FSE foi a primeira das seis emendas aprovadas na revisão constitucional de 1994. Elas aconteceram de forma diferente das emendas pelo processo normal, isto é, exigiram um processo mais simples de votação e aprovação, por maioria absoluta dos membros do Congresso Nacional, em sessão unicameral. Como veremos no próximo capítulo, este trâmite mais simples tornou a aprovação da emenda mais rápida, facilitando os interesses do governo. Além disso, uma instituição-chave do ponto de vista federativo ficou alijada, o Senado Federal que, teoricamente, poderia criar alguma dificuldade para o governo federal.
} 
PRN deixou a coalizão, em abril de 1992, quando vicejava a pleno curso as denúncias de corrupção em seu governo.

Itamar Franco (1992-1994) veio a seguir e de saída já tinha uma dificuldade, pois ele não estava filiado a nenhum partido. E muito embora tenha contado com o apoio de partidos importantes, como o PSDB, o PMDB e o PFL tinha uma posição relativa a eles enfraquecida, pelo próprio caráter tampão de seu mandato. Ainda assim, é verdade, foi em seu governo que foi criado e implementado o Plano Real, que com seus frutos exitosos já no segundo semestre de 1994, permitiu a vitória de Fernando Henrique Cardoso.

Sob este governo a coalizão montada principalmente entre o PSDB e o PFL e secundada pelo PMDB, PTB e PPB passou por quatro fases em oito anos. No primeiro mandato a sustentação parlamentar era próxima a 75\% das cadeiras na Câmara e no Senado, um índice mais que suficiente para aprovar a série de emendas constitucionais, cujo objetivo era permitir que as reformas fossem realizadas.

Pois a Constituição de 1988 era excessivamente descentralizada - com parcelas expressivas de transferências fiscais para os estados e municípios e poucos instrumentos de arrecadação fiscal por parte da União - e reguladora com relação à atividade econômica, com restrições ao capital estrangeiro, ampliação das áreas de atuação de empresas estatais, além dos servidores públicos e trabalhadores privados terem aumentado seus direitos trabalhistas e previdênciários.

Portanto, se ela assegurou a "permanência [da] velha articulação entre o Estado e o mercado no momento mesmo em que o processo de transnacionalização e a ideologia liberal estavam para ganhar uma dimensão mundial em função do colapso do socialismo de Estado" (Sallum Jr, 2003:39), era preciso redirecioná-la para que o próprio plano de estabilização da economia tivesse continuidade segura e o Estado brasileiro pudesse ser reconfigurado.

Nesse sentido, o governo - especialmente no primeiro mandato - caracterizou-se pela adoção de duas agendas principais: 1) a estabilização monetária e 2) as reformas constitucionais. Uma inevitavelmente conectada com a outra, embora ambas contenham medidas que lhes são próprias. $\mathrm{Na}$ primeira agenda, podemos citar as privatizações de algumas empresas estatais, uma reforma do sistema financeiro e os acordos sobre as dívidas dos estados. Na segunda agenda, medidas de cará- 
ter mais substantivo, reformas tais como a da previdência, a administrativa, a tributária, a trabalhista entre outras. $^{32}$

A estabilização monetária será tratada no próximo capítulo, do ponto de vista do ajuste fiscal. De momento, apenas uma introdução, linhas acima, para contextualizar o surgimento deste governo. Ela está presente por sua relação com os temas relativos à segunda agenda, as reformas implementadas por meio de alteração constitucional. Mas não em um sentido geral, mas direcionada para a temática federativa, o aspecto central deste trabalho. Afinal é uma conseqüência óbvia a relevância deste ângulo de abordagem, pois se o Estado brasileiro tem uma estrutura federativa, em tese, quase todas as transformações realizadas em seu interior tem impacto sobre os entes que o constituem.

\section{Emendar para governar}

A partir de 1988, os presidentes talvez não enfrentassem tantas dificuldades de governo, caso não precisassem alterar a Constituição com freqüência. As próprias características do texto induziam, ao menos idealmente, os governos a montar e manter coalizões não de maiorias absolutas $(50 \%+1)$, mas de maiorias qualificadas $(60 \%)$. Pois só assim poderiam realizar mudanças.

Isso porque a Constituição de 1988 é muito extensa, com seus 250 artigos e mais 94 no capítulo sobre as Disposições Constitucionais Transitórias. ${ }^{33}$ Em termos de mudança em seu texto isso representou a aprovação (até dezembro de 2006) de 53 emendas no seu texto original. Isso em apenas 18 anos de funcionamento. ${ }^{34}$ Uma das possíveis razões que explica este vigor de mudança é o caráter detalhista do texto, que abrange aspectos não tradicionais em constituições, como questões de políticas públicas e redução da desigualdade social. Esta excessiva constitucionalização da política pública pode ser um dos resultados da agenda do novo regime democrático e a insatisfação com os padrões observados na formulação de políticas nos governos militares.

O excesso de artigos e seu alcance de difícil realização prática teria sido um dos fatores a explicar um processo de alteração que buscaria reordenar o texto constitucional para capacitar o Estado

\footnotetext{
${ }^{32}$ Em parte destas últimas, o governo enfrentou mais dificuldades devido à maior controvérsia das questões, com a imposição de perdas a interesses concentrados, gerando benefícios difusos. O exemplo maior é o das tentativas de reforma tributária, que avançou pouco em seu conjunto.

${ }^{33}$ Quando foi promulgada continha 245 artigos e mais 70 nos Atos das Disposições Constitucionais Transitórias. É uma das maiores do mundo, comparável às da Índia e da África do Sul, outros dois países federativos. (Souza, 2005).

${ }^{34}$ Não estou incluindo as seis emendas constitucionais de revisão, que foram as aprovadas dentro de um cronograma que previa esta revisão desde a promulgação da Constituição em 1988. De qualquer forma, se somarmos todas as emendas, chegamos ao número de 59.
} 
a tornar concreto o conteúdo proposto. Se a Constituição na maior parte dos países é mudada apenas em situações excepcionais, com tudo o mais sendo deliberado e resolvido no âmbito da lei ordinária, no Brasil viveríamos um processo de constitucionalização regular, como se estivéssemos em processo constante de revisão e modificação do texto. O que pode ser considerado como positivo neste quadro é que a inclusão de tantas demandas não-constitucionais, de fundo principalmente social, colocou em definitivo estas questões na pauta de prioridades nacionais, fazendo com que o Estado brasileiro tivesse de dar uma moldura estrutural e jurídica para o atendimento destas demandas.

Embora estejamos nos estendendo neste tema, é importante abordá-lo, pois como se verá adiante, está dentro de uma das principais características do governo Fernando Henrique Cardoso, as reformas do Estado. Seguindo por esta via, Couto (2001) distingüe três âmbitos distintos e complementares sobre as decisões dos agentes estatais. Pois nem tudo o que é decidido tem a mesma importância e o mesmo alcance, seja pela maior complexidade do processo formal de tomada de decisões, seja pela própria maneira como o Estado atinge os resultados de suas ações. Assim sendo, "as decisões constitucionais dão forma à organização política propriamente dita, à politéia - ou para utilizar o termo inglês de uso mais corrente, à polity. É a estrutura constitucional do Estado, a polity, que define as condições do jogo político propriamente dito (a politics). A Constituição compreende o conjunto das regras do jogo, mas não define em princípio os resultados do jogo, as decisões políticas tomadas (as policies). Estas decorrem do desfecho de conflitos, negociações e acordos travados entre os participantes dos diversos âmbitos da polity." (Couto, 2001:34).

Temos, portanto, três níveis diferentes da atividade estatal. A polity relacionada à estrutura (regras do jogo), a politics à operação, funcionamento (articulações e ações entre os grupos políticos) e as policies, ao que foi conseguido a partir das regras e das ações, os resultados. Ou para dizer de outro modo, em princípio estamos diante de uma gradação, em termos do que condiciona o quê: as regras constitucionais (polity) condicionam o jogo político (politic), que condiciona o conteúdo das políticas (policy).

Nesta diferenciação teórica o que é relevante para o caso brasileiro, segundo Couto, é que esta sequiência de condicionamento está alterada. Isso porque, como dito acima, a Constituição do país está impregnada de conteúdos de policies e não apenas de polity. Estaria aí uma das principais razões para a mudança regular do texto constitucional, pois o conteúdo de policy - que deveria ser o resultado passa a ser uma estrutura da ação do Estado. O que demandaria sua alteração no texto constitucional para transformá-lo em policy e, desta forma, torná-lo mais factível de ser realizado. Assim, o fato das 
mudanças terem de ser feitas em âmbito constitucional torna necessário que se construa maiorias legislativas amplas, afim de superar o engessamento prévio a que foi submetida a agenda governamental pelo constituinte, algo, em tese, mais difícil no contexto institucional de uma federação e de um sistema de governo presidencialista bicameral e multipartidário.

Ainda de acordo com Couto e Rogério Arantes (2002), os governos brasileiros pós-1988, especialmente durante os dos dois governos de Fernando Henrique Cardoso, se viram obrigados a "desenvolver boa parte de sua produção normativa no plano constitucional, isto é, por meio de modificações, acréscimos e/ou supressões de dispositivos localizados na própria Constituição. Tomar decisões e implementar políticas governamentais são atividades que, no Brasil pós-1988, não lograram adquirir apenas uma rotina infra-constitucional. Pelo contrário, boa parte dessas atividades teve lugar no nível superior da hierarquia legislativa, ou seja, na própria Constituição.” (Couto e Arantes, 2002:75). Para usar os termos dos autores, o que era estrutural (a polity) se transformou em conjuntural (policy) e o que era conjuntural (policy) adquiriu aspectos estruturais (polity) no caso brasileiro. ${ }^{35}$

Este aspecto de mudança freqüente da Constituição brasileira chama também a atenção por não se enquadrar nas características comuns às constituições de países federativos. Lijphart (2003) argumenta que uma das peculiaridades que distinguem uma federação de uma não-federação é o caráter rígido do texto constitucional. No qual são necessárias supermaiorias para alterar o texto. De acordo com o autor, um dos motivadores deste aspecto seria a proteção dos interesses e garantias dos entes federativos em relação aos interesses nacionais. Assim, em algumas federações, além da maioria qualificada (de $60 \%$ ou 67\%) ser exigida no Parlamento nacional, é necessária também a aprovação por maioria de mais da metade e por vezes de até três quartos das assembléias legislativas estaduais! $!^{36} \mathrm{Ou}$ seja, o texto constitucional é protegido contra mudanças de ocasião, preservando os princípios norteadores do sistema político e valores da própria sociedade (ou seja, a polity).

Tal nível de enrijecimento talvez seja exagerado, mas também o pode ser considerado o oposto, como o caso brasileiro (policies com status constitucional). Nesse sentido, para os fins deste trabalho a intenção a seguir será a diferenciação entre os temas das emendas constitucionais, para demarcar o lugar das de cunho federativo, uma marca do governo Fernando Henrique Cardoso. E para o próximo capítulo, realizaremos uma avaliação mais detida no processo de ajuste fiscal - especialmente as

\footnotetext{
${ }^{35}$ Em um trabalho mais recente, os dois autores desenvolvem uma metodologia de análise constitucional (MAC) com o intuito de examinar a Constituição por inteiro classificando o que é de fato norma constitucional (polity) ou conteúdos de políticas públicas (policies). Detalhes em Couto e Arantes, 2006.

${ }^{36}$ Este é o caso dos Estados Unidos.
} 
de alteração constitucional -, tendo como foco analítico o papel do Senado e os eventuais poderes de restrição a maiorias (demos), conforme exposto por Stepan (1999).

Como vimos acima, tanto Collor, como Itamar estiveram à frente de governos politicamente instáveis e pouco capazes de construir amplas maiorias que lhes permitissem atingir eventuais objetivos de reformas. Mesmo assim no caso de Itamar é preciso lembrar que foi em seu governo que se planejou e colocou em prática um programa de ajuste fiscal - com a aprovação do Fundo Social de Emergência - e o Plano Real, que reordenaram radicalmente o quadro da economia brasileira. Assim, apesar do governo Fernando Henrique Cardoso ter o mérito de manter a estabilização da moeda e por em prática uma ambiciosa agenda de reformas, as bases foram criadas e implementadas no governo Itamar. Desta maneira, apesar dos problemas anteriores citados, este presidente tem a seu favor o fato de ter escolhido Fernando Henrique Cardoso para Ministro da Fazenda. E este, através da sua capacidade de liderança em meio a um contexto de consenso em torno do combate à crise inflacionária, tornou possível a gestação e efetivação de um plano de boa qualidade técnica, que com seu êxito inicial contribuiu de forma decisiva para a sua eleição à Presidência no mesmo ano de 1994.

Pertence a uma certa corrente da literatura comparativa sobre as políticas de reforma a visão de que as instituições políticas brasileiras geram paralisia decisória e inércia política. E com isso, “espera-se que as reformas só venham a ocorrer após negociações prolongadas envolvendo o presidente e o Congresso e com um alto custo social.” (Marcus André Melo, 2005:851). Por um lado, tais dificuldades estiveram presentes nestes dois governos, mas por outro seria da própria natureza substantiva de uma reforma constitucional que houvesse mais deliberações e custos envolvidos. O que, de certa forma, complicaria o quadro é que nem todas as reformas pretendidas precisariam de fato ser realizadas, caso o próprio conteúdo da Constituição fosse mais enxuto ou mais de polity do que de policy. Apenas o governo de Fernando Henrique Cardoso conseguiu um percentual de maioria qualificada, que lhe permitiu alterar o texto constitucional de forma regular mesmo com os eventuais obstáculos acima observados.

É certo que estas alterações aconteceram em consonância com uma desobstrução da pauta de negociações entre os dois poderes, pela delegação ao Executivo de capacidade legislativa mediante a reedição de medidas provisórias. (Figueiredo e Limongi, 1999; Amorim Neto e Tafner, 2002). Passando ao presidente a atribuição de decidir de forma autônoma sobre parte da produção legal, o Congresso abriu caminho para os trabalhos referentes às deliberações de caráter constitucional. As- 
sim, as duas agendas operaram de forma articulada: uma, constituinte e consociativa - a das reformas constitucionais - relativas ao remodelamento estrutural do Estado. E outra, delegativa e majoritária - a das medidas provisórias reeditadas - voltada prioritariamente para os aspectos relativos à agenda estabilizadora da economia.

\section{Reformas federativas por via constitucional}

Abrucio e Costa (1998) elencam cinco aspectos principais em que a estrutura federativa dificulta o processo de reforma estatal, levado a cabo pelo governo de Fernando Henrique Cardoso.

O primeiro deles estaria relacionado com as pressões estaduais. A razão é que os parlamentares responderiam às suas lealdades estaduais em tensão permanente com suas lealdades partidárias. Além disso, como grande parte da estrutura do Executivo federal é descentralizada, qualquer mudança teria uma reação dos parlamentares que participam do processo de nomeação aos cargos públicos federais, sobretudo no alto escalão.

O segundo é que o próprio governo federal sendo um dos entes federativos, deve ser reformado para adquirir uma nova função em suas relações intergovernamentais. Tanto para assumir funções de coordenação, como também para atuar como indutor de correções das desigualdades entre as regiões.

O terceiro é que esta desigualdade torna necessária uma atuação conjunta do governo federal com os governos subnacionais, pois em contrário será criado um modelo de desenvolvimento socioeconômico concentrador nas regiões mais ricas, aprofundando ainda mais o problema.

O quarto está voltado ao problema dos gastos públicos, especialmente os dos governos subnacionais, que afetam a gestão da macroeconomia, especialmente no que diz respeito ao déficit público proveniente de eventuais descontroles das contas.

E o quinto é aquele relativo à implementação de políticas sociais. Como elas foram constitucionalmente descentralizadas (especialmente saúde e educação), se os governos subnacionais não forem capazes de geri-las, parte significativa do projeto de reforma do Estado perderá legimidade social. 
Embora todos os cinco aspectos estejam relacionados, abordaremos mais adiante neste capítulo aqueles relativos à questão do ajuste fiscal e das políticas sociais.

Se, como argumentamos, o governo Fernando Henrique Cardoso foi o primeiro desde a redemocratização a conseguir apoio político para realizar reformas com este alcance, também é possível afirmar que ele só o levou adiante porque tinha um projeto de Estado em mente. Em relação aos governos anteriores, tal projeto ou não estava suficientemente amadurecido, envoltos em conjunturas político-econômicas mais adversas, ou não fazia parte de suas agendas de governo.

Como observa Arretche (2007), “já estavam presentes [na Constituição de 1988], dispositivos que conferiam à União autoridade privativa para normatizar sobre as políticas a serem executadas por estados e municípios, bem como sobre a arrecadação dos impostos estaduais e municipais." (Arretche, 2007:31). Assim, desde o princípio já estava embutida a decisão dos constituintes de homogeneizar a prestação de uma série de políticas descentralizadas, com o objetivo de diminuir as disparidades entre as regiões, os estados e os municípios. Com isso, o governo Fernando Henrique Cardoso toma a decisão de colocar em prática estes dispositivos, começando, com isso, a centralizar o processo decisório sobre as competências dos governos subnacionais.

Nesse sentido foram aprovadas 35 emendas entre as propostas em seus oito anos de duração, com uma média superior a quatro por ano. Como veremos adiante, deste total o poder Executivo teve iniciativa de propor 17 (11 no primeiro mandato e 6 no segundo), o que representa quase a metade, $48,57 \%$.

Com relação ao número total de 53 emendas promulgadas até o fim de 2006, as aprovadas por este governo representam 66,04\%. As razões que explicam estes números expressivos por parte deste governo em particular está, por um lado, relacionado com os aspectos acima mencionados de reformar as instâncias do Estado brasileiro. Promoveu, desta forma, alterações importantes em áreas diversas como saúde, educação, saneamento básico, habitação, previdência, sistema financeiro, programas de desestatização de empresas, regulamentação fiscal e tributária, agências regulatórias, reforma eleitoral e outras. É certo que nem todas foram plenamente bem-sucedidas como o governo pretendia, mas o mecanismo das emendas constitucionais tornou-se regular em boa parte destas reformas, com a intenção de permitir a realização concreta dos conteúdos sociais previstos na Constituição (policies) e reestruturar o Estado brasileiro (polity). 
Se, como afirmam Abrucio e Costa (1998), subjacente ao conteúdo destas reformas estaria a própria reconstrução do federalismo brasileiro, tal qual concebido em 1988, o que lhe seria específico? Ou seja, quais destas 35 emendas teriam como tema e alcance principal - ou mais facilmente visualizável -, a questão federativa?

Para responder a esta questão, em primeiro lugar segui o caminho destes dois autores, de apontar a relevância particular do redesenho da federação nas emendas que procuraram reformar o Estado brasileiro. Em seguida dividi as emendas constitucionais em três áreas temáticas principais: 1) sobre questões institucionais; 2) sobre aspectos econômicos e 3) sobre impactos sobre os entes federativos.

Assim, temos:

1) Institucional (sobre instituições políticas, regras decisórias, cidadania);

2) Econômica (monopólios públicos, privatizações, normas macroeconômicas) e

3) Federativa (relações intergovernamentais, regras decisórias com alcance sobre os entes federativos, áreas do controle fiscal e de políticas sociais com efeitos distributivos sobre os entes federativos). ${ }^{37}$

Para melhor compreensão, vamos citar brevemente um exemplo de emenda de cada um destes temas. Para ficarmos no governo que pretendemos analisar de forma detida, o de Fernando Henrique Cardoso, uma emenda de tema institucional foi a de número 23. De autoria do poder Executivo e promulgada em 2 de setembro de 1999, no início do segundo mandato, ela criou o Ministério de Estado da Defesa. O impacto institucional vincula-se às regras de organização e hierarquia dos militares das três forças, agora subordinados a uma única pasta ministerial e dirigida, preferencialmente, por um civil.

Com relação a uma emenda constitucional de tema econômico, citamos a de número 9, promulgada em 9 de novembro de 1995 e de autoria do poder Executivo. Seu conteúdo foi dos mais polêmicos à época, ao tratar da flexibilização do monopólio da exploração das fontes de petróleo no país, abrindo o mercado para as empresas estrangeiras.

\footnotetext{
${ }^{37}$ Tomei como base o trabalho de Melo (2005), no qual os sub-temas incluídos dentro da área federativa estão separados. Como todos têm impacto sobre os entes federativos juntei-os aqui em uma única área temática, chamada de ‘federativa'. Ressalto que também não abordo a desagregação das emendas constitucionais nos termos do método de Couto e Arantes (2006), isto é, com relação ao seu status constitucional, se polity, politic ou policy. A separação que nos importa aqui é temática, no sentido de situar o tema de cada emenda, da forma como ela foi definida e sua quantidade.
} 
Já uma emenda de tema federativo é a da reforma administrativa, com impacto sobre os gastos e contratações com servidores nas três esferas de governo no país. Foi a emenda de número 19, aprovada no primeiro mandato em 4 de junho de 1998, e de iniciativa do poder Executivo.

Está claro que as emendas não são excludentes quanto aos seus temas e o alcance de uma em relação a outra. Como ressalva Melo, "estas categorias não são mutuamente exclusivas, dentre outras coisas, porque muitas emendas são longas peças legislativas 'multidimensionais', mas ajudam a destacar a importância do federalismo.” (Melo, 2005:883).

A próxima tabela separa todas as 53 emendas constitucionais de 1992 a 2006 pelas áreas temáticas.

Tabela 3.1 - Emendas constitucionais aprovadas (1992-2006) por área temática

\begin{tabular}{|l|c|c|c|c|}
\hline \multirow{2}{*}{ GOVERNOS } & \multicolumn{3}{|c|}{ ÁREA TEMÁTICA } & \multirow{2}{*}{ TOTAL } \\
\cline { 2 - 5 } & INSTITUCIONAL & ECONÔMICA & FEDERATIVA & 2 \\
\hline Collor & 1 & 0 & 1 & 2 \\
\hline Itamar & 1 & 0 & 9 & 16 \\
\hline FHC I & 3 & 4 & 8 & 19 \\
\hline FHC II & 8 & 3 & 7 & 53 \\
\hline Lula I & 5 & $26(49,0 \%)$ & 14 \\
\hline Total & $18(34,0 \%)$ & $9(17,0 \%)$ & & 26 \\
\hline
\end{tabular}

Fontes: Elaboração própria a partir dos sites da Câmara dos Deputados (www.camara.gov.br) e do Senado Federal (www.senado.gov.br), da Constituição da República Federativa do Brasil (2007a) e de Melo (2005).

Por meio dos dados acima constatamos que mesmo nos governos Collor e Itamar, com poucas emendas constitucionais, metade em cada um deles foi de tema federativo. ${ }^{38}$ Já nos dois mandatos de Fernando Henrique Cardoso as emendas federativas representaram praticamente a metade. Das 35, 17 são de tal tema $(48,57 \%)$. Se as desagregarmos por mandato, observamos que no primeiro representa-

\footnotetext{
${ }^{38}$ A do governo Collor foi a emenda constitucional número 1 (31 de março de 1992). Ela limitou os salários dos deputados estaduais a $75 \%$ dos vencimentos dos deputados federais. E dos vereadores a $75 \%$ dos vencimentos dos deputados estaduais. Seria uma emenda relacionada à regra decisória com impacto sobre os entes subnacionais, no caso o poder legislativo. Já a emenda de tema federativo do governo Itamar foi a de número 3 (17 de março de 1993), relativa a aspectos do ajuste fiscal, tal como as aposentadorias e pensões dos servidores federais e o imposto sobre movimentação financeira (IPMF).
} 
ram pouco mais da metade do total $(56,20 \%)$ e no segundo um percentual pouco abaixo da metdade $(42,10 \%)$. Vemos também que no primeiro governo de Luiz Inácio Lula da Silva o ímpeto de emendas de tema federativo manteve-se no mesmo patamar, em $50 \%$. O que sugere que o processo iniciado pelo governo anterior teve prosseguimento.

Mas não na iniciativa de cada poder proponente. Se separarmos as emendas em geral por quem as iniciou, verificaremos que o governo Fernando Henrique Cardoso é o único que tem a liderança do poder Executivo. Acompanhe na tabela abaixo:

Tabela 3.2 - Emendas à Constituição (1992-2006) aprovadas por cada governo segundo sua autoria.

\begin{tabular}{|l|c|c|c|c|c|c|}
\hline Governo & Collor & Itamar & FHC I & FHC II & Lula & Total \\
\hline Executivo & 0 & 0 & 11 & 6 & 3 & 20 \\
\hline Câmara & 1 & 2 & 4 & 5 & 6 & 18 \\
\hline Senado & 1 & 0 & 1 & 8 & 5 & 15 \\
\hline Total & 2 & 2 & 16 & 19 & 14 & 53 \\
\hline
\end{tabular}

Fontes: Elaboração própria a partir dos sites da Câmara dos Deputados (www.camara.gov.br) e do Senado Federal (www.senado.gov.br).

Na tabela 3.2 vemos que das 53 emendas aprovadas, 20 tiveram origem no poder Executivo (37,73\%), 18 (33,96\%) na Câmara e 15 no Senado (28,31\%). Mas 17 das 20 iniciadas pelo Executivo partiram do governo Fernando Henrique Cardoso, isto é, $85 \%$ do total. Em termos práticos o poder Executivo foi decisivo apenas neste governo.

Pelos números acima fica claro que o governo Fernando Henrique Cardoso foi muito mais ativo do que os outros, tanto em quantidade, quanto em que poder teve mais iniciativa em mudar a Constituição. Alguém pode indagar se esta quantidade e iniciativa representa também conteúdo. Quer dizer, se estas emendas foram aquelas mais ambiciosas no sentido de reformar as estruturas do Estado, inclusive no aspecto federativo.

Ao analisarmos as emendas aprovadas de iniciativa do poder Executivo nos dois mandatos deste governo, verificamos que as principais no que diz respeito às reformas foram levadas adiante no 
primeiro mandato. Refiro-me à emenda 8 (que quebra o monopólio das telecomunicações), à já citada emenda 9 (relativa à quebra do monopólio à exploração do petróleo e seus derivados), as emendas 10 e 17 (sobre a prorrogação do Fundo Social de Emergência, com o nome de Fundo de Estabilização Fiscal), a emenda 14 (sobre o Fundo de Manutenção e Desenvolvimento do Ensino Fundamental e de Valorização do Magistério [Fundef]), a emenda 19 (sobre os princípios e normas da administração pública) e a emenda 20 (sobre a reforma da previdência social). Já no segundo o ímpeto diminuiu, com destaque para as emendas 23 (ministério da Defesa) e 27 (sobre a desvinvulação de receitas da União [DRU], prosseguimento das emendas 10 e 17).

Além disso, este governo também logrou aprovar emendas importantes por meio de parlamentares pertencentes à sua coalizão como, por exemplo, a emenda 16 (que instituiu a reeleição para a disputa dos cargos dos Executivos nos três níveis da federação), de autoria do deputado Mendonça Filho (PFL-PE) e a emenda 29 (que assegura os recursos para o financiamento das ações e dos serviços públicos de saúde, o Sistema Único de Saúde [SUS]), de autoria do deputado Carlos Mosconi (PSDBMG). ${ }^{39}$ Este aspecto, aliás, tornou-se mais presente no segundo mandato, quando a maior parte das emendas tiveram origem (formal ao menos) nas duas casas do Legislativo (Oito emendas pelo Senado e cinco pela Câmara). ${ }^{40}$ Portanto, este deve ser considerado como um aspecto a mais para constatarmos a eficácia do governo na busca de seus objetivos em reformar as estruturas do Estado e também em desconstitucionalizar questões de políticas sociais.

Seguindo por esse caminho, é oportuno verificarmos o que os números informam sobre as emendas constitucionais originárias da Câmara e do Senado. Se partirmos do princípio óbvio de que o Executivo é governo, no Legislativo é possível que existam emendas originadas por parlamentares vinculados aos partidos de oposição. Em tese, isso poderia nos dizer que os interesses do governo foram contrariados, ou que ele não conduziu a agenda, digamos assim, em determinado tema. Por outro lado, como as emendas podem tramitar de um governo para outro, não seria estranho se o governo de turno viesse a apoiá-la, mesmo partindo de um partido oposicionista de um outro mandato. Primeiro,

\footnotetext{
${ }^{39} \mathrm{O}$ caso da aprovação desta emenda é um pouco diferente, pois embora ela tenha sido aprovada no segundo mandato de Fernando Henrique Cardoso por um deputado do seu partido, originalmente o tema de vinculação de recursos para a saúde é de autoria do deputado federal Eduardo Jorge (PT-SP), da oposição. Esta proposta iniciou tramitação em 1993, como a PEC 169/1993. Dois anos depois, Mosconi apresentou outra PEC - 82/1995 -, incorporando parte do conteúdo da primeira. Portanto, foi uma emenda incorporada pelo governo a partir de uma proposta inicial da oposição, mesmo que de um governo anterior (de Itamar Franco), pois o PT permaneceu na oposição com o novo governo. Para detalhes, ver o relatório da Associação Paulista de Medicina, de 2001.

${ }^{40}$ Como vimos no capítulo anterior, o artigo 60 da Constituição, em seu parágrafo primeiro, determina que as emendas vindas das casas do Legislativo precisam da assinatura de um terço de seus respectivos membros. Isso representa, 171 membros na Câmara dos Deputados e 27 no Senado. Talvez isso explique, em parte, a maior quantidade de emendas aprovadas com origem no Senado, no segundo mandato.
} 
porque neste novo governo, este partido pode ter se incorporado à coalizão. Segundo, porque o tema em si também pode ser de seu interesse, já que ele pode ter incorporado à sua agenda uma proposta anteriormente pertencente à oposição. De qualquer forma, a tabela 3.3 nos mostra a que grupo político pertence a proposta das emendas de autoria das casas do Legislativo.

Tabela 3.3 - Emendas constitucionais aprovadas pela Câmara e Senado segundo a posição política. $^{41}$

\begin{tabular}{|l|c|c|c|c|c|c|c|c|c|c|c|c|}
\hline Governos & \multicolumn{2}{|c|}{ Collor } & \multicolumn{2}{c|}{ Itamar } & \multicolumn{2}{c|}{ FHC I } & \multicolumn{2}{c|}{ FHC II } & \multicolumn{2}{c|}{ Lula I } & \multicolumn{2}{c|}{ Total } \\
\hline Autoria/Posição & C & O & C & O & C & O & C & O & C & O & C & O \\
\hline Câmara & 0 & 1 & 2 & 0 & 3 & 1 & 4 & 1 & 6 & 0 & 15 & 3 \\
\hline Senado & 0 & 1 & 0 & 0 & 1 & 0 & 8 & 0 & 2 & 3 & 11 & 4 \\
\hline Total & 0 & 2 & 2 & 0 & 4 & 1 & 12 & 1 & 7 & 4 & 25 & 8 \\
\hline
\end{tabular}

Fontes: Elaboração própria a partir dos sites da Câmara dos Deputados (www.camara.gov.br), do Senado Federal (www.senado.gov.br) e de Figueiredo, 2006.

Os números da tabela mostram mais uma vez o contraste com o governo de Fernando Henrique Cardoso. Em oito anos de seus dois mandatos a coalizão iniciou e aprovou 16 emendas à Constituição e a oposição apenas duas. Em termos percentuais, isso significa 88,89\% para a coalizão e 11,11\% para a oposição. Uma demonstração de que a coalizão, liderada pelo Executivo, foi bemsucedida em aprovar os projetos de seu interesse.

No primeiro mandato, na Câmara dos Deputados, a coalizão aprovou três e a oposição uma emenda. As emendas aprovadas com apoio do governo foram a de número 13 (acabou com o monopólio da União sobre resseguros) - de teor econômico -, a emenda 15 (criou obstáculos para a criação de novos municípios) - esta com impacto sobre os entes da federação - e a já citada emenda 16 (sobre a reeleição para presidente, governadores e prefeitos). Já pelo Senado foi a provada a 12 (sobre a criação do 'imposto do cheque', a Contribuição Provisória sobre Movimentação Financeira [CPMF]), aqui classificada como de tema econômico, mas que, indiretamente, tem impacto federativo.

\footnotetext{
${ }^{41}$ Nesta tabela, Coalizão é "C" e Oposição é "O”. Partidos que aprovaram emendas: Governo Collor - Câmara: PSDB e Senado: PMDB. Governo Itamar - Câmara: PMDB. Governo FHC I - Câmara: PPS (oposição), PPR e PFL; Senado: PP. Governo FHC II - Câmara: PC do B (oposição), PFL e PSDB; Senado: PFL, PPB, PMDB e PSDB. Governo Lula I - Câmara: PT, PMDB, PL; Senado: PFL (oposição) e PT (coalizão).
} 
Como vimos, o número de emendas aprovadas pelo Legislativo aumentou muito no segundo mandato. De cinco, saltou para 13, sendo que cinco vieram da Câmara e oito do Senado. Não é o caso de repassar em detalhes todas as doze emendas aprovadas pela coalizão, pois o que interessa é o conteúdo de tais emendas, se elas foram tão significativas quanto aquelas aprovadas por iniciativa do poder Executivo.

A maior parte das chamadas 'emendas da reforma do Estado', foram promulgadas por iniciativa do governo ainda no primeiro mandato. Mesmo assim, o Executivo também encaminhou propostas de emendas através de seus apoiadores no Congresso, especialmente no segundo mandato. Assim, tivemos algumas destas emendas com o propósito de continuar ou aperfeiçoar as aprovadas no primeiro mandato. Foi o caso da emenda 21 (que prorrogou a CPMF), a continuidade do 'aperto' sobre os poderes municipais, com a emenda 25 (que impôs limites de gastos para as câmaras municipais) uma continuidade da emenda número 1 e da emenda número 15 -, a emenda 26 (que procurou incorporar a questão da habitação à destinação de recursos sociais), a emenda 30 (sobre o parcelamento dos precatórios judiciários, por parte de cada ente federativo, inclusive a União) - que mantém em pauta a questão tributária, a mais presente entre os temas de alteração constitucional -, a emenda 31, que vai na mesma toada, com a criação do fundo de erradicação da pobreza.

Mas quais foram as duas emendas aprovadas pela oposição? No primeiro mandato foi aprovada a emenda 11, pelo deputado Sérgio Arouca (PPS-RJ). Ela permitiu o ingresso de professores, técnicos e cientistas estrangeiros nas universidades brasileiras, além da autonomia às instituições de pesquisa científica e tecnológica. A proposta iniciou sua tramitação em junho de 1994, ainda no governo Itamar e foi aprovada dois anos depois. No segundo mandato foi aprovada a emenda 34, de autoria da deputada Jandira Feghali (PC do B-RJ). Ela tornou possível a acumulação de dois cargos no serviço público para os profissionais da saúde. Iniciou sua tramitação em janeiro de 1996 e foi promulgada em fevereiro de 2001. E estas duas emendas tratam de temas institucionais, relativos à regras de atuação de funcionários públicos de carreira, bem como órgãos a eles vinculados. Assim, mesmo que sejam emendas secundárias do ponto de vista dos temas do governo, estavam no contexto dos seus interesses e também por isso foram aprovadas.

\section{Do perfil das emendas de tema federativo}

Até aqui abordamos o caráter reformista do governo de Fernando Henrique Cardoso por meio de suas alterações constitucionais. Se, como afirmam Abrucio e Costa (1998), o federalismo esteve no centro dos temas relativos às propostas de mudança do papel do Estado e sua reestrutura- 
ção, vamos acompanhar em que medida isto ocorreu, com quais características e de que maneira. Postulamos que as duas principais frentes de reestruturação do Estado e, por extensão, da federação brasileira, ocorreram por meio da retenção de parte de tributos partilhados com os governos subnacionais e pelo condicionamento à gestão e de políticas dos governos subnacionais, por meio de políticas sociais-chave, como educação e saúde.

Já vimos na tabela 3.1 que as emendas de tema federativo foram maioria entre os anos que ocorreram mudanças na Constituição (1992-2006). Foram 26 de um total de 53, ou seja, 49\%. E foram amplamente majoritárias nos dois mandados de Fernando Henrique Cardoso e Lula, com percentuais de $48,57 \%$ e $50 \%$ do total, respectivamente. O que nos importa discriminar daqui em diante é o perfil e as diferenças entre as emendas federativas.

Assim como diferenciamos os temas das emendas constitucionais é possível e oportuno diferenciar também as emendas de tema federativo. O objetivo é tornar claro em que áreas as emendas foram mais alteradas, no sentido de delinear as características da reestruturação do federalismo no país. Separamos as emendas de tema federativo em quatro áreas: fiscal, governamental, política e social.

Por fiscal entende-se as que tratam da distribuição de recursos entre os entes; por governamental aquelas que tratam das relações administrativas e de competências entre os entes; por políti$c a$ as que tratam de aspectos institucionais com impacto específico sobre os entes estadual e/ou municipal e por social, aquelas que determinam a destinação de recursos a serem aplicados nestas áreas. Assim como observamos antes, elas não são mutuamente excludentes, mesmo porque, por princípio, pertencem todas ao mesmo tema relativo à federação.

Da mesma maneira que fizemos antes, quando separamos as emendas em três temas distintos e citamos um exemplo para cada uma - no governo de Fernando Henrique Cardoso -, segue o exemplo de uma emenda de cada área federativa, com o mesmo objetivo de tornar o mais claro possível o critério utilizado.

A emenda constitucional número 10 pode ser classificada como exemplo na área fiscal. Promulgada em 4 de março de 1996 por autoria do poder Executivo recriou o Fundo Social de Emergência (rebatizando-o como Fundo de Estabilização Fiscal), que reteve 20\% de recursos fiscais para a União, sem repassá-los aos estados e municípios. Já a emenda constitucional número 7 foi 
promulgada em 15 de agosto de 1995 por autoria do poder Executivo. Pode ser considerada como governamental, pois suprimiu a reserva de mercado para a navegação interna, liberando-a para barcos estrangeiros no interior do país, com efeitos no comércio e na gestão nos estados que possuem rios comercialmente navegáveis. Um exemplo de uma emenda relativa à área política pode ser encontrada no segundo mandato, a de número 25. De iniciativa do senador Espiridião Amin (PPBSC), foi promulgada em 14 de fevereiro de 2000. Por meio dela foram impostos limites de gastos para as câmaras municipais, ou seja, está vinculada a um tema institucional com impacto direcionado aos entes subnacionais, no caso os municípios. Por fim, uma emenda de cunho social pode ser encontrada na de número 14. Obra do poder Executivo, foi promulgada em 12 de setembro de 1996. Criou o Fundef, condicionando parte da receita dos estados e municípios para a educação fundamental.

Tabela 3.4 - Emendas constitucionais nos governos FHC de tema federativo por sua área.

\begin{tabular}{|l|c|c|c|c|c|}
\hline \multirow{2}{*}{ GOVERNO } & \multicolumn{5}{|c|}{ FEDERATIVA } \\
\cline { 2 - 6 } & POLITICA & GOVERNAMENTAL & SOCIAL & FISCAL & TOTAL \\
\hline FHC I & 1 & 3 & 2 & 3 & 9 \\
\hline FHC II & 1 & 0 & 2 & 5 & 8 \\
\hline TOTAL & 2 & 3 & 4 & 8 & 17 \\
\hline
\end{tabular}

Fontes: Elaboração própria a partir dos sites da Câmara dos Deputados (www.camara.gov.br) e do Senado Federal (www.senado.gov.br).

A tabela 3.4 nos mostra a quantidade de emendas federativas por sua área nos dois mandatos. Vemos que as de caráter fiscal são maioria (47,06\%), seguidas pelas sociais $(23,53 \%)$, governamentais $(17,65 \%)$ e políticas $(11,76 \%)$. Também chama a atenção a grande quantidade das emendas fiscais no segundo mandato, com um percentual de 62,5\%. Isso é uma amostra da relevância do processo de ajuste fiscal empreendido por este governo em seus dois mandatos. E mesmo as de caráter social também estão vinculadas ao processo de distribuição de recursos (ou seu condicionamento) para serem administrados pelos governos subnacionais, como os casos mais notórios da educação e da saúde. 
Verificamos por meio das tabelas 3.1 e 3.2 que o poder Executivo implementou sua agenda no nível constitucional, seja por autoria própria de algumas emendas, seja por aprovação de outras pelos partidos que o apoiavam no Congresso. Pelo Executivo com 17 de um total de 35 e pelas duas casas do Congresso com mais 16 através da coalizão, perfazendo 94,28\% do total. ${ }^{42}$ Pois, como nos mostra a tabela 3.5 logo a seguir, se nos limitarmos às de tema federativo, o Executivo terá sido responsável por nove de um total de $17(52,94 \%)$ e se somarmos com as aprovadas pela coalizão nas duas casas do Congresso, teremos mais 8 , o que perfaz um total de $100 \%$.

Tabela 3.5 - Emendas constitucionais aprovadas por área temática segundo sua autoria nos governos FHC.

\begin{tabular}{|l|c|c|c|c|c|c|c|}
\hline \multirow{2}{*}{ Autoria/Mandato } & \multicolumn{2}{|c|}{ INSTITUCIONAL } & \multicolumn{2}{c|}{ ECONÔMICA } & \multicolumn{2}{c|}{ FEDERATIVA } & TOTAL \\
\cline { 2 - 7 } & $1995-98$ & $1999-02$ & $1995-98$ & $1999-02$ & $1995-98$ & $1999-02$ & \\
\hline EXECUTIVO & 1 & 3 & 3 & 1 & 7 & 2 & 17 \\
\hline CÂMARA & 2 & 1 & 1 & 1 & 1 & 3 & 9 \\
\hline SENADO & 0 & 4 & 0 & 1 & 1 & 3 & 9 \\
\hline TOTAL & 3 & 8 & 4 & 3 & 9 & 8 & 35 \\
\hline
\end{tabular}

Fontes: Elaboração própria a partir dos sites da Câmara dos Deputados (www.camara.gov.br) e do Senado Federal (www.senado.gov.br).

Se vimos na tabela 3.4 que as emendas de tema federativo na área fiscal foram maioria e que o Executivo tem sido o principal protagonista das emendas em geral e também nas federativas, observemos se a tendência se mantém com relação ao poder que originou mais emendas na área fiscal e por extensão nas demais.

\footnotetext{
${ }^{42}$ Como vimos linhas acima, duas foram de iniciativa da oposição.
} 
Tabela 3.6 - Emendas constitucionais federativas aprovadas por área temática nos governos FHC segundo sua autoria.

\begin{tabular}{|l|c|c|c|c|c|c|c|c|c|}
\hline \multirow{2}{*}{ ÁREAS } & \multicolumn{2}{|c|}{ FISCAL } & \multicolumn{2}{c|}{ SOCIAL } & $\begin{array}{c}\text { GOVERNAME } \\
\text { NTAL }\end{array}$ & \multicolumn{2}{c|}{ POLÍTICA } & TOTAL \\
\hline \multirow{2}{*}{ Autoria/Mandato } & $\begin{array}{c}1995- \\
98\end{array}$ & $99-02$ & $95-98$ & $99-02$ & $95-98$ & $99-02$ & $95-98$ & $99-02$ & \\
\hline EXECUTIVO & 2 & 2 & 2 & 0 & 3 & 0 & 0 & 0 & 9 \\
\hline CÂMARA & 0 & 2 & 0 & 1 & 0 & 0 & 1 & 0 & 4 \\
\hline SENADO & 1 & 1 & 0 & 1 & 0 & 0 & 0 & 1 & 4 \\
\hline TOTAL & 3 & 5 & 2 & 2 & 3 & 0 & 1 & 1 & 17 \\
\hline
\end{tabular}

Fontes: Elaboração própria a partir dos sites da Câmara dos Deputados (www.camara.gov.br) e do Senado Federal (www.senado.gov.br).

A tabela 3.6 nos informa que o Executivo é diretamente responsável por metade das emendas na área fiscal e social nos dois mandatos. Além de ter exclusividade nas da área das relações intergovernamentais e não ter autoria nas duas de caráter político, conforme a classificação feita. Se, como argumentamos acima, as emendas da área social contém repasses condicionados de recursos fiscais, ao somarmos as duas, chegamos a 12 emendas de um total de 17 (70,59\%). Sendo que, o Executivo é autor de seis destas emendas e os partidos que o apóiam respondem pela metade restante. Dito de outra maneira, aqui também, o governo protagonizou a totalidade das emendas que vinculam-se à arrecadação, distribuição e condicionamento de recursos fiscais e políticas sociais entre os entes federativos. Isso é amostra evidente de que o Executivo é o principal responsável pela reforma fiscal em nível constitucional, tendo como aliado importante sua coalizão no Congresso. Além disso, torna claro o perfil desta reestruturação, o ajuste fiscal - tendo como corolário também a manutenção do êxito do Plano Real - e as políticas sociais, ambas com impacto na federação. Desta forma, vamos expor a partir de agora de que maneira estas duas vertentes da reforma foram realizadas em termos gerais. ${ }^{43}$

\section{Ajuste fiscal e políticas sociais}

\footnotetext{
${ }^{43}$ Já no próximo capítulo iremos explorar a principal destas vertentes - as da área fiscal - do ponto de vista de atuação de um veto player federativo, o Senado, através dos resultados das votações desta câmara das emendas constitucionais relativas ao Fundo Social de Emergência, números 1 (revisão), 10, 17 e 27.
} 
A tabela 3.6, mostra que o governo federal recorreu às emendas constitucionais em oito oportunidades para alterar o quadro fiscal do país. Isso mostra a centralidade do tema fiscal na agenda. De um ponto de vista federativo, os principais objetivos foram o de acabar (ou diminuir o quanto possível) com os mecanismos que os governos subnacionais tinham de repassar custos à União. E a partir disto criar condições para que os estados conseguissem ajustar suas contas, por meio da renegociação de suas dívidas.

Na mesma tabela vemos que o segundo tema federativo mais alterado, via emendas, foi a área social com quatro. As duas áreas na verdade são complementares no processo de reconfigurar o modelo descentralizado consagrado na Constituição de 1988, mudando as relações intergovernamentais. A estrutura federativa em si não foi alterada em termos institucionais, mas sim a maneira como os recursos foram distribuídos, tanto do ponto de vista dos tributos, como da definição das áreas de competência de cada ente na provisão de programas sociais.

E este processo de modificação do modelo fiscal tem origem ainda antes do governo de Fernando Henrique Cardoso. Podem ser datadas já nas primeiras rodadas para renegociar as dívidas dos estados, entre 1989 e 1993. Mas o padrão só vai mudar a partir de 1994, com a aprovação do Fundo Social de Emergência (FSE), que desvinculou 20\% do que seria repassado aos estados e municípios dentro das transferências constitucionais, por meio dos Fundos de Participação. Com esta primeira medida de retenção de recursos para si, a União adquiriu força também para implementar o Plano Real, que reorganizou em novas bases a economia do país, interrompendo uma inflação crônica que vinha desde o início dos anos 80.

Este instrumento dos fundos de retenção fiscal foi realizado por meio de emendas constitucionais, seguindo o principal método de atuação deste governo para alterar a estrutura do Estado brasileiro. Ao FSE seguiu-se mais três renovações, constituindo-se em um recurso importante para a manutenção de uma posição fiscal mais favorável da União em relação aos governos subnacionais. ${ }^{44}$

Ao lado dos fundos, também foi importante a renegociação das dívidas dos estados. Apesar das rodadas iniciais em anos anteriores, ela só ganha impulso e efetividade a partir de 1995, dentro do processo de ajuste fiscal necessário para a manutenção do Real. Assim, os termos das dívidas mudaram de forma radical, pois o governo impôs condições restritivas, como metas de endividamento, su-

\footnotetext{
${ }^{44} \mathrm{O}$ caminho pelo qual cada um dos fundos foi concebido, negociado e aprovado é explicado em detalhes no próximo capítulo.
} 
perávit primário, gasto com salários, arrecadação de impostos e privatização de empresas estaduais. A perda da grande maioria dos estados sobre os seus bancos - suas principais fontes de endividamento e desajuste macroeconômico -, foi a principal consequiência e mostra da perda de poder dos estados. No total, a renegociação refinanciou um montante da ordem de R \$ 132 bilhões. (Abrucio, 2005:56).

Se o governo reteve recursos para si e disciplinou o comportamento financeiro dos estados, também foi responsável pelo aumento dos impostos não divididos com os governos subnacionais. Falo aqui das chamadas contribuições sociais, responsáveis pela grande soma de arrecadação tributária do governo federal durante os anos de 1995 em diante. Também neste caso, o método utilizado pelo governo foram as emendas constitucionais, com a criação e renovação periódica da Contribuição Provisória sobre Movimentações Financeiras (CPMF). Só para ilustrar, as contribuições sociais, que em 1980, representavam 4,9\% das receitas do governo federal, saltaram para $20 \%$ no ano 2000. Esta exclusividade sobre uma gama tão vultosa de recursos foi talvez o principal instrumento do governo federal para compensar as perdas fiscais decorrentes da descentralização fiscal a partir de 1988. (Arretche, 2005:78).

Neste processo de aumento do poder tributário e, por conseqüência, político do governo federal em relação aos governos estaduais, seguiu-se a criação da Lei de Responsabilidade Fiscal (LRF), em maio de 2000, disciplinando os gastos dos entes federativos. Para Almeida (2005), "esta lei foi uma resposta específica - e centralizadora - ao desafio de coordenar o comportamento fiscal dos governos em um sistema federativo, evitando o caronismo nos níveis subnacionais. Seu objetivo foi garantir disciplina fiscal em todos os níveis de governo, mas as restrições que impôs aos estados e municípios foram significativas." (Almeida, 2005:35). Entre as principais medidas, estão os limites para as despesas com pessoal - 60\% para estados e municípios e 50\% para a União -, limites para o endividamento, a apresentação de metas fiscais anuais, a provisão das despesas correntes e uma disposição especial para os anos eleitorais, nos quais governadores e prefeitos estão proibidos de antecipar receitas tributárias por meio de empréstimos de curto prazo, reajustar salários ou contratar novos servidores no último ano de mandato.

Todo este concerto em torno da modificação do padrão de relacionamento entre os níveis de governo reflete, em parte, uma perda de entusiasmo em torno do conceito de descentralização, em meio à crise inflacionária, à redução da capacidade administrativa do governo federal e às dificuldades de gerenciamento dos recursos disponíveis por parte dos estados e municípios. 
"A convicção de que estados e municípios tendiam a pegar carona nos esforços federais de estabilização da moeda alimentou a sabedoria convencional sobre a suposta incompatibilidade entre federalismo descentralizado e austeridade fiscal." (Idem, 2005:35). Desta forma, a autonomia dos governos subnacionais para definir parte de suas despesas e aplicação de recursos deveria ser restringida. Com isso, na prática, passa a ocorrer uma recuperação do controle da União sobre a coordenação entre os níveis de governo, com uma relação mais direta com os municípios, deixando os estados à margem, com perdas de fatias importantes da provisão destes recursos para os municípios. Desta maneira, o chamado comportamento predatório, tal qual identificado por Abrucio (1998), é alterado a favor da União, que passa, a predar os interesses e os poderes dos estados.

A perda da força da idéia da descentralização enquanto movedora de um padrão das relações intergovernamentais no federalismo brasileiro também sofreu modificação no que diz respeito aos programas sociais. A definição de competência, principalmente em educação e saúde, não foi alterada a partir do estabelecido na Constituição de 1988, mas este novo momento representou uma outra maneira desta competência ser exercida, com a criação de regras para garantir regularidade, estabilidade ou o uso adequado dos recursos. Porém, como observa Almeida (2005), este controle já esteve presente no período de inflação alta, pois, em tese, garantiria que a vinculação obrigatória de recursos chegaria de fato aos seus beneficiários, a despeito da conjuntura econômica desfavorável.

Numa visão de conjunto, o processo de reformas sociais com impacto federativo atingiu quatro áreas principais de atuação do Estado brasileiro: habitação, saneamento, saúde e educação. Podem ser colocadas como um dos principais objetivos do governo Fernando Henrique Cardoso, ao lado da redução e disciplinização dos gastos públicos (ajuste fiscal) e da modernização da burocracia nos três níveis de governo (uma reforma que podemos nomear de gerencial). Abrucio e Costa, no entanto, argumentam que "de forma mais acentuada do que nas duas outras dimensões da reforma, as mudanças das políticas sociais dependem diretamente da reestruturação das relações intergovernamentais e da constituição de um sistema federativo cooperativo e coordenado.” (Abrucio e Costa, 1998:109). Este último aspecto foi de fato pouco enfrentado no pacote de intenções que resultou nas reformas de programas sociais, associando a mudança no padrão das relações intergovernamentais mais à restrição por condicionamento, do que um processo de cooperação consciente entre níveis de governo.

O que acontece durante o governo de Fernando Henrique Cardoso é que os percentuais de recursos destinados à aplicação direta em áreas sociais, por parte de estados e municípios, ganha impulso. Principalmente por meio de alterações no texto constitucional. Contudo, na área de habitação e sa- 
neamento este não foi o caminho seguido para modificar o modelo vigente. Desta maneira não entraremos em maiores detalhes nestes dois ramos de atuação. ${ }^{45}$

Já as áreas de saúde e educação são especialmente sensíveis do ponto de vista da construção efetiva de um estado de bem-estar, ainda mais num país socialmente desigual e em desenvolvimento. Pois em ambas houve uma prática de constitucionalizar a gestão e a aplicação de recursos, por meio de emendas constitucionais. Mas se o objetivo do governo foi o de atingir objetivos semelhantes, teve de partir de modelos diferentes, conforme consagrados na Constituição de 1988.

Na verdade até de antes dela, pois não houve alterações significativas na estrutura institucional de gestão das políticas sociais que existia no período autoritário. De acordo com Arretche, "mesmo as medidas de reforma aprovadas e implementadas pelos sucessivos presidentes [pós-1988], pouco ou nada alteraram esta estrutura prévia, que é centralizada para as políticas de saúde e desenvolvimento urbano e descentralizada para a política de educação fundamental. No início dos anos 90, a distribuição federativa dos encargos na área social derivava menos de obrigações constitucionais e mais da forma como historicamente estes serviços estiveram organizados em cada política particular. A capacidade de coordenação das políticas setoriais dependeu em grande parte destes arranjos institucionais herdados." (Idem, 2004:22).

Pois na área de saúde, a União tem a função de financiar e formular a política nacional para o setor, assim como coordenar as ações entre os níveis de governo. Na prática este papel cabe ao Ministério da Saúde, que define as regras e as transferências para os governos subnacionais. Desta forma, o governo federal tem a seu dispor recursos institucionais para influenciar as escolhas dos governos subnacionais, com efeitos sobre suas agendas de governo.

\footnotetext{
${ }^{45}$ Mesmo assim podemos resumir as principais alterações. O governo de Fernando Henrique Cardoso procurou modificar o paradigma herdado desde o período do regime militar, basicamente estatal e centralizado. Primeiramente o governo federal adotou como estratégia um plano de desestatização das empresas públicas de habitação e saneamento. Implementou um programa de financiamento das empresas que tivessem capacidade de comprovar que poderiam honrar as dívidas, dando incentivo aos governadores e prefeitos a arrumarem suas contas, para receber os financiamentos. Em complemento ao plano, foram estabelecidas comissões estaduais, nomeadas pelos governadores, com autoridade para distribuir os financiamentos recebidos no interior de cada estado. (Arretche, 2002 e 2004). Se houve certa descentralização - talvez melhor seria dizer, delegação -, o modelo continua a reter para o governo federal o controle sobre a arrecadação e distribuição dos recursos, por meio do Fundo de Garantia por Tempo de Serviço (FGTS), destinado a indenizar trabalhadores demitidos sem justa causa, cuja arrecadação líquida é direcionada para o financiamento da habitação e do saneamento. Além disso, "o conselho gestor do FGTS define as regras de operação dos programas, assim como o agente financeiro do fundo - a Caixa Econômica Federal (CEF) - detém o poder para a autorização definitiva. [Pois] nem o conselho curador do FGTS nem a CEF contam com representação federativa em suas principais instâncias decisórias. (...) [Com isso] o governo federal [tem] razoável autonomia para definir unilateralmente as regras de distribuição dos empréstimos federais." (Arretche, 2004:23).
} 
Através da edição de portarias ministeriais, o governo federal traz incentivos para que os governos subnacionais sigam sua orientação, condicionando, assim, as transferências federais. Assim é que "em maio de 2002, 5.537 dos 5.560 municípios do país - 99,6\% do total - haviam assumido a gestão parcial ou integral dos serviços de saúde. (Ibidem, 2004:22).

Esta estrutura ainda conta com a participação dos estados e municípios na formulação das políticas de saúde, ou seja, não são totalmente passivos. Esta ação ocorre por meio de conselhos com representação dos estados e municípios no Conselho Nacional de Saúde.

Como era a União que tinha a maior parte dos recursos a serem distribuídos para o exercício da gestão do setor nos níveis subnacionais, ela precisava de uma fonte de receita que fosse segura e ficasse à disposição de outros tópicos de seu orçamento. Pois o problema é que a Constituição de 1988 criou um orçamento unificado para aposentadorias, benefícios de assistência social e saúde pública, o chamado orçamento da seguridade social. Pois a fusão destes gastos no mesmo orçamento produziu, ao longo do tempo, um efeito de deslocamento do orçamento da saúde pública. "Isso porque as aposentadorias são desembolsos contratuais, e não são 'comprimíveis'; são fluxos de compromissos futuros que só terminam com a morte dos pensionistas. Em contrapartida os gastos com saúde são, na sua maioria, despesas correntes, sendo, por definição, vulneráveis no contexto da gestão fiscal. [Desta forma], os compromissos previdenciários, ao longo do tempo, comprometeram os gastos com saúde." (Melo, 2005:869).

Com isso o governo propôs que a saúde pública tivesse uma fonte permanente de vinculação de recursos a serem transferidos aos governos subnacionais, garantindo, com isso, que a política do setor fosse realmente aplicada. $\mathrm{O}$ meio encontrado para isso foi a promulgação da emenda constitucional 29, em 13 de setembro de 2000, que estabeleceu valores mínimos para os investimentos em saúde nos três níveis de governo. Para o governo federal, o orçamento de 2000 fixou um aumento de 5\% em relação ao de 1999. Até 2005 o valor dos gastos no setor seria reajustado pela variação anual do PIB nominal, sendo que 15\% deveriam ser direcionados aos procedimentos básicos de saúde pública nos municípios e distribuídos de acordo com a população. Quanto aos estados, $12 \%$ da receita descontadas as transferências aos municípios - devem ser investidos em saúde. Por sua vez, os municípios devem gastar 15\% de seu orçamento em saúde. Os estados e municípios que no ano 2000 tivessem gastos inferiores ao estipulado deveriam reduzir a diferença a uma razão de um quinto por ano. A emenda estabelece ainda que o não cumprimento tornaria possível a intervenção federal nos governos 
subnacionais. Por fim, todas as transferências seriam canalizadas para um fundo sujeito a auditorias. ${ }^{46}$ (Arretche, 2004; Melo, 2005).

Todo este conjunto de medidas - apesar de alguns problemas apontados - tornou possível o objetivo de controlar e assegurar o gasto dos estados e municípios, reduzindo a incerteza sobre os resultados desta política pública, das mais importantes para o governo de Fernando Henrique Cardoso. Como sublinha Melo, "o Executivo prefere vincular o gasto subnacional porque isso lhe concede discricionaridade fiscal no âmbito federal e lhe possibilita superar os problemas de assimetria de informação em relação a agentes na ponta do sistema: prefeitos, governadores e burocracias responsáveis pela implementação.” (Idem, 2005:871).

Este também foi o caso para a política do governo federal para a educação fundamental. Mas, à diferença do caso da saúde, há uma maior descentralização definida em termos constitucionais, pois a oferta de ensino fundamental é de responsabilidade dos estados e municípios. E elas operam de modo inteiramente independente. Esta autonomia de gestão dos governos subnacionais em uma federação que tem entre suas principais marcas a desigualdade socioeconômica, explica as diferenças entre a quantidade de matrículas de um estado para outro, assim como na carreira e salários dos professores. Como exemplo, em 1996, 87,5\% das matrículas eram oferecidas pelo governo estadual de São Paulo, ao passo que em Alagoas e no Maranhão eram os municípios que detinham a maioria das matrículas, no caso de 65\% (Arretche, 2004:23).

Desta maneira a iniciativa do governo em propor uma emenda à Constituição destinada ao planejamento e gastos em educação fundamental, teve por objetivo diminuir as diferenças no interior dos estados e promover uma melhora nos salários dos professores, por meio do Fundo de Manutenção e Valorização do Magistério (Fundef), de iniciativa do poder Executivo e promulgada como a emenda constitucional número 14 em 12 de setembro de 1996.

A Constituição de 1988 já estipulava em seu artigo 212, que a União tem de aplicar 18\% e os estados e municípios $25 \%$ da receita oriunda de impostos, incluindo a originada pelas transferências.

\footnotetext{
${ }^{46}$ Contudo, um relatório do Ministério da Saúde publicado em 2007, revela que apenas sete estados aplicaram corretamente o percentual de $12 \%$ em 2005. Os secretários estaduais da Saúde em geral reclamam que não há clareza sobre o que é gasto com saúde, nos quais alguns entendem, por exemplo, ser gasto em saúde a segurança alimentar e outros o saneamento. Em 2003 o Ministério da Saúde baixou uma resolução definindo os gastos no setor, mas os estados a ignoram por meio das decisões dos Tribunais de Contas dos Estados, a quem cabe a decisão final sobre o assunto. Estima-se que R \$ 5,7 bilhões anuais têm deixado de ser gasto em saúde no país. (Folha de S. Paulo, 11 de março de 2007). Para resolver o problema seria preciso regulamentar a emenda 29 , definindo o que é gasto em saúde.
} 
Mas com a emenda 14, ocorre uma minirreforma tributária de âmbito estadual, pois $15 \%$ das receitas de estados e municípios ficam automaticamente retidas e contabilizadas em um Fundo Estadual - o Fundef. A partir daí, suas receitas são redistribuídas, no interior de cada estado, entre os governos estaduais e seus respectivos municípios, de acordo com o número de matrículas oferecidas anualmente. E o Fundef exigia ainda que, pelos próximos 10 anos a partir de sua promulgação, $60 \%$ dos $25 \%$ dos recursos subnacionais destinados ao setor fossem gastos para pagar os professores no exercício de sua função.

Neste conjunto de medidas, a de maior inovação é aquela que vincula a alocação de recursos à quantidade de matrículas oferecidas. Com isso, os prefeitos empenharam-se em atrair mais alunos porque receberiam mais transferências do fundo. E houve descentralização dos estados para os municípios, pois haveria transferências negativas em alguns municípios caso os serviços educacionais fossem prestados pelos estados. Desta forma, "esta nova estrutura de incentivos produziu dois resultados importantes: criou fortes incentivos para os governos municipais expandirem a cobertura nos seus territórios e encorajou-os a assumirem os serviços educacionais prestados pelos estados." (Melo, 2005:874).

Fica claro que as áreas de saúde e educação foram tratadas com interesse especial pelo governo de Fernando Henrique Cardoso. Tanto é que ambas contaram com ministros da confiança do presidente, os economistas Paulo Renato Souza (Educação, nos dois mandatos) e José Serra (Saúde, em parte do primeiro e segundo mandato), numa espécie de insulamento, ao menos nas estruturas de comando dos ministérios. ${ }^{47}$ Isto tornou possível que imprimissem programas de forma coesa com o Executivo e, desta forma, pudessem transformar a maneira como a União passou a agir em relação às unidades federativas. E como o governo federal não dispunha de recursos institucionais para mudar as escolhas dos governos subnacionais, usou a estratégia de constitucionalizar os encargos, o que se revelou bem-sucedido. Aprovou emendas à Constituição que reduziram a margem de ação dos governos subnacionais, obrigando-os a seguir um comportamento considerado desejável pelo governo federal.

Se por um lado, continua sendo um fato que tanto a educação quanto a saúde tem um longo e árduo caminho para melhorar, principalmente no quesito de qualidade do serviço prestado, afirmamos que para além dos objetivos de melhorar a gestão e a universalização dos serviços em saúde e educação, o governo objetivou também um controle fiscal sobre as escolhas dos estados e municípios. Pois,

\footnotetext{
${ }^{47}$ Marcus André Melo (2005) explora este argumento em detalhes.
} 
especialmente no caso da educação, garantiu que os recursos fossem de fato aplicados de maneira específica e, desta forma, previsível.

\section{Conclusões}

Vimos neste capítulo algumas das principais características do governo do presidente Fernando Henrique Cardoso. Desde os antecedentes - ainda no governo de Itamar Franco - com as mudanças no plano macroeconômico, no plano fiscal e no calendário eleitoral para uma proposta que, no essencial, encerra o período de quase duas décadas de inflação de dois dígitos mensais, que corroía a riqueza, aumentava a desigualdade e prejudicava as perspectivas do pais.

O novo governo que assume neste novo contexto procura imprimir um ritmo agudo de mudanças na estrutura do Estado brasileiro, principalmente no que diz respeito ao tema federativo, enfocado nas relações intergovernamentais. Procurou, assim, redefinir os papéis e as escolhas pertinentes a cada ente federativo, usando para isso o mecanismo das emendas à Constituição. Por este caminho, devido a uma coalizão heterogênea quanto à suas origens e filiação ideológica, mas homogênea quanto aos seus objetivos de governo, tornou o poder Executivo capaz de levar adiante uma série de propostas de emenda, votadas e aprovadas nas duas casas do Congresso Nacional.

Analisamos por meio de seis tabelas as emendas constitucionais aprovadas por todos os governos pós-88 e sob vários pontos de vista, como que poder mais a aprovou, se mais o governo ou a oposição, os temas mais aprovados, com a discriminação em três áreas principais (institucional, econômica e federativa) e, finalmente, dentro da área federativa, discriminamos sub-temas, como fiscal, social, política e governamental. Priorizamos a análise no governo de Fernando Henrique Cardoso sublinhando o seu ímpeto reformista e dentro dele, a reestruturação em torno das funções do Estado e, por extensão, do federalismo.

Desta perspectiva federativa, portanto, podemos afirmar neste momento que o governo federal reverteu sua posição comparativamente desfavorável em relação aos estados e municípios do período pré-1994. Primeiro do ponto de vista da alteração do padrão de distribuição fiscal, com uma redução no nível de autonomia dos governos subnacionais, com a maior retenção de recursos tributários para a União e o processo bem-sucedido de renegociação das dívidas dos estados. E segundo também do ponto de vista social, com a vinculação constitucional de gastos a serem executados por estados e municípios em setores como saúde e educação, sendo passíveis mesmo de intervenção no caso de desobediência. Se de um lado isto pode ser interpretado como a instrumentalização dos meios para a 
concretização da descentralização, pois capacita estados e municípios a aplicar os recursos nestas áreas, por outro também representa uma restrição às suas autonomias administrativas, pois condiciona os seus gastos de maneira obrigatória. E isto segue os interesses explícitos da União, tornando, assim, a federação mais centralizada do ponto de vista das políticas sociais e revertendo, desta forma, parte das conquistas descentralizadoras da Constituição de 1988.

Como veremos no próximo capítulo, o governo federal aumentou seu poder de barganha com o efeito político do êxito do Plano Real, o que o qualificou para negociar em uma posição mais vantajosa com os estados, que passavam por dificuldades financeiras. Contudo, o poder da União não foi (e não é) unilateral, tem limites dentro do ambiente consociativo e de dispersão de poder no interior da federação. Conta para isso, também, além do desenho institucional, as forças do jogo político em si que atuam de maneira ora mais, ora menos favorável em determinada ocasião e conjuntura.

Desta forma, no capítulo quatro voltaremos nossa atenção para as negociações de um tópico federativo por excelência e mesmo decisivo: a questão fiscal. A análise procurará ser realizada da perspectiva das negociações entre o governo federal e os governos dos estados, tendo como fatos os fundos fiscais (Fundo Social de Emergência e suas renovações) e a renegociação das dívidas dos estados. E como locus principal de análise, a atuação e o eventual impacto de veto que pode ser exercido pelo Senado Federal, a casa legislativa de base federativa. 


\section{Capítulo 4}

\section{A atuação do Senado Federal no processo de ajuste fiscal dos}

anos 90

Neste capítulo faremos a análise do desempenho do Senado no processo de negociação das dívidas dos bancos estaduais e da criação do Fundo Social de Emergência (FSE) e suas renovações. Tanto um como outro representam efeitos de um novo ordenamento político e fiscal que a federação brasileira passa a vivenciar a partir de 1994, com a adoção do Plano Real e a posse do presidente Fernando Henrique Cardoso, em 1995. O tema subjacente a esta análise é se, como e de que forma, o Senado brasileiro pode, eventualmente, exercer poder de veto e com isso constranger os interesses dos representantes da maioria da população do país.

Como vimos no capítulo dois, o Senado brasileiro segue um modelo de representação comum a vários outros países, o de um número igual de representantes para cada unidade federativa. O objetivo é o de garantir um mesmo status a cada ente dentro da associação, mas como eles têm um número de população variado, isto termina por sobre-representar aqueles com um número menor de habitantes. No caso brasileiro, em particular, esta questão é mais sensível, devido à grande desigualdade de povoamento existente no país. Além disso há também a desigualdade de renda regional, que segue o mesmo padrão, com as regiões sub-representadas mais ricas e as sobrerepresentadas mais pobres. Afora estes problemas, há também aqueles relativos ao grau de poderes que o Senado brasileiro exerce. De acordo com Stepan (1999), o Senado brasileiro seria um dos mais poderosos entre as democracias federativas. Teríamos um Senado incongruente quanto à fonte de representação em relação à Câmara dos Deputados e moderadamente assimétrico em relação ao exercício de suas atribuições, embora em algumas áreas com muito poder, como no que tange às questões financeiras dos três níveis da federação.

A seguir discutiremos o tema em seqüência cronológica. Primeiro faremos uma exposição sucinta do ambiente político-econômico do país durante a primeira metade dos anos 90, no qual a aprovação e vigência das novas regras constitucionais demarcou uma relação federativa mais favorável aos governos subnacionais. Esta situação foi em parte responsável pelo aumento da crise econômica, no sentido de que os estados gastavam muito acima de suas receitas, endividando-se por meio de seus bancos estaduais e desequilibrando as contas públicas como um todo. As principais 
características deste tipo de relação federativa será analisada, partindo do conceito de federalismo predatório defendido por Fernando Abrucio (1998). Para enfrentar este quadro econômico e politicamente desfavorável, o governo federal cria o Fundo Social de Emergência, no início de 1994, no bojo de um projeto de reorganização macroecômica, que resultará no Plano Real e na eleição de Fernando Henrique Cardoso à Presidência da República no mesmo ano.

Deste momento em diante o quadro mais favorável aos governos subnacionais é alterado. A União se fortalece a partir de medidas concretas como, por exemplo, os fundos fiscais renováveis que retém para ela recursos que seriam repassados aos estados e municípios, a criação e ampliação periódica de tributos como as contribuições sociais, que não precisam ser compartilhados com os estados e municípios e o amplo programa de refinanciamento das dívidas dos estados, que passam a ter a União como única credora. Além desses fatos, como já expomos no capítulo anterior, algumas emendas constitucionais para áreas sociais - como educação e saúde - garantiram recursos a serem utilizados de forma obrigatória pelos governos subnacionais. Todos estes fatos configuram um novo momento da federação brasileira, em que ocorre uma reconcentração de poder político e restrição de autonomia administrativa e fiscal por parte dos estados e municípios. Claro que esta mudança na balança de poder entre os entes federativos não é unilateral mas demarca uma reação da União ao período imediatamente posterior à 1988.

E se a federação tornou-se menos descentralizada é importante compreendermos como se tornaram possíveis alguns aspectos centrais do processo, como o ajuste fiscal, tendo como focos principais, os fundos fiscais e a negociação em torno das dívidas estaduais. E para além das causas principais, a ênfase recairá no comportamento do Senado Federal, a casa legislativa de justificação federativa. E não só por esta razão conceitual, mas por suas características, especialmente agudas do ponto de vista de suas atribuições e do perfil de sua representação. A análise do papel do senado procurará mostrar (ou comprovar) de que forma atuou no processo, ou seja, se defendeu mais os interesses das unidades federativas ou cooperou com os intereses da União, por meio de apoio partidário. E a partir daí, constatarmos uma maior ou menor importância do Senado, tanto nas relações do poder Executivo com o Legislativo, como na interface que esta câmara, em tese, realiza com os interesses dos governos subnacionais.

Esperamos que com esta cronologia e abordagem a partir do ângulo do Senado, possamos entender melhor o desenvolvimento das relações federativas e, por extensão, de aspectos institucionais relevantes da democracia brasileira. 


\section{$O$ contexto descentralizador}

Um dos traços principais da Constituição de 1988 foi a descentralização entre os níveis de governo. De um lado, com relação às suas áreas de atuação e de outro com o aumento dos repasses de recursos fiscais para os estados e municípios. Se em 1985, o Fundo de Participação dos Estados (FPE) e o Fundo de Participação dos Municípios (FPM) chegavam respectivamente a 14\% e 17\% das receitas federais de impostos, em 1993, eles atingiram 21,5\% e 22,5\%. (Leme, 1992:78). Contudo, a partir de 1994 a União reage no sentido de recuperar suas perdas, por meio da estabilização da economia e de um ajuste fiscal.

Esta descentralização esteve vinculada, em boa medida, ao momento político de então, quando os governadores tinham grande legitimidade eletiva e influência nos trabalhos constituintes, e o governo federal havia sido eleito de forma indireta e com pouca atuação na elaboração da Constituição. (Abrucio, 1998; Souza, 2001).

Desta maneira, os governos subnacionais tiveram acesso a um conjunto de recursos financeiros, administrativos e políticos que representou instrumentos poderosos para cooptarem parlamentares no Congresso Nacional em apoio a seus interesses. Pois apesar da descentralização fiscal, a situação financeira dos estados e municípios deteriorou-se ao longo dos anos 80 e início dos 90 colaborando para o agravamento da crise econômica do país. Uma das possíveis razões é que "à medida que o processo de democratização tomava impulso, os novos governadores e prefeitos eleitos procuraram cumprir suas promessas de campanha e conquistar apoios aumentando as despesas de seus governos." (Samuels, 2003a:809).

Este efeito duplo de um processo de descentralização fiscal e grande força política dos governadores em um contexto de grave crise inflacionária tornou o governo federal incapaz de debelar a crise econômica e, além disso, assumir suas responsabilidades no que diz respeito às suas funções administrativas.

Desta forma, sanear as despesas deficitárias em todas as esferas de governo foi um dos principais objetivos do Plano Real, pois era uma das raízes da instabilidade macroeconômica. Um complemento necessário ao processo de estabilização monetária e debilitamento da inflação. (Abrucio e Costa, 1998; Rigolon e Giambiagi, 1999; Samuels, 2003a). 
E para que isso tivesse êxito, dois elementos importantes, entre outros, tiveram destaque. Primeiro a solução da questão das dívidas dos estados, a maior parte dela contraída por meio dos bancos estaduais. E em segundo, a criação de fundos fiscais nos quais a União retivesse parte dos recursos que repassa aos estados e municípios. Ambos os processos em sustento ao Plano Real só foram possíveis porque a relação de força, entre União e governos subnacionais passou a ser mais equilibrada, pendendo mais para a União.

Abrucio (1998), Kugelmas e Sola (2000) classificaram este momento do federalismo brasileiro como predatório, para explicar os efeitos da perda de poder do governo federal em relação aos governos estaduais no alvorecer da redemocratização. A estrutura do sistema político brasileiro, por si mesma já federativa e com tendência à dispersão do poder, favoreceu os poderes dos governadores de estado e a lógica política estadual, conforme vimos no capítulo anterior, com a explanação do conceito de federalismo estadualista.

As instituições funcionaram de tal forma que incentivaram conflitos entre as esferas de governo (tanto de uma esfera para outra, como entre esferas de mesmo nível), mais do que cooperação. ${ }^{48}$ Como visto, esta situação já pôde ser vista no próprio caráter descentralizador da Constituição, com o aumento do repasse de recursos fiscais e o aumento nas atividades dos entes subnacionais. Esta característica pode ser considerada 'predatória', porque desarmonizou, por assim dizer, o relacionamento entre as esferas de governo, com algumas aferindo vantagens comparativas em relação à outras, estabelecendo uma fraqueza relativa do governo federal. ${ }^{49}$

Contudo, se este mesmo conceito procurou explicar a principal característica da federação brasileira a partir da volta da democracia, ele pode ser questionado nos seus próprios termos quando a análise é feita a partir de 1994. Se existia um federalismo predatório a favor dos estados, ele não se mantém com a adoção do Plano Real e dos ajustes fiscais que vieram depois. Melo (2005) vai nesta direção quando afirma que "a visão do federalismo predatório, com um executivo federal fra-

\footnotetext{
${ }^{48}$ Alguém pode dizer que é inerente o conflito entre instituições com objetivos nem sempre coincidentes dentro de um sistema político, especialmente se o regime é democrático e a estrutura do estado é federativa. O que o trabalho de Abrucio procura mostrar é a especificidade deste conflito político brasileiro.

${ }^{49}$ Não podemos esquecer, porém, que o conceito de federalismo predatório não é apenas vertical - entre níveis de governo diferentes, no caso entre a União e os estados -, mas entre níveis de governo equivalentes, no caso, entre os estados, ou entre os municípios. Este segundo caso seria horizontal e se manteria vigente, devido principalmente às alíquotas fiscais diferentes aplicadas por cada estado. Isto incentivaria a chamada 'guerra fiscal' entre eles, ao conceber incentivos fiscais para a instalação de empresas e serviços em seus territórios. Neste trabalho não iremos explorar esta dimensão.
} 
co, incapaz de superar as pressões da periferia do sistema político, é estranha ao quadro do federalismo no governo de Fernando Henrique Cardoso.” (Melo, 2005:854).

Por outro lado, talvez seja possível falar em um federalismo predatório a favor da União, o que reforçaria o argumento da centralização. Veremos, então, se tal conceito se mantém às avessas. Ou se é necessário adotarmos outros critérios e linhas de argumentação para explicar este novo momento no interior da federação brasileira.

A literatura de Ciência Política toma este momento entre 1994 e 1995 - a implantação do Real - como um ponto de inflexão. Como vimos no capítulo anterior, uma série de fatores políticos contribuíram para mudar o curso das relações federativas a partir deste momento. Além disso há os fatores relacionados à questão do plano de ajuste da economia e do aspecto propriamente institucional.

No primeiro aspecto pode ser apontado a qualidade técnica do plano econômico, que vale por si, e gera efeitos independentes do ambiente político e da estrutura das instituições. Já sobre o segundo, a diferença, em termos institucionais, é que o mecanismo de aprovação do Fundo Social de Emergência foi diferente do rito comum, isto é, ocorreu através da Assembléia Nacional Constituinte de Revisão. Como veremos, seu método de composição unicameral de votação tornou mais fácil o trâmite e resultado a favor dos interesses do governo. E isto foi decisivo para anular os eventuais poderes de veto que o Senado poderia exercer.

\section{Ajuste fiscal: dívidas dos estados e fundos fiscais}

Daqui em diante analisaremos cada um dos momentos principais do ajuste fiscal levado a termo pelo governo federal. E do ponto que nós é mais caro, de que maneira o Senado atuou nas negociações entre os entes federativos, tanto com relação às mudanças de alcance constitucional, como também àquelas relativas às dívidas dos estados, em especial o processo de privatização e/ou liquidação dos seus bancos.

Em linhas gerais podemos afirmar que o ajuste fiscal em seu conjunto contemplou dois objetivos econômicos e um político. Os dois primeiros, relacionados à sustentação do processo de estabilização da economia e de forma complementar a tentativa de reverter a perda de flexibilidade na gestão do governo, por causa da excessiva vinculação dos recursos, estabelecidos na Constituição 
de 1988. Já o terceiro, uma reação do governo federal em relação ao poder 'predatório' até então praticado pelos governos estaduais.

Em termos cronológicos o primeiro passo neste processo foi a criação do Fundo Social de Emergência (FSE), aprovado em $1^{\circ}$ de março de 1994, ainda sob o governo de Itamar Franco (19921994). Nesta época o titular do Ministério da Fazenda, era o então senador Fernando Henrique Cardoso (PSDB-SP), que já estava colocando em prática um plano gradativo de estabilização da economia, que entraria formalmente em operação em $1^{\circ}$ de julho do mesmo ano. A principal medida do fundo foi a desvinculação de $20 \%$ de uma grande parcela da receita reservada constitucionalmente ao repasse aos estados e municípios. Na prática isto representaria uma diminuição do total do repasse dos fundos de participação dos estados (FPE) e dos municípios (FPM). E entre os maiores prejudicados estariam os estados das três regiões mais pobres e menos populosas, as do Norte, Nordeste e Centro-Oeste, pois elas ficam com $85 \%$ do total destes fundos. Justifica-se, portanto, sabermos como votaram estas regiões em uma matéria de interesse para elas, mesmo que o Senado não tenha podido atuar.

O FSE foi aprovado como a primeira emenda dentro do cronograma de revisão da Constituição, previsto para acontecer depois de cinco anos de sua promulgação, em 1993. Mas esta revisão ocorreu um ano depois de prevista e terminou por não acontecer na amplitude esperada, consagrando apenas seis modificações. Além do FSE, a redução do mandato de cinco para quatro anos para o presidente da República. ${ }^{50} \mathrm{O}$ roteiro destas emendas ocorreu através de votação por maioria absoluta (metade mais um) dos membros do Congresso Nacional, em sessão unicameral, em dois turnos de votação. Ou seja, seguiu um caminho diferente do estabelecido para as demais alterações da Constituição, como estabelece o seu artigo 60, em que são necessárias duas votações nominais em cada casa do Congresso e aprovação por maioria de $3 / 5$ em cada votação. ${ }^{51}$ Certamente este mecanismo tornou mais ágil a tramitação e votação da emenda - durou apenas um mês -, o que ajudou os objetivos imediatos do governo em busca do ajuste das contas públicas federais.

\footnotetext{
${ }^{50}$ Esta foi a emenda constitucional de revisão de número cinco. As demais alterações foram a convocação de ministros pelo Congresso (Emenda no.2); a dupla nacionalidade do brasileiro em determinados casos e facilitação da requisição da nacionalidade brasileira por estrangeiros (Emenda no.3); aumento dos casos de inelegibilidade (Emenda no.4) e suspenção dos efeitos da renúncia do parlamentar submetido a processo que vise ou possa levar à perda do mandato. (Emenda no.6).

${ }^{51}$ Curiosamente, David Samuels (2003a e 2003b) não percebeu esta diferença, quando explica em seus dois textos que as mudanças teriam de vencer a "ditadura dos $3 / 5$ ".
} 
Mas antes de expormos como foram feitas as negociações em torno do apoio (e oposição) à aprovação do FSE, cabe destacar o fato institucional em si, qual seja, que as duas votações em sessão unicameral, somando os votos dos deputados e senadores $(513+81=594)$, anulou o poder de veto que o Senado poderia eventualmente exercer. Do ponto de vista federativo isto é mais que simbólico: os parlamentares eleitos para representarem seus estados ficaram impedidos de exercer tal poder. Para efeitos práticos, podemos dizer que a casa federativa foi incorporada pela casa do povo. Na votação de uma proposta que afeta diretamente os interesses das unidades da federação, esta anulação é relevante. Ainda mais por causa dos chamados poderes demos constraining que estariam presentes no Senado.

Mesmo assim podemos analisar a partir das votações, qual foram os resultados e como se comportaram os senadores. Claro que uma análise como esta não é a mesma do que uma feita com o processo regular (bicameral e duas votações de 3/5), pois as condições políticas em que são realizadas passam a ser outras e os atores levam em conta este dado em suas ações. Contudo, creio que através dos resultados seja possível recuperar - ao menos em parte - como poderia ter sido o processo, se seguidas as condições normais. E, finalmente, por meio disto, averiguarmos se o Senado aprovaria ou não a promulgação da emenda.

O primeiro passo é verificar se o resultado das votações atingiu os três quintos do processo normal. A emenda constitucional número 1 teve duas votações. A primeira foi realizada no dia 9 de fevereiro de 1994, como uma emenda aglutinativa. O resultado foi o seguinte: Sim 388; Não 38; Abstenções 4 e Total de 430 votos.

Lembremos que este resultado ocorreu em torno dos parlamentares presentes. Assim, se o total é de 594, tivemos 164 ausentes. Desta forma, votaram a emenda 72,39\% dos parlamentares. Dentro deste universo, o "sim" representou 90,23\% dos votos. Muito acima da maioria mínima de $50 \%+1$ requerida neste caso e também se fosse de uma emenda normal, de maioria qualificada de três quintos - com uma margem de aprovação de 30,23\%. Já se tomarmos como base o total de votos favoráveis com relação ao total dos parlamentares, o índice chega a 65,32\%. Este número aprovaria a emenda em maioria absoluta e por uma margem de 5,32\% para uma votação de maioria qualificada, requerida numa emenda comum. No fundo, o que chama a atenção é a quantidade elevada de parlamentares ausentes desta votação. Isto poderia ser compreendido como um sinal de rejeição da emenda? Pois em tese, seria menos custoso ao parlamentar não comparecer e declarar seu voto em plenário. Em parte este argumento é válido, mas temos de considerar que pode haver outros mo- 
tivos para o não comparecimento, conforme veremos a seguir. Em todo o caso, mesmo que se ocorresse pelo mecanismo normal a emenda seria aprovada.

Tabela 4.1 - Votação em primeiro turno do Congresso Nacional da Emenda Constitucional de Revisão no. 1 (relativa ao FSE) - 9/2/1994.

\begin{tabular}{|c|c|c|c|c|c|}
\hline PARTIDO & POSIÇÃO & SIM & NÃO & ABS. & TOTAL \\
\hline $\begin{array}{l}\text { PFL/PSC/ } \\
\text { PRS } \\
\text { (bloco) }\end{array}$ & Coalizão & 104 & 6 & 1 & 111 \\
\hline PMDB & Coalizão & 101 & 10 & 2 & 113 \\
\hline $\mathrm{PP}$ & Coalizão & 45 & 1 & 0 & 46 \\
\hline PSDB & Coalizão & 56 & 0 & 0 & 56 \\
\hline PDC & Apoio & 2 & 1 & 0 & 3 \\
\hline PDS & Apoio & 1 & 1 & 0 & 2 \\
\hline $\mathrm{PL}$ & Apoio & 17 & 0 & 0 & 17 \\
\hline PMN & Apoio & 1 & 0 & 0 & 1 \\
\hline PPR & Apoio & 41 & 15 & 1 & 57 \\
\hline PTB & Apoio & 7 & 0 & 0 & 7 \\
\hline PRN & Apoio & 5 & 1 & 0 & 6 \\
\hline PSD & Apoio & 8 & 1 & 0 & 9 \\
\hline Total 1 & ----- & 388 & 36 & 4 & 428 \\
\hline PC do B & Oposição & --- & --- & --- & 0 \\
\hline PDT & Oposição & 0 & 1 & 0 & 1 \\
\hline PPS & Oposição & --- & --- & --- & 0 \\
\hline PRONA & Oposição & 0 & 1 & 0 & 1 \\
\hline PSB & Oposição & --- & --- & --- & 0 \\
\hline PSTU & Oposição & --- & --- & --- & 0 \\
\hline PT & Oposição & --- & --- & --- & 0 \\
\hline PV & Oposição & --- & --- & --- & 0 \\
\hline Total 2 & ----- & 0 & 2 & 0 & 2 \\
\hline Total $1+2$ & $\overline{----}$ & 388 & 38 & 4 & 430 \\
\hline
\end{tabular}


Fonte: Elaboração própria, a partir do site da Câmara dos Deputados (www.camara.gov.br) e Figueiredo, 2006.

A tabela acima mostra o resultado da votação do ângulo da clivagem entre os que apóiam o governo e a oposição. Do primeiro lado, estão os partidos que formalmente faziam parte da coalizão: PMDB, PP, PSDB e o bloco formado pelo PFL, PSC e PRS. Além destes, há os partidos conservadores que também apoiavam o governo, o que pode ser verificado pela indicação de voto do líder de cada um destes partidos, recomendando a seus pares um voto favorável à aprovação da emenda: PDC, PDS, PL, PMN, PPR, PTB, PRN, PSD. De outro, os partidos de oposição, que se alinham ao centro e/ou à esquerda do espectro ideológico, como o PDT, PC do B, PPS, PSB, PT e PV. Repare que o PRONA está alinhado a estes partidos, embora não seja um partido de esquerda. É que o seu único voto foi contrário à aprovação da emenda.

Como era de se esperar o governo conseguiu a totalidade de seus votos entre os partidos da coalizão e os conservadores. Contudo, chama a atenção dois fatos: primeiro que 36 dentre estes votaram contra, o que representa $8,41 \%$ dos parlamentares que apoiavam a emenda. A principal razão foi a liberação da bancada do PPR, por parte de seu líder, o deputado Marcelino Romano Machado (PPR-SP). ${ }^{52}$ Isso ocorreu porque o partido sentiu-se prejudicado em suas intenções de preservar um acordo com o governo que previa a manutenção de gasto de $18 \%$ para a educação e $20 \%$ para a habitação do total dos recursos a serem arrecadados com o FSE. O PPR queria que estas matérias fossem votadas de forma separada, mas foram votos vencidos pelas outras lideranças partidárias que apoiavam o governo, que preferiram votar o conjunto de uma só vez. ${ }^{53}$

E em segundo lugar a quase absoluta ausência dos votos da oposição, que se recusaram a votar. Em plenário, os líderes do PC do B, PDT, PPS, PSB, PSTU, PT e PV declaram-se em "obstrução" e pediram a seus colegas que saíssem do plenário. O motivo alegado pelos líderes, em especial Miro Teixeira (PDT-RJ) e José Genoíno (PT-SP), é que a presidência do Congresso, na figura do senador Humberto Lucena (PMDB-PB), lhes impediu de apresentar destaques de votação em separado, pois isso favorecia os interesses do governo. O motivo partidário pode ser levado em conta mas, em termos técnicos isso aconteceu através de uma interpretação do Regimento Interno que a-

\footnotetext{
${ }^{52}$ Cabe notar que outro fator limitante à autonomia dos senadores é que os partidos indicaram o voto "sim" ou "não", por meio de uma liderança em plenário. E na grande maioria dos casos os líderes eram deputados.

${ }^{53}$ O deputado Marcelino Romano Machado era aliado do prefeito de São Paulo na época, Paulo Maluf (PPR), que tinha pretenções de concorrer à Presidência naquele ano. A defesa desta pauta também seria motivada pelos interesses eleitorais de Maluf.
} 
firmava o caráter de excepcionalidade desta emenda, por se tratar de uma revisão constitucional, justificando a impossibilidade de apresentação de destaques. ${ }^{54}$

Tabela 4.2 - Votação em primeiro turno do Congresso Nacional da Emenda Constitucional de Revisão no. 1 (relativa ao FSE), do ponto de vista das regiões do país.

\begin{tabular}{|l|c|c|c|c|c|c|c|}
\hline Região/Posição & \multicolumn{3}{|c|}{ Coalizão + Apoio } & \multicolumn{3}{c|}{ Oposição } & \multirow{2}{*}{ Total } \\
\cline { 1 - 7 } Voto & SIM & NÃO & ABS. & SIM & NÃO & ABS. & \\
\hline Norte & 62 & 5 & 0 & 0 & 0 & 0 & 67 \\
\hline Nordeste & 123 & 8 & 3 & 0 & 1 & 0 & 135 \\
\hline Centro-Oeste & 43 & 2 & 0 & 0 & 0 & 0 & 45 \\
\hline Sudeste & 113 & 8 & 1 & 0 & 1 & 0 & 123 \\
\hline Sul & 47 & 13 & 0 & 0 & 0 & 0 & 60 \\
\hline Total & 388 & 36 & 4 & 0 & 2 & 0 & 430 \\
\hline
\end{tabular}

Fonte: Elaboração própria, a partir do site da Câmara dos Deputados (www.camara.gov.br) e Figueiredo, 2006.

Nesta tabela desagregamos os votos da coalizão e seus apoiadores e a oposição segundo uma clivagem regional. Ela se justifica por causa do enfoque analítico que estamos dando ao Senado, mesmo que neste caso esta instituição esteja misturada com a Câmara dos Deputados. O objetivo é verificar se mesmo neste rito unicameral e de maioria absoluta, é possível algum impacto das regiões com relação aos resultados da votação. O que se percebe é que o voto "sim"dos deputados e senadores das regiões mais pobres, menos populosas e sobre-representadas foi elevadíssimo: 92,31\%. E que a região Sul foi a única onde ocorreu alguma controvérsia, com 21,67\% de votos "não". Contudo, a motivação não foi os interesses federativos, mas aqueles já mencionados em defesa de índices percentuais mínimos para a educação e habitação. Ilustração disso é que destes 13 votos contrários, nove foram do PPR, que lutava por esta causa específica.

Já a segunda rodada de votação da emenda aconteceu no dia 24 de fevereiro de 1994, com o seguinte placar: Sim 402; Não 95; Abstenções 3 e Total de 500 votos.

\footnotetext{
${ }^{54}$ Como explicam Figueiredo e Limongi (1999:108), “em votações de matérias constitucionais, o número de votações nominais pode multiplicar-se devido à apresentação de destaques para votação em separado (DVS), tanto das emendas apresentadas como das partes destacadas do texto integral."
} 
Desta vez o número de comparecimento aumentou, representando $84,17 \%$ do total. Dentro deste universo, o "sim" equivale ao índice de 80,40\%. É um valor menor do que o do primeiro turno, mas ainda assim aprovou a emenda por larga margem, tanto pela regra em pauta - a de maioria absoluta -, como se fosse pela maioria qualificada de três quintos. Neste caso, a folga seria de $20,40 \%$. Se levarmos em consideração o total de parlamentares aptos a votar, o percentual de aprovação cai para $67,68 \%$, ou seja, 7,68\% a mais do que o necessário, caso a regra de votação fosse de maioria qualificada.

Tabela 4.3 - Votação em segundo turno do Congresso Nacional da Emenda Constitucional de Revisão no. 1 (relativa ao FSE) - 24/2/1994.

\begin{tabular}{|l|c|c|c|c|c|}
\hline PARTIDO & POSIÇÃO & SIM & NÃO & ABS. & TOTAL \\
\hline $\begin{array}{l}\text { PFL/PSC/ } \\
\text { PRS } \\
\text { bloco) }\end{array}$ & Coalizão & 116 & 4 & 1 & 121 \\
\hline PMDB & Coalizão & 96 & 11 & 2 & 109 \\
\hline PP & Coalizão & 49 & 1 & 0 & 50 \\
\hline PSDB & Coalizão & 54 & 0 & 0 & 54 \\
\hline PDC & Apoio & 2 & 0 & 0 & 2 \\
\hline PDS & Apoio & 1 & 1 & 0 & 2 \\
\hline PL & Apoio & 16 & 0 & 0 & 16 \\
\hline PMN & Apoio & 1 & 0 & 0 & 1 \\
\hline PPS & Apoio & 3 & 0 & 0 & 3 \\
\hline PPR & Apoio & 44 & 16 & 0 & 60 \\
\hline PTB & Apoio & 5 & 0 & 0 & 5 \\
\hline PRN & Apoio & 6 & 2 & 0 & 8 \\
\hline PSD & Apoio & 7 & 2 & 0 & 9 \\
\hline Total 1 & ----- & 400 & 37 & 3 & 440 \\
\hline PDT & Oposição & 2 & 24 & 0 & 26 \\
\hline PSB & Oposição & 0 & 2 & 0 & 2 \\
\hline PT & Oposição & 0 & 31 & 0 & 31 \\
\hline PV & Oposição & 0 & 1 & 0 & 1 \\
\hline
\end{tabular}




\begin{tabular}{|l|c|c|c|c|c|}
\hline Total 2 & ----- & 2 & 58 & 0 & 60 \\
\hline Total $1+2$ & ---- & 402 & 95 & 3 & 500 \\
\hline
\end{tabular}

Fonte: Elaboração própria, a partir do site da Câmara dos Deputados (www.camara.gov.br) e Figueiredo, 2006.

No segundo turno houve algumas alterações em relação ao primeiro turno, a principal delas a presença da oposição no plenário declarando o seu "não", principalmente por parte dos dois maiores partidos, o PT e o PDT. Entre os votos contrários, repete-se o padrão do primeiro turno entre os partidos que apoiavam informalmente o governo, o caso do PPR, no qual novamente a mesma questão voltou em pauta. Como não atendeu aos objetivos de parte do partido, a bancada foi liberada e isso representou 16 votos contrários de um total de 60 que compareceram, um índice de 26,67\%, ainda maior do que o primeiro turno. Registre-se também entre os partidos formalmente de esquerda, que o PPS havia votado "não" no primeiro turno, mas mudou de posição e votou "sim" no segundo. Na verdade, o partido havia inicialmente declarado apoio no primeiro turno, mas mudou de posição pouco antes do voto, por causa da polêmica em torno da aceitação ou não de votações de destaques em separado.

Tabela 4.4 - Votação em segundo turno do Congresso Nacional da Emenda Constitucional de Revisão no. 1 (relativa ao FSE), do ponto de vista das regiões do país.

\begin{tabular}{|l|c|c|c|c|c|c|c|}
\hline Região/Posição & \multicolumn{3}{|c|}{ Coalizão + Apoio } & \multicolumn{3}{|c|}{ Oposição } & \multirow{2}{*}{ Total } \\
\hline Voto & SIM & NÃO & ABS. & SIM & NÃO & ABS. & \\
\hline Norte & 63 & 5 & 0 & 0 & 4 & 0 & 72 \\
\hline Nordeste & 129 & 10 & 2 & 0 & 13 & 0 & 154 \\
\hline Centro-Oeste & 42 & 3 & 0 & 0 & 1 & 0 & 46 \\
\hline Sudeste & 117 & 10 & 1 & 1 & 28 & 0 & 157 \\
\hline Sul & 49 & 9 & 0 & 1 & 12 & 0 & 71 \\
\hline Total & 400 & 37 & 3 & 2 & 58 & 0 & 500 \\
\hline
\end{tabular}

Fonte: Elaboração própria, a partir do site da Câmara dos Deputados (www.camara.gov.br) e Figueiredo, 2006.

No segundo turno, repete-se o padrão do primeiro com relação às três regiões menos desenvolvidas e populosas, com um índice de apoio ao FSE de 86,03\%. Um pouco menor do que o do 
primeiro turno, mas explicável pelo comparecimento da oposição em plenário. Já com relação as duas regiões mais desenvolvidas, a região Sul diminuiu um pouco o percentual de "não" em relação ao total, ficando em $18,31 \%$. A novidade é a região Sudeste, pois se no primeiro turno o percentual de votos contrários ficou em $7,32 \%$, no segundo saltou para $24,20 \%$, quase um quarto do total dos parlamentares que votaram. A causa é a presença dos dois maiores partidos de oposição na votação, o PT e o PDT. Contudo, esta mudança expressiva na região mais rica e mais sub-representada não significa que ocorreu por causa da defesa dos interesses federativos. A justificativa da oposição certamente adotou o discurso de defesa dos interesses de estados e, principalmente, municípios. Mas esta postura ocorreu por causa da disputa partidária entre governo e oposição. Como veremos adiante nas próximas votações, quando na oposição, adota-se o discurso de defesa dos interesses daqueles que, teoricamente, são os prejudicados. E quanto aos partidos conservadores, em tese mais alinhados com a proposta do governo, o destaque novamente foi a postura do PPR, com oito votos "não" na região Sul - o nono foi do PP - , o que perfaz 18,37\% em relação ao total dos votos da coalizão e seus apoiadores. Este é um valor menor em 9,29\% do obtido no primeiro turno, mas ainda assim é expressivo.

O resultado dos dois turnos de votação mostra que não só a exigência por maioria absoluta, mas também a de três quintos seria alcançada, a despeito do número relativamente alto de ausências, especialmente na primeira votação. Seria possível afirmar, então, que a mudança para regras menos rigorosas nem teriam sido necessárias? Os números mostram que sim. Mas é preciso considerar que a tramitação de uma proposta de emenda constitucional pelo processo normal é muito mais lenta, sujeita a negociações e mais pontos de vetos. E uma instituição decisiva em termos institucionais e de defesa dos interesses federativos ficou, por assim dizer, fora do jogo, o Senado Federal.

Isso porque os senadores ficaram diluídos junto aos deputados numa sessão unicameral. Em si, este fato anula o eventual poder de veto que eles poderiam exercer com relação à emenda, pois encontram-se em uma quantidade bem menor que os deputados. De um total de 594 parlamentares, os senadores representam apenas 13,64\%. E mesmo se estivessem reunidos juntos em uma mesma sessão, mas votando de forma separada e identificada e com seus respectivos poderes de veto resguardados $^{55}$ - uma sinalização de manutenção da simetria bicameral -, não seria o mesmo que deliberarem e votarem em sua própria instituição e num momento distinto. Neste caso teriam de levar

\footnotetext{
${ }^{55}$ Como visto no capítulo dois, este é o caso quando ocorre sessões de votações conjuntas no Congresso.
} 
em consideração a votação anterior ou posterior da Câmara. Mesmo com estas ressalvas, é oportuno sabermos como votaram os senadores.

Como podemos observar nas tabelas 4.5 e 4.6, de um total de 81 aptos a participar do processo, 55 votaram no primeiro e no segundo turno $(67,90 \%)$. Se tivessem poder de veto, este percentual seria suficiente para vetar, tanto numa votação por maioria absoluta, como por maioria qualificada.

Mas qualquer interpretação que pudesse concluir que os interesses federativos foram prejudicados, porque os senadores se posicionaram contra a emenda mas estavam com seus direitos obstruídos, está longe da realidade. Isso porque, tanto no primeiro, como no segundo turno a maioria deles votou a favor do governo. Seguindo os números das tabelas 4.5 e 4.6, no primeiro, o "sim" foi de $51,92,73 \%$ do total dos presentes e de $62,96 \%$, se levarmos em conta também os ausentes. Já no segundo turno, o "sim" foi declarado em plenário por 47 senadores, 88,68\% dos presentes e por $58,02 \%$, levando em conta os ausentes. Este último dado é interessante, pois, teoricamente, se em condições em que o Senado tivesse seus poderes, ficaria abaixo dos $60 \%$ necessários para aprovar a emenda.

Em todo caso é possível afirmar que a ausência de 25 senadores no primeiro e 25 no segundo turno signifique uma rejeição ao FSE? Pouco provável, embora seja possível que alguns senadores tenham utilizado deste recurso para expressar seu descontentamento. Ou desestímulo, já que o Senado enquanto instituição perdeu valor no processo. Talvez tenham calculado ainda que o não comparecimento evitaria um desgaste junto ao seu partido ou aos seus eleitores. Ou não faria diferença, pois o número de senadores que apoiavam formalmente o governo era de 58 (71,60\%), além de outros partidos conservadores que o apoiavam também. Mas mesmo assim, a ausência causaria poucos problemas, já que a maior parte dos votantes é de deputados (513 no total), sendo que 284 estavam na coalizão - 55,27\% -, além de alguns votos adicionais dos já citados partidos conservadores. Finalmente, possa ter ocorrido razões outras, como motivos de ordem pessoal para a ausência. 
Tabela 4.5 - Votação em primeiro turno dos senadores da Emenda Constitucional de Revisão no. 1 (relativa ao FSE) - 9/2/1994.

\begin{tabular}{|l|c|c|c|c|c|c|}
\hline PARTIDO & POSIÇÃO & SIM & NÃO & ABS. & AUSENTE & TOTAL \\
\hline PFL & Coalizão & 11 & 2 & 0 & 7 & 20 \\
\hline PMDB & Coalizão & 18 & 1 & 1 & 6 & 26 \\
\hline PP & Coalizão & 3 & 0 & 0 & 0 & 3 \\
\hline PSDB & Coalizão & 9 & 0 & 0 & 0 & 9 \\
\hline PDC & Apoio & 2 & 0 & 0 & 0 & 2 \\
\hline PDS & Apoio & 1 & 1 & 0 & 1 & 3 \\
\hline PPR & Apoio & 0 & 0 & 0 & 1 & 1 \\
\hline PTB & Apoio & 5 & 0 & 0 & 1 & 6 \\
\hline PRN & Apoio & 2 & 0 & 0 & 3 & 5 \\
\hline Total 1 & ----- & 51 & 4 & 1 & 19 & 75 \\
\hline Sem partido & ----- & 0 & 0 & 0 & 1 & 1 \\
\hline PDT & Oposição & 0 & 0 & 0 & 3 & 3 \\
\hline PSB & Oposição & 0 & 0 & 0 & 1 & 1 \\
\hline PT & Oposição & 0 & 0 & 0 & 1 & 1 \\
\hline Total 2 & ----- & 0 & 0 & 0 & 5 & 5 \\
\hline Total 1 + 2 & ---- & 51 & 4 & 1 & 25 & 81 \\
\hline
\end{tabular}

Fonte: Elaboração própria, a partir do site da Câmara dos Deputados (www.camara.gov.br) e Figueiredo, 2006. 
Tabela 4.6 - Votação em segundo turno dos senadores da Emenda Constitucional de Revisão no. 1 (relativa ao FSE) - 24/2/1994.

\begin{tabular}{|l|c|c|c|c|c|c|}
\hline PARTIDO & POSIÇÃO & SIM & NÃO & ABS. & AUSENTE & TOTAL \\
\hline PFL & Coalizão & 10 & 2 & 0 & 8 & 20 \\
\hline PMDB & Coalizão & 17 & 2 & 1 & 6 & 26 \\
\hline PP & Coalizão & 2 & 0 & 0 & 1 & 3 \\
\hline PSDB & Coalizão & 7 & 0 & 0 & 2 & 9 \\
\hline PDC & Apoio & 2 & 0 & 0 & 0 & 2 \\
\hline PDS & Apoio & 1 & 1 & 0 & 1 & 3 \\
\hline PPR & Apoio & 0 & 0 & 0 & 1 & 1 \\
\hline PTB & Apoio & 4 & 0 & 0 & 2 & 6 \\
\hline PRN & Apoio & 4 & 1 & 0 & 0 & 5 \\
\hline Total 1 & ----- & 47 & 6 & 1 & 21 & 75 \\
\hline Sem partido & ----- & 0 & 0 & 0 & 1 & 1 \\
\hline PDT & Oposição & 0 & 1 & 0 & 2 & 3 \\
\hline PSB & Oposição & 0 & 0 & 0 & 1 & 1 \\
\hline PT & Oposição & 0 & 1 & 0 & 0 & 1 \\
\hline Total 2 & ----- & 0 & 2 & 0 & 3 & 5 \\
\hline Total 1 + 2 & ---- & 47 & 8 & 1 & 25 & 81 \\
\hline
\end{tabular}

Fonte: Elaboração própria, a partir do site da Câmara dos Deputados (www.camara.gov.br) e Figueiredo, 2006.

Nesta altura, assim como efetuado linhas acima para o conjunto do Congresso, é oportuno avaliarmos os resultados dos votos dos senadores a partir de suas regiões, isto é, uma interpretação do ponto de vista federativo. As tabelas 4.7 e 4.8 a seguir ilustram a questão. 
Tabela 4.7 - Votação em primeiro turno dos senadores da Emenda Constitucional de Revisão no. 1 (relativa ao FSE), do ponto de vista das regiões do país.

\begin{tabular}{|c|c|c|c|c|c|c|c|c|c|}
\hline Região/Posição & \multicolumn{4}{|c|}{ Coalizão + Apoio } & \multicolumn{4}{|c|}{ Oposição } & \multirow[b]{2}{*}{ Total } \\
\hline Voto & SIM & NÃO & ABS & AUS & SIM & NÃO & ABS & AUS & \\
\hline Norte & 16 & 1 & 0 & 4 & 0 & 0 & 0 & 0 & 21 \\
\hline Nordeste & 15 & 3 & 1 & 7 & 0 & 0 & 0 & 1 & 27 \\
\hline Centro-Oeste & 7 & 0 & 0 & 4 & 0 & 0 & 0 & 0 & $11 *$ \\
\hline Sudeste & 7 & 0 & 0 & 2 & 0 & 0 & 0 & 3 & 12 \\
\hline Sul & 6 & 0 & 0 & 2 & 0 & 0 & 0 & 1 & 9 \\
\hline Total & 51 & 4 & 1 & 19 & 0 & 0 & 0 & 5 & 80 \\
\hline
\end{tabular}

Fonte: Elaboração própria, a partir do site da Câmara dos Deputados (www.camara.gov.br) e Figueiredo, 2006.

* Obs.: O senador Antonio Alves (Goiás), sem partido e ausente, não foi incluído em nenhuma das duas posições.

Tabela 4.8 - Votação em segundo turno dos senadores da Emenda Constitucional de Revisão no. 1 (relativa ao FSE), do ponto de vista das regiões do país.

\begin{tabular}{|c|c|c|c|c|c|c|c|c|c|}
\hline Região/Posição & \multicolumn{4}{|c|}{ Coalizão + Apoio } & \multicolumn{4}{|c|}{ Oposição } & \multirow[b]{2}{*}{ Total } \\
\hline Voto & SIM & NÃO & ABS & AUS & SIM & NÃO & ABS & AUS & \\
\hline Norte & 14 & 1 & 0 & 6 & 0 & 0 & 0 & 0 & 21 \\
\hline Nordeste & 15 & 4 & 1 & 6 & 0 & 1 & 0 & 0 & 27 \\
\hline Centro-Oeste & 8 & 0 & 0 & 3 & 0 & 0 & 0 & 0 & $11^{*}$ \\
\hline Sudeste & 7 & 1 & 0 & 1 & 0 & 1 & 0 & 2 & 12 \\
\hline Sul & 3 & 0 & 0 & 5 & 0 & 0 & 0 & 1 & 9 \\
\hline Total & 47 & 6 & 1 & 21 & 0 & 2 & 0 & 3 & 80 \\
\hline
\end{tabular}

Fonte: Elaboração própria, a partir do site da Câmara dos Deputados (www.camara.gov.br) e Figueiredo, 2006.

* Obs.: O senador Antonio Alves (Goiás), sem partido e ausente, não foi incluído em nenhuma das duas posições.

As duas tabelas indicam com segurança que os senadores aprovariam o FSE, a despeito de seus impactos aos entes federativos, em especial os do Norte, Nordeste e Centro-Oeste. Na tabela 
4.7 vemos que dos 60 representantes destas três regiões, que poderiam vetar sem precisar do voto de 27 deles numa emenda constitucional pelo processo normal, 38 deles votaram "sim" $(88,37 \%$ dos presentes e $63,33 \%$ do total). Já na tabela 4.8 os valores são quase iguais, pois 37 votaram "sim" (84,09\% dos presentes e 61,67\% do total das regiões). Os últimos dados, referentes à quantidade de votos favoráveis em relação ao total é interessante, pois indica que nos dois turnos a grande ausência de parte deles, diminuiu a adesão final das regiões em torno da aprovação da emenda. Veja que no primeiro turno, 20 senadores não contribuíram para a aprovação, sendo que 15 foram ausentes (25\%). No segundo turno, os valores foram muito semelhantes: 22 senadores não referendaram o FSE, sendo que 16 deles (26,67\%) não compareceram ao plenário. Isso também quer dizer que se são necessários 33 votos para vetar a aprovação da emenda, no primeiro turno faltou 11 votos e no segundo turno dez votos para que isso ocorresse.

As poucas divergências - vistas nas tabelas 4.1, 4.2, 4.3 e 4.4 - que ocorreram em algumas regiões do país, como a Sul no primeiro turno e a Sul e Sudeste no segundo, estão menos visíveis. Por três razões. Primeiro porque o número de senadores é muito inferior ao de deputados para todos os estados. Segundo porque eles foram mais favoráveis ao governo do que os deputados. Repare que na região Norte, por exemplo, nos dois turnos, dos 21 senadores apenas um votou contra em cada turno. E nem houve coerência, pois não foi o mesmo. No primeiro turno, Cesar Dias (PMDBRR) votou contra e no segundo a favor. Já o senador Amir Lando (PMDB-RO) votou a favor no primeiro e contra no segundo. Pelo exame das duas tabelas vemos a inexistência de qualquer defesa de interesses federativos ou regionais em termos concretos, ou seja, através do voto. Também cabe destacar que em termos partidários o tamanho da oposição é muito pequeno, com apenas cinco senadores de um total de $81(6,17 \%)$.

Tendo à disposição os resultados acima é possível dizer que o governo aprovou o FSE com facilidade? Não necessariamente, pois é preciso analisar como ocorreram as negociações prévias para se chegar a este resultado.

Do ponto de vista da relação entre a União e as unidades federativas, o processo de negociação ocorreu através da condição de que os estados não receberiam menos transferências fiscais do que o ano de 1993, ou seja, imediatamente anterior à aprovação do FSE. O governo federal conseguiria reter $20 \%$ do que teria de compartilhar com estados e municípios, mas estes não perderiam receitas, tendo como base o ano anterior. Para resolver esta questão, a União, que inicialmente pro- 
pusera uma desvinculação de $15 \%$, chegou aos $20 \%$, com a condição de que aumentaria as alíquotas do Imposto de Renda em 5,6\% e 100\% da receita vinda do imposto de renda dos servidores públicos federais não entrariam neste cálculo de não partilhamento. ${ }^{56}$ Esta medida não alterou o fato de que o valor da desvinculação permaneceu o mesmo, isto é, 20\%. Mas teve a intenção de aumentar o valor absoluto do repasse. Que no entanto seria maior, caso estes novos aumentos de alíquotas ocorressem sem a retenção dos recursos. De qualquer maneira, esta iniciativa da União contribuiu para que os governadores não colocassem mais empecilhos à aprovação do FSE. ${ }^{57}$

Em termos concretos, ao examinarmos o texto da emenda aprovado verificamos que o fundo era composto por até $86,2 \%$ da arrecadação do ITR e - como já citado - até 5,6\% da arrecadação do Imposto de Renda. Além disso, há fontes que provinham da arrecadação derivada da elevação da alíquota da Contribuição Social sobre o Lucro Líquido das Pessoas Jurídicas (CSLL). E por fim ainda "retinha $20 \%$ da arrecadação de todos os impostos e contribuições da União, aí compreendidas as transferências constitucionais a estados e municípios”. (Arretche, 2007:8).

Portanto, a despeito da garantia de que os estados e municípios não receberiam menos valores absolutos do que o ano anterior à aprovação, o FSE impôs perdas aos estados e municípios, pois combinou de forma simultânea a desvinculação de gastos da União com retenção de parte das receitas dos fundos constitucionais, por dois anos, 1994 e 1995.

Contudo, o caráter transitório do fundo é um fator a ser considerado, pois ele não é permanente como, teoricamente, se disporia a ser um texto de conteúdo constitucional. Esta transitoriedade está relacionada pelo tema ser bastante sensível às relações federativas, a repartição dos tributos.

\footnotetext{
${ }^{56}$ É importante lembrar que a fonte para a retirada dos recursos fiscais a serem transferidos aos estados e municípios vem de $47 \%$ do que é arrecadado pelo Imposto de Renda (IR) mais o Imposto sobre Produtos Industrializados (IPI). Se separamos por entes federativos, a União transfere para os estados, 21,5\% do IR e IPI, $10 \%$ do IPI (do Fundo de Compensação pela Exportação de Produtos Industrializados - FPEX), 30\% do Imposto sobre Operações Financeiras sobre o Ouro (IOF-Ouro) e o imposto de renda retido na fonte dos servidores estaduais. Já para os municípios, a União transfere 22,5\% do IR e do IPI, 50\% do Imposto sobre a Propriedade Rural (ITR), 70\% do IOF-Ouro e o imposto de renda retido na fonte dos servidores municipais. Há ainda a transferência de 3\% do IR e IPI para os fundos regionais, que auxiliam as regiões Norte, Nordeste e Centro-Oeste. E, por fim, os estados transferem aos municípios $25 \%$ do Imposto sobre a Circulação de Mercadorias e Serviços (ICMS) e 50\% do Imposto sobre a Propriedade de Veículos Automotores. (Brasil, Ministério da Fazenda, 2002a).

${ }^{57}$ Estes empecilhos relacionavam-se às perdas que os estados teriam. De acordo com Samuels (2003a), para conseguir o apoio dos governadores junto aos parlamentares para a aprovação do FSE também houve avanços nas negociações em torno das dívidas dos estados que, nos próximos anos, seria incorporada pela União. Contudo, não há evidências empíricas de que esta negociação tenha se convertido em apoio na hora de votar a emenda ou mesmo de que os estados tenham recebido algum alívio na renegociação de suas dívidas, como veremos adiante. A observação de Samuels se resume portanto a afirmar que as negociações eram concomitantes.
} 
Desta maneira, a emenda que aprovou o FSE contém uma cláusula de vigência limitada, que expirou e foi renovada por três vezes no governo Fernando Henrique Cardoso (em 1995, 1997 e 2000) e foi renovada em dezembro de 2003 e com prazo de encerramento em dezembro de 2007 no governo Lula. Ou seja, é uma emenda de caráter temporal, que necessita de renovação periódica. E isso ajuda a entender a razão pela qual o Congresso a aceitou desde o início: "porque não era e não é uma reforma permanente das relações fiscais entre as esferas de governo." (Samuels, 2003a:823).

\section{Os estados e seus bancos deficitários}

Como estamos seguindo uma linha cronológica no que se refere ao ajuste fiscal, antes de passarmos à análise da primeira renovação do FSE, é importante nos determos no processo de renegociação das dívidas dos estados com seus bancos estaduais, que aconteceu no fim de 1994.

Só para termos uma idéia do quadro em que se encontravam os estados e municípios, a piora dos seus resultados fiscais contribuiu para o agravamento do quadro fiscal do Brasil durante os anos 80 e parte dos 90 . Os governos subnacionais responderam por $35 \%$ da deterioração - o que representa 5,2\% do PIB - do resultado operacional somado entre os períodos de 1990-1994 e 1995-1998. (Rigolon e Giambiagi, 1999:28). Uma consequiência dos déficits elevados dos governos subnacionais foi o crescimento exponencial de suas dívidas. ${ }^{58} \mathrm{E}$ os mesmos autores constatam que "a dívida líquida desses governos aumentou ininterruptamente, de 5,8\% do PIB em 1989 para 14,4\% em 1998. A sua participação na divida líquida do setor público passou de apenas $15 \%$ em 1989 para 39\% entre 1995 e 1998." (Idem, 1999:28).

Em 1993, 25 dos 27 estados brasileiros (incluindo o Distrito Federal) controlavam pelo menos uma instituição financeira. E esses bancos tornaram mais difícil a situação econômica do país, porque os governadores usavam os bancos com objetivos não-econômicos. Tomavam empréstimos altos para cobrir despesas deficitárias e devido aos seus objetivos políticos de ocasião, geralmente não pagavam os empréstimos, o que prejudicava a situação financeira dos bancos e piorava o contexto fiscal em seu conjunto. Contudo, em decorrência da força política dos governadores eles conseguiam renegociar suas dívidas com os bancos por meio de intervenção do Banco Central. Este intervia provisoriamente nas instituições, arrumava suas contas e os devolvia aos estados. E mais adiante contraiam novas dívidas com 'seus' bancos e o processo reiniciava.

\footnotetext{
${ }^{58}$ Relatório do Banco Central informa que entre 1991 e 1996 a dívida aumentou de R \$ 72.022 bilhões para R\$ 133.693 bilhões. (Mora, 2002:8).
} 
Mônica Mora (2002) ressalta que a importância de alguns desses bancos, como o Banespa (de São Paulo), o Banerj (do Rio de Janeiro) e o Bemge (de Minas Gerais) levava o Banco Central a realizar estas operações para impedir que a insolvência destes tivesse repercussão em todo o sistema financeiro. Tanto é que o saneamento dos bancos, através do Programa de Apoio à Reestruturação e ao Ajuste Fiscal dos Estados (PROES) e da lei 9.496/97, absorveu em torno de R \$ 50 bilhões, um sinal da importância que tinham como instrumentos do financiamento dos estados.(Mora, 2002:2829).

Pois o enquadramento dos bancos e das finanças estaduais era dificultada pela autonomia relativa dos estados conferidas pela Constituição de 1988. Por este motivo, a paralização deste verdadeiro moto-contínuo entre estados $\rightarrow$ bancos estaduais $\rightarrow$ banco central $\rightarrow$ estados $\rightarrow$ bancos estaduais $\rightarrow$..., exigia um processo de negociação dos mais complexos entre as esferas de governo. E isso só seria possível se o governo federal pudesse ter força política para enfrentar os governos estaduais.

Desta maneira, dentro desta nova conjuntura, o governo federal adquiriu mais capacidade de lidar com a questão do ajuste fiscal, como parte do plano de estabilização da economia. E este processo incluía em boa medida a renogociação das dívidas dos estados e, em especial, dos bancos estaduais. De saída é preciso ter em mente que com o funcionamento do Plano Real a situação financeira dos estados piorou ainda mais, porque os juros foram muito aumentados, com o objetivo de controlar a inflação. A partir de 1995 a maior parte dos bancos estaduais sofre intervenção do Banco Central. Mas ao contrário do que ocorria antes, eles, depois de saneados, não foram devolvidos aos governos estaduais, com o risco de recomeçar um novo ciclo de endividamento. Desta feita, a intervenção tinha por intenção privatizá-los, transformá-los em agências de fomento ou extinguilos.

Neste processo uma das questões mais sensíveis foi a intervenção e destino dado ao Banespa, o principal banco estadual do país. Sua intervenção e as extensas negociações posteriores para definir um destino à instituição serviu de modelo ao que seria feito com as demais instituições financeiras dos outros estados. De acordo com Garman, Leite e Marques (2001), o objetivo inicial do governo federal era privatizar o banco. Imediatamente aconteceram manifestações contrárias para que isto não se realizasse. Elas partiram, principalmente, do governo do estado ${ }^{59}$, da bancada paulis-

\footnotetext{
${ }^{59}$ Vale lembrar que a intervenção no Banespa, como também no Banerj - Banco do estado do Rio de Janeiro - , foi realizada em 30 de dezembro de 1994, a dois dias da posse dos novos governadores dos dois estados. Tanto o governador
} 
ta no Congresso Nacional, onde dos seus 73 representantes (70 na Câmara e 3 no Senado), apenas quatro eram favoráveis à privatização, e também da Assembléia Legislativa, no qual 9 dos 94 parlamentares hesitavam entre apoiar ou não a privatização. (Idem, 2001). Também setores empresariais pressionaram, além de representantes das instituições econômicas do estado de São Paulo, em especial da Federação Agrícola. Segundo o Departamento Intersindical de Estatística e Estudos Sócio-Econômicos (DIEESE), 85,5\% de todas as operações de crédito com o setor rural eram conduzidos por bancos estaduais e $96 \%$ das operações de crédito rural estavam a cargo do Banespa.

Esta oposição ao objetivo de privatização do Banespa teria se cristalizado sob a forma de ameaça no Congresso Nacional. Os deputados federais paulistas ameaçaram obstruir projetos importantes do governo federal - e nisso ainda contavam com apoio da bancada ruralista. Note-se que esta oposição cruzava as fronteiras partidárias e unia parlamentares que estivessem ou não na coalizão.

O deputado Maluly Neto (PFL-SP), por exemplo, anunciou que "se o governo federal não negociar com a bancada paulista o destino do Banespa, nós vamos rechaçar o que o Executivo mandar para o Legislativo.” (Ibidem, 2001:54). Já o deputado Nelson Marquezelli (PTB-SP), líder da bancada ruralista na Câmara, declarou que "toda a bancada ruralista, ao todo 120 deputados, faria oposição a uma eventual privatização." (Ibidem, 2001:54). ${ }^{60}$

Já no Senado a obstrução também foi relevante, mas fruto de outra fonte de interesse. Os senadores das três regiões menos populosas e economicamente desfavorecidas, Norte, Nordeste e Centro-Oeste, com maioria e poder de veto de alcance constitucional (60 senadores, 27 a mais que o necessário para vetar qualquer mudança), declararam oposição à privatização do Banespa porque temiam que os bancos de seus estados não tivessem o mesmo tratamento que o banco do estado mais importante do país estava recebendo. Ou seja, temiam um destino pior que a privatização para seus bancos.

Covas (de São Paulo), como Marcelo Alencar (do Rio de Janeiro) pertenciam ao PSDB, mesmo partido do presidente. Ambos foram receptivos porque estavam diante de um fato consumado, além de liberados do ônus de medidas com custos políticos - como reduzir o número de agências e demitir funcionários - que ficariam a cargo do Banco Central. Contudo, depois do governo federal sinalizar a intenção de privatizar os bancos, Covas passou a fazer oposição, enquanto Alencar foi mais favorável. Para um relato pormenorizado, ver Garman, Leite e Marques (2001:50-53).

${ }^{60}$ Além disso, foram criadas duas comissões suprapartidárias na Câmara dos Deputados em oposição à privatização. Detalhes em Garman, Leite e Marques, 2001:54. 
Esta situação provocou a criação de uma Comissão Parlamentar de Inquérito (CPI) do sistema financeiro, não para investigá-lo em si, mas para servir de apoio à demanda dos senadores destas regiões (Ibidem, 2001:55). As negociações no Senado para aprovar os termos do acordo da dívida do estado de São Paulo com a União somente progrediram quando o representante da Comissão de Assuntos Econômicos do Senado (CAE), Gilberto Miranda (PMDB-AM), apoiou uma proposta do senador Ney Suassuna (PMDB-PB) para garantir tratamento similar na negociação das dívidas e destino aos bancos para todos os estados. "O líder do governo no Senado, Élcio Álvares (PFL-ES), com o aval do presidente Fernando Henrique Cardoso, então garantiu que o governo federal proveria crédito similar para todos os bancos comerciais estaduais com problemas financeiros, garantia esta que forneceu a espinha dorsal do programa de reestruturação dos bancos estaduais, criado nos três meses seguintes à votação do caso Banespa.” (Ibidem, 2001:55-56).

Em síntese, tais ações tornaram possível a renegociação da dívida de São Paulo com um Banespa sob intervenção federal, o que abriu espaço para que, de um lado o Banco Central adquirisse força e experiência para negociar com os demais estados, e de outro que os demais bancos tivessem um tratamento similar ao do caso paulista, embora isto não fosse garantia para um destino semelhante. Abrucio e Costa resumem: "Sabendo que a negociação com São Paulo era fundamental para a União, os deputados [paulistas] e os senadores de outros estados, em maioria no Congresso Nacional, barganharam melhores condições por meio da ameaça de obstrução às negociações com o governo paulista." (Abrucio e Costa, 1998:85). ${ }^{61}$

O que temos claro é que dentro deste caminho de reestruturação das dívidas dos estados, com foco na situação dos bancos estaduais, é preciso lembrar que não houve uma injeção de moeda em termos literais, mas sim uma troca de dívidas, isto é, o governo federal assumiu as dívidas dos estados com seus bancos, tornando-se um único credor para todos eles. Se isto ocasionou um ônus para a União, pois aumentou sua dívida interna e as dificuldades para gerenciá-la em consonância com o processo de ajuste fiscal, por outro lado, os estados passaram a ter obrigações com a União, que dentro do acordo estabelecido, deve ser honrado, pois em contrário, podem perder o direito ao repasse de verbas garantidas em termos constitucionais.

\footnotetext{
${ }^{61}$ É possível ponderar que tais anúncios públicos de ameaças fazem parte de um jogo, no qual os diferentes atores declaram suas intenções no sentido de obterem vantagens para si e/ou os grupos que representam. Não é possível termos certeza se agiriam de fato como declararam se seus interesses viessem - no caso presente - a ser contrariados. A articulação política de setores em apoio (ou oposição) a uma medida e uma declaração posterior sinalizam aos atores sobre a suposta intenção de cada um. E os demais contendores levam em conta esta informação em suas próximas ações. Ou seja, podemos dizer que as articulações políticas e suas eventuais declarações são mais do que um jogo de cena, embora não possam ser consideradas decisivas para o desfecho de uma negociação entre grupos políticos com interesses diversos.
} 
Em seu conjunto este "refinancimento das dívidas teve o mérito de estabelecer um projeto global, especialmente em uma federação marcada pela fragmentação e atitudes centrífugas por parte dos governos subnacionais." (Abrucio e Costa, 1998:86). E este arcabouço estruturou-se em quatro pontos principais: (1) quitação das dívidas via privatização das empresas estatais; (2) cumprimento de cláusulas mais rígidas de desempenho fiscal; (3) penalidades para os que não cumprirem regularmente com os pagamentos e (4) assunção pela União de dívida que seria difícil de ser refinanciada, pagando preços muito altos no mercado.

Estes quatro pontos restringiram a autonomia dos estados, pois lhes tirou recursos que seriam gastos segundo seus interesses para o pagamento de dívidas, além da alienação de parte importante de seu patrimônio ${ }^{62}$ e a ameaça do não repasse de tributos, em caso do não cumprimento do acordo. Contudo, a situação dos estados não era a mesma. Deve ser notado que os 27 estados que compõem a federação não devem ser tratados como homogêneos, isto é, como se todos tivessem os mesmos interesses e partilhassem a mesma situação quer com relação às suas dívidas, quer quanto a situação dos seus bancos. Os estados podem ser distinguidos entre os mais e os menos endividados, assim como entre os com maior ou menor capacidade de honrar suas dívidas. Há os mais autônomos do ponto de vista fiscal e os mais dependentes dos repasses do governo federal.

É o que ressalta Mora (2002), ao afirmar que o acordo para os pagamentos da dívida "não significou necessariamente a uniformização dos acordos assinados pelos estados, a despeito de algumas regras comuns a todos eles. A flexibilidade na elaboração dos acordos permitiria, sem ferir as prerrogativas federativas, considerar a capacidade dos estados em corresponder às exigências contratuais e respeitar, dentro de limites preestabelecidos, as diferenças horizontais, intrínsecas a um país marcado pela heterogeneidade como o Brasil.” (Mora, 2002:25). Assim é que, por exemplo, $90 \%$ dos recursos destinados ao refinanciamento - pouco mais de $\mathrm{R} \$ 100$ bilhões - estava concentrado nos quatro estados mais desenvolvidos e mais autônomos, portanto, a contrair dívidas: São Paulo (dívida assumida de R \$ 61 bilhões), Rio de Janeiro (R 18 bilhões), Minas Gerais (14,4 bilhões) e Rio Grande do Sul (R \$ 10,9 bilhões). (Idem, 2002:27).

Em balanço, a União não logrou negociar o Banespa em uma condição diferente da que queria para os demais bancos e também arcou com os custos de assumir como um único credor os débi-

\footnotetext{
${ }^{62}$ Os acordos de refinanciamento exigiam que os estados pagassem $20 \%$ do total à vista. Para isso, na maioria dos protocolos de contrato, os estados se comprometiam a privatizar suas empresas de energia elétrica. A obrigação de privatizar uma empresa de um setor específico (e estratégico) é um sintoma da perda de força dos estados.
} 
tos dos estados. Por outro lado ela literalmente enquadrou-os em condições rígidas e seguras para receber suas prestações. Lembremos que além do bloqueio das transferências constitucionais dos Fundos de Participação, consta também a possibilidade de bloqueio das receitas tributárias dos próprios estados, o Imposto sobre Circulação de Mercadorias e Serviços (ICMS), que é a principal fonte de arrecadação dos governos estaduais, pelo menos daqueles mais desenvolvidos economicamente. Por fim, o fato é que os estados perderam seus bancos. Um recurso poderoso de financiamento de seus gastos e grupos a ele vinculados, investimentos e usos com objetivos não-econômicos.

\section{Papel do Senado}

Antes de retornarmos a uma análise da criação e manutenção dos fundos fiscais é importante ponderar que um dos maiores obstáculos ao cumprimento do acordo da dívida dos estados encontrava-se na instituição do legislativo de cunho federativo, o Senado Federal. Vimos acima que os senadores tiveram papel ativo no processo de harmonização do tratamento das dívidas dos estados com seus bancos e do destino a que estes teriam. Mas a função do Senado vai além, pois uma de suas atribuições exclusivas que o torna especialmente forte, é que todos os acordos na área financeira dos três entes federativos passam por sua aprovação. Condições de financiamento interno e externo e fixar os limites de endividamento, entre outras atribuições, conforme consta na Constituição, artigo 52, incisos V, VI, VII, VIII, IX e XV. ${ }^{63}$

A análise da função do Senado no estabelecimento de normas de controle do endividamento público - que é a sua área de atuação mais importante -, remete à discussão dos efeitos das instituições sobre os resultados da ação governamental e sobre a estratégia dos atores políticos. E, como acrescenta Maria Rita Loureiro (2001), "remete ainda às condições políticas que permitem, ou não, o efetivo cumprimento das regras institucionais, no contexto de conflitos federativos e constrangimentos macroeconômicos." (Loureiro, 2001:54).

O problema possível é que este mesmo Senado que aprova as restrições ao endividamento é o mesmo composto pelos representantes dos estados. Em tese, diante de "uma crise em seus estados de origem, os senadores, por questão de sobrevivência política, podem alterar as normas que eles mesmos criaram." (Abrucio e Costa, 1998:90).

\footnotetext{
${ }^{63} \mathrm{O}$ Senado brasileiro tem 15 áreas de atuação privativa, sendo seis delas (40\%) para assuntos econômicos.
} 
Nesse sentido Loureiro procurou investigar a atuação do Senado no processo de ajuste fiscal durante o primeiro governo de Fernando Henrique Cardoso, em especial no processo de renegociação das dívidas estaduais. Se, como uma casa federativa, agiu em defesa dos interesses dos estados, que os senadores representam ou de acordo com os objetivos do governo federal em ajustar as contas fiscais (pelo menos os senadores integrantes da coalizão, 66,67\% do total entre os anos de 1995 e 1998 e de $79,01 \%$ de 1999 a 2003).

Em seu trabalho ela mostra que o Senado equilibrou-se, digamos assim, entre as duas tendências. Ora, como vimos acima, eles defenderam seus estados no processo de renegociação dos bancos. Mas também agiram em consonância com o governo federal, ao delegarem - de forma inédita - poderes para o Banco Central. Tal fato aconteceu através da Resolução 78/98 que, entre suas principais modificações, destaca o papel que passa a exercer o Banco Central. "É que este não mais encaminhará ao Senado Federal o pedido de autorização para a contratação de qualquer operação de crédito de governo que possua resultado primário negativo." (Idem, 2001:56). É como se os senadores tivessem reconhecido as 'fraquezas políticas' a que estão sujeitos em resistir às pressões de governadores, de outros parlamentares e seguimentos da sociedade, transferindo, assim, porção relevante de seu poder decisório na área de endividamento para o Banco Central. ${ }^{64}$

Loureiro conclui que "as regras legais, especialmente em matéria fiscal, não bastam para garantir sua efetividade e, daí, cumprir seu papel nas políticas públicas. Elas pressupõem certas condições políticas. No caso em estudo, as normas estabelecidas pelo Senado só começaram a ser implementadas em um contexto político bem determinado: quando se consolida o consenso em torno da responsabilidade fiscal e sobretudo quando o governo federal ganha mais força nas relações federativas." (Ibidem, 2001:59).

\footnotetext{
${ }^{64}$ O que levou o Senado a baixar esta resolução foi a chamada crise dos precatórios em novembro de 1996. Três anos antes foi promulgada a emenda constitucional número 3 que, por seis anos, só permitiria a emissão de títulos públicos por parte de estados e municípios para o refinanciamento de dívidas anteriores. Mas tinha como exceção o financiamento para pagar precatórios judiciais, ou seja, dívida de particulares contra o poder público decididas em juízo. Como lembra Loureiro, a emissão de títulos públicos para pagar precatórios "significava, na prática, criar uma dívida nova, [pois] essa foi a única brecha deixada na legislação para o financiamento dos estados e municípios. Ela foi usada, ao máximo, pelos governos subnacionais como fonte 'adicional' de financiamento público. E permitiu, inclusive, muita irregularidade, o que levou à instalação, em novembro de 1996, de uma CPI.” (Loureiro, 2001:56). A resolução do Senado teve como objetivo disciplinar o comportamento fiscal das unidades federativas, mas com a delegação de poderes para uma instituição não federativa e não sujeita às mesmas pressões políticas, o Banco Central.
} 


\section{Fundo de Estabilização Fiscal 1}

Ao contrário da emenda que aprovou o Fundo Social de Emergência, sua primeira renovação, renomeada de Fundo de Estabilização Fiscal (FEF), acontece através do processo legislativo regular da Constituição. Recapitulando, temos o envio de uma Proposta de Emenda à Constituição (PEC) para uma das casas do Congresso e votação em dois turnos na Câmara e no Senado. Para cada uma destas quatro votações é preciso a aprovação de no mínimo 3/5 dos parlamentares (60\%) para a emenda ser promulgada. A partir de agora, portanto, os mecanismos institucionais são mais difíceis, lentos e sujeitos a pontos de veto, o que obriga os interessados a negociarem mais para conseguirem seus objetivos.

Neste caso, a proposta do Executivo iniciou sua tramitação na Câmara dos Deputados em 15 de agosto de 1995 onde ficou três meses e foi enviada para o Senado em 22 de novembro. Da entrada nesta casa até a promulgação passou-se mais quatro meses, com a promulgação ocorrendo em 4 de março de 1996. Leve-se em conta o recesso entre o fim do ano e o começo do próximo. Um período total, portanto, de sete meses.

Inicialmente o governo propôs um prazo de quatro anos para sua vigência e queria diminuir as transferências para os governos subnacionais, assim como quando foi aprovado o FSE. Pois tal qual o texto que aprovou o primeiro fundo fiscal em 1994 este também contempla que parte dos recursos deve ser investido em saúde e educação, além do fato mais importante de que os $20 \%$ de desvinculação aprovado no FSE foi mantido. Contudo, nesta edição acontece um corte concreto no repasse dos tributos para os estados e municípios. Isso porque o cálculo para a desvinculação de receitas da União passa a ocorrer antes do cálculo de repartição de receita, ou seja, as transferências constitucionais.

Para uma verificação mais precisa do que foi modificado de uma emenda para outra, cabe um comparação do texto de cada uma delas. Desta maneira, a diferença observada nos dois textos é que no texto da emenda 10, no parágrafo IV, inciso terceiro, o artigo 158, II da Constituição - que trata do que pertence aos municípios - é retirado dos impostos a serem retidos pela União. Ou seja, isso significou que 50\% do Imposto sobre a Propriedade Territorial Rural (ITR) permaneceria com 
os municípios. ${ }^{65}$ Vejamos, então, como se deu o processo de tramitação na Câmara e no Senado, procurando averiguar como o FEF foi apreciado especialmente pela casa federativa.

Como dito acima, a proposta do governo deu entrada primeiro na Câmara dos Deputados, onde foi classificada como a PEC 163/1995. Foi encaminhada para a Comissão de Constituição e Justiça e Cidadania (CCJC) para o início da tramitação. Esta comissão é o primeiro forum de análise de uma PEC. Ela existe tanto na Câmara como no Senado e para chegar à votação em plenário é necessário que seja aprovada primeiro nesta comissão. Discute-se essencialmente o valor constitucional da proposta apresentada e é onde ocorre as possíveis primeiras alterações do texto original, por meio de apresentação de emendas. Este é o primeiro ponto de veto de uma PEC, pois se for aqui derrotada ela é dada como encerrada, só podendo ser reenviada na próxima sessão legislativa, ou seja, no ano seguinte.

$\mathrm{Na}$ CCCJ a proposta do governo é aprovada pelo relator Ney Lopes (PFL-RN), apesar de votos contrários de deputados do PMDB, principalmente do Nordeste, e de deputados de partidos de oposição situados no Sul e Sudeste, como os do PT, PDT, PC do B e PSB. Em 12 de setembro a PEC é encaminhada para uma Comissão Especial (CE), que permanece com o mesmo relator da comissão anterior. Também nesta nova comissão, se a proposta for derrotada ela é arquivada, da mesma maneira que a primeira. Tem-se aqui, portanto, um segundo ponto de veto, antes da chegada ao plenário. Nesta nova comissão, a proposta é novamente aprovada. Os mesmos partidos de oposição que a haviam rejeitado antes, novamente o fazem agora.

Contudo, a proposta do governo é modificada no interior destas duas comissões, pois o prazo inicial apresentado era de 4 anos para a vigência do fundo. Através de negociações com o Executivo e os partidos que o apoiavam, reduz-se o prazo para 18 meses, de $1^{\circ}$ de janeiro de 1996 a 30 de junho de 1997. (Arretche, 2007:9).

Entra em plenário para discussão e votação em primeiro turno de $1^{\circ}$ a 8 de novembro de 1995. Nesta semana, foram apresentados nove destaques de votação em separado (DVS), pedidos pelos partidos de oposição, o PT, PDT e PSB. ${ }^{66}$ Tinham como intenção reduzir ainda mais o prazo

\footnotetext{
65 Segundo Samuels (2003b:187, citando O Estado de S. Paulo, de 10 de junho, 16 de junho e 20 de junho de 1997), parte desta vitória dos prefeitos talvez possa ser atribuída à grande presença deles em Brasília para pressionar diretamente os deputados.

${ }^{66}$ Como visto na nota 54 , há dois tipos de destaques para votação em separado: emendas ao texto destacadas para serem votadas separadamente e destaques para votar separadamente parte dos textos.
} 
de vigência do fundo (um ano no máximo) e diminuir pontualmente um ou outro ítem da emenda, ou seja, os ganhos da União em relação aos estados e municípios. Já os partidários do governo argumentaram que os estados e municípios tiveram ganhos fiscais com o Plano Real, motivo pelo qual a retenção de $20 \%$ de suas receitas de transferências não traria perdas líquidas de receitas. Mas como estas DVS foram derrotadas, a proposta que foi para votação em primeiro turno foi a consolidada na CE. Desta maneira, o resultado foi: Sim 345; Não 91; Abs. 5 e Total de 441. Em termos percentuais, isso representa 78,23\% de Sim (67,25\% para o total de 513 deputados); 20,63\% de Não $(17,74 \%)$ e comparecimento de $85,96 \%$ do total. A PEC foi aprovada em primeiro turno com uma margem de folga de $7,25 \%$ sobre o total da casa.

O texto aprovado foi enviado para a $\mathrm{CE}$ a fim de ser redigido para a votação em segundo turno, que acontece nos dias 21 e 22 de novembro. Afora a votação propriamente dita, são votados mais três DVS apresentados pelo PT, novamente sobre aspectos pontuais, que não alteram de forma substantiva o texto, mas mesmo assim os destaques são rejeitados. O placar do segundo turno foi: Sim 348; Não 101; Abs. 9 e Total de 458. Em termos percentuais, isso representa 75,98\% de Sim (67,84\% para o total de 513 deputados); $22,05 \%$ de Não (19,69\%) e comparecimento de 89,28\% do total. Neste caso, a PEC foi aprovada com 7,84\%, um pouquinho maior do que no primeiro turno.

A seguir a PEC chega ao Senado (com o número 68/1995) em 22 de novembro e é enviada no dia seguinte para a sua Comissão de Constituição e Justiça (CCJ). Aqui reinicia-se a apreciação do conteúdo constitucional da proposta e ela, em tese, pode ser rejeitada por maioria dos votos dos participantes da comissão, o que a daria por arquivada, mesmo depois de ter sido aprovada em dois turnos pela Câmara. ${ }^{67}$ Mas a proposta - que tem como relator Jáder Barbalho (PMDB-PA) -, é aprovada no dia 24 de janeiro, com votos contrários de senadores de partidos de oposição, o PSB, PT e PPS, além de parlamentares da coalizão pertencentes ao Norte e Nordeste, como o PSDB-PB, PFL-BA e PTB-TO. Assim como no caso das comissões da Câmara, houve uma indicação de contrariedade com os objetivos do fundo por parte das regiões que mais perdem com a retenção de parte dos Fundos de Participação.

No plenário ocorre apenas uma votação no primeiro turno. A tabela abaixo resume o resultado.

\footnotetext{
${ }^{67}$ Contra esse parecer, pode haver recurso, mas se não houver, a proposta é rejeitada. Detalhes nos regimentos internos de cada câmara. No Senado, o $\S 1^{\circ}$ do art. 101 e na Câmara, os artigos. 202, especialmente caput e $\S 1^{\circ}$. E também o artigo 203 , o 54 e o 132 .
} 
Tabela 4.9 - Votação em primeiro turno do Senado Federal da Emenda Constitucional no. 10 (relativa ao FEF) - 13/2/1996.

\begin{tabular}{|l|c|c|c|c|c|c|}
\hline PARTIDO & POSIÇÃO & SIM & NÃO & ABS. & AUSENTE & TOTAL \\
\hline PFL & Coalizão & 19 & 1 & 0 & 1 & 21 \\
\hline PMDB & Coalizão & 16 & 0 & 1 & 3 & 20 \\
\hline PSDB & Coalizão & 11 & 0 & 1 & 1 & 13 \\
\hline PTB & Coalizão & 4 & 0 & 0 & 2 & 6 \\
\hline PPB & Apoio & 4 & 0 & 0 & 2 & 6 \\
\hline PPS & Apoio & 2 & 0 & 0 & 0 & 2 \\
\hline Total 1 & ------ & 56 & 1 & 2 & 9 & 68 \\
\hline PDT & Oposição & 3 & 3 & 0 & 0 & 6 \\
\hline PSB & Oposição & 0 & 2 & 0 & 0 & 2 \\
\hline PT & Oposição & 1 & 4 & 0 & 0 & 5 \\
\hline Total 2 & ----- & 4 & 9 & 0 & 0 & 13 \\
\hline Total 1 + 2 & ----- & 60 & 10 & 2 & 9 & 81 \\
\hline
\end{tabular}

Fonte: Elaboração própria, a partir do site do Senado Federal (www.senado.gov.br) e Figueiredo, 2006.

Os votos favoráveis representaram 83,33\% (74,07\% em relação ao total de 81). Já os contrários ficaram em $13,89 \%(12,35 \%)$ e $88,89 \%$ dos senadores estiveram em plenário. Como se percebe, estes números são mais expressivos que os da câmara em seus dois turnos. Ou seja, no primeiro turno no Senado, a PEC foi aprovada com uma margem de 14,07\%. Com relação ao comportamento dos integrantes da coalizão - afinal os responsáveis em aprovar a PEC -, vemos que 56 votaram “sim”, o que significa $94,92 \%$ dos presentes e $82,35 \%$ do total. Índices altos, mesmo com um voto "não" e nove ausências.

Com números tão eloqüentes, talvez não fosse necessário analisarmos estes resultados do ponto de vista de uma clivagem regional e/ou federativa. Porém, por se tratar de uma casa legislativa justificada neste princípio faz-se oportuno tal verificação, conforme nos mostra a próxima tabela. 
Tabela 4.10 - Votação em primeiro turno do Senado Federal da Emenda Constitucional no. 10 (relativa ao FEF), do ponto de vista das regiões do país.

\begin{tabular}{|l|c|c|c|c|c|c|c|c|c|}
\hline Região/Posição & \multicolumn{4}{|c|}{ Coalizão + Apoio } & \multicolumn{4}{c|}{ Oposição } & \multirow{2}{*}{ Total } \\
\hline Voto & SIM & NÃo & ABS & AUS & SIM & NÃO & ABS & AUS & Torte \\
\hline Norte & 0 & 1 & 4 & 1 & 3 & 0 & 0 & 21 \\
\hline Nordeste & 22 & 1 & 1 & 1 & 0 & 2 & 0 & 0 & 27 \\
\hline Centro-Oeste & 9 & 0 & 0 & 2 & 0 & 1 & 0 & 0 & 12 \\
\hline Sudeste & 6 & 0 & 0 & 2 & 1 & 3 & 0 & 0 & 12 \\
\hline Sul & 7 & 0 & 0 & 0 & 2 & 0 & 0 & 0 & 9 \\
\hline Total & 56 & 1 & 2 & 9 & 4 & 9 & 0 & 0 & 81 \\
\hline
\end{tabular}

Fonte: Elaboração própria, a partir do site do Senado Federal (www.senado.gov.br) e Figueiredo, 2006.

Vamos repetir a análise que fizemos das tabelas 4.7 e 4.8. Mas neste caso os senadores votaram de forma separada, como uma instituição própria, e com condições reais de veto. Centrando a análise nas três regiões sobre-representadas, vemos que dos seus 60 representantes, 53 compareceram $(88,33 \%)$. Destes, 44 votaram "sim" (83,02\% dos presentes e 73,33\% do total). São números que deixam claro a adesão dos senadores desta região à proposta do governo. Os números acima deixam claro que os votos discordantes ocorreram a partir da oposição e não das bancadas estaduais (ou regionais), principalmente das regiões que foram as mais prejudicadas, as do Norte, Nordeste e Centro-Oeste. Dos 21 senadores do Norte, por exemplo, três dos quatro votos da oposição votaram "não". No Nordeste, os dois oposicionistas votaram contra. No Centro-Oeste, o único da oposição confirmou o esperado. E nas duas regiões mais desenvolvidas, o padrão foi semelhante, embora na região Sul, todos os senadores votaram a favor, mesmo os dois da oposição.

No segundo turno, a discussão e posterior votação aconteceu entre os dias 27 e 29 de fevereiro. Novamente, não foram apresentados destaques para votação em separado. Assim, partiu-se diretamente para a votação final, com o seguinte resultado: 
Tabela 4.11 - Votação em segundo turno do Senado Federal da Emenda Constitucional no. 10 (relativa ao FEF) - 29/2/1996.

\begin{tabular}{|l|c|c|c|c|c|c|}
\hline PARTIDO & POSIÇÃO & SIM & NÃO & ABS. & AUSENTE & TOTAL \\
\hline PFL & Coalizão & 17 & 0 & 0 & 3 & 20 \\
\hline PMDB & Coalizão & 15 & 0 & 0 & 5 & 20 \\
\hline PSDB & Coalizão & 12 & 0 & 1 & 0 & 13 \\
\hline PTB & Coalizão & 2 & 0 & 0 & 3 & 5 \\
\hline PPB & Apoio & 3 & 0 & 0 & 3 & 6 \\
\hline PPS & Apoio & 2 & 0 & 0 & 2 & 4 \\
\hline Total 1 & ----- & 51 & 0 & 1 & 16 & 68 \\
\hline PSB & Oposição & 0 & 1 & 0 & 1 & 2 \\
\hline PDT & Oposição & 1 & 1 & 0 & 4 & 6 \\
\hline PT & Oposição & 1 & 3 & 0 & 1 & 5 \\
\hline Total 2 & ----- & 2 & 5 & 0 & 6 & 13 \\
\hline Total 1 + 2 & ----- & 53 & 5 & 1 & 22 & 81 \\
\hline
\end{tabular}

Fonte: Elaboração própria, a partir do site do Senado Federal (www.senado.gov.br) e Figueiredo, 2006.

Também no segundo turno, a emenda foi aprovada por larga margem. Os votos "sim" representaram $89,83 \%$ dos presentes em plenário e $65,43 \%$ do total da casa. Assim, se a aprovação em cima dos presentes foi maior do que no primeiro turno em 6,50\%, a margem de segurança mínima para a aprovação foi de apenas 5,43\% (um valor um pouco menor que os da Câmara), o que significa uma redução em relação ao primeiro turno de 8,64\%. A tabela acima também informa que a coalizão e os partidos que a apóiam votaram em uníssono, com 100\% de disciplina, independentemente da região do país. Mesmo assim, dos 68 dos apoiadores do governo, apenas 51 votaram: 75\%. A controvérsia aparece entre os partidos oposicionistas, pois dos seus 13 senadores distribuídos em três partidos, apenas cinco votaram contra a emenda e seis nem estiveram em plenário. 
Tabela 4.12 - Votação em segundo turno do Senado Federal da Emenda Constitucional no. 10 (relativa ao FEF), do ponto de vista das regiões do país.

\begin{tabular}{|l|c|c|c|c|c|c|c|c|c|}
\hline Região/Posição & \multicolumn{4}{|c|}{ Coalizão + Apoio } & \multicolumn{4}{c|}{ Oposição } & \multirow{2}{*}{ Total } \\
\hline Voto & SIM & Não & ABS & AUS & SIM & NÃO & ABS & AUS & Tota \\
\hline Norte & 12 & 0 & 0 & 5 & 0 & 2 & 0 & 2 & 21 \\
\hline Nordeste & 19 & 0 & 1 & 5 & 0 & 1 & 0 & 1 & 27 \\
\hline Centro-Oeste & 8 & 0 & 0 & 3 & 0 & 1 & 0 & 0 & 12 \\
\hline Sudeste & 6 & 0 & 0 & 2 & 0 & 1 & 0 & 3 & 12 \\
\hline Sul & 6 & 0 & 0 & 1 & 2 & 0 & 0 & 0 & 9 \\
\hline Total & 51 & 0 & 1 & 16 & 2 & 5 & 0 & 6 & 81 \\
\hline
\end{tabular}

Fonte: Elaboração própria, a partir do site do Senado Federal (www.senado.gov.br) e Figueiredo, 2006.

Constata-se novamente que houve total cooperação dos senadores pertencentes às regiões mais pobres e sobre-representadas do país. Dos 60 senadores do Norte, Nordeste e Centro-Oeste, 39 da situação votaram "sim" e os quatro da oposição votaram "não". Houve, é verdade, uma ausência significativa de 16 senadores entre as três regiões. Mesmo assim o índice de adesão à proposta do governo é de $88,64 \%$ dos presentes e $65 \%$ do total das três regiões. Também seguindo a tendência do primeiro turno, os cinco votos contrários vieram da oposição, além de mais seis deles estarem ausentes no plenário. Se não expressaram seu voto, com sua ausência deixaram de acrescentar mais votos para o governo. Dizendo de outro modo, se são precisos 33 votos destas três regiões para ocorrer o veto, faltou 17 votos para que isso pudesse ter acontecido.

Em resumo, após a tramitação nas duas comissões da Câmara, por três vezes (uma na CCJC e duas na CE), nos dois turnos de votação e a votação também de 11 DVS, a proposta é enviada ao Senado, passa por uma CCJ e vai para duas votações em plenário, quando finalmente é aprovada e promulgada. Pois toda esta tramitação, que envolveu oito possibilidades de veto final, terminou por aprovar a renovação do FSE sem a proposta inicial de quatro anos, pois ficou em um ano e meio e foi aprovada a desvinculação prévia ao que seria repartido com os estados e municípios. E estes últimos obtiveram um pequeno ganho em relação ao FSE. No contexto geral, o saldo foi positivo para a União, desfavorável aos estados e com uma redução de perda para os municípios. Assim também conclui Arretche, quando afirma que "ainda que o Executivo federal tenha feito concessões em sua 
estratégia de compensar os municípios, o saldo líquido é amplamente favorável à União." (Idem, 2007:9).

\section{Fundo de Estabilização Fiscal 2}

A terceira renovação do FSE foi proposta pelo poder Executivo, que deu entrada novamente na Câmara dos Deputados em 6 de março de 1997, faltando três meses para expirar a vigência do FEF1. Contudo, as negociações estenderam-se até novembro do mesmo ano, num total de oito meses. Na Câmara tramitou por cinco meses e depois foi para o Senado onde levou três meses para ser promulgada como a emenda constitucional número 17. Assim como nos dois fundos anteriores, os $20 \%$ de retenção de repasses constitucionais para os estados e municípios foi mantido para o governo federal, agora por mais dois anos, entre 1 de julho de 1997 e 31 de dezembro de 1999.

Assim como na renovação anterior, nesta os municípios conseguem novas compensações, diminuindo mais um pouco suas perdas. $\mathrm{O}$ artigo terceiro estabelece que a União ressarcirá os municípios em valores anuais crescentes de $1,56 \%$ a 2,5\% da arrecadação do Imposto de Renda. A íntegra do conteúdo é esta:

“Art. 3”: A União repassará aos Municípios, do produto da arrecadação do Imposto sobre a Renda e Proventos de Qualquer Natureza, tal como considerado na constituição dos fundos de que trata o art. 159, I, da Constituição, excluída a parcela referida no art. 72, I, do Ato das Disposições Constitucionais Transitórias, os seguintes percentuais:

“ I - um inteiro e cinqüenta e seis centésimos por cento, no período de $1^{\circ}$ de julho de 1997 a 31 de dezembro de 1997;

"II - um inteiro e oitocentos e setenta e cinco milésimos por cento, no período de $1^{\circ}$ de janeiro de 1998 a 31 de dezembro de 1998;

"III - dois inteiros e cinco décimos por cento, no período de $1^{\circ}$ de janeiro de 1999 a 31 de dezembro de 1999." (Brasil, Senado Federal, 2007c).

Na Câmara dos Deputados, a PEC recebeu o número de 449/1997. Foi enviada para a CCJC, dando início à tramitação em 17 de março e formada com a relatoria do deputado José Luiz Clerot (PMDB-PB). A proposta é aprovada em 9 de abril, com votos em contrário de alguns deputados da coalizão, como o PFL-MG, PMDB-GO, PSDB-AM, e de deputados da oposição, como PT, PDT, 
PC do B e PSB, situados em sua maioria no Sul e no Sudeste. Em 7 de maio ela passa a tramitar na $\mathrm{CE}$, tendo agora como relatora a deputada Yeda Crusius (PSDB-RS). Chegou-se a propor 15 emendas para modificar o texto, mas todas foram rejeitadas pela retatora o que, corroborando Arretche (2007), sinaliza uma não disposição da representante do governo em negociar para modificar a proposta. Desta forma ela é novamente aprovada, com votos contrários de deputados do PT, PC do B e PDT.

É encaminhada ao plenário para discussão e votação em primeiro turno, de 10 a 17 de julho. Além da votação principal, são votados sete DVS e duas emendas aglutinativas solicitadas por deputados de partidos oposicionistas - PT e PDT -, todas derrotadas pelo governo. Houve, portanto, um total de dez votações. Assim como no primeiro turno, o objetivo destas votações de trechos específicos a serem incluídos ou modificados no texto principal, objetivavam causar desgaste ao governo, que a cada votação tinha de mobilizar sua bancada para evitar a formação de uma maioria que aprovasse um DVS. ${ }^{6}$

Em torno da votação em primeiro turno - em texto consolidado pela relatora Yeda Crusius houve um acalorado debate sobre a redução de perdas para os municípios, já que a isenção total havia sido derrotada antes. Em vista disso, os municípios lograram as modificações estabelecidas no texto final da emenda aprovada, cujo conteúdo foi exposto linhas acima. Arretche (2007) afirma que o PMDB - partido integrante da coalizão -, alinhou-se com a oposição, com a justificativa de que a aprovação do fundo prejudicaria suas bases eleitorais. Mudou sua posição, depois que a liderança do PSDB fez um acordo com o presidente Fernando Henrique Cardoso, pelo qual seriam incorporadas ao texto da PEC as medidas de ressarcimento aos municípios, pela repartição de parcela de arrecadação do Imposto de Renda. Desta forma, o PMDB volta a apoiar o FEF e a proposta é aprovada, com o seguinte resultado: Sim 362; Não 129; Abs. 1 e Total de $492 .{ }^{69}$ Traduzindo em termos percentuais, temos $73,58 \%$ de $\operatorname{Sim}(70,57 \%$ para o total de 513 deputados); $26,22 \%$ de Não $(25,15 \%)$ e comparecimento de $95,91 \%$ do total. Com isso, a PEC foi aprovada em primeiro turno com uma folga de $10,57 \%$ sobre o total da casa.

\footnotetext{
${ }^{68}$ Vale uma observação, contudo, sobre o segundo DVS, proposto pelo deputado Humberto Costa (PT-PE). Propunha que os municípios tivessem total isenção do FEF. Ou seja, a retenção dos tributos ficaria apenas com os estados. O placar desta votação foi Sim 143 (oposição); Não 339 (governo); Abs. 5 e Total de 487.

${ }^{69}$ Votaram 91 deputados do PMDB e 75 votaram "sim" (82,42\%) e 16 votaram "não" (17,58\%). Dissidências da base estadual aconteceram com um voto contra nos estados do Amazonas, Paraíba, Alagoas, Bahia, Espírito Santo, Rio de Janeiro (empate, pois o outro votou a favor), São Paulo e Santa Catarina. Com dois votos contra, os estados do Ceará, Paraná e Rio Grande do Sul. E com três votos contrários (de um total de oito), o estado de Minas Gerais.
} 
O texto aprovado foi enviado para a $\mathrm{CE}$ a fim de ser redigido para a votação em segundo turno, que acontece no dia 13 de agosto. Além da votação principal, são votados também dois DVS, apresentados pelo PC do B de Minas Gerais e derrotados. Referiam-se a detalhes do texto principal, sem importância substantiva. Desta forma, o placar da votação em segundo turno é: Sim 342; Não 121; Abs. 4 e Total de 467. Em termos percentuais, representa 73,23\% de Sim (66,67\%); 23,59\% de Não e $91,03 \%$ do total. A PEC é aprovada em segundo turno na Câmara com uma margem de $6,67 \%$ sobre o mínimo exigido.

A proposta é enviada ao Senado (e recebe o número 25/1997) em 14 de agosto. Segue no dia seguinte para a Comissão de Constituição e Justiça (CCJ). A proposta - que tem como relator Renan Calheiros (PMDB-AL) -, é aprovada no dia 7 de outubro, com um acréscimo de uma "emenda número 1 de redação" proposta pelo relator. ${ }^{70}$ Recebe um voto contrário de Epitácio Cafeteira (PPB-MA) e pedidos de dois DVS por José Eduado Dutra (PT-SE), rejeitados.

No plenário ocorre duas votações no primeiro turno no dia 5 de novembro. A tabela abaixo resume o resultado da votação principal.

Tabela 4.13 - Votação em primeiro turno do Senado Federal da Emenda Constitucional no. 17 (relativa ao FEF 2) - 5/11/1997.

\begin{tabular}{|l|c|c|c|c|c|c|}
\hline PARTIDO & POSIÇÃo & SIM & NÃO & ABS. & AUSENTE & TOTAL \\
\hline PFL & Coalizão & 19 & 1 & 1 & 0 & 21 \\
\hline PMDB & Coalizão & 17 & 1 & 0 & 2 & 20 \\
\hline PSDB & Coalizão & 12 & 0 & 0 & 1 & 13 \\
\hline PTB & Coalizão & 5 & 0 & 0 & 1 & 6 \\
\hline PPB & Apoio & 4 & 1 & 0 & 1 & 6 \\
\hline PPS & Apoio & 2 & 0 & 0 & 0 & 2 \\
\hline Total 1 & ------ & 59 & 3 & 1 & 5 & 68 \\
\hline PDT & Oposição & 2 & 3 & 0 & 1 & 6 \\
\hline PSB & Oposição & 0 & 2 & 0 & 0 & 2 \\
\hline PT & Oposição & 0 & 4 & 0 & 1 & 5 \\
\hline
\end{tabular}

\footnotetext{
${ }^{70}$ A informação sobre o conteúdo desta "emenda número 1 de redação" não foi encontrada no Diário do Senado Federal e no Diário do Congresso Nacional na internet (www.senado.gov.br).
} 


\begin{tabular}{|l|c|c|c|c|c|c|}
\hline Total 2 & ---- & 2 & 9 & 0 & 2 & 13 \\
\hline Total 1+2 & ----- & 61 & 12 & 1 & 7 & 81 \\
\hline
\end{tabular}

Fonte: Elaboração própria, a partir do site do Senado Federal (www.senado.gov.br) e Figueiredo, 2006.

Os votos favoráveis representaram 82,43\% (75,31\% em relação ao total de 81$)$. Já os contrários ficaram em 16,22\% (14,81\%) e 91,36\% dos senadores estiveram em plenário. Estes números mostram um índice de aprovação maior que a da Câmara, com uma taxa de aprovação além do necessário de 15,31\%. Ao passo que na Câmara, vimos que no primeiro turno foi de $10,57 \%$. Já na coalizão, 59 votaram "sim" e aprovariam sozinhos a emenda. Isso representa 93,65\% dos presentes e $86,76 \%$ do total.

Tabela 4.14 - Votação em primeiro turno do Senado Federal da Emenda Constitucional no. 17 (relativa ao FEF 2), do ponto de vista das regiões do país.

\begin{tabular}{|l|c|c|c|c|c|c|c|c|c|}
\hline Região/Posição & \multicolumn{4}{|c|}{ Coalizão + Apoio } & \multicolumn{4}{c|}{ Oposição } & \multirow{2}{*}{ Total } \\
\hline Voto & SIM & NÃO & ABS & AUS & SIM & NãO & ABS & AUS & Ty \\
\hline Norte & 13 & 1 & 0 & 3 & 1 & 3 & 0 & 0 & 21 \\
\hline Nordeste & 23 & 1 & 1 & 0 & 0 & 2 & 0 & 0 & 27 \\
\hline Centro-Oeste & 11 & 0 & 0 & 0 & 0 & 1 & 0 & 0 & 12 \\
\hline Sudeste & 6 & 0 & 0 & 2 & 0 & 2 & 0 & 2 & 12 \\
\hline Sul & 6 & 1 & 0 & 0 & 1 & 1 & 0 & 0 & 9 \\
\hline Total & 59 & 3 & 1 & 5 & 2 & 9 & 0 & 2 & 81 \\
\hline
\end{tabular}

Fonte: Elaboração própria, a partir do site do Senado Federal (www.senado.gov.br) e Figueiredo, 2006.

Mais uma vez, os senadores das regiões Norte, Nordeste e Centro-Oeste cooperaram amplamente com os objetivos anti-federativos da União. Assim sendo, a esta altura, desconsideremos os senadores da oposição. Ficamos com 53 (88,33\% do total). Este número supera em 20 o necessário para bloquear a aprovação de uma emenda. Mas destes, apenas dois votaram contra, um abstevese e três ausentaram-se. Então, 47 votaram a favor, 88,68\% do total. Já com relação à oposição, dos sete integrantes, seis votaram contra a proposta $(85,71 \%)$. O mesmo padrão é verificado nas duas outras regiões, Sudeste e Sul, no qual, dos 21 representantes, 15 pertencem a partidos que apóiam o governo $(71,43 \%)$. E destes, votaram “sim”, $80 \%$. 
Tabela 4.15 - Votação da Emenda n.o 1 (de Redação), do Senado Federal da Emenda Constitucional no. 17 (relativa ao FEF 2) - 5/11/1997.

\begin{tabular}{|l|c|c|c|c|c|c|}
\hline PARTIDO & POSIÇÃO & SIM & NÃO & ABS. & AUSENTE & TOTAL \\
\hline PFL & Coalizão & 19 & 0 & 2 & 0 & 21 \\
\hline PMDB & Coalizão & 18 & 0 & 0 & 2 & 20 \\
\hline PSDB & Coalizão & 12 & 0 & 0 & 1 & 13 \\
\hline PTB & Coalizão & 5 & 0 & 0 & 1 & 6 \\
\hline PPB & Apoio & 4 & 0 & 0 & 2 & 6 \\
\hline PPS & Apoio & 1 & 0 & 0 & 1 & 2 \\
\hline Total 1 & ------ & 59 & 0 & 2 & 7 & 68 \\
\hline PDT & Oposição & 1 & 1 & 2 & 2 & 6 \\
\hline PSB & Oposição & 0 & 0 & 2 & 0 & 2 \\
\hline PT & Oposição & 0 & 1 & 2 & 2 & 5 \\
\hline Total 2 & ----- & 1 & 2 & 6 & 4 & 13 \\
\hline Total 1 + 2 & ----- & 60 & 2 & 8 & 11 & 81 \\
\hline
\end{tabular}

Fonte: Elaboração própria, a partir do site do Senado Federal (www.senado.gov.br) e Figueiredo, 2006.

Vemos que os números são semelhantes aos da votação do primeiro turno, embora a quantidade de votos "não" tenha sido muito menor e o número de ausentes seja maior. De qualquer maneira, o teor que a emenda propunha foi aprovado.

Tabela 4.16 - Votação da Emenda n.o 1 (de Redação), do Senado Federal da Emenda Constitucional no. 17 (relativa ao FEF 2), do ponto de vista das regiões do país.

\begin{tabular}{|l|c|c|c|c|c|c|c|c|c|}
\hline Região/Posição & \multicolumn{4}{|c|}{ Coalizão + Apoio } & \multicolumn{4}{c|}{ Oposição } & \multirow{2}{*}{ Total } \\
\hline Voto & SIM & NÃo & ABS & AUS & SIM & NÃO & ABS & AUS & Total \\
\hline Norte & 14 & 0 & 0 & 4 & 0 & 1 & 1 & 1 & 21 \\
\hline Nordeste & 21 & 0 & 2 & 2 & 0 & 0 & 2 & 0 & 27 \\
\hline Centro-Oeste & 11 & 0 & 0 & 0 & 0 & 0 & 1 & 0 & 12 \\
\hline Sudeste & 6 & 0 & 0 & 2 & 0 & 0 & 2 & 2 & 12 \\
\hline
\end{tabular}




\begin{tabular}{|l|c|c|c|c|c|c|c|c|c|}
\hline Sul & 7 & 0 & 0 & 0 & 1 & 1 & 0 & 0 & 9 \\
\hline Total & 59 & 0 & 2 & 8 & 1 & 2 & 6 & 3 & 81 \\
\hline
\end{tabular}

Fonte: Elaboração própria, a partir do site do Senado Federal (www.senado.gov.br) e Figueiredo, 2006.

A análise da votação desta emenda de acréscimo com relação ao comportamento das regiões, também não apresenta novidade em relação às anteriores. O que pode ser especulado neste caso é que uma defesa dos interesses federativos e/ou regionais não estivesse em pauta (ou não fosse decisiva), já que esta votação era apenas um acréscimo à emenda de primeiro turno já aprovada. ${ }^{71}$

Após estas duas aprovações, a PEC finalmente chega ao segundo turno. A votação aconteceu no dia 19 de novembro.

Tabela 4.17 - Votação em segundo turno do Senado Federal da Emenda Constitucional no. 17 (relativa ao FEF 2) - 19/11/1997.

\begin{tabular}{|l|c|c|c|c|c|c|}
\hline PARTIDO & POSIÇÃO & SIM & NÃO & ABS. & AUSENTE & TOTAL \\
\hline PFL & Coalizão & 17 & 1 & 1 & 3 & 22 \\
\hline PMDB & Coalizão & 15 & 2 & 0 & 3 & 20 \\
\hline PSDB & Coalizão & 10 & 0 & 0 & 3 & 13 \\
\hline PTB & Coalizão & 5 & 0 & 0 & 0 & 5 \\
\hline PPB & Apoio & 3 & 2 & 0 & 1 & 6 \\
\hline PPS & Apoio & 2 & 0 & 0 & 0 & 2 \\
\hline Total 1 & ----- & 52 & 5 & 1 & 10 & 68 \\
\hline PDT & Oposição & 2 & 4 & 0 & 0 & 6 \\
\hline PSB & Oposição & 0 & 2 & 0 & 0 & 2 \\
\hline PT & Oposição & 0 & 4 & 0 & 1 & 5 \\
\hline Total 2 & ----- & 2 & 10 & 0 & 1 & 13 \\
\hline Total 1 + 2 & ----- & 54 & 15 & 1 & 11 & 81 \\
\hline
\end{tabular}

\footnotetext{
${ }^{71}$ A votação desta emenda no.1 chama a atenção, pois foi a única a quebrar o padrão das duas votações nominais mínimas verificadas no Senado nas emendas analisadas. O que torna difícil a apresentação de DVS no Senado - ao contrário da Câmara - é que, de acordo com o seu Regimento Interno, é necessário o apoio da maioria absoluta (41) para ser considerado pelo plenário.
} 
Fonte: Elaboração própria, a partir do site do Senado Federal (www.senado.gov.br) e Figueiredo, 2006.

Nesta votação a emenda foi aprovada em definitivo, mas por uma margem pouco confortável, pois ficou apenas cinco votos do mínimo necessário. Contribuiu para isso o número relativamente alto de "não" e também os de ausentes. Dos 81 senadores, estiveram em plenário 70 $(86,42 \%)$. Destes, 54 votaram "sim" (76,06\% dos presentes e 66,67\% do total). Os votos contrários foram 15 (21,43\% dos presentes e 18,52\% do total). Se somarmos com os ausentes, temos 26 votos, o que representa $32,10 \%$ do total da casa. Portanto, a taxa de aprovação além do necessário foi de $6,67 \%$. Pois este percentual é o mesmo que foi obtido na votação em segundo turno na Câmara. Na comparação entre uma casa e outra que estamos realizando, é a primeira vez que há uma igualdade de controvérsia entre as duas casas. Entre os participantes da coalizão, 52 deles votaram "sim" dos 58 presentes $(89,86 \%)$ e 68 do total $(76,47 \%)$. Mesmo assim, cinco votaram contra e dez se ausentaram: $22,06 \%$ do total.

Tabela 4.18 - Votação em segundo turno do Senado Federal da Emenda Constitucional no. 17 (relativa ao FEF 2), do ponto de vista das regiões do país.

\begin{tabular}{|c|c|c|c|c|c|c|c|c|c|}
\hline Região/Posição & \multicolumn{4}{|c|}{ Coalizão + Apoio } & \multicolumn{4}{|c|}{ Oposição } & \multirow[b]{2}{*}{ Total } \\
\hline Voto & SIM & NÃO & ABS & AUS & SIM & NÃO & ABS & AUS & \\
\hline Norte & 12 & 1 & 0 & 4 & 1 & 2 & 0 & 1 & 21 \\
\hline Nordeste & 19 & 2 & 1 & 3 & 0 & 2 & 0 & 0 & 27 \\
\hline Centro-Oeste & 8 & 1 & 0 & 2 & 0 & 1 & 0 & 0 & 12 \\
\hline Sudeste & 7 & 0 & 0 & 1 & 0 & 4 & 0 & 0 & 12 \\
\hline Sul & 6 & 1 & 0 & 0 & 1 & 1 & 0 & 0 & 9 \\
\hline Total & 52 & 5 & 1 & 10 & 2 & 10 & 0 & 1 & 81 \\
\hline
\end{tabular}

Fonte: Elaboração própria, a partir do site do Senado Federal (www.senado.gov.br) e Figueiredo, 2006.

Já que o número de votos que aprovou a emenda foi próximo do mínimo, torna-se oportuna uma análise dos números com relação aos votos distribuídos entre as regiões. Dos 60 senadores das regiões Norte, Nordeste e Centro-Oeste, 40 votaram “sim”, o que representa 66,67\% em relação ao total. Assim, 20 senadores destas regiões não contribuíram para a aprovação da emenda, um número que se revela relativamente expressivo, embora siga o padrão das outras votações até aqui. Isso significa que faltou o voto contrário de 13 senadores para que a emenda fosse rejeitada. Todavia, há 53 
deles que apóiam o governo. Deste total, votaram a favor, 39 (73,58\% do total). Já entre as regiões Sudeste e Sul, dos seus 21 representantes, 14 votaram pela aprovação (66,67\% do total). E entre os 15 da situação, 13 confirmaram as expectativas, o que perfaz $86,67 \%$ do total. $\mathrm{O}$ apoio dos senadores das regiões Sudeste e Sul foi igual aos das regiões Norte, Nordeste e Centro-Oeste em relação ao total. Mas com relação àqueles que apoiavam o governo, os das regiões Sul e Sudeste tiveram um percentual de apoio maior, com uma diferença de 13,09\%.

Depois desta análise das votações nas duas casas e em especial no Senado, o que podemos acrescentar é que o FEF em suas duas versões procurou poupar em parte os Fundos de Participação, apesar de reter uma parcela que a eles seria destinada. Segundo relatório do Ministério do Planejamento (2003), "garantia-se, em primeiro lugar, os recursos do FPE, FPM, dos Fundos de Desenvolvimento e os $10 \%$ do IPI - Exportação, para depois se separar os $20 \%$ para o FEF. No entanto, algumas parcelas do Imposto de Renda, como o produto da arrecadação do imposto sobre renda e proventos de qualquer natureza, incidentes na fonte sobre pagamentos efetuados, a qualquer título, pela União, inclusive suas autarquias e fundações e até 5,6\% do produto da arrecadação do Imposto de Renda, ia diretamente para o FEF antes de se proceder o cálculo dos repasses previstos no artigo 159 da Constituição aos demais entes da federação.” (Brasil, Ministério do Planejamento, 2003:15).

Desta maneira, entre 1996 e 1999 - quando vigorou as emendas 10 e 17 (ambas do FEF) estima-se que o ganho efetivo para o governo federal foi de cerca de $\mathrm{R} \$ 7$ bilhões ao ano. Deste valor, por volta de $\mathrm{R} \$ 2,7$ bilhões ao ano refere-se ao ganho relativo à retenção de recursos originalmente destinados aos governos subnacionais, devido principalmente às transferências dos fundos de participação. Os R \$ 4,3 bilhões ao ano restantes, por sua vez, dizem respeito ao efeito de desvinculação líquido, desconsiderando as receitas alocadas ao FEF que já eram livres antes da sua existência. (Idem, 2003:16). ${ }^{72}$

\section{Desvinculação das Receitas da União}

Com a aproximação do término da vigência da emenda 17 o governo federal, mais uma vez, deu início a uma proposta de emenda à Constituição para a terceira renovação do FSE original. Desta vez renomeada como Desvinculação das Receitas da União (DRU), iniciou sua tramitação na

\footnotetext{
${ }^{72}$ Este efeito de desvinculação torna-se importante quando confrontado com o volume de recursos livres para programação, nos orçamentos de 1996 a 1999. Pois nesses exercícios, a soma de recursos atingiu pouco mais de R 50 bilhões por ano, sendo a desvinculação efetiva responsável por 8,6\% deste valor, segundo o mesmo texto do Ministério do Planejamento.
} 
Câmara dos Deputados em 14 setembro de 1999, onde permaneceu por quatro meses (descontado o período de recesso entre o fim de um ano e começo de outro) até o fim de janeiro de 2000, quando foi enviada ao Senado que, depois de mais dois meses, finalmente a promulgou em março do mesmo ano.

A DRU é uma mudança significativa em relação ao fundo anterior. Isso porque não há mais a retenção de parte dos tributos que seriam originalmente pertencentes aos estados e municípios. Os $20 \%$ para efeito de desvinculação do programado no orçamento é realizado sem a dedução da base de cálculo das transferências constitucionais. De acordo com Arretche, esta mudança tem por causa os interesses eleitorais do governo federal - já de olho na sucessão de 2002 -, o que evitaria o desgaste político da negociação verificada em especial na rodada anterior. De outra parte, pode também ser interpretado do ponto de vista dos estados e municípios, que reverteram uma condição que lhes vinha sendo desfavorável. ${ }^{73}$ Originalmente o governo propôs como prazo de vigência o fim de 2007, mas as negociações a reduziram para 31 de dezembro de 2003.

Vale a pena reproduzir o texto integral da emenda:

“Art. $1^{\circ}$ É incluído o art. 76 ao Ato das Disposições Constitucionais Transitórias, com a seguinte redação:

“Art. 76. É desvinculado de órgão, fundo ou despesa, no período de 2000 a 2003, vinte por cento da arrecadação de impostos e contribuições sociais da União, já instituídos ou que vierem a ser criados no referido período, seus adicionais e respectivos acréscimos legais.

“\$ $1^{\circ} \mathrm{O}$ disposto no caput deste artigo não reduzirá a base de cálculo das transferências a Estados, Distrito Federal e Municípios $^{74}$ na forma dos arts. 153, § 5; 157, I; 158, I e II; e 159, I, "a" e "b", e II, da Constituição, bem como a base de cálculo das aplicações em programas de financiamento ao setor produtivo das regiões Norte, Nordeste e Centro-Oeste a que se refere o art. 159, I, "c", da Constituição.

\footnotetext{
${ }^{73}$ De acordo com Samuels (2003b:188), isto garantiu um aumento (ou uma não perda, se colocarmos em outros termos), de R \$ 3,2 bilhões para os governos subnacionais.

${ }^{74} \mathrm{O}$ grifo é meu.
} 
“\$ $2^{\circ}$ Excetua-se da desvinculação de que trata o caput deste artigo a arrecadação da contribuição social do salário-educação a que se refere o art. $212, \S 5^{\circ}$, da Constituição."75 (Brasil, Senado Federal, 2007c).

Já que a desvinculação deixou de retirar os tributos dos governos subnacionais, em si mesma, a questão pode ser considerada como de cunho não-federativo. Afinal os entes não estão perdendo as receitas, como ocorreu nas três oportunidades anteriores. Mesmo assim, a análise das tramitações e principalmente das votações na Câmara e no Senado será realizada com o objetivo prático de verificarmos se, por causa deste motivo, a adesão dos deputados e senadores será maior (ou ao menos motivada por outras razões). Por comparação, talvez seja possível demonstrar de uma outra maneira se os interesses federativos realmente foram um fator importante, não na DRU, mas nas outras três versões do fundo.

A PEC deu entrada na Câmara dos Deputados para o início da tramitação, com o número 85/1999. Foi enviada no dia 14 de setembro para a CCJC, sob a relatoria de Eujácio Simões (PLBA). A proposta tem a aprovação no dia 29 do mesmo mês, com 13 votos em contrário, de partidos oposicionistas - PT, PSB e PDT - e da coalizão e seus apoiadores: PMDB, PP, PTB e PL. Aparentemente não havia homogeneidade de posições entre os deputados de uma parte a outra.

Em 13 de outubro ela chega à Comissão Especial, tendo como novo relator Pinheiro Landim (PMDB-CE). Ao contrário da divisão entre governo e oposição sobre os votos em contrário na CCJC, nesta comissão a dissidência é quase toda da oposição, com cinco votos "não" do PT, e do PC do B e um do PMDB. Há ainda a rejeição de sete emendas apresentadas ao texto original. O relator dá o seu aval e envia para o plenário.

A proposta é discutida e votada em primeiro turno entre os dias 24 de novembro e 12 de janeiro de 2000, com nove votações: sete DVS, uma emenda aglutinativa e a votação da emenda. A maior parte dos DVS votados são originários daqueles rejeitados na CE. Foram todos propostos pela oposição - PDT, PT, PSB e PC do B - e derrotados em plenário. Em linhas gerais, estes DVS referiam-se à retirada de alguns trechos da PEC tal como consolidada pelo relator da CE. A intenção dos partidos de oposição não é tanto conseguir vitória - mesmo porque são minoria -, mas dificultar a tarefa do governo, por meio de seguidas votações, provocando desgaste e visibilidade na opi-

\footnotetext{
${ }^{75}$ O conteúdo deste artigo é: "O ensino fundamental público terá como fonte adicional de financiamento a contribuição social do salário-educação, recolhida pelas empresas, na forma da lei.” (Brasil, Constituição Federal, 2007a).
} 
nião pública sobre os seus objetivos, agora relacionados ao corte de valores antes destinados à educação, mais precisamente ao salário-educação do ensino fundamental.

Na votação principal o governo obtém vitória em plenário: Sim 343; Não 137 e Total de 480 presentes. Em termos percentuais, este placar significa que $71,46 \%$ dos presentes a aprovaram (66,86\% do total). Ou seja, a PEC foi aprovada com uma margem de 6,86\%, um percentual menor do que o verificado no primeiro turno do FEF 1 (7,25\%) e do FEF 2 (10,57\%).

A discussão e votação em segundo turno aconteceu no dia 26 de janeiro. Foram apresentados 6 DVS, além da votação principal. Os destaques, mais uma vez, couberam ao PT e ao PSB, além de um do PPS, partido que embora não faça parte da coalizão, apóia o governo nas votações. Quatro destas votações em separado obtiveram aprovação, contando para isso com os votos dos partidos da coalizão. É que não havia controvérsia sobre o conteúdo, mas apenas a melhor compreensão ou especificação do texto em seu conjunto, como o acréscimo de uma ou outra palavra. Para a votação em segundo turno, o resultado foi: Sim 346; Não 133 e Total de 479. Isso representa que $72,23 \%$ dos presentes a aprovaram $(67,45 \%$ do total). Uma folga de $7,45 \%$ para a aprovação da PEC, o que é um valor um pouco maior do que o do primeiro turno e em nível semelhante às da votação em segundo turno do FEF 1 (7,84\%) e maior que o do FEF $2(5,43 \%)$.

Com estas comparações sobre as margens de aprovação das três emendas evidencia-se que não houve grande diferença entre os percentuais. Talvez uma indicação de que a ausência da discussão sobre a repartição de tributos na DRU, mas que estava presente nas duas versões do FEF, não influiu sobre os resultados. Embora fosse uma questão federativa das mais importantes, talvez ela não tenha sido discutida em seus próprios termos ou não tanto como em relação a uma divisão de interesses partidários e ideológicos, cristalizados em governo de um lado e oposição de outro. A semelhança dos números dão conta disso, porque o tamanho dos parlamentares a apoiarem o governo e a ele se oporem não mudou de forma significativa neste período. Vejamos se esta tendência mantém-se nas duas votações da DRU no Senado.

A PEC, agora rebatizada com o número 4/2000, dá entrada no Senado em 27 de janeiro. É encaminhada para a CCJ no dia 2 de fevereiro, com a relatoria de Lúcio Alcântara (PSDB-CE). Recebe a aprovação no dia 9 de fevereiro, com rejeição de uma emenda de Antônio Carlos Valadares (PSB-SE) e votos contrários de senadores do PT, PSB, PDT, PPS e PTB. 
Entra em plenário no dia 10 de fevereiro e a votação em primeiro turno é feita no dia 23 de fevereiro com o seguinte resultado:

Tabela 4.19 - Votação em primeiro turno do Senado Federal da Emenda Constitucional no. 27 (relativa a DRU) - 23/2/2000.

\begin{tabular}{|l|c|c|c|c|c|c|}
\hline PARTIDO & POSIÇÃo & SIM & NÃO & ABS. & AUSENTE & TOTAL \\
\hline PFL & Coalizão & 15 & 0 & 1 & 1 & 17 \\
\hline PL & Coalizão & 1 & 0 & 0 & 0 & 1 \\
\hline PMDB & Coalizão & 22 & 0 & 0 & 2 & 24 \\
\hline PSDB & Coalizão & 14 & 0 & 0 & 2 & 16 \\
\hline PTB & Coalizão & 3 & 1 & 0 & 1 & 5 \\
\hline PPB & Coalizão & 1 & 0 & 0 & 0 & 1 \\
\hline PPS & Apoio & 1 & 0 & 0 & 1 & 2 \\
\hline Total 1 & ------ & 57 & 1 & 1 & 7 & 66 \\
\hline PDT & Oposição & 1 & 3 & 0 & 0 & 4 \\
\hline PSB & Oposição & 1 & 2 & 0 & 0 & 3 \\
\hline PT & Oposição & 0 & 7 & 0 & 1 & 8 \\
\hline Total 2 & ----- & 2 & 12 & 0 & 1 & 15 \\
\hline Total 1 + 2 & ----- & 59 & 13 & 1 & 8 & 81 \\
\hline
\end{tabular}

Fonte: Elaboração própria, a partir do site do Senado Federal (www.senado.gov.br) e Figueiredo, 2006.

Em primeiro lugar, nota-se que a votação da DRU acontece numa nova legislatura, a $51^{\mathrm{a}}$ (1999-2003). Ocorre um realinhamento dos partidos que apóiam ou são contra o governo e desta maneira, a coalizão aumenta de tamanho, passando de seis partidos para sete - incluindo aqueles que apoiam na prática o governo nas votações. Mas curiosamente, o número de senadores diminui, de 68 para 66, o que revela um crescimento discreto da oposição, de 13 para 15 senadores. Como veremos a seguir estas pequenas alterações entre aliados e opositores não influem no resultado final das emendas, nem em sua aprovação e nem em comparação com as votações da legislatura anterior.

Pois a primeira votação no Senado da emenda que instituiu a DRU foi aprovada por 59 votos, que representam $80,82 \%$ dos presentes e $72,84 \%$ do total, ou seja, $12,84 \%$ a mais que o míni- 
mo. Um valor menor do que o obtido no primeiro turno do Senado para as duas versões do Fundo de Estabilização Fiscal: FEF 1 (14,07\%) e FEF 2 (15,31\%). Já com relação à Câmara, vemos que a taxa de aprovação do Senado é maior nos dois turnos da outra casa: 5,98\% a mais no primeiro turno e 5,39\% no segundo turno. Com relação aos votos contrários registrados na coalizão, vemos que foi de apenas um, além dos sete ausentes. Mesmo assim, ela sozinha aprovaria a emenda com os 57 votos dos seus 65 (96,61\% dos presentes e $86,36 \%$ do total).

Tabela 4.20 - Votação em primeiro turno do Senado Federal da Emenda Constitucional no. 27 (relativa a DRU), do ponto de vista das regiões do país.

\begin{tabular}{|l|c|c|c|c|c|c|c|c|c|}
\hline Região/Posição & \multicolumn{4}{|c|}{ Coalizão + Apoio } & \multicolumn{4}{c|}{ Oposição } & \multirow{2}{*}{ Total } \\
\hline Voto & SIM & NÃO & ABS & AUS & SIM & NÃO & ABS & AUS & Totaly \\
\hline Norte & 13 & 0 & 0 & 2 & 1 & 4 & 0 & 1 & 21 \\
\hline Nordeste & 19 & 1 & 1 & 3 & 0 & 3 & 0 & 0 & 27 \\
\hline Centro-Oeste & 9 & 0 & 0 & 2 & 0 & 1 & 0 & 0 & 12 \\
\hline Sudeste & 9 & 0 & 0 & 0 & 0 & 3 & 0 & 0 & 12 \\
\hline Sul & 7 & 0 & 0 & 0 & 1 & 1 & 0 & 0 & 9 \\
\hline Total & 57 & 1 & 1 & 7 & 2 & 12 & 0 & 1 & 81 \\
\hline
\end{tabular}

Fonte: Elaboração própria, a partir do site do Senado Federal (www.senado.gov.br) e Figueiredo, 2006.

Nesta votação, em que as transferências deixaram de entrar no cálculo da desvinculação das receitas, seria de se esperar uma votação mais tranqüila a favor da aprovação, já que os interesses federativos não estariam sendo prejudicados. Entre as três regiões sobre-representadas, Norte, Nordeste e Centro-Oeste, o que vemos é que dos 60 senadores destas regiões, 42 votaram "sim", $70 \%$ do total, incluindo os ausentes. É curioso que a maioria dos ausentes encontram-se nos partidos governistas e na oposição a maioria dos contrários declarou voto em plenário. O total destes que não apoiaram foi de $16,26,67 \%$ do total. Separando entre os que apóiam ou não a emenda, $82 \%$ votaram "sim" na coalizão e $90 \%$ estiveram contra na oposição. A clivagem continua ocorrendo entre governo versus oposição. E veja que na região Sudeste isto ocorre totalmente: todos os nove da situação votaram a favor e os três da oposição votaram contra.

O segundo turno ocorre entre os dias $1^{\circ}$ a 15 de março, com o seguinte resultado: 
Tabela 4.21 - Votação em segundo turno do Senado Federal da Emenda Constitucional no. 27 (relativa a DRU) - 15/3/2000.

\begin{tabular}{|l|c|c|c|c|c|c|}
\hline PARTIDO & POSIÇÃO & SIM & NÃO & ABS. & AUSENTE & TOTAL \\
\hline PFL & Coalizão & 14 & 0 & 2 & 1 & 17 \\
\hline PL & Coalizão & 1 & 0 & 0 & 0 & 1 \\
\hline PMDB & Coalizão & 21 & 2 & 0 & 1 & 24 \\
\hline PSDB & Coalizão & 14 & 0 & 0 & 2 & 16 \\
\hline PTB & Coalizão & 3 & 1 & 0 & 1 & 5 \\
\hline PPB & Coalizão & 1 & 0 & 0 & 0 & 1 \\
\hline PPS & Apoio & 1 & 1 & 0 & 0 & 2 \\
\hline Total 1 & ------ & 55 & 4 & 2 & 5 & 66 \\
\hline PDT & Oposição & 1 & 3 & 0 & 0 & 4 \\
\hline PSB & Oposição & 1 & 2 & 0 & 0 & 3 \\
\hline PT & Oposição & 0 & 7 & 0 & 1 & 8 \\
\hline Total 2 & ----- & 2 & 12 & 0 & 1 & 15 \\
\hline Total 1 + 2 & ----- & 57 & 16 & 2 & 6 & 81 \\
\hline
\end{tabular}

Fonte: Elaboração própria, a partir do site do Senado Federal (www.senado.gov.br) e Figueiredo, 2006.

Nesta última votação, a emenda número 27 foi aprovada por $76 \%$ dos presentes e $70,37 \%$ em relação ao total, ou seja, 10,37\% além do mínimo necessário, menor em 2,47\% em relação ao primeiro turno. Em comparação com os segundos turnos das duas emendas anteriores, temos no FEF $1(5,43 \%)$ e no FEF $2(6,67 \%)$. Ou seja, a DRU foi aprovada em definitivo com uma margem um pouco maior. Em relação à Câmara, vemos que este último percentual é maior do que os dos dois turnos desta casa, seguindo a tendência já vista no primeiro turno. Na coalizão, dos 66 senadores 61 votaram e destes 55 a aprovaram, o que significa 83,33\% do total. Entre os oposicionistas, dos 15 , só um se ausentou, e entre os presentes, 12 votaram "não", um índice de $80 \%$ em relação ao total. Todos estes números mostram que a votação desta PEC segue a tendência das outras aprovadas: ampla cooperação do Senado, independentemente de a causa em questão ser de maior ou menor impacto federativo. 
Tabela 4.22 - Votação em segundo turno do Senado Federal da Emenda Constitucional no. 27 (relativa a DRU), do ponto de vista das regiões do país.

\begin{tabular}{|c|c|c|c|c|c|c|c|c|c|}
\hline Região/Posição & \multicolumn{4}{|c|}{ Coalizão + Apoio } & \multicolumn{4}{|c|}{ Oposição } & \multirow[b]{2}{*}{ Total } \\
\hline Voto & SIM & NÃO & ABS & AUS & SIM & NÃO & ABS & AUS & \\
\hline Norte & 13 & 1 & 1 & 2 & 1 & 4 & 0 & 0 & 21 \\
\hline Nordeste & 18 & 2 & 1 & 2 & 0 & 4 & 0 & 0 & 27 \\
\hline Centro-Oeste & 10 & 0 & 0 & 0 & 0 & 1 & 0 & 0 & 12 \\
\hline Sudeste & 8 & 1 & 0 & 1 & 0 & 2 & 0 & 0 & 12 \\
\hline Sul & 6 & 0 & 0 & 0 & 1 & 1 & 0 & 1 & 9 \\
\hline Total & 55 & 4 & 2 & 5 & 2 & 12 & 0 & 1 & 81 \\
\hline
\end{tabular}

Fonte: Elaboração própria, a partir do site do Senado Federal (www.senado.gov.br) e Figueiredo, 2006.

A interpretação dos votos através das regiões nos mostra que dos 60 votos das regiões Norte, Nordeste e Centro-Oeste 42 votaram a favor, o mesmo número da votação do primeiro turno, o que perfaz $70 \%$ do total, incluindo os ausentes. E de novo aqui os ausentes pertencem aos partidos da coalizão. Ou uma forma discreta de mostrar discordância ou certo relaxamento, já que sabem que a vitória está garantida. É provável que a segunda hipótese seja a mais correta. Já nas regiões Sudeste e Sul, a tendência do primeiro turno manteve-se com alterações insignificantes, pois no Sudeste, oito ao invés dos nove do primeiro turno, votaram "sim" e no Sul, seis ao invés dos sete que no primeiro turno a apoiaram. Assim como em todas as outras votações comentadas, os discordantes não estão situados entre as regiões que poderiam ser as mais prejudicadas, mas entre os partidos de oposição. Esta última votação é mais um exemplo, pois dos 16 votos "não", 12 deles foram da oposição $(75 \%)$.

Com o processo de negociação das dívidas dos estados e a aprovação renovada de quatro fundos fiscais o governo federal aumentou seu poder em relação aos governos subnacionais. De um ponto de vista dos estados talvez possamos dizer que o conceito de federalismo predatório inverteuse a favor da União. Mas será mesmo que esta passou a predar os estados como estes antes faziam com relação à União? Depende do que se entende pela idéia de prejuízo entre os estados de um lado e a União de outro. No conjunto o fato é que a inflação e a desordem fiscal foram controladas, o que é uma vantagem para todos os entes federativos, participantes de um mesmo sistema institucional, tanto em termos econômicos, como políticos. 
Em todo caso, a mudança do pêndulo de força a favor da União, acontece primeiro do ponto de vista fiscal, pois de um lado tornou-se a única credora dos estados, recebendo destes recursos para o saldo da dívida e sob a ameaça de sansões caso não honrassem seus compromissos. E de outro, reteve $20 \%$ do que seria repassado aos estados e municípios através dos fundos de participação, no FSE, FEF 1 e FEF 2. O já citado relatório do Ministério do Planejamento (2003) informa que tendo em vista que os percentuais dos Fundos de Participação não variaram desde a promulgação da Constituição em 1988, a participação das transferências no total das receitas da União tem se mantido em um patamar homogêneo, em torno de $14 \%$ do total arrecadado. Ainda assim o governo federal melhorou sua condição em relação aos governos subnacionais, não apenas por reter $20 \%$, mas também por conseguir renovar esta retenção por mais vezes. E em segundo lugar, do ponto de vista da restrição da autonomia dos estados e municípios que, perderam recursos e patrimônios (bancos e empresas) e tiveram parte de sua arrecadação destinada ao pagamento dos débitos.

Em contrapartida, o tempo limitado de vigência de cada emenda significa que a União teve de negociar a aprovação original do fundo a cada nova rodada de negociações. Samuels (2003a) defende que "estados e municípios ganhavam novas oportunidades de obter vantagens adicionais em troca do apoio ao programa macroeconômico do governo e, naturalmente, o presidente [tinha] de fazer mais concessões do que se a emenda tivesse sido permanente desde o começo. (Samuels, 2003a:823). Como mostrado nas duas renovações do Fundo de Estabilização Fiscal, os municípios obtiveram pequenos ganhos, perdendo menos de uma renovação para outra. E na terceira renovação, a Desvinculação das Receitas da União, os estados e municípios deixaram de perder os seus recursos dos Fundos de Participação.

Nesse sentido, Arretche (2007) observa que a partir da aprovação da DRU em 2000, é reposto o princípio da Constituição de 1988, de que "as alíquotas de arrecadação do Imposto de Renda e do Imposto sobre Produtos Industrializados (IPI) voltaram a ser integralmente destinadas aos fundos constitucionais." (Arretche, 2007:20). Em outras palavras, na aprovação das duas versões da DRU a segunda em 2003 no governo Lula -, deixaram de estar envolvidas as perdas fiscais às receitas constitucionais dos estados e municípios.

Contudo, a narrativa sobre o processo de ajuste fiscal por parte da União, a partir de 1994, não está limitada à renegociação das dívidas dos estados e à criação e renovação períodica de um fundo fiscal. Passa também por outros mecanismos de arrecadação fiscal e mudança de legislação que tornou o processo mais complexo e, de certa forma, mais positivo para os interesses da União. 
De um lado a criação e/ou ampliação das chamadas contribuições sociais e de outro a criação da Lei de Responsabilidade Fiscal em 2000.

As contribuições sociais tornaram-se ao longo da década de 90 a principal fonte de arrecadação da União. Antes de mais nada, uma disposição contida na Constituição explica este fato, pois elas não precisam ser partilhadas com os estados e municípios, é um tributo exclusivo da União. ${ }^{76}$

As contribuiçõos saltaram de 0,88\% do PIB (em reais) em 1995, primeiro ano do governo Fernando Henrique Cardoso para 10,66\% em 1998, 14,38\% em 2002 (último ano do seu governo) e chegou a 16,09\% em 2006, no fim do primeiro mandato do governo Lula. ${ }^{77} \mathrm{E}$ tal qual as emendas relativas aos fundos, a principal das contribuições - a CPMF - também tem caráter provisório, tanto que passaram por duas renovações, através das emendas constitucionais de número 21 (a primeira do segundo mandato, em março de 1999), e 37 (quase no fim do mandato, em junho de 2002) e tem prazo de vencimento para o fim de 2007. Portanto, as contribuições em geral tornaram-se mais um elemento de reforço fiscal da União em relação aos governos subnacionais, carentes destes tributos.

Em linha de argumentação semelhante à de Rigolon e Giambiagi (1999), Almeida (2005) pondera que o crescimento das contribuições sociais não é uma evidência de recentralização, mas “antes expressão da dificuldade em alterar o padrão da descentralização físcal estabelecido pela Constituição de 1988. O governo federal expandiu as contribuições sociais porque tinha dificuldades em reduzir significativamente em seu benefício, a parcela de receitas tributárias compartilhadas com estados e municípios." (Almeida, 2005:35). É nesse sentido uma demonstração dos limites da estratégia dos fundos fiscais. Pois eles não foram suficientes para garantir ao governo federal uma maior desvinculação de suas receitas, em especial aqueles destinadas aos governos subnacionais.

E este processo de ajuste fiscal e das relações de força entre os entes federativos na atual democracia brasileira também foi ampliado com a criação de uma lei que passou a disciplinar o comportamento fiscal dos entes, a Lei de Responsabilidade Fiscal, aprovada em maio de 2000. Co-

\footnotetext{
${ }^{76}$ As principais contribuições sociais são: Contribuição para o Financiamento da Seguridade Social (COFINS), Contribuição para o Programa de Integração Social e para o Programa de Formação do Patrimônio do Servidor Público (PIS/PASEP), Contribuição Social sobre o Lucro Líquido das Pessoas Jurídicas (CSLL), Contribuição Provisória sobre Movimentação Financeira (CPMF) e Contribuição para o Seguro Social incidente sobre a folha de pagamento (empregado/empregador) e sobre o trabalho autônomo. Há, ainda, a Contribuição de Intervenção no Domínio Econômico (CIDE-Combustíveis), a única que transfere $20 \%$ aos estados e $5 \%$ para os municípios. (Ministério da Fazenda, 2002a e Teixeira, 2005).

77 Estes dados foram calculados a partir de informações contidas na Secretaria do Tesouro Nacional (www.tesouro.gov.br) e Instituto Brasileiro de Geografia e Estatística (www.ibge.gov.br).
} 
mo já abordamos no capítulo anterior, foi aprovada depois que as dívidas com os estados já haviam sido negociadas, e o próprio Plano Real e seu conseqüente ajuste fiscal, entre fundos e contribuições já estava em curso. Ou seja, um novo ambiente já havia sido amadurecido, no sentido de que "a autonomia dos governos subnacionais - especialmente a autonomia para definir despesas e alocar recursos - deveria ser restringida ou controlada. O consenso anterior sobre as virtudes da descentralização, de alguma forma, perdeu força sob a pressão da urgência de ajustar a economia e estabilizar a moeda." (Idem, 2005:35).

\section{Conclusão: ao invés de veto, há cooperação com o governo}

Acompanhamos até aqui uma exaustiva exposição sobre alguns dos principais aspectos das mudanças nas relações políticas e fiscais ocorridas a partir da aprovação do Fundo Social de Emergência. A ênfase principal de análise teve como foco as relações entre os entes da federação, basicamente com interesses divergentes, como a União de um lado e estados e municípios de outro.

Constatamos que o quadro de descentralização fiscal consagrado na Constituição de 1988 foi alterado, com a União recuperando parte de seu poder de tributar, reter recursos que seriam partilhados e controlar parte do comportamento fiscal e administrativo das unidades federativas através, principalmente, do processo de renegociação das dívidas dos estados e dos recursos de gastos condicionados, especialmente em áreas sociais.

As dívidas dos estados com a União não necessitaram de mudanças constitucionais para serem efetivadas, embora tenham acontecido várias negociações no Legislativo federal para a aprovação de condições para a reestruturação das dívidas e em especial a situação dos bancos estaduais. Já a criação de um fundo fiscal necessitou alterações na Constituição. Desta maneira analisamos cada uma delas, o FSE, o FEF 1, o FEF 2 e a DRU, as três últimas durante a vigência do governo Fernando Henrique Cardoso.

Por meio do exame das tramitações entre as duas casas do Congresso Nacional examinamos em especial as votações nominais, tendo como interesse principal os resultados obtidos no Senado Federal.

Desde o princípio estamos problematizando a hipótese de Stepan (1999), de que o Senado brasileiro - dentre outras federações -, tem poderes para vetar eventuais interesses concentrados em 
representantes de uma maioria nacional, pois sobre-representa os interesses de uma minoria do país, que habita as regiões Norte, Nordeste e Centro-Oeste.

A análise das renovações dos fundos fiscais - um tema relevante para os entes federativos por meio da interpretação das votações nominais no Senado procurou mostrar afinal, se, como, em que condições e por quais razões, o Senado pode constranger o demos no Brasil.

Pois se é fato que existe uma ampla situação possível de veto concentrada nestas três regiões, é fato também que não ocorreu nenhuma possibilidade de que isso viesse a acontecer nestas votações. Pode-se alegar que o universo de pesquisa é pequeno, não sendo possível generalizar. Mas em especial estas renovações dos fundos servem de base de como um tema relevante de interesse federativo - e em especial a estas três regiões, pois $85 \%$ dos FPE está a elas destinadas -, é tratado pelos parlamentares federativos, os senadores.

Claro que há também o argumento contra-factual, ou seja, de que poderia existir propostas que não seriam apresentadas porque saberia-se, de antemão, que não seriam aprovadas, devido à composição demos constraining do Senado. Os resultados das votações de casos reais mostram que estes argumentos estiveram distantes da realidade, pois o grau de aprovação das emendas foi alto. Em todo caso, levemos em conta neste momento estas ponderações.

Como este poder de veto poderia de fato entrar em operação em uma votação nominal em plenário? O que os exemplos do processo de refinanciamento das dívidas dos estados e as negociações para as renovações dos fundos fiscais mostraram é que este potencial de veto tem mais possibilidade de ocorrer como um instrumento em uma barganha, uma ameaça que, eventualmente, dadas certas condições políticas, poderia ser posto em prática. ${ }^{78}$ Embora o argumento seja relevante em termos normativos, existe a dificuldade em verificar sua ocorrência concreta, e que sob que custos e conseqüências ele poderia ocorrer.

Isso porque há também a questão da informação prévia que seria levada em consideração pelo proponente de um projeto, digamos o Executivo. Sabendo que um dado projeto teria dificuldades em ser aprovado ou que seria rejeitado, o governo nem chegaria a apresentá-lo. Esta situação poderia ser descrita como de um veto antecipado? Será mesmo? Afinal ele não foi consumado na prática.

\footnotetext{
${ }^{78}$ Vale lembrar a articulação que ocorreu entre os senadores das três regiões sobre-representadas na defesa dos interesses dos bancos de seus estados.
} 
O que podemos afirmar é que o Executivo pode - no máximo - consultar os parlamentares e grupos da sociedade afetados por um dado projeto. E inferir a partir daí se um projeto terá mais ou menos dificuldade em ser aprovado.

Em outro trabalho, Stepan (2002) pergunta: "O que é mais importante: O fato de que a maioria das medidas que o presidente propôs ao Congresso foram realmente aprovadas ou o fato de que muitas das medidas que o presidente gostaria de ver aprovadas nos primeiros cinco anos [sic] da presidência nunca foram apresentadas, porque ele acreditava que jamais seriam aprovadas?" (Stepan, 2002:292).

Para responder com precisão, teríamos de saber que "muitas medidas" eram essas. O autor deveria fornecê-las em bases empíricas para ficarmos no mesmo plano das medidas aprovadas, verificadas empiricamente. Mas tal não é possível, porque elas não foram reais, no sentido de que não foram votadas pelas regras institucionais. Então o que ele oferece são "estudos das propostas políticas escritas antes que a administração Cardoso assumisse o poder, em entrevistas com vários ministros do início da [mesma] administração sobre seus planos (...) que nunca chegaram ao Congresso.” (Idem, 2002:292).

Figueiredo e Limongi (1999) argumentam que no caso brasileiro, o Executivo conta com amplos poderes legislativos para fazer valer seus interesses. E a própria organização interna bastante centralizada nas duas casas do Congresso também facilita seu trabalho. Além disso, "o presidente conta ainda com a vantagem estratégica de apelar diretamente à opinião pública (...) [Desta forma] por que o Executivo deixaria de submeter ao Congresso seus projetos? Não seria mais adequado transferir os custos da rejeição ao Congresso?” (Figueiredo e Limongi, 1999:69).

Em resposta a esta última indagação, é possível ocorrer outras situações em que o Executivo apresente um projeto impopular para ser votado pelo Congresso - por exemplo em um tema de aumento de impostos. Neste caso o custo político seria do Executivo e o ganho (em rejeitar) do Legislativo. Ainda mais se o governo não tem maioria, ou é uma maioria pouco expressiva. Ou ainda seja um governo impopular. Talvez este fosse um caso em que o Executivo pensasse duas vezes antes de enviar o projeto para a apreciação dos parlamentares. Contudo, são argumentos contra-factuais, instigantes, mas na mesma linha de Stepan, intuitivos, o que ajuda pouco na compreensão de situações concretas. 
O que temos de concreto é que ao contrário de outras federações, como por exemplo a da Alemanha, não existe na brasileira regras decisórias específicas para a tramitação de matérias de interesse federativo. ${ }^{79}$ Estas estão imiscuídas com as de outros temas que, não raro, terminam por terem impacto federativo, por causa justamente da estrutura institucional assim estabelecida.

Como afirma Arretche (2007), "a capacidade de veto dos governos territoriais às iniciativas de mudança na estrutura federativa é afetada pelas regras para a aprovação das matérias legislativas. Estas não sustentam a hipótese de que haveria uma multiplicidade de pontos de veto na cadeia de decisões que envolvem questões federativas. As regras de tramitação destas matérias são as mesmas da legislação federal. Nesta, os pontos de veto são basicamente as comissões legislativas e o plenário das Casas. O resultado do trabalho das comissões e das votações em plenário, por sua vez, é afetado pelos recursos de que dispõem o Executivo Federal e os líderes partidários para obter apoio às propostas do Executivo Federal. Uma vez que este obtenha apoio em uma coalizão partidária, restringe-se enormemente os recursos de veto da oposição." (Arretche, 2007:23-24).

E o que constatamos na análise das votações nominais das duas Casas, em especial do Senado, é que a clivagem de interesses é partidária e não federativa (ou regional). Os temas se articulam nos partidos, divididos entre os que apóiam o governo e aqueles que fazem oposição. A maior parte dos votos contrários às emendas analisadas está na oposição. Inclusive, o grau de adesão da casa federativa foi maior do que a da casa do povo nas votações analisadas. Quer dizer: o Senado coopera de forma partidária com os interesses nacionais e - nos casos em questão - anti-federativos do governo federal.

Além disso, observa-se que os votos da oposição estão concentrados de forma majoritária nas regiões Sudeste e Sul. Ou seja, mesmo que os interesses das regiões mais afetadas pelas emendas tenham sido as sobre-representadas, elas votaram com o governo, porque a articulação é partidária e não de defesa dos interesses regionais. Uma eventual maneira de defesa dos interesses regionais destas mesmas regiões, talvez seria mais bem-sucedida se as regiões Sudeste e Sul tivessem

\footnotetext{
${ }^{79} \mathrm{Na}$ Alemanha mais da metade das leis necessita da aprovação do Conselho Federal (o nome dado à câmara alta), isto é, não pode entrar em vigor sem ou contra a vontade da maioria dos seus membros. As leis estão sujeitas à aprovação do conselho quando afetam interesses substanciais dos estados, por exemplo, quando intervêm nas finanças ou nas suas soberanias administrativas. (Jung, 1995; Stepan, 1999).
} 
mais representantes na oposição. E isso porque o incentivo para o apoio ou oposição teriam em vista, principalmente, os interesses alocados nos partidos. ${ }^{80}$

Isso não significa que o tema federativo tenha estado ausente das discussões e considerações por parte dos parlamentares na hora de decidirem seus votos, mas a defesa dos interesses dos estados e municípios foram realizados em sua maior parte pela oposição. Ou seja, se oposição defendese os interesses federativos porque está-se contra o governo. Depois no governo a mesma oposição passa a defender os interesses nacionais. Embora não tenhamos trabalhado com tal situação, ela ocorreu a partir do governo Lula, quando a oposição tornou-se governo e foi autora e defensora de uma emenda constitucional de fundo fiscal, a de número 42 - a primeira renovação da DRU - em dezembro de 2003.

Desta forma, podemos concluir em primeiro lugar que o processo de ajuste fiscal concentrou mais poder para a União e restringiu a autonomia política e administrativa dos estados e municípios, mudando a configuração de forças no interior da federação brasileira. Assim, entre aqueles que argumentam a favor de uma centralização (Kugelmas e Sola, 2000; Mora, 2002; Melo, 2005; Teixeira, 2005; Arretche, 2007) e aqueles que a questionam ou relativizam (Garman, Leite e Marques, 2001; Abrucio e Costa, 1998; Samuels, 2003; Almeida, 2005), coloco-me em uma posição de concordância com o fortalecimento da União.

Em segundo lugar, por meio da análise das tramitações e votações na Câmara e no Senado, constata-se que o principal locus de deliberação dos temas federativos em questão ocorre na Câmara dos Deputados. De saída podemos apontar que uma das causas para isso é que a principal interlocução do poder Executivo é com a Câmara, pois é nela que há um maior potencial de dificuldades para a aprovação dos projetos do governo, especialmente de uma emenda à Constituição. Isso porque é uma casa com um número muito maior de parlamentares e em geral com um grau de adesão ao governo comparativamente menor do que o do Senado. Ou seja, o governo tem de negociar mais na Câmara para fazer valer suas propostas. E não só nas votações em plenário - que incluem, ainda, muito mais DVS do que o Senado -, mas também nas duas comissões com três oportunidades de exercer veto. Desta forma, além do tamanho maior a ser enfrentado é preciso vencer cinco pontos de veto definitivos nesta casa, contra três do Senado.

\footnotetext{
${ }^{80}$ Isso não quer dizer que outros assuntos não motivem os parlamentares. Para além do discurso contrário às perdas físcais dos estados e municípios, houve também aqueles que postularam que os fundos retirariam recursos para áreas sociais, como educação e saúde. Além disso afirmaram também que o governo federal utilizava-se do recurso dos fundos para não realizar uma reforma tributária, que poderia prejudicá-lo.
} 
Nas votações estudadas, o índice de aprovação das duas casas foi semelhante, mas na Câmara houve mais dissidências. Vale uma comparação entre os índices de aprovação médio da Câmara e do Senado. Vamos desconsiderar as votações do FSE, já que o processo foi diferente dos verificados para as votações das emendas 10, 17 e 27. Desta maneira, quando deputados e senadores votaram como tais e dentro do processo convencional, a margem média de aprovação da Câmara foi de $7,77 \%$ e no Senado este índice foi de $10,78 \%$. Ou seja, foi aprovado com mais facilidade na casa federativa.

Também foi na Câmara que ocorreu mais votações nominais, acompanhe:

Tabela 4.23 - Número de votações nominais nas emendas 10, 17 e 27.

\begin{tabular}{|c|c|c|c|c|c|c|c|}
\hline Casa legislativa & \multicolumn{2}{|c|}{ FEF 1} & \multicolumn{2}{|c|}{ FEF 2} & \multicolumn{2}{|c|}{ DRU } & \multirow{2}{*}{ Total } \\
\hline Turno & $\mathbf{1}^{\mathbf{0}}$ & $2^{\circ}$ & $\mathbf{1}^{\mathbf{0}}$ & $2^{\circ}$ & $\mathbf{1}^{\mathbf{0}}$ & $2^{\circ}$ & \\
\hline Câmara & 9 & 4 & 10 & 3 & 9 & 7 & 42 \\
\hline Senado & 1 & 1 & 2 & 1 & 1 & 1 & 7 \\
\hline
\end{tabular}

Fonte: Elaboração própria, a partir dos sites do Senado Federal (www.senado.gov.br) e da Câmara dos Deputados (www.camara.gov.br).

Do total de 49, 12 eram previstas (24,49\%), as votações nominais em turno e returno. Então, tivemos 37 a partir de destaques. Destes, 36 foram na Câmara, onde 91,10\% delas foram pedidas pelos partidos de oposição. Esta é mais uma indicação de que a controvérsia tem fundo partidário e está concentrada na Câmara dos Deputados.

Como vimos no capítulo dois, para uma emenda constitucional não há uma obrigatoriedade de entrar em uma ou outra casa para início de tramitação e votação, ao contrário do que ocorre nos projetos de lei e outras iniciativas externas ao Legislativo - que tem início na Câmara. Mas no caso em tela, as emendas iniciaram sua tramitação na Câmara e isso deu um viés de preferência a ela, pois delibera e pode até vetar primeiro e em definitivo a PEC, sem que nem chegue à casa federativa. Depois, o envio de sua aprovação para o Senado pode fazer com que esta casa, em tese, 1) delibere menos sobre o projeto (pois ele já tramitou em duas comissões, duas votações nominais, com cada etapa podendo vetar a PEC em definitivo) e 2) leve em conta a legitimidade alcançada na Câ- 
mara com, teoricamente, uma predisposição menor de vetar o projeto, tanto na CCJ como nas duas votações nominais.

Assim sendo, o Senado comportou-se como uma câmara revisora, mesmo estando em pauta um tema federativo que deveria, em tese, ser de sua especial atenção. Já a Câmara levaria em consideração o comportamento do Senado, tanto com relação ao embate de forças entre governo e oposição, como a, digamos, maior sensibilidade desta casa com respeito aos temas federativos. Estes dois fatores influenciariam a Câmara em suas duas comissões e nas duas votações nominais.

Em síntese, o Senado tem poder de veto, mas está longe de exercê-lo, pois as regras legislativas não privilegiam o tema federativo dentre outros, a divisão política é principalmente em torno de interesses partidários e a liderança do governo Fernando Henrique Cardoso (em particular) foi capaz de levar à frente uma coalizão grande e disciplinada, tornando o cenário tal como alertado por Stepan em seus artigos de realização improvável.

Isso não quer dizer que o Senado enquanto instituição de cunho federativo não tenha importância - mesmo porque ele tem exclusividade constitucional na área financeira dos entes, além de mais atribuições exclusivas que a Câmara - mas que as discussões sobre os temas mais sensíveis deste ponto de vista estão misturados com outros interesses e subordinados, sobretudo, com as divisões políticas e ideológicas situadas no sistema partidário. 


\section{Conclusões}

Acompanhamos vários aspectos sobre a relação entre o federalismo e a democracia. Tomamos como ponto de partida o argumento de Stepan (1999) a respeito do poder de restrição ao demos nacional, exercido pelo federalismo. Procuraremos repassar as principais questões com o objetivo de conferir um sentido de conjunto ao trabalho.

Embora o federalismo possa funcionar sob um regime autoritário, ele só tem segurança de permanência em uma democracia, alicerçado nos pilares do pacto constitucional e da legitimidade eletiva dos representantes dos entes que formam a federação.

A visão de Stepan prioriza o modelo majoritário de democracia, no qual uma maioria que não representa, necessariamente, a maior parte da população deve governar, desde que vença um processo eleitoral. Baseado nisso, entende que o federalismo constrange o poder do centro nacional, pois este tem de dividi-lo com as maiorias regionalmente localizadas que não representariam, em todos os casos, a vontade da população do conjunto do país, alocada no governo nacional.

Esta visão não levaria em consideração o caráter diverso de um sistema federativo, baseado numa sociedade que valoriza mais as diferenças sob uma mesma unidade política que as reúne. Nesta linha, o federalismo estaria mais de acordo com um modelo consociativo de democracia, tal como postulado por Lijphart (2003), que procura dar voz à maior maioria possível da população, integrando, antes que excluindo os grupos minoritários de uma sociedade. Este modelo estaria mais voltado aos países com sérios problemas em seu interior, com clivagens de ordem étnica, linguística e/ou religiosa, constituindo mesmo nações dentro de um só Estado. Nesse sentido, é possível admitir que o argumento de Stepan faça mais sentido se aplicado a países federativos sem estes problemas, como os casos do Brasil e dos Estados Unidos, por exemplo.

Partindo deste ponto, avançamos para o capítulo dois em que analisamos uma das instituições presentes no federalismo, a câmara alta. Ela procura representar as unidades constituintes no parlamento nacional. A motivação segue Stepan, pois ele identificou esta instituição como a geradora potencial de restrição às decisões do governo nacional. 
Entramos na interpretação do federalismo brasileiro, sob o ponto de vista da atuação de sua câmara alta, o Senado Federal. Dividimos em dois pontos: 1) a extensão do poder entre as duas casas legislativas e 2) como o caráter desproporcional da representação presente nas duas câmaras pode influir em propostas que visem alterar a Constituição.

No primeiro aspecto o bicameralismo brasileiro situa-se entre o meio-forte e o forte, pois é incongruente do ponto de vista representativo e moderadamente assimétrico - a favor da Câmara dos Deputados - pelo lado da equivalência dos poderes na prática do processo legislativo. Mas a questão importante para o nosso caso é o das propostas que alteram a Constituição, pois é a que, em tese, trata das questões de maior substância (polity), e entre elas, as de impacto federativo. E neste particular as duas câmaras são simétricas, atuam com os mesmos poderes.

Para o segundo aspecto tomamos como base analítica a divisão tradicional entre as três regiões menos desenvolvidas e populosas do Norte, Nordeste e Centro-Oeste - com sobrerepresentação - e as duas regiões mais desenvolvidas e populosas do Sudeste e do Sul - com alto grau de subrepresentação para o estado de São Paulo.

Por meio da ação de veto à aprovação de emendas constitucionais procuramos responder 1) se o Senado pode vetar qualquer mudança e 2) se caso a Câmara tivesse sua desproporcionalidade corrigida, poderia evitar o poder de vetar do Senado.

Os resultados mostram que as regiões Norte, Nordeste e Centro-Oeste podem aprovar e vetar qualquer alteração à Constituição no Senado, corroborando o que Stepan afirma em seu artigo. Mas isso não seria suficiente para constranger as duas regiões mais populosas e sub-representadas, pois como uma PEC é votada nas duas casas, na Câmara as regiões Sudeste e Sul somadas vetariam o que tivesse sido aprovado no Senado. Ou seja, estas duas regiões são minoria nas duas casas, mas podem, se for o caso, evitar uma mudança agindo na Câmara. Isso mostra que os argumentos sobre um federalismo demos constraining no Brasil devem ser relativizados, pois não há maioria regional que possa prevalecer.

Já quanto à segunda indagação, os dados mostraram que caso a desproporcionalidade na Câmara dos Deputados fosse corrigida, a região Sudeste vetaria sozinha uma mudança na Constituição, com metade dos seus votos alocados no estado de São Paulo. Se, por um lado, a correta proporcionalidade conferiria uma representação mais democrática, do ponto de vista federativo ela tra- 
ria ainda mais desequilíbrio entre as regiões brasileiras, tomando um caminho contrário a um princípio mais consociativo que deve estar presente em uma federação. Nesse sentido, se a situação atual espanta pelo déficit elevado de representantes no estado mais rico e populoso do país, não chega a ser necessariamente um problema sério, pois é possível que os interesses deste estado - e sua região Sudeste - sejam protegidos na Câmara (em associação com a região Sul). Em suma, evita-se uma eventual prevalência de interesse de uma região sobre as outras.

No capítulo três abordamos o impacto do federalismo no governo de Fernando Henrique Cardoso (1995-2002), tomando como base uma de suas principais características, o seu amplo processo de reformas das estruturas do Estado, por meio de alterações no texto constitucional.

Pois a maior parte das emendas aprovadas tiveram impacto sobre a estutura federativa do país, principalmente do ponto de vista das relações fiscais e da aplicação das políticas sociais, como saúde e educação. Com isso, o governo federal reverteu sua posição desfavorável em relação aos estados do período pré-1994. Em termos fiscais, concentrou mais recursos tributários, reduzindo o nível de autonomia dos estados, além de renegociar as dívidas enormes que os estados haviam adquirido. Em termos sociais, vinculou constitucionalmente os gastos dos estados e municípios em setores como educação e saúde, com possibilidade de intervenção e interrupção de repasse em caso de descumprimento. Este novo contexto fortaleceu a União e reverteu, em parte, o processo descentralizador consagrado a partir de 1988.

No próximo capítulo aprofundamos o estudo do aspecto fiscal, através da análise de como ocorreram as rodadas de renegociação das dívidas dos estados junto à União e como se processaram as tramitações e as votações nominais das PECs dos fundos fiscais. Procuramos verificar, principalmente com relação aos fundos, o papel desempenhado pelo Senado, se mais de acordo com os interesses federativos (regionais) ou partidários (nacionais). A intenção foi tentar enfrentar na prática as dúvidas normativas levantadas por Stepan.

Os estados ficaram mais fracos em relação à União, depois da renegociação das dívidas. Como vimos, os condicionamentos foram grandes e o principal fato foi a extinção e/ou privatização da maioria dos bancos estaduais, a principal fonte de dívidas dos governos estaduais. A União também ficou mais forte com a aprovação do Fundo Social de Emergência, que desvinculou 20\% do que seria repassado aos estados e municípios através dos Fundos de Participação. Contudo, a cada nova renovação dos fundos - renomeados de Fundo de Estabilização Fiscal - os governos subna- 
cionais foram reduzindo suas perdas - especialmente os municípios - até a criação da Desvinculação das Receitas da União, que não mais retirou parte do que seria repassado aos governos subnacionais.

O resultado das votações das PECs no Senado Federal mostra que a instituição não constrange o demos no país mas, ao contrário, vota em colaboração com os interesses do governo federal. Ou seja, a divisão básica de interesses ocorre no campo partidário e não regional. Os temas articulam-se nos partidos, entre os que apóiam o governo e aqueles que fazem oposição. Inclusive, a maioria dos votos contrários está com os senadores dos partidos oposicionistas. Desta maneira, a oposição partidária é que defende os interesses federativos, independentemente das regiões aos quais os senadores pertencem. Por outro lado, os governistas defendem os interesses da União, mesmo aqueles das regiões sobre-representadas. Em suma, o discurso de cunho regional está no contexto das discussões, mas ocorre no embate entre governo e oposição.

A análise das tramitações e votações mostrou também que é na Câmara dos Deputados onde acontece mais deliberação sobre os temas de interesse federativo. Razões para isso incluem uma dificuldade maior do governo federal em negociar nesta casa, com mais parlamentares e em geral mais oposição do que no Senado. Além disso, os trâmites do processo incluem mais situações de intervenção por parte dos deputados - com a apresentação de vários destaques de votação em separado - e mais votações com poder terminativo, pois além dos dois turnos, há uma votação na Comissão de Constituição e Justiça e Cidadania e duas nas Comissões Especiais.

A estrutura política da democracia brasileira é consociativa com sistema de governo presidencialista, um Legislativo nacional bicameral, um sistema eleitoral proporcional, com lista aberta e coligações partidárias para as eleições dos deputados federal, estadual e vereadores, além de vários partidos e sob um formato de divisão interna federativo. Contudo, como mostramos, as decisões em nível nacional se estruturam principalmente pelo protagonismo da agenda do poder Executivo e sua relação com um sistema partidário disciplinado, entre os membros da coalizão de governo e a oposição.

Vimos que a desproporcionalidade pode gerar situações de favorecimento às três regiões menos populosas, por poderem aprovar uma PEC no Senado, ao passo que as duas regiões subrepresentadas não têm como aprovar legislação em nenhuma das duas casas, mas só vetar. Mas em termos concretos, pelo menos nas situações analisadas, tanto em pormenor no capítulo quatro, como 
em termos gerais no capítulo três, o poder Executivo prevalece, desde que tenha um apoio partidário que sustente suas propostas.

Desta maneira não são as duas primeiras variáveis institucionais apresentas por Stepan no capítulo um - o grau de sobre-representação e o poder das câmaras altas -, as mais decisivas, mas aquela que ele nomeou como a quarta - e que na verdade é uma conseqüência - a da influência do sistema partidário. Pois este era um dos mais importantes argumentos de Riker (1964), a de que o sistema partidário prevalece sobre as instituições federativas, porque as articulações e decisões ocorrem sob o manto do interesse prioritariamente nacional, através do embate entre os partidos que apóiam e se opõem ao governo.

É claro que este não é um trabalho completo sobre a democracia federativa brasileira, que tem suas vitalidades e debilidades também expressas tanto em suas contradições socieconômicas, como em sua configuração institucional descentralizada e nos poderes políticos regionais e historicamente localizados. O que exploramos foram aspectos importantes do ponto de vista normativo, procurando mostrar os efeitos concretos nos casos analisados. 


\section{Referências Bibliográficas}

ABRUCIO, Fernando (1998). Os Barões da Federação. Hucitec e Edusp.

ABRUCIO, Fernando (2005). “A Cooperação Federativa no Brasil: A Experiência do Período FHC e os Desafios do Governo Lula”, Revista de Sociologia e Política, n.24, junho.

ABRUCIO, Fernando e COSTA, Valeriano Mendes Ferreira (1998). Reforma do Estado e o Contexto Federativo Brasileiro. Konrad-Adenauer-Stiftung - Série Pesquisas n. 12.

ALMEIDA, Maria Hermínia Tavares de (2001). "Federalismo, Democracia e Governo no Brasil: Idéias, Hipóteses e Evidências”, BIB, n.51.

ALMEIDA, Maria Hermínia Tavares de (2005). “Recentralizando a Federação?”, Revista de Sociologia e Política, n.24, junho.

AMORIM NETO, Octavio e TAFNER, Paulo (2002). “Governos de Coalizão e Mecanismos de Alarme de Incêndio no Controle Legislativo das Medidas Provisórias”, Dados, vol. 45, n.1.

ARRETCHE, Marta (2001). "Federalismo e Democracia no Brasil: A Visão da Ciência Política Norte-Americana", São Paulo em Perspectiva (15), novembro/dezembro.

ARRETCHE, Marta (2002). “Federalismo e Relações Intergovernamentais no Brasil: A Reforma de Programas Sociais", Dados, vol.45, n.3.

ARRETCHE, Marta (2004). "Federalismo e Políticas Sociais no Brasil: Problemas de Coordenação e Autonomia”, São Paulo em Perspectiva, 18 (2).

ARRETCHE, Marta (2005). “Quem Taxa e Quem Gasta: a Barganha Federativa na Federação Brasileira”, Revista de Sociologia e Política, n.24, junho.

ARRETCHE, Marta (2007). "Representação Territorial e Poder de Veto: Examinando a Agenda Federativa Brasileira", mimeo.

ASSOCIAÇÃO PAULISTA DE MEDICINA (2001). S.U.S. - O que Você Precisa Saber, Volume II, São Paulo. 
BACKES, Ana Luíza (1998). Democracia e Sobre-Representação de Regiões: O Papel do Senado. Dissertação de mestrado pelo Departamento de Ciência Política da Universidade de Brasília.

BRASIL (2002a). “Dívida Pública: Conceitos Básicos e Fatores Determinantes”, Ministério da Fazenda - Secretaria da Receita Federal, junho.

BRASIL (2002b). Sistema e Administração Tributária - Uma Visão Geral, Estudo Tributário no.8, Ministério da Fazenda - Secretaria da Receita Federal, agosto.

BRASIL (2003). "Vinculações de Receitas dos Orçamentos Fiscal e da Seguridade Social e o Poder Discricionário de Alocação dos Recursos do Governo Federal”, Ministério do Planejamento, Orçamento e Gestão, fevereiro.

BRASIL (2007a). Constituição da República Federativa do Brasil. Editora Escala.

BRASIL (2007b). Endereço eletrônico na internet da Câmara dos Deputados: www.camara.gov.br.

BRASIL (2007c). Endereço eletrônico na internet do Senado Federal: www.senado.gov.br.

BRASIL (2007d). Endereço eletrônico na internet da Secretaria do Tesouro Nacional: www.tesouro.gov.br.

BRASIL (2007e). Endereço eletrônico na internet do Instituto Brasileiro de Geografia e Estatística: www.ibge.gov.br

CARVALHO, José Murilo de (1993). “Federalismo y Centralizacíon en El Imperio Brasileño: Historia y Argumento", Federalismos Latinoamericanos - México, Brasil, Argentina. Marcello Carmagnani, org. Fondo de Cultura, Cidade do México.

COUTO, Cláudio Gonçalves (2001). “O Avesso do Avesso: Conjuntura e Estrutura na Recente Agenda Política Brasileira", São Paulo em Perspectiva (15), novembro/dezembro.

COUTO, Cláudio Gonçalves e ABRUCIO, Fernando (2003). “O Segundo Governo FHC: Coalizões, Agendas e Instituições”, Tempo Social, vol. 15, n.2, novembro. 
COUTO, Cláudio Gonçalves e ARANTES, Rogério Bastos (2002). “Constituição ou Políticas Públicas? Uma Avaliação dos Anos FHC", O Estado Numa Era de Reformas: Os Anos FHCParte 1, Fernando Abrucio e Maria Rita Loureiro, orgs. Ministério do Planejamento, Orçamento e Gestão da Presidência da República.

COUTO, Cláudio Gonçalves e ARANTES, Rogério Bastos (2006). “Constituição, Governo e Democracia no Brasil”, Revista Brasileira de Ciências Sociais, volume 21, n.61, junho.

DAHL, Robert (1997 [1972]). Poliarquia - Participação e Oposição. Edusp.

DUCHACEK, Ivo (1970). Comparative Federalism: The Territorial Dimension of Politics. Santa Barbara, Holt, Rinehart and Winston Inc.

FIGUEIREDO, Argelina (2006). "Formação, Funcionamento e Desempenho das Coalizões de Governo no Brasil". Trabalho apresentado no quinto encontro da Associação Brasileira de Ciência Política, Belo Horizonte, julho.

FIGUEIREDO, Argelina e LIMONGI, Fernando (1999). Executivo e Legislativo na Nova Ordem Constitucional. Editora FGV e Fapesp.

GARMAN, Christopher, LEITE, Cristiane Kerches da Silva e MARQUES, Moisés da Silva (2001). “Impactos das Relações Banco Central x Bancos Estaduais no Arranjo Federativo pós-1994: Análise à Luz do Caso Banespa”, Revista de Economia Política, vol. 21, n.1 (81), janeiro/março.

GIBSON, Edward (2004). "Federalism and Democracy: Theorical Connections and Cautionary Insights", Federalism and Democracy in Latin America, Edward L. Gibson, org. The Johns Hopkins University Press.

JUNG, Winfried, org. (1995). "O Conselho Federal”, O Federalismo na Alemanha. KonradAdenauer-Stiftung - Série Traduções n. 7.

KING, Preston (1982). Federalism and Federation. Croom Helm, Londres.

KING, Preston (1993). "Federalism and Representation", Comparative Federalism and Federation, Alain Gagnon e Michael Burgess, orgs. University of Toronto Press. 
KUGELMAS, Eduardo e SOLA, Lourdes (2000). "Recentralização/Descentralização: Dinâmica do Regime Federativo no Brasil dos Anos 90”, Tempo Social, vol. 11, no. 2, fevereiro.

LEME, Heládio José de Campos (1992). O Federalismo na Constituição de 1988: Representação Política e a Distribuição de Recursos Tributários. Dissertação de mestrado em Ciência Política na Universidade Estadual de Campinas.

LIJPHART, Arend (2003). Modelos de Democracia: Desempenho e Padrões de Governo em 36 Países. Editora Civilização Brasileira.

LINZ, Juan (1983). “The Transition from an Authoritarian Regime to Democracy in Spain: Some Thoughts for Brazilians". Yale University Press, mimeo.

LINZ, Juan e STEPAN, Alfred (1999). A Transição e Consolidação da Democracia - A Experiência do Sul da Europa e da América do Sul. Editora Paz e Terra.

LLANOS, Mariana (2002). "El Bicameralismo en América Latina", Arbeitspapier n.5, Institute für Iberoamericka-Kunde, Hamburgo, setembro.

LOUREIRO, Maria Rita (2001). “O Senado no Brasil Recente: Política e Ajuste Fiscal”, São Paulo em Perspectiva (15), novembro/dezembro.

MADISON, James, HAMILTON, Alexander e JAY, John. (1993 [1788]). Os Artigos Federalistas. Editora Nova Fronteira.

MELO, Marcus André (2005). “O Sucesso Inesperado das Reformas de Segunda Geração: Federalismo, Reformas Constitucionais e Política Social”, Dados, vol. 48, n.4.

MORA, Mônica (2002). Federalismo e Dívida Estadual no Brasil. Texto para Discussão 866, Instituto de Política Econômica Aplicada, março.

NICOLAU, Jairo (1997). “As Distorções na Representação dos Estados na Câmara dos Deputados Brasileira", Dados, vol.40, n.3.

OLIVEIRA, Arlindo Fernandes de (2004). “Sobre a Representação dos Estados na Câmara dos Deputados", Revista de Informação Legislativa, n.141, janeiro/março. 
PATTERSON, Samuel C. e MUGHAN, Anthony (1999a). "Senates and the Theory of Bicameralism", Senates: Bicameralism in the Contemporary World, Samuel C. Patterson e Anthony Mughan, orgs. Ohio State University Press/Columbus.

PATTERSON, Samuel C. e MUGHAN, Anthony (1999b). "Senates: A Comparative Perspective”, Senates: Bicameralism in the Contemporary World, Samuel C. Patterson e Anthony Mughan, orgs. Ohio State University Press/Columbus.

PULS, Maurício (2002). "Distorção na Câmara Deu Unidade ao País”, Folha de S. Paulo, 10 de novembro.

RIGOLON, Francisco e GIAMBIAGI, Fábio (1999). A Renegociação das Dívidas e o Regime Fiscal dos Estados. Textos para Discussão 69, Banco Nacional de Desenvolvimento Econômico e Social, julho.

RIKER, William (1964). Federalism: Origin, Operation, Significance. Boston, Little \& Brown.

RIKER, William (1975). "Federalism", Handbook of Political Science - Vol.5, F. Greenstein e N.W. Polsby, orgs. Reading/Addison-Wesley, Massashusetts.

RIKER, William (1993). "Federalism", A Companion to Contemporary Political Philosophy, Robert E. Goodin e Philip Pettit, editores. Blackwell Publishers.

SALLUM JR., Brasílio (1996). "Federação, Autoritarismo e Democratização”, Tempo Social, vol. 8 , no. 2 , outubro.

SALLUM, JR., Brasílio (2003). "Metamorfoses do Estado Brasileiro no Final do Século XX”, Revista Brasileira de Ciências Sociais, volume 18, n.52, junho.

SAMUELS, David (2003a). “A Economia Política da Reforma Macroeconômica no Brasil, 1995-2002”, Dados, vol. 46, n.4. 
SAMUELS, David (2003b). "The Cardoso Administration and Changes in Brazilian Federalism", capítulo nove de Ambition, Federalism, and Legislative Politics in Brazil, David Samuels. Cambridge University Press.

SANTOS, Wanderley Guilherme dos (1987). Crise e Castigo - Partidos e Generais na Política Brasileira. Editora Vértice/Iuperj.

SNYDER, RICHARD e SAMUELS, David (2004). "Legislative Malapportionment in Latin America - Historical and Comparative Perspectives", Federalism and Democracy in Latin America, Edward L. Gibson, org. The Johns Hopkins University Press.

SOARES, Márcia Miranda e LOURENÇO, Luiz Cláudio (2004). “A Representação Política dos Estados na Federação Brasileira”, Revista Brasileira de Ciências Sociais, vol.19, n.56, outubro.

SOUZA, Celina (2001). "Federalismo e Descentralização na Constituição de 1988: Processo Decisório, Conflitos e Alianças", Dados, vol. 44, n. 3.

SOUZA, Celina (2005). "Federalismo, Desenho Constitucional e Instituições Federativas no Brasil Pós-1988”, Revista de Sociologia e Política, n.24, junho.

STEPAN, Alfred (1999). "Para uma Nova Análise Comparativa do Federalismo e da Democracia: Federações que Restringem ou Ampliam o Poder do Demos", Dados, vol. 42, no. 2.

STEPAN, Alfred (2002). “O Federalismo Descentralizado do Brasil: Aproximando o Governo dos Cidadãos?”, Brasil: Fardo do Passado, Promessa do Futuro, Leslie Bethell, org. Civilização Brasileira.

STEPAN, Alfred (2004a). "Toward a New Comparative Politics of Federalism, Multinationalism, and Democracy - Beyond Rikerian Federalism”, Federalism and Democracy in Latin America, Edward L. Gibson, org. The Johns Hopkins University Press.

STEPAN, Alfred (2004b). "Electorally Generated Veto Players in Unitary and Federal Systems", Federalism and Democracy in Latin America, Edward L. Gibson, org. The Johns Hopkins University Press. 
TEIXEIRA, José Raimundo Baganha (2005). “O Atual Desequilíbrio no Sistema de Repartição de Receitas Tributárias", Consultoria Legislativa - Estudo. Câmara dos Deputados, maio.

TIEBOLT, Charles (1956). “A Pure Theory of Local Expenditures”, Journal of Political Economy n.64, vol. 5.

TSEBELIS, George e MONEY, Jeannete (1997). Bicameralism. New York, Cambridge University Press. 


\section{ANEXOS \\ 1 - Propostas de emendas constitucionais aprovadas no governo de Fer- nando Henrique Cardoso (1995-2002).}

\section{PRIMEIRO MANDATO (1995-1998)}

EMC 5 - Sobre a exploração do gás canalizado por parte dos Estados.

PEC 4/1995 - Câmara dos Deputados (CD) e PEC 29/1995 - Senado Federal (SF).

Tema: FEDERATIVO - (GOVERNAMENTAL).

Autor: Poder Executivo.

Início da tramitação na Câmara dos Deputados: 20/2/1995.

Remessa ao Senado Federal: 16/5/1995.

Promulgação: 15/8/1995.

EMC 6 - Sobre a eliminação de distinção entre empresa brasileira e entre empresa brasileira de capital nacional, possibilidade de investimentos estrangeiros em mineração e recursos hidráulicos.

PEC 5/1995 - CD e PEC 32/1995 - SF.

Tema: ECONÔMICO.

Autor: Poder Executivo.

Início da tramitação na Câmara dos Deputados: 20/2/1995.

Remessa ao Senado Federal: 23/5/1995.

Promulgação: 15/8/1995.

EMC 7 - Retira da Constituição Federal dispositivos sobre a utilização de barcos de pesca, transporte de granéis, a predominância de armadores nacionais, navios de bandeira e registros brasileiros no comercio internacional ou mesmo a definição de embarcações nacionais. Ou seja, permite a navegação de cabotagem por barcos estrangeiros.

PEC 7/1995 - CD e PEC 33/1995 - SF.

Tema: FEDERATIVO - (GOVERNAMENTAL).

Autor: Poder Executivo.

Início da tramitação na Câmara dos Deputados: 20/2/1995.

Remessa ao Senado Federal: 31/5/1995. 
Promulgação: 15/8/1995.

EMC 8 - Torna flexível a restrição imposta pela União à exclusividade na exploração dos serviços públicos de telecomunicações, por empresas de controle acionário estatal, sem retirar do Estado seu poder regulador.

PEC 3/1995 - CD e PEC 36/1995 - SF.

Tema: ECONÔMICO.

Autor: Poder Executivo.

Início da tramitação na Câmara dos Deputados: 20/2/1995.

Remessa ao Senado Federal: 6/6/1995.

Promulgação: 15/8/1995.

EMC 9 - Sobre a flexibilização do monopólio do petróleo, tornando possível a exploração por empresas privadas.

PEC 6/1995 - CD e PEC 39/1995 - SF.

Tema: ECONÔMICO.

Autor: Poder Executivo.

Início da tramitação na Câmara dos Deputados: 16/2/1995.

Remessa ao Senado Federal: 20/6/1995.

Promulgação: 9/11/1995.

EMC 10 - Altera os artigos 71 e 72 do Ato das Disposições Constitucionais Transitórias (ADCT). É sobre a renovação do Fundo Social de Emergência, com o novo nome de Fundo de Estabilização Fiscal.

PEC 163/1995 - CD e PEC 68/1995 - SF.

Tema: FEDERATIVO - (FISCAL).

Autor: Poder Executivo.

Início da tramitação na Câmara dos Deputados: 16/8/1995.

Remessa ao Senado Federal: 22/11/1995.

Promulgação: 4/3/1996.

EMC 11 - Permite a admissão de professores, técnicos e cientistas estrangeiros pelas universidades brasileiras e concede autonomia às instituições de pesquisa científica e tecnológica.

PEC 192/1994 - CD e PEC 61/1995 - SF. 
Tema: INSTITUCIONAL.

Autor: Deputado Sérgio Arouca (PPS-RJ).

Início da tramitação na Câmara dos Deputados: 16/6/1994.

Remessa ao Senado Federal: 9/10/1995.

Promulgação: 30/4/1996.

EMC 12 - Outorga competência à União para instituir contribuição provisória sobre movimentação ou transmissão de valores e de créditos e direitos de natureza financeira.

PEC 256/1995 - CD e PEC 40/1995.

Tema: FEDERATIVO - (FISCAL).

Autor: Senador Antonio Carlos Valadares (PP-SE).

Início da tramitação no Senado Federal: 10/11/1995.

Remessa à Câmara dos Deputados: 29/11/1995.

Promulgação: 15/8/1996.

EMC 13 - Dá nova redação ao inciso II do artigo 192 da Constituição Federal sobre a autorização e funcionamento dos estabelecimentos de seguro, resseguro, previdência e capitalização, bem como do órgão oficial fiscalizador.

PEC 48/1995 - CD e PEC 1/1996 - SF.

Tema: ECONÔMICO.

Autor: Deputado Cunha Bueno (PPR-SP).

Início da tramitação na Câmara dos Deputados: 6/4/1995.

Remessa ao Senado Federal: 13/12/1995

Promulgação: 21/8/1996.

EMC 14 - Modifica os artigos 34, 208, 211 e 212 e dá nova redação ao artigo 60 do ADCT. É sobre a criação do Fundo de Manutenção e Desenvolvimento do Ensino Fundamental e de Valorização do Magistério (Fundef).

PEC 233/1995 - CD e PEC 30/1996 - SF.

Tema: FEDERATIVO - (SOCIAL).

Autor: Poder Executivo.

Início da tramitação na Câmara dos Deputados: 23/10/1995.

Remessa ao Senado Federal: 25/6/1996.

Promulgação: 12/9/1996. 
EMC 15 - Dá nova redação ao parágrafo $4^{\circ}$ do artigo 18 sobre a criação, incorporação, fusão e o desmembramento de municípios.

PEC 41/1991 - CD e PEC 22/1996 - SF.

Tema: FEDERATIVO - (POLÍTICO).

Autor: Deputado Cesar Bandeira (PFL-MA).

Início da tramitação na Câmara dos Deputados: 29/8/1991.

Remessa ao Senado Federal: 13/5/1996.

Promulgação: 12/9/1996.

EMC 16 - Sobre a instauração da reeleição para os cargos executivos em nível federal, estadual e municipal.

PEC 1/1995 - CD e PEC 4/1997 - SF.

Tema: INSTITUCIONAL.

Autor: Deputado Mendonça Filho (PFL-PE).

Início da tramitação na Câmara dos Deputados: 16/2/1995.

Remessa ao Senado Federal: 26/2/1997.

Promulgação: 4/6/1997.

EMC 17 - Altera os dispositivos dos artigos 71 e 72 do ADCT. É sobre a segunda renovação do Fundo Social de Emergência (Fundo de Estabilização Fiscal).

PEC 449/1997 - CD e PEC 25/1997 - SF.

Tema: FEDERATIVO - (FISCAL).

Autor: Poder Executivo.

Início da tramitação na Câmara dos Deputados: 6/3/1997.

Remessa ao Senado Federal: 14/8/1997.

Promulgação: 22/11/1997.

EMC 18 - Dispõe sobre o regime constitucional dos militares, diferenciando-os do servidor público civil.

PEC 338/1996 - CD e PEC 39/1997 - SF.

Tema: INSTITUCIONAL.

Autor: Poder Executivo.

Início da tramitação na Câmara dos Deputados: 10/4/1996.

Remessa ao Senado Federal: 28/10/1997. 
Promulgação: 5/2/1998.

EMC 19 - Modifica o regime e dispõe sobre princípios e normas da Administração Pública.

PEC 173/1995 - CD e PEC 41/1997 - SF.

Tema: FEDERATIVO - (GOVERNAMENTAL).

Autor: Poder Executivo.

Início da tramitação na Câmara dos Deputados: 23/8/1995.

Remessa ao Senado Federal: 1/12/1997.

Promulgação: 4/6/1998.

EMC 20 - Modifica o sistema de previdência social.

PEC 33/1995 - CD e PEC 33/1996 - SF.

Tema: FEDERATIVO - (SOCIAL).

Autor: Poder Executivo.

Início da tramitação na Câmara dos Deputados: 28/3/1995.

Remessa ao Senado Federal: 17/7/1997.

Reenvio do Senado Federal: 10/10/1997.

Promulgação: 15/12/1998.

\section{SEGUNDO MANDATO (1999-2002)}

EMC 21 - Prorroga, alterando a alíquota, a contribuição provisória sobre movimentação ou transmissão de valores e de créditos e de direitos de natureza financeira, a que se refere o artigo 74, do ADCT, com os recursos aplicados à Saúde.

PEC 637/1999 - CD e 34/1998 - SF.

Tema: FEDERATIVO - (FISCAL).

Autor: Deputado Élcio Álvares (PFL-ES).

Início da tramitação na Câmara dos Deputados: 19/1/1999.

Remessa ao Senado Federal: 18/3/1999.

Promulgação: 19/3/1999.

EMC 22 - Criação de juizados especiais no âmbito federal, acréscimo ao artigo 98 (sobre a distribuição de juizados especiais nos três níveis da União).

PEC 526/1997 - CD e PEC 1/1999 - SF. 
Tema: INSTITUCIONAL.

Autor: Poder Executivo.

Início da tramitação na Câmara dos Deputados: 11/11/1997.

Remessa ao Senado Federal: 14/1/1999.

Promulgação: 18/3/1999.

EMC 23 - Criação do Ministério de Estado da Defesa.

PEC 626/1998 - CD e PEC 53/1999 - SF.

Tema: INSTITUCIONAL.

Autor: Poder Executivo.

Início da tramitação na Câmara dos Deputados: 9/12/1998.

Remessa ao Senado Federal: 9/6/1999.

Promulgação: 2/9/1999.

EMC 24 - Altera dispositivos da Constituição Federal pertinentes à representação classista na Justiça do Trabalho.

PEC 33/1999 - CD e PEC 63/1995 - SF.

Tema: INSTITUCIONAL.

Autor: Senador Gilberto Miranda (PFL-AM).

Início da tramitação no Senado Federal: 20/10/1995.

Remessa à Câmara dos Deputados: 21/6/1999.

Promulgação: 9/12/1999.

EMC 25 - Sobre o limite de despesas com o Poder Legislativo nos municípios.

PEC 627/1998 - CD e PEC 15-A/1998 - SF.

Tema: FEDERATIVO - (POLÍTICO).

Autor: Senador Espiridião Amin (PPB-SC).

Início da tramitação no Senado Federal: 25/3/1998.

Remessa à Câmara dos Deputados: 16/12/1998.

Promulgação: 14/2/2000.

EMC 26 - Nova redação sobre direitos sociais, como a educação, saúde, trabalho, moradia, lazer, segurança e previdência social.

PEC 601/1998 - CD e PEC 28/1996 - SF. 
Autor: Senador Mauro Miranda (PMDB-GO).

Tema: INSTITUCIONAL.

Início da tramitação no Senado Federal: 18/6/1996

Remessa à Câmara dos Deputados: 1/6/1998.

Promulgação: 14/2/2000.

EMC 27 - Acrescenta o artigo 76 ao ADCT, instituindo a Desvinculação das Receitas da União (DRU). É a terceira renovação do Fundo Social de Emergência.

PEC 85/1999 - CD e PEC 4/2000 - SF.

Tema: FEDERATIVO - (FISCAL).

Autor: Poder Executivo.

Início da tramitação na Câmara dos Deputados: 14/9/1999.

Remessa ao Senado Federal: 27/1/2000.

Promulgação: 21/3/2000.

EMC 28 - Da nova redação ao inciso XXIX do artigo $7^{\circ}$ sobre prescrição da ação trabalhista e revoga o artigo 233.

PEC 7/1999 - CD e PEC 64/1995 - SF.

Tema: ECONÔMICO.

Autor: Senador Osmar Dias (PSDB-PR).

Início da tramitação no Senado Federal: 25/3/1999.

Remessa à Câmara dos Deputados: 16/4/1999.

Promulgação: 25/5/2000.

EMC 29 - Assegura os recursos mínimos para o financiamento das ações dos serviços públicos de saúde, o Sistema Único de Saúde (SUS).

PEC 82/1995 - CD e PEC 86/1999 - SF.

Tema: FEDERATIVO - (SOCIAL).

Autor: Deputado Carlos Mosconi (PSDB-MG).

Início da tramitação na Câmara dos Deputados: 27/4/1995.

Remessa ao Senado Federal: 11/9/1999.

Promulgação: 13/9/2000. 
EMC 30 - Altera a redação do artigo 100 e acrescenta o artigo 78 ao ADCT, referente ao pagamento de precatórios judiciais, por parte da União, estados e municípios.

PEC 407/1996 - CD e PEC 90/1999 - SF.

Tema: FEDERATIVO - (FISCAL).

Autor: Deputado Luciano Castro (PSDB-RR).

Início da tramitação na Câmara dos Deputados: não encontrado.

Remessa ao Senado Federal: 9/12/1999.

Promulgação: 13/9/2000.

EMC 31 - Acrescenta os artigos 79, 80, 81 e 82 ao ADCT, introduzindo o Fundo de Combate e Erradicação da Pobreza.

PEC 249/2000 - CD e PEC 67/1999 - SF.

Tema: FEDERATIVO - (SOCIAL).

Autor: Senador Antônio Carlos Magalhães (PFL-BA).

Início da tramitação no Senado Federal: 30/5/2000.

Remessa à Câmara dos Deputados: 14/6/2000.

Promulgação: 14/12/2000.

EMC 32 - Estabelece critérios para edição de Medida Provisoria, proibindo a reedição, na mesma Sessão Legislativa de medida que tenha sido objeto de rejeição ou tenha perdido sua eficacia por decurso de prazo, que no caso é de 90 dias. É admitida a prorrogação por igual periodo, alterando a Constituição Federal.

PEC 472/1997 - CD e PEC 1-B/1995 - SF.

Tema: INSTITUCIONAL.

Autor: Senador Espiridião Amin (PPB-SC).

Início da tramitação no Senado Federal: 15/5/1997.

Remessa à Câmara dos Deputados: 11/6/1997.

Promulgação: 11/9/2001.

EMC 33 - Altera os artigos 149, 155 e 177 sobre contribuições sociais e de intervenção no domínio econômico (CIDE), entrada de bem ou mercadoria importados do exterior por pessoa física e jurídica, assim como comercialização de petróleo e seus derivados etc.

PEC 277/2000 - CD e PEC 42/2001 - SF.

Tema: ECONÔMICO. 
Autor: Poder Executivo.

Início da tramitação na Câmara dos Deputados: 10/8/2000.

Remessa ao Senado Federal: 11/10/2001.

Promulgação: 11/12/1001.

EMC 34 - Dá nova redação à alínea c do inciso XVI do artigo 37 sobre cargos ou empregos privativos dos profissionais de saúde.

PEC 308/1996 - CD e PEC 36/2001 - SF.

Tema: INSTITUCIONAL.

Autora: Deputada Jandira Feghali (PCdoB - RJ).

Início da tramitação na Câmara dos Deputados: 24/1/1996.

Remessa ao Senado Federal: 27/9/2001.

Promulgação: 14/12/2001.

EMC 35 - Dá nova radação ao artigo 53 sobre a invibiolabilidade de deputados e senadores, civil e penalmente, por quaisquer de suas opiniões, palavras e votos.

PEC 610/1998 - CD e PEC 2-A/1995 - SF.

Tema: INSTITUCIONAL.

Autor: Senador Ronaldo Cunha Lima (PSDB-PB)

Início da tramitação no Senado Federal: 20/2/1995

Remessa à Câmara dos Deputados: 17/7/1998.

Promulgação: 20/12/2001.

EMC 36 - Dá nova redação ao artigo 222 para permitir a participação de pessoas jurídicas no capital social de empresas jornalísticas e de radiodifusão sonora e sons de imagens, nas condições que especifica.

PEC 203/1995 - CD e PEC 5/2002 - SF.

Tema: ECONÔMICO.

Autor: Deputado Laprovita Vieira (PPB-RJ).

Início da tramitação na Câmara dos Deputados: 20/9/1995.

Remessa ao Senado Federal: 27/2/2002.

Promulgação: 28/5/2002. 
EMC 37 - Prorroga a vigência da Contribuição Provisória sobre Movimentação Financeira (CPMF) até 31 de dezembro de 2004, vigindo a Lei 9311, de 1996 até essa data. (Por desmembramento da PEC 382/01).

PEC 407/2001 - CD e PEC 18/2002 - SF.

Tema: FEDERATIVO - (FISCAL).

Autor: Poder Executivo.

Início da tramitação na Câmara dos Deputados: 29/8/2001.

Remessa ao Senado Federal: 29/4/2002.

Promulgação: 12/6/2002.

EMC 38 - Acrescenta o artigo 89 ao ADCT, incorporando os Policiais Militares do extinto Território Federal de Rondônia aos quadros da União.

PEC 289/2000 - CD e PEC 19/2002 - SF.

Tema: INSTITUCIONAL.

Autor: Poder Executivo.

Início da tramitação na Câmara dos Deputados: 21/9/2000.

Remessa ao Senado Federal: 23/4/2002.

Promulgação: 30/4/2002.

EMC 39 - Contribuição para custeio ao serviço de iluminação pública nos municípios e no Distrito Federal.

PEC 559/2002 - CD e PEC 3/2002.

Tema: FEDERATIVO - (FISCAL).

Autor: Senador Álvaro Dias (PSDB-PR).

Início da tramitação no Senado Federal: 27/2/2002.

Remessa à Câmara dos Deputados: 20/6/2002.

Promulgação: 19/12/2002. 


\section{2 - Textos integrais das emendas constitucionais relativas ao Fundo Social de Emergência e suas renovações.}

\section{EMENDA CONSTITUCIONAL DE REVISÃO N 1 - 1994}

Acrescenta os artigos. 71, 72 e 73 ao Ato das Disposições Constitucionais Transitórias.

A Mesa do Congresso Nacional, nos termos do artigo 60 da Constituição Federal , combinado com o artigo $3 .^{\circ}$ do Ato das Disposições Constitucionais Transitórias, promulga a seguinte emenda constitucional:

Art. 1. ${ }^{\circ}$ Ficam incluídos os arts. 71,72 e 73 no Ato das Disposições Constitucionais Transitórias, com a seguinte redação:

Art. 71. Fica instituído, nos exercícios financeiros de 1994 e 1995, o Fundo Social de Emergência, com o objetivo de saneamento financeiro da Fazenda Pública Federal e de estabilização econômica, cujos recursos serão aplicados no custeio das ações dos sistemas de saúde e educação, benefícios previdenciários e auxílios assistenciais de prestação continuada, inclusive liquidação de passivo previdenciário, e outros programas de relevante interesse econômico e social.

Parágrafo único. Ao Fundo criado por este artigo não se aplica, no exercício financeiro de 1994, o disposto na parte final do inciso II do $\S 9 .^{\circ}$ do artigo 165 da Constituição.

Art. 72. Integram o Fundo Social de Emergência:

I - o produto da arrecadação do imposto sobre renda e proventos de qualquer natureza incidente na fonte sobre pagamentos efetuados, a qualquer título, pela União, inclusive suas autarquias e fundações;

II - a parcela do produto da arrecadação do imposto sobre propriedade territorial rural, do imposto sobre renda e proventos de qualquer natureza e do imposto sobre operações de crédito, câmbio e seguro, ou relativas a títulos ou valores mobiliários, decorrente das alterações produzidas pela Medida Provisória n. ${ }^{\circ} 419$ e pelas 
Leis n. ${ }^{\circ}$ s $8.847,8.849$ e 8.848 , todas de 28 de janeiro de 1994, estendendo-se a vigência da última delas até 31 de dezembro de 1995;

III - a parcela do produto da arrecadação resultante da elevação da alíquota da contribuição social sobre o lucro dos contribuintes a que se refere o $\S 1$. $^{\circ}$ do artigo 22 da Lei n. ${ }^{\circ} 8.212$, de 24 de julho de 1991, a qual, nos exercícios financeiros de 1994 e 1995, passa a ser de trinta por cento, mantidas as demais normas da Lei n. ${ }^{\circ} 7.689$, de 15 de dezembro de 1988;

IV - vinte por cento do produto da arrecadação de todos os impostos e contribuições da União, excetuado o previsto nos incisos I, II e III;

V - a parcela do produto da arrecadação da contribuição de que trata a Lei Complementar . $^{\circ}$, de 7 de setembro de 1970, devida pelas pessoas jurídicas a que se refere o inciso III deste artigo, a qual será calculada, nos exercícios financeiros de 1994 e 1995, mediante a aplicação da alíquota de setenta e cinco centésimos por cento sobre a receita bruta operacional, como definida na legislação do imposto sobre renda e proventos de qualquer natureza;

VI - outras receitas previstas em lei específica.

$\S 1 .^{\circ}$ As alíquotas e a base de cálculo previstas nos incisos III e V aplicar-seão a partir do primeiro dia do mês seguinte aos noventa dias posteriores à promulgação desta Emenda.

$\S 2 .^{\circ}$ As parcelas de que tratam os incisos I, II, III e V serão previamente deduzidas da base de cálculo de qualquer vinculação ou participação constitucional ou legal, não se lhes aplicando o disposto nos artigos 158, II, 159, 212 e 239 da Constituição.

$\S 3 .^{\circ}$ A parcela de que trata o inciso IV será previamente deduzida da base de cálculo das vinculações ou participações constitucionais previstas nos artigos $153, \S$ 5. ${ }^{\circ}, 157$, II, 158, II, 212 e 239 da Constituição.

$\S 4 .^{\circ} \mathrm{O}$ disposto no parágrafo anterior não se aplica aos recursos previstos no artigo 159 da Constituição. 
$\S 5 .^{\circ}$ A parcela dos recursos provenientes do imposto sobre propriedade territorial rural e do imposto sobre renda e proventos de qualquer natureza, destinada ao Fundo Social de Emergência, nos termos do inciso II deste artigo, não poderá exceder:

I - no caso do imposto sobre propriedade territorial rural, a oitenta e seis inteiros e dois décimos por cento do total do produto da sua arrecadação;

II - no caso do imposto sobre renda e proventos de qualquer natureza, a cinco inteiros e seis décimos por cento do total do produto da sua arrecadação.

Art. 73. Na regulação do Fundo Social de Emergência não poderá ser utilizado o instrumento previsto no inciso V do art. 59 da Constituição.

Art. 2. ${ }^{\circ}$ Fica revogado o $\S 4 .^{\circ}$ do art. $2 .^{\circ}$ da Emenda Constitucional n. ${ }^{\circ}$ 3, de 1993.

Art. 3. ${ }^{\circ}$ Esta Emenda entra em vigor na data de sua publicação.

Brasília, 1. de março de 1994.

HUMBERTO LUCENA - Presidente

ADYLSON MOTTA $-1^{\circ}$ Vice-Presidente

LEVY DIAS $-2^{\circ}$ Vice-Presidente

WILSON CAMPOS $-1^{\circ}$ Secretário

NABOR JÚNIOR - $2^{\circ}$ Secretário

AÉCIO NEVES - $3^{\circ}$ Secretário

Este texto não substitui o publicado no Diário Oficial da União de 2 de março de 1994. 


\section{EMENDA CONSTITUCIONAL $\mathrm{N}^{\circ} 10-1996$}

Altera os artigos 71 e 72 do Ato das Disposições Constitucionais Transitórias, introduzidos pela Emenda Constitucional de Revisão nº 1, de 1994.

As Mesas da Câmara dos Deputados e do Senado Federal, nos termos do $\S 3^{\circ}$ do artigo 60 da Constituição Federal, promulgam a seguinte Emenda ao texto constitucional:

Art. $1^{\circ} \mathrm{O}$ artigo 71 do Ato das Disposições Constitucionais Transitórias passa a vigorar com a seguinte redação:

“Art. 71. Fica instituído, nos exercícios financeiros de 1994 e 1995, bem assim no período de $1^{\circ}$ de janeiro de 1996 a 30 de junho de 1997, o Fundo Social de Emergência, com o objetivo de saneamento financeiro da Fazenda Pública Federal e de estabilização econômica, dos sistemas de saúde e educação, benefícios previdenciários e auxílios assistenciais de prestação continuada, inclusive liquidação de passivo previdenciário, e despesas orçamentária associadas a programas de relevante interesse econômico e social.

$\S 1^{\circ}$ Ao Fundo criado por este artigo não se aplica o disposto na parte final do inciso II do $\S$ $9^{\circ}$ do art. 165 da Constituição.

$\S 2^{\circ}$ O Fundo criado por este artigo passa a ser denominado Fundo de Estabilização Fiscal a partir do início do exercício financeiro de 1996.

$\S 3^{\circ} \mathrm{O}$ Poder Executivo publicará demonstrativo da execução orçamentária, de periodicidade bimestral, no qual se discriminarão as fontes e usos do Fundo criado por este artigo."

Art. $2^{\circ} \mathrm{O}$ artigo 72 do Ato das Disposições Constitucionais Transitórias passa a vigorar com a seguinte redação:

“Art. 72. Integram o Fundo Social de Emergência:

I -

II - a parcela do produto da arrecadação do imposto sobre renda e proventos de qualquer natureza e do imposto sobre operações de crédito, câmbio e seguro, ou relativas a títulos e valores 
mobiliários, decorrente das alterações produzidas pela Lei $\mathrm{n}^{\circ}$ 8.894, de 21 de junho de 1994, e pelas Leis n ${ }^{\circ}$ s 8.849 e 8.848, ambas de 28 de janeiro de 1994, e modificações posteriores;

III - a parcela do produto da arrecadação resultante da elevação da alíquota da contribuição social sobre o lucro dos contribuintes a que se refere o $\S 1^{\circ}$ do $\operatorname{artigo} 22$ da Lei $n^{\circ} 8.212$, de 24 de julho de 1991, a qual, nos exercícios financeiros de 1994 e 1995, bem assim no período de $1^{\circ}$ de janeiro de 1996 a 30 de junho de 1997, passa a ser de 30\%, sujeita a alteração por lei ordinária, mantidas as demais normas da Lei $\mathrm{n}^{\circ} \mathbf{7 . 6 8 9}$, de 15 de dezembro de 1988;

IV - vinte por cento do produto da arrecadação de todos os impostos e contribuições da União, já instituídos ou a serem criados, excetuado o previsto nos incisos I, II e III, observado o disposto $\operatorname{nos} \S \S 3^{\circ}$ e $4^{\circ}$;

$\mathrm{V}$ - a parcela do produto da arrecadação da contribuição de que trata a Lei Complementar $n^{\circ}$ 7, de 7 de setembro de 1970, devida pelas pessoas jurídicas a que se refere o inciso III deste artigo, a qual será calculada, nos exercícios financeiros de 1994 e 1995, bem assim no período de $1^{\circ}$ de janeiro de 1996 a 30 de junho de 1997, mediante a aplicação da alíquota de setenta e cinco centésimos por cento, sujeita a alteração por lei ordinária, sobre a receita bruta operacional, como definida na legislação do imposto sobre renda e proventos de qualquer natureza; e

VI -

$\S 1^{\circ}$

$\S 2^{\circ}$ As parcelas de que tratam os incisos I, II, III e V serão previamente deduzidas da base de cálculo de qualquer vinculação ou participação constitucional ou legal, não se lhes aplicando o disposto nos artigos 159, 212 e 239 da Constituição.

$\S 3^{\circ}$ A parcela de que trata o inciso IV será previamente deduzida da base de cálculo das vinculações ou participações constitucionais previstas nos artigos 153, § 5, 157 , II, 212 e 239 da Constituição.

$\S 4^{\circ} \mathrm{O}$ disposto no parágrafo anterior não se aplica aos recursos previstos nos artigos 158 , II, 159 da Constituição. 
$\S 5^{\circ}$ A parcela dos recursos provenientes do imposto sobre renda e proventos de qualquer natureza, destinada ao Fundo Social de Emergência, nos termos do inciso II deste artigo, não poderá exceder a cinco inteiros e seis décimos por cento do total do produto da sua arrecadação."

Art. $3^{\circ}$ Esta Emenda Constitucional entra em vigor na data de sua publicação.

Brasília, 4 de março de 1996.

\begin{tabular}{|c|c|}
\hline$\underline{\text { Mesa da Câmara dos Deputados }}$ & $\underline{\text { Mesa do Senado Federal }}$ \\
\hline Deputado LUÍS EDUARDO & Senador JOSÉ SARNEY \\
\hline Presidente & Presidente \\
\hline Deputado RONALDO PERIM & Senador TEOTÔNIO VILELA FILHO \\
\hline $1^{\circ}$ Vice-Presidente & $1^{\circ}$ Vice-Presidente \\
\hline Deputado BETO MANSUR & Senador JÚLIO CAMPOS \\
\hline $2^{\circ}$ Vice-Presidente & $2^{\circ}$ Vice-Presidente \\
\hline Deputado WILSON CAMPOS & Senador ODACIR SOARES \\
\hline $1^{\circ}$ Secretário & $1^{\circ}$ Secretário \\
\hline
\end{tabular}

Deputado LEOPOLDO BESSONE Senador RENAN CALHEIROS

$2^{\circ}$ Secretário $\quad 2^{\circ}$ Secretário

Deputado BENEDITO DOMINGOS Senador LEVY DIAS

$3^{\circ}$ Secretário $\quad 3^{\circ}$ Secretário

Deputado JOÃO HENRIQUE Senador ERNANDES AMORIM

$4^{\circ}$ Secretário $\quad 4^{\circ}$ Secretário 


\section{EMENDA CONSTITUCIONAL N 17 - 1997}

Altera dispositivos dos artigos 71 e 72 do Ato das Disposições Constitucionais Transitórias, introduzidos pela Emenda Constitucional de Revisão nº 1, de 1994.

As Mesas da Câmara dos Deputados e do Senado Federal, nos termos do $\S 3^{\circ}$ do artigo 60 da Constituição Federal, promulgam a seguinte Emenda ao texto constitucional:

Art. $1^{\circ} \mathrm{O}$ caput do artigo 71 do Ato das Disposições Constitucionais Transitórias passa a vigorar com a seguinte redação:

“Art. 71. É Instituído, nos exercícios financeiros de 1994 e 1995, bem assim nos períodos de $1^{\circ}$ de janeiro de 1996 a 30 de junho de 1997 e $1^{\circ}$ de julho de 1997 a 31 de dezembro de 1999, o Fundo Social de Emergência, com o objetivo de saneamento financeiro da Fazenda Pública Federal e de estabilização econômica, cujos recursos serão aplicados prioritariamente no custeio das ações dos sistemas de saúde e educação, incluindo a complementação de recursos de que trata o $\S 3^{\circ}$ do artigo 60 do Ato das Disposições Constitucionais Transitórias, benefícios previdenciários e auxílios assistenciais de prestação continuada, inclusive liquidação de passivo previdenciário, e despesas orçamentárias associadas a programas de relevante interesse econômico social.

Art. $2^{\circ}$ inciso V do artigo 72 do Ato das Disposições Constitucionais Transitórias passa a vigorar com a seguinte redação:

"V - a parcela do produto da arrecadação da contribuição de que trata a Lei Complementar $\mathrm{n}^{\circ} 7$, de 7 de setembro de 1970, devida pelas pessoas jurídicas a que se refere o inciso III deste artigo, a qual será calculada, nos exercícios financeiros de 1994 a 1995, bem assim nos períodos de $1^{\circ}$ de janeiro de 1996 a 30 de junho de 1997 e de $1^{\circ}$ de julho de 1997 a 31 de dezembro de 1999, mediante a aplicação da alíquota de setenta e cinco centésimos por cento, sujeita a alteração por lei ordinária posterior, sobre a receita bruta operacional, como definida na legislação do imposto sobre renda e proventos de qualquer natureza;"

Art. $3^{\circ}$ A União repassará aos Municípios, do produto da arrecadação do Imposto sobre a Renda e Proventos de Qualquer Natureza, tal como considerado na constituição dos fundos de que trata o artigo 159, I, da Constituição, excluída a parcela referida no artigo 72, I, do Ato das Disposições Constitucionais Transitórias, os seguintes percentuais: 
I - um inteiro e cinqüenta e seis centésimos por cento, no período de $1^{\text {o }}$ de julho de 1997 a 31 de dezembro de 1997;

II - um inteiro e oitocentos e setenta e cinco milésimos por cento, no período de $1^{\circ}$ de janeiro de 1998 a 31 de dezembro de 1998;

III - dois inteiros e cinco décimos por cento, no período de $1^{\circ}$ de janeiro de 1999 a 31 de dezembro de 1999.

Parágrafo único. O repasse dos recursos de que trata este artigo obedecerá à mesma periodicidade e aos mesmos critérios de repartição e normas adotadas no Fundo de Participação dos Municípios, observado o disposto no artigo 160 da Constituição.

Art. $4^{\circ}$ Os efeitos do disposto nos artigos 71 e 72 do Ato das Disposições Constitucionais Transitórias, com a redação dada pelos artigos $1^{\circ}$ e $2^{\circ}$ desta Emenda, são retroativos a $1^{\circ}$ de julho de 1997.

Parágrafo único. As parcelas de recursos destinados ao Fundo de Estabilização Fiscal e entregues na forma do artigo 159, I, da Constituição, no período compreendido entre $1^{\circ}$ de julho de 1997 e a data de promulgação desta Emenda, serão deduzidas das cotas subseqüentes, limitada a dedução a um décimo do valor total entregue em cada mês.

Art. $5^{\circ}$ Observado o disposto no artigo anterior, a União aplicará as disposições do artigo $3^{\circ}$ desta emenda retroativamente a $1^{\circ}$ de julho de 1997.

Art. $6^{\circ}$ Esta Emenda Constitucional entra em vigor na data de sua publicação.

Brasília, 22 de novembro de 1997.

$\underline{\text { Mesa da Câmara dos Deputados }}$

Deputado MICHEL TEMER

Presidente

Deputado HERÁCLITO FORTES $\underline{\text { Mesa do Senado Federal }}$

Senador ANTONIO CARLOS MA-

\section{GALHÃES}

Presidente

Senador GERALDO MELO 
$1^{\mathrm{o}}$ Vice-Presidente

Deputado

CAVALCANTI

$2^{\circ}$ Vice-Presidente

Deputado UBIRATAN AGUIAR

$1^{\circ}$ Secretário

Deputado NELSON TRAD

$2^{\circ}$ Secretário

Deputado PAULO PAIM

$3^{\circ}$ Secretário

Deputado EFRAIM MORAIS $1^{\mathrm{o}}$ Vice-Presidente

Senadora JÚNIA MARISE

$2^{\circ}$ Vice-Presidente

Senador RONALDO CUNHA LIMA

$1^{\circ}$ Secretário

Senador CARLOS PATROCÍNIO

$2^{\circ}$ Secretário

Senador FLAVIANO MELO

\section{EMENDA CONSTITUCIONAL No $27-2000$}

Acrescenta o artigo 76 ao ato das Disposições Constitucionais Transitórias, instituindo a desvinculação de arrecadação de impostos e contribuições sociais da União.

As Mesas da Câmara dos Deputados e do Senado Federal, nos termos do $\S 3^{0}$ do artigo 60 da Constituição Federal, promulgam a seguinte Emenda ao texto constitucional:

Art. $1^{\text {o }}$ É incluído o artigo 76 ao Ato das Disposições Constitucionais Transitórias, com a seguinte redação:

“Art. 76. É desvinculado de órgão, fundo ou despesa, no período de 2000 a 2003, vinte por cento da arrecadação de impostos e contribuições sociais da União, já instituídos ou que vierem a ser criados no referido período, seus adicionais e respectivos acréscimos legais.

"§ $1^{0}$ O disposto no caput deste artigo não reduzirá a base de cálculo das transferências a Estados, Distrito Federal e Municípios na forma dos artigos 153, § 
$5^{\circ}$; 157, I; 158, I e II; e 159, I, "a" e "b", e II, da Constituição, bem como a base de cálculo das aplicações em programas de financiamento ao setor produtivo das regiões Norte, Nordeste e Centro-Oeste a que se refere o artigo 159, I, "c", da Constituição.

"§ $2^{\underline{0}}$ Excetua-se da desvinculação de que trata o caput deste artigo a arrecadação da contribuição social do salário-educação a que se refere o artigo $212, \S 5^{\circ}$, da Constituição."

Art. $2^{-}$Esta Emenda Constitucional entra em vigor na data de sua publicação.

Brasília, 21 de março de 2000.

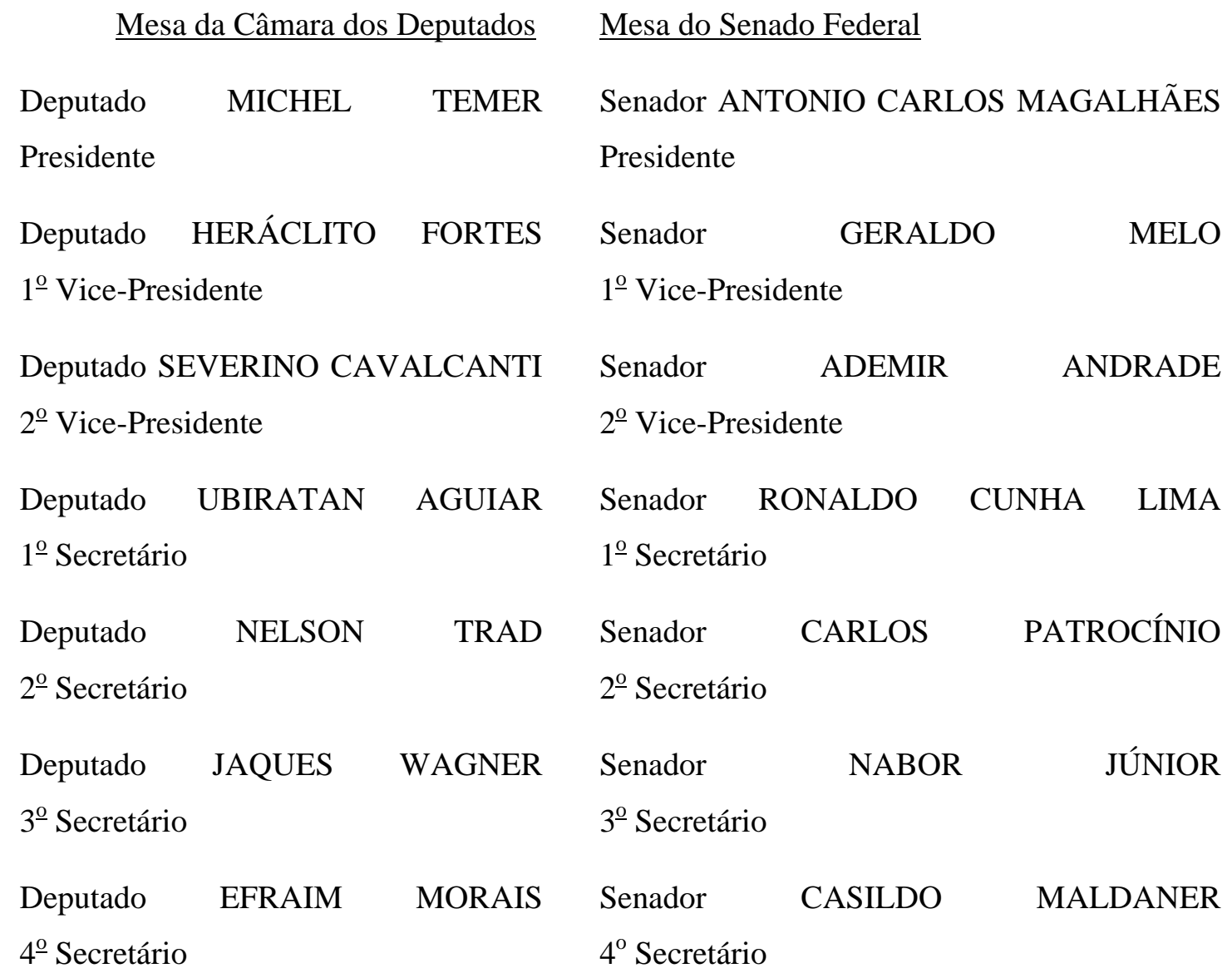

Este texto não substitui o publicado no Diário Oficial da União de 22 de março de 2000.

3 - Senado Federal do Brasil: Legislaturas $50^{\mathrm{a}}$ e $51^{\mathrm{a}}$ (1995-2003). 
Para todas as tabelas o pertencimento à Coalizão I e II significa fazer parte das duas formadas no governo. Se apenas aparece Coalizão II, é porque passou a integrar o apoio ao governo em um segundo momento da coalizão. A fonte de identificação da formação das coalizões está em Figueiredo, 2006.

GOVERNO FERNANDO HENRIQUE CARDOSO I (1995-1998)

SENADORES TITULARES na 50ª LEGISLATURA (1995-1999) - por partido.

\begin{tabular}{|l|c|c|c|c|}
\hline NOME & PARTIDO & POSIÇÃO & ESTADO & REGIÃO \\
\hline Coutinho Jorge & PSDB & Coalizão I e II & PA & NO \\
\hline Romero Jucá & PSDB & Coalizão I e II & RR & NO \\
\hline Teotônio Vilela Filho & PSDB & Coalizão I e II & AL & NE \\
\hline Beni Veras & PSDB & Coalizão I e II & CE & NE \\
\hline Lúcio Alcântara & PSDB & Coalizão I e II & CE & NE \\
\hline Ronaldo Cunha Lima & PSDB & Coalizão I e II & PB & NE \\
\hline Freitas Neto & PSDB & Coalizão I e II & PI & NE \\
\hline Geraldo Melo & PSDB & Coalizão I e II & RN & NE \\
\hline Albano Franco & PSDB & Coalizão I e II & SE & NE \\
\hline José Roberto Arruda & PSDB & Coalizão I e II & DF & CO \\
\hline Lúdio Coelho & PSDB & Coalizão I e II & MS & CO \\
\hline José Ignácio Ferreira & PSDB & Coalizão I e II & ES & SE \\
\hline Artur da Távola & PSDB & Coalizão I e II & RJ & SE \\
\hline José Serra & PSDB & Coalizão I e II & SP & SE \\
\hline Bernardo Cabral & PFL & Coalizão I e II & AM & NO \\
\hline José Bianco & PFL & Coalizão I e II & RO & NO \\
\hline João Rocha & PFL & Coalizão I e II & TO & NO \\
\hline Leomar Quintanilha & PFL & Coalizão I e II & TO & NO \\
\hline Guilherme Palmeira & PFL & Coalizão I e II & AL & NE \\
\hline Antônio Carlos Magalhães & PFL & Coalizão I e II & BA & NE \\
\hline Josaphat Marinho & PFL & Coalizão I e II & BA & NE \\
\hline Waldeck Ornellas & PFL & Coalizão I e II & BA & NE \\
\hline Alexandre Costa & Coalizão I e II & MA & NE \\
\hline
\end{tabular}




\begin{tabular}{|c|c|c|c|c|}
\hline Edison Lobão & PFL & Coalizão I e II & MA & $\mathrm{NE}$ \\
\hline Marco Maciel & PFL & Coalizão I e II & $\mathrm{PE}$ & NE \\
\hline Hugo Napoleão & PFL & Coalizão I e II & PI & $\mathrm{NE}$ \\
\hline José Agripino Maia & PFL & Coalizão I e II & $\mathrm{RN}$ & $\mathrm{NE}$ \\
\hline Jonas Pinheiro & PFL & Coalizão I e II & MT & $\mathrm{CO}$ \\
\hline Júlio Campos & PFL & Coalizão I e II & MT & $\mathrm{CO}$ \\
\hline Elcio Álvares & PFL & Coalizão I e II & $\mathrm{ES}$ & SE \\
\hline Francelino Pereira & PFL & Coalizão I e II & MG & SE \\
\hline Romeu Tuma & PFL & Coalizão I e II & SP & SE \\
\hline Vilson Kleinübing & PFL & Coalizão I e II & $\mathrm{SC}$ & SU \\
\hline Flaviano Melo & PMDB & Coalizão I e II & $\mathrm{AC}$ & $\mathrm{NO}$ \\
\hline Nabor Júnior & PMDB & Coalizão I e II & $\mathrm{AC}$ & $\mathrm{NO}$ \\
\hline Gilvam Borges & PMDB & Coalizão I e II & AP & $\mathrm{NO}$ \\
\hline José Sarney & PMDB & Coalizão I e II & AP & $\mathrm{NO}$ \\
\hline Jader Barbalho & PMDB & Coalizão I e II & PA & $\mathrm{NO}$ \\
\hline Marluce Pinto & PMDB & Coalizão I e II & $\mathrm{RR}$ & NO \\
\hline Renan Calheiros & PMDB & Coalizão I e II & $\mathrm{AL}$ & $\mathrm{NE}$ \\
\hline Sérgio Machado & PMDB & Coalizão I e II & $\mathrm{CE}$ & $\mathrm{NE}$ \\
\hline Antonio Mariz & PMDB & Coalizão I e II & PB & $\mathrm{NE}$ \\
\hline Humberto Lucena & PMDB & Coalizão I e II & PB & $\mathrm{NE}$ \\
\hline Iris Resende & PMDB & Coalizão I e II & $\mathrm{GO}$ & $\mathrm{CO}$ \\
\hline Mauro Miranda & PMDB & Coalizão I e II & GO & $\mathrm{CO}$ \\
\hline Onofre Quinan & PMDB & Coalizão I e II & GO & $\mathrm{CO}$ \\
\hline Ramez Tebet & PMDB & Coalizão I e II & MS & $\mathrm{CO}$ \\
\hline Carlos Bezerra & PMDB & Coalizão I e II & MT & $\mathrm{CO}$ \\
\hline Gerson Camata & PMDB & Coalizão I e II & $\mathrm{ES}$ & SE \\
\hline Roberto Requião & PMDB & Coalizão I e II & PR & SU \\
\hline Pedro Simon & PMDB & Coalizão I e II & $\mathrm{RS}$ & SU \\
\hline Casildo Maldaner & PMDB & Coalizão I e II & $\mathrm{SC}$ & SU \\
\hline Carlos Patrocínio & PTB & Coalizão I e II & TO & $\mathrm{NO}$ \\
\hline Carlos Wilson & PTB & Coalizão I e II & $\mathrm{PE}$ & $\mathrm{NE}$ \\
\hline Valmir Campelo & РTB & Coalizão I e II & DF & $\mathrm{CO}$ \\
\hline Arlindo Porto & РTB & Coalizão I e II & MG & SE \\
\hline
\end{tabular}




\begin{tabular}{|c|c|c|c|c|}
\hline José Eduardo & PTB & Coalizão I e II & PR & SU \\
\hline Ernandes Amorim & PPB & Coalizão II & RO & NO \\
\hline Hélio Campos & PPB & Coalizão II & RR & NO \\
\hline Epitácio Cafeteira & PPB & Coalizão II & MA & $\mathrm{NE}$ \\
\hline Lucídio Portella & PPB & Coalizão II & PI & $\mathrm{NE}$ \\
\hline Levy Dias & PPB & Coalizão II & MS & $\mathrm{CO}$ \\
\hline Espiridião Amin & PPB & Coalizão II & $\mathrm{SC}$ & SU \\
\hline Ademir Andrade & PSB & Oposição & PA & $\mathrm{NO}$ \\
\hline Antonio Carlos Valadares & PSB & Oposição & $\mathrm{SE}$ & $\mathrm{NE}$ \\
\hline Amazonino Mendes & PDC & Oposição & $\mathrm{AM}$ & $\mathrm{NO}$ \\
\hline Marina Silva & PT & Oposição & $\mathrm{AC}$ & NO \\
\hline José Eduardo Dutra & PT & Oposição & $\mathrm{SE}$ & $\mathrm{NE}$ \\
\hline Benedita da Silva & PT & Oposição & RJ & SE \\
\hline Eduardo Suplicy & PT & Oposição & SP & SE \\
\hline Emília Fernandes & PT & Oposição & $\mathrm{RS}$ & SU \\
\hline Jefferson Peres & PDT & Oposição & $\mathrm{AM}$ & $\mathrm{NO}$ \\
\hline Sebastião Rocha & PDT & Oposição & AP & $\mathrm{NO}$ \\
\hline Lauro Campos & PDT & Oposição & $\mathrm{DF}$ & $\mathrm{CO}$ \\
\hline Junia Marise & PDT & Oposição & MG & SE \\
\hline Darcy Ribeiro & PDT & Oposição & $\mathrm{RJ}$ & SE \\
\hline Osmar Dias & PDT & Oposição & PR & SU \\
\hline Roberto Freire & PPS & Oposição & $\mathrm{PE}$ & $\mathrm{NE}$ \\
\hline José Fogaça & PPS & Oposição & $\mathrm{RS}$ & $\mathrm{SU}$ \\
\hline Garibaldi Alves Filho & Sem registro & Indefinido & $\mathrm{RN}$ & $\mathrm{NE}$ \\
\hline
\end{tabular}

SENADORES EX-SUPLENTES na 50 ${ }^{\mathrm{a}}$ LEGISLATURA - por partido.

\begin{tabular}{|l|c|c|c|c|}
\hline NOME & PARTIDO & POSIÇÃO & ESTADO & REGIÃO \\
\hline Chico Sartori & PSDB & Coalizão I e II & RO & NO \\
\hline Geraldo Lessa & PSDB & Coalizão I e II & AL & NE \\
\hline Luiz Girão & PSDB & Coalizão I e II & CE & NE \\
\hline Reginaldo Duarte & PSDB & Coalizão I e II & CE & NE \\
\hline
\end{tabular}




\begin{tabular}{|c|c|c|c|c|}
\hline Luzia Toledo & PSDB & Coalizão I e II & ES & SE \\
\hline Nilo Teixeira Campos & PSDB & Coalizão I e II & RJ & SE \\
\hline Ricardo Santos & PSDB & Coalizão I e II & ES & SE \\
\hline Pedro Piva & PSDB & Coalizão I e II & SP & SE \\
\hline Gilberto Miranda & PFL & Coalizão I e II & $\mathrm{AM}$ & $\mathrm{NO}$ \\
\hline Moreira Mendes & PFL & Coalizão I e II & RO & $\mathrm{NO}$ \\
\hline Antonio Carlos Junior & PFL & Coalizão I e II & BA & $\mathrm{NE}$ \\
\hline Djalma Bessa & PFL & Coalizão I e II & BA & $\mathrm{NE}$ \\
\hline Francisco Benjamim & PFL & Coalizão I e II & BA & $\mathrm{NE}$ \\
\hline Bello Parga & PFL & Coalizão I e II & MA & $\mathrm{NE}$ \\
\hline Joel de Hollanda & PFL & Coalizão I e II & $\mathrm{PE}$ & $\mathrm{NE}$ \\
\hline José Alves & PFL & Coalizão I e II & $\mathrm{SE}$ & $\mathrm{NE}$ \\
\hline Leonel Paiva & PFL & Coalizão I e II & DF & $\mathrm{CO}$ \\
\hline Lindberg Cury & PFL & Coalizão I e II & $\mathrm{DF}$ & $\mathrm{CO}$ \\
\hline Zanete Cardinal & PFL & Coalizão I e II & MT & $\mathrm{CO}$ \\
\hline Jonice Tristão & PFL & Coalizão I e II & ES & SE \\
\hline Adir Gentil & PFL & Coalizão I e II & $\mathrm{SC}$ & $\mathrm{SU}$ \\
\hline Geraldo Althoff & PFL & Coalizão I e II & $\mathrm{SC}$ & $\mathrm{SU}$ \\
\hline Paulo Guerra & PMDB & Coalizão I e II & AP & $\mathrm{NO}$ \\
\hline Fernando Ribeiro & PMDB & Coalizão I e II & PA & $\mathrm{NO}$ \\
\hline Juvêncio Dias & PMDB & Coalizão I e II & PA & $\mathrm{NO}$ \\
\hline Alcides Falcão & PMDB & Coalizão I e II & $\mathrm{AL}$ & $\mathrm{NE}$ \\
\hline Djalma Falcão & PMDB & Coalizão I e II & $\mathrm{AL}$ & $\mathrm{NE}$ \\
\hline Francisco Escórcio & PMDB & Coalizão I e II & MA & $\mathrm{NE}$ \\
\hline Ney Suassuna & PMDB & Coalizão I e II & $\mathrm{PB}$ & $\mathrm{NE}$ \\
\hline Silva Júnior & PMDB & Coalizão I e II & $\mathrm{PB}$ & $\mathrm{NE}$ \\
\hline Fernando Bezerra & PMDB & Coalizão I e II & RN & $\mathrm{NE}$ \\
\hline Albino Boaventura & PMDB & Coalizão I e II & GO & $\mathrm{CO}$ \\
\hline José Saad & PMDB & Coalizão I e II & GO & $\mathrm{CO}$ \\
\hline Otoniel Machado & PMDB & Coalizão I e II & GO & $\mathrm{CO}$ \\
\hline Pedro Ubirajara & PMDB & Coalizão I e II & MS & $\mathrm{CO}$ \\
\hline Luiz Pastore & PMDB & Coalizão I e II & $\mathrm{ES}$ & $\mathrm{SE}$ \\
\hline Nivaldo Krüger & PMDB & Coalizão I e II & PR & $\mathrm{SU}$ \\
\hline
\end{tabular}




\begin{tabular}{|c|c|c|c|c|}
\hline Henrique Loyola & PMDB & Coalizão I e II & $\mathrm{SC}$ & SU \\
\hline Clodoaldo Torres & PTB & Coalizão I e II & PE & $\mathrm{NE}$ \\
\hline Wellington Roberto & PTB & Coalizão I e II & PB & $\mathrm{NE}$ \\
\hline Regina Assumpção & PTB & Coalizão I e II & MG & $\mathrm{SE}$ \\
\hline Luís Alberto de Oliveira & РTB & Coalizão I e II & PR & SU \\
\hline Edir Domeneguini & РTB & Coalizão I e II & $\mathrm{RS}$ & SU \\
\hline Fernando Matusalém & PPB & Coalizão II & RO & $\mathrm{NO}$ \\
\hline João França & PPB & Coalizão II & RR & $\mathrm{NO}$ \\
\hline Benício Sampaio & PPB & Coalizão II & PI & $\mathrm{NE}$ \\
\hline Elói Portela & PPB & Coalizão II & PI & $\mathrm{NE}$ \\
\hline José Bonifácio & PPB & Coalizão II & TO & $\mathrm{CO}$ \\
\hline Totó Cavalcante & PPB & Coalizão II & TO & $\mathrm{CO}$ \\
\hline Sandra Guidi & PPB & Coalizão II & $\mathrm{SC}$ & SU \\
\hline Maria Benigna Jucá & PSB & Oposição & AP & NO \\
\hline Ulisses Riedel & PSB & Oposição & DF & $\mathrm{CO}$ \\
\hline Júlio Eduardo & PV & Oposição & $\mathrm{AC}$ & $\mathrm{NO}$ \\
\hline Valdiolanda Teófilo & $\mathrm{PT}$ & Oposição & $\mathrm{SE}$ & $\mathrm{NE}$ \\
\hline Geraldo Cândido & $\mathrm{PT}$ & Oposição & $\mathrm{RJ}$ & $\mathrm{SE}$ \\
\hline Abdias Nascimento & PDT & Oposição & RJ & $\mathrm{SE}$ \\
\hline Blairo Maggi & Sem partido & Indefinido & MT & $\mathrm{CO}$ \\
\hline Meira Lins & Sem registro & Indefinido & $\mathrm{PE}$ & $\mathrm{NE}$ \\
\hline
\end{tabular}

SENADORES TITULARES na 50ª LEGISLATURA (1995-1999) - por região.

\begin{tabular}{|l|c|c|c|c|}
\hline NOME & REGIÃO & ESTADO & PARTIDO & POSIÇÃO \\
\hline Flaviano Melo & NO & AC & PMDB & Coalizão I e II \\
\hline Nabor Júnior & NO & AC & PMDB & Coalizão I e II \\
\hline Marina Silva & NO & AC & PT & Oposição \\
\hline Bernardo Cabral & NO & AM & PFL & Coalizão I e II \\
\hline Amazonino Mendes & NO & AM & PDC & Oposição \\
\hline Jefferson Peres & NO & AM & PDT & Oposição \\
\hline Gilvam Borges & NO & AP & PMDB & Coalizão I e II \\
\hline José Sarney & NO & AP & PMDB & Coalizão I e II \\
\hline
\end{tabular}




\begin{tabular}{|c|c|c|c|c|}
\hline Sebastião Rocha & NO & AP & PDT & Oposição \\
\hline Coutinho Jorge & NO & PA & PSDB & Coalizão I e II \\
\hline Jader Barbalho & NO & PA & PMDB & Coalizão I e II \\
\hline Ademir Andrade & $\mathrm{NO}$ & PA & PSB & Oposição \\
\hline José Bianco & $\mathrm{NO}$ & RO & PFL & Coalizão I e II \\
\hline Odacir Soares & NO & RO & РTB & Coalizão I e II \\
\hline Ernandes Amorim & NO & RO & PPB & Coalizão II \\
\hline Romero Jucá & NO & RR & PSDB & Coalizão I e II \\
\hline Marluce Pinto & $\mathrm{NO}$ & RR & PMDB & Coalizão I e II \\
\hline Hélio Campos & $\mathrm{NO}$ & RR & PPB & Coalizão II \\
\hline João Rocha & $\mathrm{NO}$ & TO & PFL & Coalizão I e II \\
\hline Leomar Quintanilha & $\mathrm{NO}$ & TO & PFL & Coalizão I e II \\
\hline Carlos Patrocínio & $\mathrm{NO}$ & TO & РTB & Coalizão I e II \\
\hline Teotônio Vilela Filho & $\mathrm{NE}$ & $\mathrm{AL}$ & PSDB & Coalizão I e II \\
\hline Guilherme Palmeira & $\mathrm{NE}$ & $\mathrm{AL}$ & PFL & Coalizão I e II \\
\hline Renan Calheiros & $\mathrm{NE}$ & $\mathrm{AL}$ & PMDB & Coalizão I e II \\
\hline Antônio Carlos Magalhães & $\mathrm{NE}$ & BA & PFL & Coalizão I e II \\
\hline Josaphat Marinho & $\mathrm{NE}$ & BA & PFL & Coalizão I e II \\
\hline Waldeck Ornellas & $\mathrm{NE}$ & BA & PFL & Coalizão I e II \\
\hline Beni Veras & $\mathrm{NE}$ & $\mathrm{CE}$ & PSDB & Coalizão I e II \\
\hline Lúcio Alcântara & $\mathrm{NE}$ & $\mathrm{CE}$ & PSDB & Coalizão I e II \\
\hline Sérgio Machado & $\mathrm{NE}$ & $\mathrm{CE}$ & PMDB & Coalizão I e II \\
\hline Alexandre Costa & $\mathrm{NE}$ & MA & PFL & Coalizão I e II \\
\hline Edison Lobão & $\mathrm{NE}$ & MA & PFL & Coalizão I e II \\
\hline Epitácio Cafeteira & $\mathrm{NE}$ & MA & PPB & Coalizão II \\
\hline Ronaldo Cunha Lima & $\mathrm{NE}$ & $\mathrm{PB}$ & PSDB & Coalizão I e II \\
\hline Antonio Mariz & $\mathrm{NE}$ & PB & PMDB & Coalizão I e II \\
\hline Humberto Lucena & $\mathrm{NE}$ & PB & PMDB & Coalizão I e II \\
\hline Marco Maciel & $\mathrm{NE}$ & $\mathrm{PE}$ & PFL & Coalizão I e II \\
\hline Carlos Wilson & $\mathrm{NE}$ & $\mathrm{PE}$ & PTB & Coalizão I e II \\
\hline Roberto Freire & $\mathrm{NE}$ & PE & PPS & Oposição \\
\hline Freitas Neto & $\mathrm{NE}$ & PI & PSDB & Coalizão I e II \\
\hline Hugo Napoleão & $\mathrm{NE}$ & PI & PFL & Coalizão I e II \\
\hline
\end{tabular}




\begin{tabular}{|c|c|c|c|c|}
\hline Lucídio Portella & $\mathrm{NE}$ & PI & PPB & Coalizão II \\
\hline Geraldo Melo & $\mathrm{NE}$ & $\mathrm{RN}$ & PSDB & Coalizão I e II \\
\hline José Agripino Maia & $\mathrm{NE}$ & RN & PFL & Coalizão I e II \\
\hline Garibaldi Alves Filho & $\mathrm{NE}$ & $\mathrm{RN}$ & Sem registro & Indefinido \\
\hline Albano Franco & $\mathrm{NE}$ & SE & PSDB & Coalizão I e II \\
\hline Antonio Carlos Valadares & $\mathrm{NE}$ & SE & PSB & Oposição \\
\hline José Eduardo Dutra & $\mathrm{NE}$ & SE & $\mathrm{PT}$ & Oposição \\
\hline José Roberto Arruda & $\mathrm{CO}$ & $\mathrm{DF}$ & PSDB & Coalizão I e II \\
\hline Valmir Campelo & $\mathrm{CO}$ & $\mathrm{DF}$ & PTB & Coalizão I e II \\
\hline Lauro Campos & $\mathrm{CO}$ & DF & PDT & Oposição \\
\hline Iris Resende & $\mathrm{CO}$ & GO & PMDB & Coalizão I e II \\
\hline Mauro Miranda & $\mathrm{CO}$ & GO & PMDB & Coalizão I e II \\
\hline Onofre Quinan & $\mathrm{CO}$ & GO & PMDB & Coalizão I e II \\
\hline Lúdio Coelho & $\mathrm{CO}$ & MS & PSDB & Coalizão I e II \\
\hline Ramez Tebet & $\mathrm{CO}$ & MS & PMDB & Coalizão I e II \\
\hline Levy Dias & $\mathrm{CO}$ & MS & PPB & Coalizão II \\
\hline Jonas Pinheiro & $\mathrm{CO}$ & MT & PFL & Coalizão I e II \\
\hline Júlio Campos & $\mathrm{CO}$ & MT & PFL & Coalizão I e II \\
\hline Carlos Bezerra & $\mathrm{CO}$ & MT & PMDB & Coalizão I e II \\
\hline José Ignácio Ferreira & $\mathrm{SE}$ & ES & PSDB & Coalizão I e II \\
\hline Elcio Álvares & $\mathrm{SE}$ & $\mathrm{ES}$ & PFL & Coalizão I e II \\
\hline Gerson Camata & $\mathrm{SE}$ & $\mathrm{ES}$ & PMDB & Coalizão I e II \\
\hline Francelino Pereira & $\mathrm{SE}$ & MG & PFL & Coalizão I e II \\
\hline Arlindo Porto & $\mathrm{SE}$ & MG & РTB & Coalizão I e II \\
\hline Junia Marise & $\mathrm{SE}$ & MG & PDT & Oposição \\
\hline Artur da Távola & $\mathrm{SE}$ & RJ & PSDB & Coalizão I e II \\
\hline Benedita da Silva & $\mathrm{SE}$ & $\mathrm{RJ}$ & PT & Oposição \\
\hline Darcy Ribeiro & $\mathrm{SE}$ & RJ & PDT & Oposição \\
\hline José Serra & $\mathrm{SE}$ & SP & PSDB & Coalizão I e II \\
\hline Romeu Tuma & $\mathrm{SE}$ & SP & PFL & Coalizão I e II \\
\hline Eduardo Suplicy & $\mathrm{SE}$ & SP & PT & Oposição \\
\hline Roberto Requião & SU & PR & PMDB & Coalizão I e II \\
\hline José Eduardo & SU & PR & РTB & Coalizão I e II \\
\hline
\end{tabular}




\begin{tabular}{|l|c|c|c|c|}
\hline Osmar Dias & SU & PR & PDT & Oposição \\
\hline Pedro Simon & SU & RS & PMDB & Coalizão I e II \\
\hline Emília Fernandes & SU & RS & PT & Oposição \\
\hline José Fogaça & SU & RS & PPS & Oposição \\
\hline Vilson Kleinübing & SU & SC & PFL & Coalizão I e II \\
\hline Casildo Maldaner & SU & SC & PMDB & Coalizão I e II \\
\hline Espiridião Amin & SU & SC & PPB & Coalizão II \\
\hline
\end{tabular}

SENADORES EX-SUPLENTES na 50ª LEGISLATURA - por região.

\begin{tabular}{|l|c|c|c|c|}
\hline NOME & REGIÃO & ESTADO & PARTIDO & POSIÇÃO \\
\hline Júlio Eduardo & NO & AC & PV & Oposição \\
\hline Gilberto Miranda & NO & AM & PFL & Coalizão I e II \\
\hline Paulo Guerra & NO & AP & PMDB & Coalizão I e II \\
\hline Maria Benigna Jucá & NO & AP & PSB & Oposição \\
\hline Fernando Ribeiro & NO & PA & PMDB & Coalizão I e II \\
\hline Juvêncio Dias & NO & PA & PMDB & Coalizão I e II \\
\hline Chico Sartori & NO & RO & PSDB & Coalizão I e II \\
\hline Moreira Mendes & NO & RO & PFL & Coalizão I e II \\
\hline Fernando Matusalém & NO & RO & PPB & Coalizão II \\
\hline João França & NO & RR & PPB & Coalizão II \\
\hline José Bonifácio & NO & TO & PPB & Coalizão II \\
\hline Totó Cavalcante & NO & TO & PPB & Coalizão II \\
\hline Geraldo Lessa & NE & AL & PSDB & Coalizão I e II \\
\hline Alcides Falcão & NE & AL & PMDB & Coalizão I e II \\
\hline Djalma Falcão & NE & AL & PMDB & Coalizão I e II \\
\hline Antonio Carlos Junior & NE & BA & PFL & Coalizão I e II \\
\hline Djalma Bessa & NE & BA & PFL & Coalizão I e II \\
\hline Francisco Benjamim & NE & BA & PFL & Coalizão I e II \\
\hline Luiz Girão & NE & CE & PSDB & Coalizão I e II \\
\hline Reginaldo Duarte & NE & CE & PSDB & Coalizão I e II \\
\hline Bello Parga & NE & MA & PFL & Coalizão I e II \\
\hline
\end{tabular}




\begin{tabular}{|c|c|c|c|c|}
\hline Francisco Escórcio & $\mathrm{NE}$ & MA & PMDB & Coalizão I e II \\
\hline Ney Suassuna & $\mathrm{NE}$ & PB & PMDB & Coalizão I e II \\
\hline Silva Júnior & $\mathrm{NE}$ & PB & PMDB & Coalizão I e II \\
\hline Wellington Roberto & $\mathrm{NE}$ & PB & РTB & Coalizão I e II \\
\hline Clodoaldo Torres & $\mathrm{NE}$ & $\mathrm{PE}$ & РTB & Coalizão I e II \\
\hline Joel de Hollanda & $\mathrm{NE}$ & $\mathrm{PE}$ & PFL & Coalizão I e II \\
\hline Meira Lins & $\mathrm{NE}$ & $\mathrm{PE}$ & Sem registro & Indefinido \\
\hline Benício Sampaio & $\mathrm{NE}$ & PI & PPB & Coalizão II \\
\hline Elói Portela & $\mathrm{NE}$ & PI & PPB & Coalizão II \\
\hline Fernando Bezerra & $\mathrm{NE}$ & $\mathrm{RN}$ & PMDB & Coalizão I e II \\
\hline José Alves & $\mathrm{NE}$ & $\mathrm{SE}$ & PFL & Coalizão I e II \\
\hline Valdiolanda Teófilo & $\mathrm{NE}$ & $\mathrm{SE}$ & PT & Oposição \\
\hline Leonel Paiva & $\mathrm{CO}$ & $\mathrm{DF}$ & PFL & Coalizão I e II \\
\hline Lindberg Cury & $\mathrm{CO}$ & DF & PFL & Coalizão I e II \\
\hline Albino Boaventura & $\mathrm{CO}$ & GO & PMDB & Coalizão I e II \\
\hline José Saad & $\mathrm{CO}$ & GO & PMDB & Coalizão I e II \\
\hline Otoniel Machado & $\mathrm{CO}$ & $\mathrm{GO}$ & PMDB & Coalizão I e II \\
\hline Pedro Ubirajara & $\mathrm{CO}$ & MS & PMDB & Coalizão I e II \\
\hline Zanete Cardinal & $\mathrm{CO}$ & MT & PFL & Coalizão I e II \\
\hline Blairo Maggi & $\mathrm{CO}$ & MT & Sem partido & Indefinido \\
\hline Luzia Toledo & $\mathrm{SE}$ & $\mathrm{ES}$ & PSDB & Coalizão I e II \\
\hline Ricardo Santos & SE & $\mathrm{ES}$ & PSDB & Coalizão I e II \\
\hline Jonice Tristão & SE & ES & PFL & Coalizão I e II \\
\hline Luiz Pastore & SE & $\mathrm{ES}$ & PMDB & Coalizão I e II \\
\hline Regina Assumpção & $\mathrm{SE}$ & MG & PTB & Coalizão I e II \\
\hline Nilo Teixeira Campos & $\mathrm{SE}$ & RJ & PSDB & Coalizão I e II \\
\hline Geraldo Cândido & $\mathrm{SE}$ & RJ & PT & Oposição \\
\hline Abdias Nascimento & $\mathrm{SE}$ & RJ & PDT & Oposição \\
\hline Pedro Piva & $\mathrm{SE}$ & SP & PSDB & Coalizão I e II \\
\hline Nivaldo Krüger & SU & PR & PMDB & Coalizão I e II \\
\hline Luís Alberto de Oliveira & SU & PR & PTB & Coalizão I e II \\
\hline Edir Domeneguini & SU & $\mathrm{RS}$ & РTB & Coalizão I e II \\
\hline Adir Gentil & SU & $\mathrm{SC}$ & PFL & Coalizão I e II \\
\hline
\end{tabular}




\begin{tabular}{|l|c|c|c|c|}
\hline Geraldo Althoff & SU & SC & PFL & Coalizão I e II \\
\hline Henrique Loyola & SU & SC & PMDB & Coalizão I e II \\
\hline Sandra Guidi & SU & SC & PPB & Coalizão II \\
\hline
\end{tabular}

GOVERNO FERNANDO HENRIQUE CARDOSO II (1999-2002)

SENADORES TITULARES na 51 ${ }^{\text {a }}$ LEGISLATURA (1999-2003) - por partido.

\begin{tabular}{|l|c|c|c|c|}
\hline NOME & PARTIDO & POSIÇÃO & ESTADO & REGIÃO \\
\hline Romero Jucá & PSDB & Coalizão I e II & RR & NO \\
\hline Eduardo Siqueira Campos & PSDB & Coalizão I e II & TO & NO \\
\hline Teotônio Vilela Filho & PSDB & Coalizão I e II & AL & NE \\
\hline Lúcio Alcântara & PSDB & Coalizão I e II & CE & NE \\
\hline Luiz Pontes & PSDB & Coalizão I e II & CE & NE \\
\hline Ronaldo Cunha Lima & PSDB & Coalizão I e II & PB & NE \\
\hline Freitas Neto & PSDB & Coalizão I e II & PI & NE \\
\hline Geraldo Melo & PSDB & Coalizão I e II & RN & NE \\
\hline José Roberto Arruda & PSDB & Coalizão I e II & DF & CO \\
\hline Juvêncio da Fonseca & PSDB & Coalizão I e II & MS & CO \\
\hline Lúdio Coelho & PSDB & Coalizão I e II & MS & CO \\
\hline Antero Paes de Barros & PSDB & Coalizão I e II & MT & CO \\
\hline José Ignácio Ferreira & PSDB & Coalizão I e II & ES & SE \\
\hline Artur da Távola & PSDB & Coalizão I e II & RJ & SE \\
\hline José Serra & PSDB & Coalizão I e II & SP & SE \\
\hline Álvaro Dias & PSDB & Coalizão I e II & PR & SU \\
\hline Bernardo Cabral & PFL & Coalizão I e II & AM & NO \\
\hline José Bianco & PFL & Coalizão I e II & TO & NO \\
\hline Leomar Quintanilha & PFL & Coalizão I e II & BA & NE \\
\hline Antônio Carlos Magalhães & PFL & Coalizão I e II & BA & NE \\
\hline Paulo Souto & Coalizão I e II & BA & NE \\
\hline Waldeck Ornellas & Coalizão I e II & MA & NE \\
\hline Alexandre Costa & RO & NO \\
\hline
\end{tabular}




\begin{tabular}{|c|c|c|c|c|}
\hline Edison Lobão & PFL & Coalizão I e II & MA & $\mathrm{NE}$ \\
\hline José Jorge & PFL & Coalizão I e II & $\mathrm{PE}$ & $\mathrm{NE}$ \\
\hline Hugo Napoleão & PFL & Coalizão I e II & PI & $\mathrm{NE}$ \\
\hline José Agripino Maia & PFL & Coalizão I e II & $\mathrm{RN}$ & NE \\
\hline Maria do Carmo Alves & PFL & Coalizão I e II & $\mathrm{SE}$ & $\mathrm{NE}$ \\
\hline Jonas Pinheiro & PFL & Coalizão I e II & MT & $\mathrm{CO}$ \\
\hline Francelino Pereira & PFL & Coalizão I e II & MG & SE \\
\hline Romeu Tuma & PFL & Coalizão I e II & SP & SE \\
\hline Jorge Bornhausen & PFL & Coalizão I e II & $\mathrm{SC}$ & SU \\
\hline Vilson Kleinübing & PFL & Coalizão I e II & $\mathrm{SC}$ & SU \\
\hline Nabor Júnior & PMDB & Coalizão I e II & $\mathrm{AC}$ & NO \\
\hline Gilberto Mestrinho & PMDB & Coalizão I e II & $\mathrm{AM}$ & $\mathrm{NO}$ \\
\hline Gilvam Borges & PMDB & Coalizão I e II & AP & NO \\
\hline José Sarney & PMDB & Coalizão I e II & AP & NO \\
\hline Jader Barbalho & PMDB & Coalizão I e II & PA & NO \\
\hline Luiz Otávio & PMDB & Coalizão I e II & PA & NO \\
\hline Amir Lando & PMDB & Coalizão I e II & RO & NO \\
\hline Marluce Pinto & PMDB & Coalizão I e II & RR & NO \\
\hline Renan Calheiros & PMDB & Coalizão I e II & $\mathrm{AL}$ & $\mathrm{NE}$ \\
\hline Sérgio Machado & PMDB & Coalizão I e II & $\mathrm{CE}$ & $\mathrm{NE}$ \\
\hline João Alberto Souza & PMDB & Coalizão I e II & MA & $\mathrm{NE}$ \\
\hline Alberto Dias & PMDB & Coalizão I e II & PI & $\mathrm{NE}$ \\
\hline Humberto Lucena & PMDB & Coalizão I e II & PB & $\mathrm{NE}$ \\
\hline Ney Suassuna & PMDB & Coalizão I e II & PB & $\mathrm{NE}$ \\
\hline Luiz Estevão & PMDB & Coalizão I e II & DF & $\mathrm{CO}$ \\
\hline Iris Resende & PMDB & Coalizão I e II & GO & $\mathrm{CO}$ \\
\hline Maguito Vilela & PMDB & Coalizão I e II & GO & $\mathrm{CO}$ \\
\hline Mauro Miranda & PMDB & Coalizão I e II & GO & $\mathrm{CO}$ \\
\hline Ramez Tebet & PMDB & Coalizão I e II & MS & $\mathrm{CO}$ \\
\hline Carlos Bezerra & PMDB & Coalizão I e II & MT & $\mathrm{CO}$ \\
\hline Gerson Camata & PMDB & Coalizão I e II & $\mathrm{ES}$ & SE \\
\hline Roberto Requião & PMDB & Coalizão I e II & PR & SU \\
\hline Pedro Simon & PMDB & Coalizão I e II & $\mathrm{RS}$ & SU \\
\hline
\end{tabular}




\begin{tabular}{|c|c|c|c|c|}
\hline Casildo Maldaner & PMDB & Coalizão I e II & $\mathrm{SC}$ & SU \\
\hline Odacir Soares & PTB & Coalizão I e II & RO & $\mathrm{NO}$ \\
\hline Mozarildo Cavancanti & PTB & Coalizão I e II & RR & $\mathrm{NO}$ \\
\hline Carlos Patrocínio & PTB & Coalizão I e II & TO & $\mathrm{NO}$ \\
\hline Carlos Wilson & PTB & Coalizão I e II & $\mathrm{PE}$ & $\mathrm{NE}$ \\
\hline Fernando Bezerra & PTB & Coalizão I e II & $\mathrm{RN}$ & $\mathrm{NE}$ \\
\hline Arlindo Porto & PTB & Coalizão I e II & MG & SE \\
\hline José Alencar & PL & Coalizão II & MG & SE \\
\hline Ademir Andrade & PSB & Oposição & PA & NO \\
\hline Antonio Carlos Valadares & PSB & Oposição & $\mathrm{SE}$ & $\mathrm{NE}$ \\
\hline Paulo Hartung & PSB & Oposição & $\mathrm{ES}$ & SE \\
\hline Marina Silva & PT & Oposição & $\mathrm{AC}$ & NO \\
\hline Tião Viana & PT & Oposição & $\mathrm{AC}$ & $\mathrm{NO}$ \\
\hline Heloísa Helena & PT & Oposição & $\mathrm{AL}$ & $\mathrm{NE}$ \\
\hline José Eduardo Dutra & $\mathrm{PT}$ & Oposição & $\mathrm{SE}$ & $\mathrm{NE}$ \\
\hline Benedita da Silva & $\mathrm{PT}$ & Oposição & RJ & SE \\
\hline Roberto Saturnino & PT & Oposição & RJ & $\mathrm{SE}$ \\
\hline Eduardo Suplicy & PT & Oposição & SP & SE \\
\hline Emília Fernandes & $\mathrm{PT}$ & Oposição & $\mathrm{RS}$ & SU \\
\hline Jefferson Peres & PDT & Oposição & AM & $\mathrm{NO}$ \\
\hline Sebastião Rocha & PDT & Oposição & AP & $\mathrm{NO}$ \\
\hline Lauro Campos & PDT & Oposição & $\mathrm{DF}$ & $\mathrm{CO}$ \\
\hline Osmar Dias & PDT & Oposição & PR & SU \\
\hline Roberto Freire & PPS & Oposição & $\mathrm{PE}$ & $\mathrm{NE}$ \\
\hline José Fogaça & PPS & Oposição & $\mathrm{RS}$ & SU \\
\hline
\end{tabular}

SENADORES EX-SUPLENTES na 51 ${ }^{\text {a }}$ LEGISLATURA (1999-2003) - por partido.

\begin{tabular}{|l|c|c|c|c|}
\hline NOME & PARTIDO & POSIÇÃO & ESTADO & REGIÃO \\
\hline Chico Sartori & PSDB & Coalizão I e II & RO & NO \\
\hline Geraldo Lessa & PSDB & Coalizão I e II & AL & NE \\
\hline Luiz Girão & PSDB & Coalizão I e II & CE & NE \\
\hline Reginaldo Duarte & PSDB & Coalizão I e II & CE & NE \\
\hline
\end{tabular}




\begin{tabular}{|c|c|c|c|c|}
\hline João Batista Motta & PSDB & Coalizão I e II & $\mathrm{ES}$ & SE \\
\hline Luzia Toledo & PSDB & Coalizão I e II & ES & SE \\
\hline Ricardo Santos & PSDB & Coalizão I e II & ES & SE \\
\hline Nilo Teixeira Campos & PSDB & Coalizão I e II & RJ & SE \\
\hline Pedro Piva & PSDB & Coalizão I e II & SP & SE \\
\hline Olivir Gabardo & PSDB & Coalizão I e II & PR & $\mathrm{SU}$ \\
\hline Gilberto Miranda & PFL & Coalizão I e II & $\mathrm{AM}$ & $\mathrm{NO}$ \\
\hline Moreira Mendes & PFL & Coalizão I e II & RO & $\mathrm{NO}$ \\
\hline Antonio Carlos Júnior & PFL & Coalizão I e II & BA & $\mathrm{NE}$ \\
\hline Djalma Bessa & PFL & Coalizão I e II & BA & $\mathrm{NE}$ \\
\hline Rodolpho Tourinho & PFL & Coalizão I e II & BA & $\mathrm{NE}$ \\
\hline Bello Parga & PFL & Coalizão I e II & MA & $\mathrm{NE}$ \\
\hline José Coelho & PFL & Coalizão I e II & $\mathrm{PE}$ & $\mathrm{NE}$ \\
\hline Renildo Santana & PFL & Coalizão I e II & SE & $\mathrm{NE}$ \\
\hline Lindberg Cury & PFL & Coalizão I e II & DF & $\mathrm{CO}$ \\
\hline Geraldo Althoff & PFL & Coalizão I e II & $\mathrm{SC}$ & $\mathrm{SU}$ \\
\hline João Thomé Mestrinho & PMDB & Coalizão I e II & AM & $\mathrm{NO}$ \\
\hline Nova da Costa & PMDB & Coalizão I e II & AP & $\mathrm{NO}$ \\
\hline Fernando Ribeiro & PMDB & Coalizão I e II & PA & $\mathrm{NO}$ \\
\hline Mário Calixto & PMDB & Coalizão I e II & RO & $\mathrm{NO}$ \\
\hline Paulo Elifas & PMDB & Coalizão I e II & RO & $\mathrm{NO}$ \\
\hline Djalma Falcão & PMDB & Coalizão I e II & $\mathrm{AL}$ & $\mathrm{NE}$ \\
\hline Antônio Leite & PMDB & Coalizão I e II & MA & $\mathrm{NE}$ \\
\hline Francisco Escórcio & PMDB & Coalizão I e II & MA & $\mathrm{NE}$ \\
\hline Ribamar Fiquene & PMDB & Coalizão I e II & MA & $\mathrm{NE}$ \\
\hline Robinson Viana & PMDB & Coalizão I e II & $\mathrm{PB}$ & $\mathrm{NE}$ \\
\hline Silva Júnior & PMDB & Coalizão I e II & PB & $\mathrm{NE}$ \\
\hline Agnelo Alves & PMDB & Coalizão I e II & RN & $\mathrm{NE}$ \\
\hline Albino Boaventura & PMDB & Coalizão I e II & GO & $\mathrm{CO}$ \\
\hline Iris de Araújo & PMDB & Coalizão I e II & GO & $\mathrm{CO}$ \\
\hline Otoniel Machado & PMDB & Coalizão I e II & GO & $\mathrm{CO}$ \\
\hline Pedro Ubirajara & PMDB & Coalizão I e II & MS & $\mathrm{CO}$ \\
\hline Luiz Pastore & PMDB & Coalizão I e II & ES & SE \\
\hline
\end{tabular}




\begin{tabular}{|c|c|c|c|c|}
\hline Nivaldo Krüguer & PMDB & Coalizão I e II & PR & SU \\
\hline Henrique Loyola & PMDB & Coalizão I e II & $\mathrm{SC}$ & SU \\
\hline Wellington Roberto & PTB & Coalizão I e II & PB & $\mathrm{NE}$ \\
\hline Clodoaldo Torres & PTB & Coalizão I e II & $\mathrm{PE}$ & $\mathrm{NE}$ \\
\hline Tasso Rosado & PTB & Coalizão I e II & RN & $\mathrm{NE}$ \\
\hline Valmir Amaral & PTB & Coalizão I e II & DF & $\mathrm{CO}$ \\
\hline Regina Assumpção & PTB & Coalizão I e II & MG & SE \\
\hline Edir Domeneguini & PTB & Coalizão I e II & $\mathrm{RS}$ & $\mathrm{SU}$ \\
\hline Fernando Matusalém & PPB & Coalizão II & RO & $\mathrm{NO}$ \\
\hline José Bonifácio & PPB & Coalizão II & TO & $\mathrm{NO}$ \\
\hline Thelma Siqueira Campos & РPB & Coalizão II & TO & $\mathrm{NO}$ \\
\hline Totó Cavalcante & PPB & Coalizão II & TO & $\mathrm{NO}$ \\
\hline Benício Sampaio & PPB & Coalizão II & PI & $\mathrm{NE}$ \\
\hline Elói Portela & PPB & Coalizão II & PI & $\mathrm{NE}$ \\
\hline Ari Stadler & PPB & Coalizão II & $\mathrm{SC}$ & SU \\
\hline Vasco Furlan & PPB & Coalizão II & $\mathrm{SC}$ & SU \\
\hline Aelton Freitas & PL & Coalizão II & MG & SE \\
\hline Valdiolanda Teófilo & $\mathrm{PT}$ & Oposição & $\mathrm{SE}$ & $\mathrm{NE}$ \\
\hline Geraldo Cândido & $\mathrm{PT}$ & Oposição & $\mathrm{RJ}$ & SE \\
\hline Maria Benigna Jucá & PSB & Oposição & AP & $\mathrm{NO}$ \\
\hline Ulisses Riedel & PSB & Oposição & DF & $\mathrm{CO}$ \\
\hline Júlio Eduardo & PV & Oposição & $\mathrm{AC}$ & $\mathrm{NO}$ \\
\hline Blairo Maggi & Sem partido & Indefinido & MT & $\mathrm{CO}$ \\
\hline Luiz Soares & Sem partido & Indefinido & MT & $\mathrm{CO}$ \\
\hline Meira Lins & Sem registro & Indefinido & $\mathrm{PE}$ & $\mathrm{NE}$ \\
\hline
\end{tabular}

SENADORES TITULARES na 51 ${ }^{\text {a }}$ LEGISLATURA (1999-2003) - por região.

\begin{tabular}{|l|c|c|c|c|}
\hline NOME & REGIÃO & ESTADO & PARTIDO & POSIÇÃO \\
\hline Nabor Júnior & NO & AC & PMDB & Coalizão I e II \\
\hline Marina Silva & NO & AC & PT & Oposição \\
\hline Tião Viana & NO & AC & PT & Oposição \\
\hline Bernardo Cabral & NO & AM & PFL & Coalizão I e II \\
\hline
\end{tabular}




\begin{tabular}{|c|c|c|c|c|}
\hline Gilberto Mestrinho & $\mathrm{NO}$ & $\mathrm{AM}$ & PMDB & Coalizão I e II \\
\hline Jefferson Peres & NO & AM & PDT & Oposição \\
\hline Gilvam Borges & $\mathrm{NO}$ & $\mathrm{AP}$ & PMDB & Coalizão I e II \\
\hline José Sarney & $\mathrm{NO}$ & AP & PMDB & Coalizão I e II \\
\hline Sebastião Rocha & NO & AP & PDT & Oposição \\
\hline Jader Barbalho & $\mathrm{NO}$ & PA & PMDB & Coalizão I e II \\
\hline Luiz Otávio & $\mathrm{NO}$ & PA & PMDB & Coalizão I e II \\
\hline Ademir Andrade & NO & PA & PSB & Oposição \\
\hline José Bianco & $\mathrm{NO}$ & RO & PFL & Coalizão I e II \\
\hline Amir Lando & $\mathrm{NO}$ & RO & PMDB & Coalizão I e II \\
\hline Ernandes Amorim & NO & RO & PPB & Coalizão II \\
\hline Romero Jucá & NO & RR & PSDB & Coalizão I e II \\
\hline Marluce Pinto & $\mathrm{NO}$ & $\mathrm{RR}$ & PMDB & Coalizão I e II \\
\hline Mozarildo Cavancanti & NO & $\mathrm{RR}$ & PTB & Coalizão I e II \\
\hline Eduardo Siqueira Campos & $\mathrm{NO}$ & TO & PSDB & Coalizão I e II \\
\hline Leomar Quintanilha & NO & TO & PFL & Coalizão I e II \\
\hline Carlos Patrocínio & $\mathrm{NO}$ & TO & PTB & Coalizão I e II \\
\hline Teotônio Vilela Filho & NE & $\mathrm{AL}$ & PSDB & Coalizão I e II \\
\hline Renan Calheiros & $\mathrm{NE}$ & $\mathrm{AL}$ & PMDB & Coalizão I e II \\
\hline Heloísa Helena & NE & $\mathrm{AL}$ & PT & Oposição \\
\hline Antônio Carlos Magalhães & NE & BA & PFL & Coalizão I e II \\
\hline Paulo Souto & NE & BA & PFL & Coalizão I e II \\
\hline Waldeck Ornellas & $\mathrm{NE}$ & BA & PFL & Coalizão I e II \\
\hline Lúcio Alcântara & NE & $\mathrm{CE}$ & PSDB & Coalizão I e II \\
\hline Luiz Pontes & $\mathrm{NE}$ & $\mathrm{CE}$ & PSDB & Coalizão I e II \\
\hline Sérgio Machado & $\mathrm{NE}$ & $\mathrm{CE}$ & PMDB & Coalizão I e II \\
\hline Alexandre Costa & $\mathrm{NE}$ & MA & PFL & Coalizão I e II \\
\hline Edison Lobão & $\mathrm{NE}$ & MA & PFL & Coalizão I e II \\
\hline João Alberto Souza & $\mathrm{NE}$ & MA & PMDB & Coalizão I e II \\
\hline Ronaldo Cunha Lima & NE & $\mathrm{PB}$ & PSDB & Coalizão I e II \\
\hline Humberto Lucena & $\mathrm{NE}$ & PB & PMDB & Coalizão I e II \\
\hline Ney Suassuna & $\mathrm{NE}$ & PB & PMDB & Coalizão I e II \\
\hline José Jorge & NE & PE & PFL & Coalizão I e II \\
\hline
\end{tabular}




\begin{tabular}{|c|c|c|c|c|}
\hline Carlos Wilson & NE & PE & PTB & Coalizão I e II \\
\hline Roberto Freire & NE & PE & PPS & Oposição \\
\hline Freitas Neto & NE & PI & PSDB & Coalizão I e II \\
\hline Hugo Napoleão & NE & PI & PFL & Coalizão I e II \\
\hline Alberto Dias & $\mathrm{NE}$ & PI & PMDB & Coalizão I e II \\
\hline Geraldo Melo & NE & $\mathrm{RN}$ & PSDB & Coalizão I e II \\
\hline José Agripino Maia & NE & $\mathrm{RN}$ & PFL & Coalizão I e II \\
\hline Fernando Bezerra & $\mathrm{NE}$ & $\mathrm{RN}$ & PTB & Coalizão I e II \\
\hline Maria do Carmo Alves & NE & SE & PFL & Coalizão I e II \\
\hline Antonio Carlos Valadares & NE & SE & PSB & Oposição \\
\hline José Eduardo Dutra & NE & SE & PT & Oposição \\
\hline José Roberto Arruda & $\mathrm{CO}$ & DF & PSDB & Coalizão I e II \\
\hline Luiz Estevão & $\mathrm{CO}$ & DF & PMDB & Coalizão I e II \\
\hline Lauro Campos & $\mathrm{CO}$ & DF & PDT & Oposição \\
\hline Iris Resende & $\mathrm{CO}$ & GO & PMDB & Coalizão I e II \\
\hline Maguito Vilela & $\mathrm{CO}$ & GO & PMDB & Coalizão I e II \\
\hline Mauro Miranda & $\mathrm{CO}$ & GO & PMDB & Coalizão I e II \\
\hline Juvêncio da Fonseca & $\mathrm{CO}$ & MS & PSDB & Coalizão I e II \\
\hline Lúdio Coelho & $\mathrm{CO}$ & MS & PSDB & Coalizão I e II \\
\hline Ramez Tebet & $\mathrm{CO}$ & MS & PMDB & Coalizão I e II \\
\hline Antero Paes de Barros & $\mathrm{CO}$ & MT & PSDB & Coalizão I e II \\
\hline Jonas Pinheiro & $\mathrm{CO}$ & MT & PFL & Coalizão I e II \\
\hline Carlos Bezerra & $\mathrm{CO}$ & MT & PMDB & Coalizão I e II \\
\hline José Ignácio Ferreira & SE & ES & PSDB & Coalizão I e II \\
\hline Gerson Camata & $\mathrm{SE}$ & ES & PMDB & Coalizão I e II \\
\hline Paulo Hartung & SE & $\mathrm{ES}$ & PSB & Oposição \\
\hline Francelino Pereira & $\mathrm{SE}$ & MG & PFL & Coalizão I e II \\
\hline Arlindo Porto & $\mathrm{SE}$ & MG & PTB & Coalizão I e II \\
\hline José Alencar & $\mathrm{SE}$ & MG & PL & Coalizão II \\
\hline Artur da Távola & $\mathrm{SE}$ & RJ & PSDB & Coalizão I e II \\
\hline Benedita da Silva & SE & RJ & PT & Oposição \\
\hline Roberto Saturnino & SE & RJ & PT & Oposição \\
\hline José Serra & SE & SP & PSDB & Coalizão I e II \\
\hline
\end{tabular}




\begin{tabular}{|l|c|c|c|c|}
\hline Romeu Tuma & SE & SP & PFL & Coalizão I e II \\
\hline Eduardo Suplicy & SE & SP & PT & Oposição \\
\hline Álvaro Dias & SU & PR & PSDB & Coalizão I e II \\
\hline Roberto Requião & SU & PR & PMDB & Coalizão I e II \\
\hline Osmar Dias & SU & PR & PDT & Oposição \\
\hline Pedro Simon & SU & RS & PMDB & Coalizão I e II \\
\hline Emília Fernandes & SU & RS & PT & Oposição \\
\hline José Fogaça & SU & RS & PPS & Oposição \\
\hline Jorge Bornhausen & SU & SC & PFL & Coalizão I e II \\
\hline Vilson Kleinübing & SU & SC & PFL & Coalizão I e II \\
\hline Casildo Maldaner & SU & SC & PMDB & Coalizão I e II \\
\hline
\end{tabular}

SENADORES EX-SUPLENTES na 51 ${ }^{\text {a }}$ LEGISLATURA (1999-2003) - por região.

\begin{tabular}{|l|c|c|c|c|}
\hline NOME & REGIÃO & ESTADO & PARTIDO & POSIÇÃO \\
\hline Júlio Eduardo & NO & AC & PV & Oposição \\
\hline Gilberto Miranda & NO & AM & PFL & Coalizão I e II \\
\hline João Thomé Mestrinho & NO & AM & PMDB & Coalizão I e II \\
\hline Nova da Costa & NO & AP & PMDB & Coalizão I e II \\
\hline Maria Benigna Jucá & NO & AP & PSB & Oposição \\
\hline Fernando Ribeiro & NO & PA & PMDB & Coalizão I e II \\
\hline Chico Sartori & NO & RO & PSDB & Coalizão I e II \\
\hline Moreira Mendes & NO & RO & PFL & Coalizão I e II \\
\hline Mário Calixto & NO & RO & PMDB & Coalizão I e II \\
\hline Paulo Elifas & NO & RO & PMDB & Coalizão I e II \\
\hline Fernando Matusalém & NO & RO & PTB & Coalizão I e II \\
\hline José Bonifácio & NO & TO & PPB & Coalizão II \\
\hline Thelma Siqueira Campos & NO & TO & PPB & Coalizão II \\
\hline Totó Cavalcante & NO & TO & PPB & Coalizão II \\
\hline Geraldo Lessa & NE & AL & PSDB & Coalizão I e II \\
\hline Djalma Falcão & NE & AL & PMDB & Coalizão I e II \\
\hline Antonio Carlos Júnior & NE & BA & PFL & Coalizão I e II \\
\hline Djalma Bessa & NE & BA & PFL & Coalizão I e II \\
\hline
\end{tabular}




\begin{tabular}{|c|c|c|c|c|}
\hline Rodolpho Tourinho & $\mathrm{NE}$ & BA & PFL & Coalizão I e II \\
\hline Luiz Girão & NE & $\mathrm{CE}$ & PSDB & Coalizão I e II \\
\hline Reginaldo Duarte & $\mathrm{NE}$ & $\mathrm{CE}$ & PSDB & Coalizão I e II \\
\hline Bello Parga & NE & MA & PFL & Coalizão I e II \\
\hline Antônio Leite & $\mathrm{NE}$ & MA & PMDB & Coalizão I e II \\
\hline Francisco Escórcio & $\mathrm{NE}$ & MA & PMDB & Coalizão I e II \\
\hline Ribamar Fiquene & $\mathrm{NE}$ & MA & PMDB & Coalizão I e II \\
\hline Robinson Viana & NE & PB & PMDB & Coalizão I e II \\
\hline Silva Júnior & NE & PB & PMDB & Coalizão I e II \\
\hline José Coelho & $\mathrm{NE}$ & PE & PFL & Coalizão I e II \\
\hline Wellington Roberto & $\mathrm{NE}$ & PE & PTB & Coalizão I e II \\
\hline Clodoaldo Torres & NE & PE & PTB & Coalizão I e II \\
\hline Meira Lins & NE & PE & Sem registro & Indefinido \\
\hline Benício Sampaio & $\mathrm{NE}$ & PI & PPB & Coalizão II \\
\hline Elói Portela & $\mathrm{NE}$ & PI & PPB & Coalizão II \\
\hline Agnelo Alves & $\mathrm{NE}$ & $\mathrm{RN}$ & PMDB & Coalizão I e II \\
\hline Tasso Rosado & $\mathrm{NE}$ & $\mathrm{RN}$ & PTB & Coalizão I e II \\
\hline Renildo Santana & $\mathrm{NE}$ & $\mathrm{SE}$ & PFL & Coalizão I e II \\
\hline Valdiolanda Teófilo & $\mathrm{NE}$ & $\mathrm{SE}$ & PT & Oposição \\
\hline Lindberg Cury & $\mathrm{CO}$ & DF & PFL & Coalizão I e II \\
\hline Valmir Amaral & $\mathrm{CO}$ & DF & PTB & Coalizão I e II \\
\hline Ulisses Riedel & $\mathrm{CO}$ & DF & PSB & Oposição \\
\hline Albino Boaventura & $\mathrm{CO}$ & GO & PMDB & Coalizão I e II \\
\hline Iris de Araújo & $\mathrm{CO}$ & GO & PMDB & Coalizão I e II \\
\hline Otoniel Machado & $\mathrm{CO}$ & GO & PMDB & Coalizão I e II \\
\hline Pedro Ubirajara & $\mathrm{CO}$ & MS & PMDB & Coalizão I e II \\
\hline Blairo Maggi & $\mathrm{CO}$ & MT & Sem partido & Indefinido \\
\hline Luiz Soares & $\mathrm{CO}$ & MT & Sem partido & Indefinido \\
\hline João Batista Motta & $\mathrm{SE}$ & $\mathrm{ES}$ & PSDB & Coalizão I e II \\
\hline Luzia Toledo & SE & ES & PSDB & Coalizão I e II \\
\hline Ricardo Santos & SE & $\mathrm{ES}$ & PSDB & Coalizão I e II \\
\hline Luiz Pastore & SE & ES & PMDB & Coalizão I e II \\
\hline Regina Assumpção & $\mathrm{SE}$ & MG & РTB & Coalizão I e II \\
\hline
\end{tabular}




\begin{tabular}{|l|c|c|c|c|}
\hline Aelton Freitas & SE & MG & PL & Coalizão II \\
\hline Nilo Teixeira Campos & SE & RJ & PSDB & Coalizão I e II \\
\hline Geraldo Cândido & SE & RJ & PT & Oposição \\
\hline Pedro Piva & SE & SP & PSDB & Coalizão I e II \\
\hline Olivir Gabardo & SU & PR & PSDB & Coalizão I e II \\
\hline Nivaldo Krüguer & SU & PR & PMDB & Coalizão I e II \\
\hline Edir Domeneguini & SU & RS & PTB & Coalizão I e II \\
\hline Geraldo Althoff & SU & SC & PFL & Coalizão I e II \\
\hline Henrique Loyola & SU & SC & PMDB & Coalizão I e II \\
\hline Ari Stadler & SU & SC & PPB & Coalizão I e II \\
\hline Vasco Furlan & SU & SC & PPB & Coalizão II \\
\hline
\end{tabular}

\section{4 - Votação dos senadores nas emendas constitucionais de tema fiscal por} ordem alfabética.

Emenda Constitucional de Revisão n.1 (Fundo Social de Emergência).

\begin{tabular}{|l|c|c|c|c|}
\hline NOME & ESTADO & PARTIDO & $\mathbf{1}^{\mathbf{0}}$ TURNO - 9/2/94 & $\mathbf{2}^{\mathbf{0}}$ TURNO - 24/2/94 \\
\hline Abdias Nascimento & RJ & PDT & Ausente & Ausente \\
\hline Albano Franco & SE & PRN & Sim & Sim \\
\hline Alfredo Campos & MG & PMDB & Sim & Sim \\
\hline Almir Gabriel & PA & PSDB & Sim & Ausente \\
\hline Aluízio Bezerra & AC & PMDB & Sim & Ausente \\
\hline Amazonino Mendes & AM & PFL & Ausente & Sim \\
\hline Amir Lando & RO & PMDB & Não & Ausente \\
\hline Antonio Alves & GO & ---- & Ausente & Sim \\
\hline Antonio Mariz & PB & PMDB & Sim & Ausente \\
\hline Áureo Mello & AM & PRN & Sim & Sim \\
\hline Bello Parga & MA & PFL & Ausente & Sim \\
\hline Beni Veras & CE & PSDB & Sim & Sim \\
\hline Carlos Patrocínio & TO & PFL & & \\
\hline
\end{tabular}




\begin{tabular}{|c|c|c|c|c|}
\hline Cesar Dias & RR & PMDB & Sim & Não \\
\hline Chagas Rodrigues & PI & PSDB & Sim & Sim \\
\hline Cid Sabóia de Carvalho & $\mathrm{CE}$ & PMDB & Não & Não \\
\hline Coutinho Jorge & PA & PMDB & Sim & Sim \\
\hline Darcy Ribeiro & RJ & PDT & Ausente & Ausente \\
\hline Dario Pereira & $\mathrm{RN}$ & PFL & Sim & Sim \\
\hline Dirceu Carneiro & $\mathrm{SC}$ & PSDB & Sim & Ausente \\
\hline Divaldo Suruagy & $\mathrm{AL}$ & PMDB & Sim & Sim \\
\hline Edison Lobão & MA & PFL & Ausente & Ausente \\
\hline Eduardo Suplicy & SP & PT & Ausente & Não \\
\hline Elcio Álvares & $\mathrm{ES}$ & PFL & Ausente & Ausente \\
\hline Epitácio Cafeteira & MA & PPR & Ausente & Ausente \\
\hline Espiridião Amin & $\mathrm{SC}$ & PDS & Sim & Sim \\
\hline Eva Blay & SP & PSDB & Sim & Sim \\
\hline Flaviano Melo & $\mathrm{AC}$ & PMDB & Sim & Sim \\
\hline Francisco Rollemberg & $\mathrm{SE}$ & PFL & Ausente & Não \\
\hline Garibaldi Alves & RN & PMDB & Sim & Sim \\
\hline Gerson Camata & $\mathrm{ES}$ & PDC & Sim & Sim \\
\hline Gilberto Miranda & $\mathrm{AM}$ & PMDB & Sim & Sim \\
\hline Guilherme Palmeira & $\mathrm{AL}$ & PFL & Sim & Sim \\
\hline Henrique Almeida & $\mathrm{AP}$ & PFL & Sim & Sim \\
\hline Hugo Napoleão & PI & PFL & Sim & Sim \\
\hline Humberto Lucena & PB & PMDB & Abstenção & Abstenção \\
\hline Jacques Silva & GO & PMDB & Ausente & Ausente \\
\hline João França & RR & $\mathrm{PP}$ & Sim & Sim \\
\hline João Rocha & TO & PFL & Sim & Sim \\
\hline Jonas Pinheiro & AP & PTB & Sim & Sim \\
\hline Jonice Tristão & $\mathrm{ES}$ & PFL & Sim & Sim \\
\hline Jorge Bornhausen & $\mathrm{SC}$ & PFL & Ausente & Ausente \\
\hline Josaphat Marinho & BA & PFL & Não & Não \\
\hline José Eduardo & PR & PTB & Sim & Ausente \\
\hline José Fogaça & $\mathrm{RS}$ & PMDB & Sim & Ausente \\
\hline José Paulo Bisol & $\mathrm{RS}$ & PSB & Ausente & Ausente \\
\hline
\end{tabular}




\begin{tabular}{|c|c|c|c|c|}
\hline José Richa & PR & PSDB & Sim & Sim \\
\hline José Sarney & AP & PMDB & Ausente & Ausente \\
\hline Júlio Campos & MT & PFL & Sim & Sim \\
\hline Junia Marise & MG & PRN & Ausente & Não \\
\hline Jutahy Magalhães & BA & PSDB & Sim & Sim \\
\hline Lavoisier Maia & RN & PDT & Ausente & Não \\
\hline Leite Chaves & PR & РTB & Ausente & Ausente \\
\hline Levy Dias & MS & PTB & Sim & Sim \\
\hline Lourival Baptista & SE & PFL & Sim & Ausente \\
\hline Lucídio Portella & PI & PDS & Não & Não \\
\hline Mansueto de Lavor & $\mathrm{PE}$ & PMDB & Sim & Sim \\
\hline Márcio Lacerda & MT & PMDB & Sim & Sim \\
\hline Marco Maciel & $\mathrm{PE}$ & PFL & Sim & Sim \\
\hline Mário Covas & SP & PSDB & Sim & Sim \\
\hline Marluce Pinto & $\mathrm{RR}$ & PTB & Sim & Sim \\
\hline Mauro Benevides & CE & PMDB & Sim & Sim \\
\hline Meira Filho & DF & PP & Sim & Sim \\
\hline Moisés Abrão & TO & PDC & Sim & Sim \\
\hline Nabor Júnior & $\mathrm{AC}$ & PMDB & Sim & Sim \\
\hline Nelson Carneiro & RJ & PMDB & Sim & Sim \\
\hline Ney Maranhão & $\mathrm{PE}$ & PRN & Ausente & Sim \\
\hline Odacir Soares & RO & PFL & Sim & Ausente \\
\hline Onofre Quinan & GO & PMDB & Ausente & Sim \\
\hline Oziel Carneiro & PA & PDS & Ausente & Ausente \\
\hline Pedro Simon & $\mathrm{RS}$ & PMDB & Sim & Sim \\
\hline Pedro Teixeira & $\mathrm{DF}$ & PP & Sim & Ausente \\
\hline Rachid Saldanha Derzi & MS & PRN & Sim & Sim \\
\hline Raimundo Lira & $\mathrm{PB}$ & PFL & Sim & Sim \\
\hline Ronaldo Aragão & RO & PMDB & Ausente & Ausente \\
\hline Ronan Tito & MG & PMDB & Sim & Sim \\
\hline Ruy Bacelar & BA & PMDB & Ausente & Sim \\
\hline Teotônio Vilela Filho & $\mathrm{AL}$ & PSDB & Sim & Ausente \\
\hline Valmir Campelo & DF & PTB & Sim & Sim \\
\hline
\end{tabular}




\begin{tabular}{|l|c|c|c|c|}
\hline Wilson Martins & MS & PMDB & Sim & Sim \\
\hline Zanete Cardinal & MT & PFL & Ausente & Ausente \\
\hline
\end{tabular}

Emenda Constitucional n.10 (Fundo de Estabilização Fiscal).

\begin{tabular}{|c|c|c|c|c|}
\hline NOME & ESTADO & PARTIDO & $1^{\circ}$ TURNO - 13/2/96 & $2^{\circ}$ TURNO - 29/2/96 \\
\hline Ademir Andrade & PA & PSB & Não & Não \\
\hline $\begin{array}{l}\text { Antonio Carlos Maga- } \\
\text { lhães }\end{array}$ & BA & PFL & Sim & Sim \\
\hline $\begin{array}{l}\text { Antonio Carlos Valada- } \\
\text { res }\end{array}$ & $\mathrm{SE}$ & PSB & Não & Ausente \\
\hline Arlindo Porto & $\mathrm{SE}$ & PTB & Ausente & Ausente \\
\hline Artur da Távola & RJ & PSDB & Sim & Sim \\
\hline Bello Parga & MA & PFL & Sim & Sim \\
\hline Benedita da Silva & RJ & PT & Não & Ausente \\
\hline Beni Veras & $\mathrm{CE}$ & PSDB & Sim & Sim \\
\hline Bernardo Cabral & PFL & $\mathrm{AM}$ & Sim & Sim \\
\hline Carlos Bezerra & MT & PMDB & Sim & Sim \\
\hline Carlos Patrocínio & TO & PFL & Sim & Sim \\
\hline Carlos Wilson & $\mathrm{PE}$ & PTB & Sim & Ausente \\
\hline Casildo Maldaner & $\mathrm{SC}$ & PMDB & Sim & Sim \\
\hline Coutinho Jorge & PA & PSDB & Ausente & Sim \\
\hline Darcy Ribeiro & RJ & PDT & Sim & Ausente \\
\hline Edison Lobão & MA & PFL & Sim & Sim \\
\hline Eduardo Suplicy & SP & PT & Não & Não \\
\hline Elcio Álvares & $\mathrm{ES}$ & PFL & Sim & Sim \\
\hline Emília Fernandes & $\mathrm{RS}$ & $\mathrm{PT}$ & Sim & Sim \\
\hline Epitácio Cafeteira & MA & PPB & Sim & Sim \\
\hline Ernandes Amorim & $\mathrm{RO}$ & PPB & Ausente & Ausente \\
\hline Espiridião Amin & $\mathrm{SC}$ & PPB & Sim & Sim \\
\hline Fernando Bezerra & RN & PMDB & Sim & Sim \\
\hline Flaviano Melo & $\mathrm{AC}$ & PMDB & Sim & Sim \\
\hline Francelino Pereira & $\mathrm{MG}$ & PFL & Ausente & Ausente \\
\hline
\end{tabular}




\begin{tabular}{|c|c|c|c|c|}
\hline Freitas Neto & PI & PSDB & Sim & Sim \\
\hline Geraldo Melo & RN & PSDB & Sim & Sim \\
\hline Gerson Camata & $\mathrm{ES}$ & PMDB & Sim & Sim \\
\hline Gilberto Miranda & $\mathrm{AM}$ & PMDB & Sim & Sim \\
\hline Gilvam Borges & AP & PMDB & Ausente & Ausente \\
\hline Guilherme Palmeira & $\mathrm{AL}$ & PFL & Sim & Sim \\
\hline Hugo Napoleão & PI & PFL & Sim & Ausente \\
\hline Humberto Lucena & $\mathrm{PB}$ & PMDB & Sim & Sim \\
\hline Iris Rezende & GO & PMDB & Sim & Sim \\
\hline Jader Barbalho & PA & PMDB & Sim & Sim \\
\hline Jefferson Peres & $\mathrm{AM}$ & PDT & Sim & Ausente \\
\hline João França & RR & PPB & Sim & Sim \\
\hline João Rocha & TO & PFL & Sim & Sim \\
\hline Joel de Hollanda & $\mathrm{PE}$ & PFL & Sim & Sim \\
\hline Jonas Pinheiro & MT & PFL & Sim & Sim \\
\hline Josaphat Marinho & BA & PFL & Não & Sim \\
\hline José Agripino Maia & $\mathrm{SC}$ & PFL & Sim & Sim \\
\hline José Alves & $\mathrm{SE}$ & PFL & Sim & Sim \\
\hline José Bianco & RO & PFL & Sim & Sim \\
\hline José Eduardo Dutra & $\mathrm{SE}$ & PT & Não & Não \\
\hline José Fogaça & $\mathrm{RS}$ & PPS & Sim & Sim \\
\hline José Ignácio Ferreira & $\mathrm{ES}$ & PSDB & Sim & Sim \\
\hline José Roberto Arruda & $\mathrm{DF}$ & PSDB & Sim & Sim \\
\hline José Sarney & AP & PMDB & Abstenção & Ausente \\
\hline Júlio Campos & MT & PFL & Sim & Ausente \\
\hline Junia Marise & MG & PDT & Não & Ausente \\
\hline Lauro Campos & DF & PDT & Não & Não \\
\hline Leomar Quintanilha & TO & PFL & Sim & Sim \\
\hline Levy Dias & MS & PPB & Ausente & Ausente \\
\hline Lucídio Portella & PI & PPB & Sim & Ausente \\
\hline Lúcio Alcântara & $\mathrm{CE}$ & PSDB & Sim & Sim \\
\hline Lúdio Coelho & MS & PSDB & Sim & Sim \\
\hline Luís Alberto de Olivei- & PR & PTB & Sim & Sim \\
\hline
\end{tabular}




\begin{tabular}{|c|c|c|c|c|}
\hline \multicolumn{5}{|l|}{ ra } \\
\hline Marina Silva & $\mathrm{AC}$ & PT & Não & Não \\
\hline Marluce Pinto & RR & PMDB & Sim & Sim \\
\hline Mauro Miranda & GO & PMDB & Sim & Sim \\
\hline Nabor Júnior & $\mathrm{AC}$ & PMDB & Sim & Sim \\
\hline Ney Suassuna & PB & PMDB & Ausente & Sim \\
\hline Odacir Soares & $\mathrm{RO}$ & PTB & Ausente & Ausente \\
\hline Onofre Quinan & GO & PMDB & Ausente & Ausente \\
\hline Osmar Dias & PR & PDT & Sim & Sim \\
\hline Pedro Piva & SP & PSDB & Sim & Sim \\
\hline Pedro Simon & $\mathrm{RS}$ & PMDB & Sim & Sim \\
\hline Ramez Tebet & MS & PMDB & Sim & Sim \\
\hline Renan Calheiros & $\mathrm{AL}$ & PMDB & Sim & Ausente \\
\hline Roberto Freire & PE & PPS & Sim & Sim \\
\hline Roberto Requião & PR & PMDB & Sim & Ausente \\
\hline Romero Jucá & RR & PSDB & Sim & Sim \\
\hline Romeu Tuma & SP & PFL & Sim & Sim \\
\hline Ronaldo Cunha Lima & PB & PSDB & Abstenção & Sim \\
\hline Sebastião Rocha & AP & PDT & Não & Ausente \\
\hline Sérgio Machado & $\mathrm{CE}$ & PMDB & Sim & Sim \\
\hline Teotônio Vilela Filho & $\mathrm{AL}$ & PSDB & Sim & Abstenção \\
\hline Valmir Campelo & $\mathrm{DF}$ & PTB & Sim & Sim \\
\hline Vilson Kleinübing & $\mathrm{SC}$ & PFL & Sim & Sim \\
\hline Waldeck Ornellas & BA & PFL & Sim & Sim \\
\hline
\end{tabular}

Emenda Constitucional n.17 (Fundo de Estabilização Fiscal 2).

\begin{tabular}{|l|c|c|c|c|c|}
\hline NOME & ESTADO & PARTIDO & $\begin{array}{c}\mathbf{1}^{\mathbf{0}} \text { TURNO - } \\
\mathbf{5 / 1 1 / 9 7}\end{array}$ & $\begin{array}{c}\text { Emenda 1 - } \\
\mathbf{5 / 1 1 / 9 7}\end{array}$ & $\begin{array}{c}\mathbf{2}^{\mathbf{0}} \text { TURNO - } \\
\mathbf{1 9 / 1 1 / 9 7}\end{array}$ \\
\hline $\begin{array}{l}\text { Abdias Nasci- } \\
\text { mento }\end{array}$ & RJ & PDT & Ausente & Ausente & Não \\
\hline Ademir Andrade & PA & PSB & Não & Abstenção & Não \\
\hline Albino Boaven- & GO & PMDB & Sim & Sim & Sim \\
\hline
\end{tabular}




\begin{tabular}{|c|c|c|c|c|c|}
\hline tura & & & & & \\
\hline $\begin{array}{l}\text { Antonio Carlos } \\
\text { Magalhães }\end{array}$ & BA & PFL & Abstenção & Abstenção & Abstenção \\
\hline $\begin{array}{l}\text { Antonio Carlos } \\
\text { Valadares }\end{array}$ & SE & PSB & Não & Abstenção & Não \\
\hline Artur da Távola & RJ & PSDB & Ausente & Ausente & Ausente \\
\hline Bello Parga & MA & PFL & Sim & Sim & Sim \\
\hline Benedita da Silva & $\mathrm{RJ}$ & PT & Ausente & Ausente & Não \\
\hline Beni Veras & $\mathrm{CE}$ & PSDB & Sim & Sim & Sim \\
\hline Bernardo Cabral & PFL & $\mathrm{AM}$ & Sim & Sim & Sim \\
\hline Carlos Bezerra & MT & PMDB & Sim & Sim & Sim \\
\hline Carlos Patrocínio & TO & PFL & Sim & Sim & Sim \\
\hline Carlos Wilson & $\mathrm{PE}$ & PTB & Sim & Sim & Sim \\
\hline $\begin{array}{l}\text { Casildo Malda- } \\
\text { ner }\end{array}$ & $\mathrm{SC}$ & PMDB & Sim & Sim & Sim \\
\hline Coutinho Jorge & PA & PSDB & Sim & Sim & Sim \\
\hline Edison Lobão & MA & PFL & Sim & Sim & Sim \\
\hline Eduardo Suplicy & SP & $\mathrm{PT}$ & Não & Abstenção & Não \\
\hline Elcio Álvares & ES & PFL & Sim & Sim & Sim \\
\hline Emília Fernandes & $\mathrm{RS}$ & $\mathrm{PT}$ & Não & Não & Não \\
\hline $\begin{array}{l}\text { Epitácio Cafetei- } \\
\text { ra }\end{array}$ & MA & PPB & Não & Ausente & Não \\
\hline $\begin{array}{l}\text { Ernandes Amo- } \\
\text { rim }\end{array}$ & RO & PPB & Ausente & Ausente & Sim \\
\hline Espiridião Amin & $\mathrm{SC}$ & PPB & Sim & Sim & Sim \\
\hline $\begin{array}{l}\text { Fernando Bezer- } \\
\text { ra }\end{array}$ & $\mathrm{RN}$ & PMDB & Sim & Sim & Sim \\
\hline Flaviano Melo & $\mathrm{AC}$ & PMDB & Sim & Sim & Ausente \\
\hline $\begin{array}{l}\text { Francelino Perei- } \\
\text { ra }\end{array}$ & MG & PFL & Sim & Sim & Sim \\
\hline Freitas Neto & PI & PSDB & Sim & Sim & Sim \\
\hline Geraldo Melo & $\mathrm{RN}$ & PSDB & Sim & Sim & Sim \\
\hline Gerson Camata & ES & PMDB & Sim & Sim & Sim \\
\hline
\end{tabular}




\begin{tabular}{|c|c|c|c|c|c|}
\hline Gilberto Miranda & $\mathrm{AM}$ & PMDB & Sim & Sim & Sim \\
\hline Gilvam Borges & AP & PMDB & Ausente & Ausente & Não \\
\hline $\begin{array}{l}\text { Guilherme Pal- } \\
\text { meira }\end{array}$ & $\mathrm{AL}$ & PFL & Sim & Sim & Sim \\
\hline Hugo Napoleão & PI & PFL & Sim & Sim & Sim \\
\hline $\begin{array}{l}\text { Humberto Luce- } \\
\text { na }\end{array}$ & PB & PMDB & Sim & Sim & Sim \\
\hline Jader Barbalho & PA & PMDB & Sim & Sim & Sim \\
\hline Jefferson Peres & AM & PDT & Sim & Ausente & Sim \\
\hline João França & RR & PPB & Sim & Sim & Sim \\
\hline João Rocha & TO & PFL & Sim & Sim & Sim \\
\hline Joel de Hollanda & $\mathrm{PE}$ & PFL & Sim & Sim & Ausente \\
\hline Jonas Pinheiro & MT & PFL & Sim & Sim & Sim \\
\hline $\begin{array}{l}\text { Josaphat Mari- } \\
\text { nho }\end{array}$ & BA & PFL & Não & Abstenção & Não \\
\hline $\begin{array}{l}\text { José Agripino } \\
\text { Maia }\end{array}$ & RN & PFL & Sim & Sim & Sim \\
\hline José Alves & SE & PFL & Sim & Sim & Sim \\
\hline José Bianco & RO & PFL & Sim & Sim & Sim \\
\hline José Eduardo & PR & PTB & Sim & Sim & Sim \\
\hline $\begin{array}{l}\text { José Eduardo } \\
\text { Dutra }\end{array}$ & SE & PT & Não & Abstenção & Não \\
\hline José Fogaça & $\mathrm{RS}$ & PPS & Sim & Sim & Sim \\
\hline $\begin{array}{l}\text { José Ignácio Fer- } \\
\text { reira }\end{array}$ & ES & PSDB & Sim & Sim & Sim \\
\hline $\begin{array}{l}\text { José Roberto Ar- } \\
\text { ruda }\end{array}$ & DF & PSDB & Sim & Sim & Sim \\
\hline José Sarney & AP & PMDB & Ausente & Ausente & Ausente \\
\hline José Serra & SP & PSDB & Sim & Sim & Sim \\
\hline Júlio Campos & MT & PFL & Sim & Sim & Sim \\
\hline Junia Marise & MG & PDT & Não & Abstenção & Não \\
\hline Lauro Campos & DF & PDT & Não & Abstenção & Não \\
\hline Leomar Quinta- & TO & PFL & Sim & Sim & Ausente \\
\hline
\end{tabular}




\begin{tabular}{|c|c|c|c|c|c|}
\hline nilha & & & & & \\
\hline Levy Dias & MS & PPB & Sim & Sim & Não \\
\hline Lucídio Portella & PI & PPB & Sim & Sim & Ausente \\
\hline Lúcio Alcântara & $\mathrm{CE}$ & PSDB & Sim & Sim & Sim \\
\hline Lúdio Coelho & MS & PSDB & Sim & Sim & Ausente \\
\hline Marina Silva & $\mathrm{AC}$ & PT & Não & Ausente & Ausente \\
\hline Marluce Pinto & $\mathrm{RR}$ & PMDB & Sim & Sim & Sim \\
\hline Nabor Júnior & $\mathrm{AC}$ & PMDB & Sim & Sim & Sim \\
\hline Ney Suassuna & PB & PMDB & Sim & Sim & Sim \\
\hline Odacir Soares & RO & PTB & Sim & Sim & Sim \\
\hline Onofre Quinan & GO & PMDB & Sim & Sim & Sim \\
\hline Osmar Dias & PR & PDT & Sim & Sim & Sim \\
\hline Otoniel Machado & GO & PMDB & Sim & Sim & Sim \\
\hline Pedro Simon & $\mathrm{RS}$ & PMDB & Sim & Sim & Sim \\
\hline Ramez Tebet & MS & PMDB & Sim & Sim & Ausente \\
\hline $\begin{array}{l}\text { Regina Assump- } \\
\text { ção }\end{array}$ & MG & PTB & Ausente & Ausente & Sim \\
\hline Renan Calheiros & $\mathrm{AL}$ & PMDB & Sim & Ausente & Sim \\
\hline Roberto Freire & $\mathrm{PE}$ & PPS & Sim & Ausente & Sim \\
\hline Roberto Requião & PR & PMDB & Não & Sim & Não \\
\hline Romero Jucá & RR & PSDB & Sim & Sim & Ausente \\
\hline Romeu Tuma & SP & PFL & Sim & Sim & Sim \\
\hline $\begin{array}{l}\text { Ronaldo Cunha } \\
\text { Lima }\end{array}$ & PB & PSDB & Sim & Sim & Sim \\
\hline Sebastião Rocha & AP & PDT & Não & Não & Não \\
\hline Sérgio Machado & $\mathrm{CE}$ & PMDB & Sim & Sim & Sim \\
\hline $\begin{array}{l}\text { Teotônio Vilela } \\
\text { Filho }\end{array}$ & $\mathrm{AL}$ & PSDB & Sim & Sim & Sim \\
\hline Valmir Campelo & DF & PTB & Sim & Sim & Ausente \\
\hline $\begin{array}{l}\text { Vilson Kleinü- } \\
\text { bing }\end{array}$ & $\mathrm{SC}$ & PFL & Sim & Sim & Sim \\
\hline $\begin{array}{l}\text { Waldeck Ornel- } \\
\text { las }\end{array}$ & BA & PFL & Sim & Sim & Ausente \\
\hline
\end{tabular}


Emenda Constitucional n.27 (Desvinculação das Receitas da União).

\begin{tabular}{|c|c|c|c|c|}
\hline NOME & ESTADO & PARTIDO & $1^{\circ}$ TURNO - 23/2/00 & $2^{\circ}$ TURNO - 15/03/00 \\
\hline Ademir Andrade & PA & PSB & Não & Não \\
\hline Agnelo Alves & RN & PMDB & Sim & Sim \\
\hline Alberto Dias & PI & PMDB & Sim & Ausente \\
\hline Amir Lando & RO & PMDB & Sim & Sim \\
\hline $\begin{array}{l}\text { Antero Paes de } \\
\text { Barros }\end{array}$ & MT & PSDB & Sim & Sim \\
\hline $\begin{array}{l}\text { Antonio Carlos } \\
\text { Magalhães }\end{array}$ & BA & PFL & Abstenção & Abstenção \\
\hline $\begin{array}{l}\text { Antonio Carlos Va- } \\
\text { ladares }\end{array}$ & SE & PSB & Não & Não \\
\hline Arlindo Porto & MG & PTB & Sim & Sim \\
\hline Artur da Távola & RJ & PSDB & Sim & Ausente \\
\hline Bello Parga & MA & PFL & Sim & Sim \\
\hline Bernardo Cabral & PFL & $\mathrm{AM}$ & Sim & Sim \\
\hline Carlos Bezerra & MT & PMDB & Sim & Sim \\
\hline Carlos Patrocínio & TO & PFL & Sim & Sim \\
\hline Carlos Wilson & $\mathrm{PE}$ & PTB & Não & Não \\
\hline Casildo Maldaner & $\mathrm{SC}$ & PMDB & Sim & Sim \\
\hline Djalma Bessa & BA & PFL & Sim & Sim \\
\hline Edison Lobão & MA & PFL & Sim & Sim \\
\hline $\begin{array}{l}\text { Eduardo Siqueira } \\
\text { Campos }\end{array}$ & TO & PSDB & Ausente & Sim \\
\hline Eduardo Suplicy & SP & $\mathrm{PT}$ & Não & Ausente \\
\hline Emília Fernandes & $\mathrm{RS}$ & PT & Não & Não \\
\hline Ernandes Amorim & RO & PPB & Sim & Sim \\
\hline Francelino Pereira & MG & PFL & Sim & Sim \\
\hline Freitas Neto & PI & PSDB & Sim & Sim \\
\hline Geraldo Althoff & $\mathrm{SC}$ & PFL & Sim & Sim \\
\hline Geraldo Cândido & RJ & PT & Não & Não \\
\hline
\end{tabular}




\begin{tabular}{|c|c|c|c|c|}
\hline Geraldo Lessa & $\mathrm{AL}$ & PSDB & Ausente & Sim \\
\hline Geraldo Melo & $\mathrm{RN}$ & PSDB & Sim & Ausente \\
\hline Gerson Camata & ES & PMDB & Sim & Sim \\
\hline Gilberto Mestrinho & $\mathrm{AM}$ & PMDB & Sim & Sim \\
\hline Gilvam Borges & AP & PMDB & Sim & Sim \\
\hline Heloísa Helena & $\mathrm{AL}$ & PT & Não & Não \\
\hline Hugo Napoleão & PI & PFL & Sim & Sim \\
\hline Íris Rezende & GO & PMDB & Sim & Sim \\
\hline Jader Barbalho & PA & PMDB & Sim & Sim \\
\hline Jefferson Peres & AM & PDT & Não & Não \\
\hline João Alberto Souza & MA & PMDB & Sim & Não \\
\hline Jonas Pinheiro & MT & PFL & Ausente & Sim \\
\hline Jorge Bornhausem & $\mathrm{SC}$ & PFL & Sim & Sim \\
\hline José Agripino Maia & $\mathrm{RN}$ & PFL & Sim & Sim \\
\hline José Alencar & MG & PL & Sim & Sim \\
\hline José Eduardo Dutra & $\mathrm{SE}$ & PT & Não & Não \\
\hline José Fogaça & $\mathrm{RS}$ & PPS & Sim & Sim \\
\hline José Jorge & $\mathrm{PE}$ & PFL & Sim & Sim \\
\hline $\begin{array}{l}\text { José Roberto Arru- } \\
\text { da }\end{array}$ & $\mathrm{DF}$ & PSDB & Sim & Sim \\
\hline José Sarney & AP & PMDB & Ausente & Sim \\
\hline $\begin{array}{l}\text { Juvêncio da Fonse- } \\
\text { ca }\end{array}$ & MS & PSDB & Sim & Sim \\
\hline Lauro Campos & DF & PDT & Não & Não \\
\hline $\begin{array}{l}\text { Leomar Quintani- } \\
\text { lha }\end{array}$ & TO & PFL & Sim & Sim \\
\hline Lúcio Alcântara & $\mathrm{CE}$ & PSDB & Sim & Sim \\
\hline Lúdio Coelho & MS & PSDB & Sim & Sim \\
\hline Luiz Estevão & $\mathrm{DF}$ & PMDB & Sim & Sim \\
\hline Luiz Otávio & PA & PMDB & Sim & Sim \\
\hline Luiz Pontes & $\mathrm{CE}$ & PSDB & Sim & Sim \\
\hline Luzia Toledo & ES & PSDB & Sim & Sim \\
\hline Maguito Vilela & $\mathrm{GO}$ & PMDB & Ausente & Sim \\
\hline
\end{tabular}




\begin{tabular}{|c|c|c|c|c|}
\hline $\begin{array}{l}\text { Maria do Carmo } \\
\text { Alves }\end{array}$ & SE & PFL & Sim & Abstenção \\
\hline Marina Silva & $\mathrm{AC}$ & PT & Ausente & Não \\
\hline Marluce Pinto & RR & PMDB & Sim & Sim \\
\hline Mauro Miranda & GO & PMDB & Sim & Sim \\
\hline Moreira Mendes & RO & PFL & Sim & Ausente \\
\hline $\begin{array}{l}\text { Mozarildo Caval- } \\
\text { cante }\end{array}$ & $\mathrm{RR}$ & PTB & Ausente & Abstenção \\
\hline Nabor Júnior & $\mathrm{AC}$ & PMDB & Sim & Sim \\
\hline Ney Suassuna & $\mathrm{PB}$ & PMDB & Sim & Sim \\
\hline Osmar Dias & PR & PDT & Sim & Sim \\
\hline Paulo Hartung & ES & PSB & Sim & Sim \\
\hline Paulo Souto & $\mathrm{BA}$ & PFL & Sim & Sim \\
\hline Pedro Piva & SP & PSDB & Sim & Sim \\
\hline Pedro Simon & $\mathrm{RS}$ & PMDB & Sim & Sim \\
\hline Ramez Tebet & MS & PMDB & Sim & Sim \\
\hline Renan Calheiros & $\mathrm{AL}$ & PMDB & Sim & Sim \\
\hline Roberto Freire & $\mathrm{PE}$ & PPS & Ausente & Não \\
\hline Roberto Requião & PR & PMDB & Sim & Não \\
\hline Roberto Saturnino & $\mathrm{RJ}$ & PT & Não & Não \\
\hline Romero Jucá & RR & PSDB & Sim & Sim \\
\hline Romeu Tuma & SP & PFL & Sim & Sim \\
\hline $\begin{array}{l}\text { Ronaldo Cunha } \\
\text { Lima }\end{array}$ & PB & PSDB & Sim & Sim \\
\hline Sebastião Rocha & $\mathrm{AP}$ & PDT & Não & Não \\
\hline Sérgio Machado & $\mathrm{CE}$ & PMDB & $\mathrm{Sim}$ & Sim \\
\hline Tião Viana & $\mathrm{AC}$ & PT & Não & Não \\
\hline $\begin{array}{l}\text { Wellington } \\
\text { Roberto }\end{array}$ & PB & PTB & Sim & Sim \\
\hline
\end{tabular}

